Maria Helena Thomaz Maia

História seletiva e demográfica do MHC na América do Sul: um estudo de populações Nativas e Urbanas

Selective and demographic history of MHC in South America: a study of native and urban populations

São Paulo

2013 
Maria Helena Thomaz Maia

\section{História seletiva e demográfica do MHC na América do Sul: um estudo de populações Nativas e Urbanas}

Selective and demographic history of MHC in South America: a study of native and urban populations

Tese apresentada ao Instituto de Biociências da Universidade de São Paulo, para a obtenção de Título de Doutor em Ciências, na Área de Genética.

Orientador(a): Diogo Meyer

São Paulo 


\section{Ficha Catalográfica}

Maia, Maria Helena Thomaz

História seletiva e demográfica do MHC na América do Sul: um estudo de populações Nativas e Urbanas- 156 páginas

Tese (Doutorado) - Instituto de Biociências da Universidade de São Paulo. Departamento de Genética e Biologia Evolutiva.

1. MHC 2. Evolução 3.Seleção Recente I. Universidade de São Paulo. Instituto de Biociências. Departamento de Genética e Biologia Evolutiva.

\section{Comissão Julgadora:}


Dedico a luta dos povos do mundo todo, em especial,

à dos latino americanos, 
"Ainda que tenhamos alcançado vitórias extraordinariamente importantes, não há razão alguma para sermos arrogantes. A modéstia faz avançar; a arrogância, retroceder." Mao Tse-tung 


\section{Agradecimentos}

Agradeço a todos que direta ou indiretamente fizeram com que esses quatro anos valessem a pena em todos os sentidos. Que contribuíram para o meu crescimento pessoal e científico e que me ensinaram que ciência se faz com paixão, curiosidade, disciplina e principalmente, colaboração.

Mais especificamente gostaria de agradecer:

À Universidade de São Paulo, pela estrutura e condições de trabalho excelentes;

Ao CNPq e CAPES, pelas bolsas concedidas no país e no exterior.

À FAPESP pelo auxílio concedido para a execução do projeto.

Ao meu orientador, Diogo Meyer, que me ensinou a necessidade de sermos independentes e capazes de defender nossas ideias com unhas e dentes. Que muitas vezes cumpriu o papel de "advogado do diabo" para que pudéssemos sempre buscar melhores explicações para nossas questões, mas que me apoiou, incondicionalmente, no momento que mais precisei. Obrigada pela paciência e dedicação a minha formação.

Ao Prof. Jorge Rocha, pela sua ajuda imprescindível no entendimento da dinâmica de populações africana e miscigenadas, pelas nossas conversas intermináveis e pela companhia bestial em Portugal.

Ao Prof. Eduardo Santos, pelas amostras cedidas e pelas contribuições sempre valorosas, que nos ajudaram a dar um rumo melhor para as nossas questões.

À Prof ${ }^{a}$ Maria Luiza Petzl-Erler, pelas amostras cedidas e por suas contribuições para a discussão de diversidade de populações ameríndias.

À Dra Margareth Torre, coordenadora do LIG, que nos deu suporte para o sequenciamento, análise e discussão dos nossos resultados de genes HLA.

Ao Prof João Morgante, por ter me recebido de braços abertos no LABEC, e pelo carinho e atenção sempre constante.

Às meninas e menino do LIG: Tânia, Simone, Gê, Carlitos e Roberta. As tardes em Santa Cecília passavam rápido na companhia de vocês! 
A jornada que percorri nesses quatro anos, me deu varias famílias nos diversos lugares onde passei. Pessoas que me ajudaram e me receberam com carinho. Quero agradecê-las e, por favor, se eu me esqueci de alguém, perdoe-me! Perdi muitos neurônios nesse período também.

Aos meus amigos e família do Labec: Nádia, JuJu, Aninha, Fezinha, Anna Carolina, Helena, Gabriella, Billy Boy, Vanessa, Lary, Carol Aires, Felipe, Gigi, Camila, Sofia. Sem vocês, essa jornada não teria sido tão divertida e inesquecível. Obrigada pelo carinho, ombro amigo e por serem sempre tão companheiros.

Preciso agradecer em especial à menina Gigi, que pra mim, é um exemplo de determinação e luta. Tenho muita admiração por você e não tenho como te agradecer pela amizade e pelos anos que passamos juntas na nossa querida casinha.

Ao Grupo de Genética Evolutiva: Ramalho, Binho, Gustavo, Débora, Bárbara, Kelly, Marcia e Rodrigo Latino. Obrigada pelas discussões e contribuições, pela companhia e por dividirem o conhecimento de vocês comigo.

Em especial, preciso agradecer a alguns integrantes desse grupo:

À Kelly, pela ajuda no final da tese e durante o desenvolvimento dos projetos. Sem sua contribuição, o caminho teria sido muito mais longo!

A minha querida Duty, sempre uma companhia agradável, curiosa e apaixonada. Obrigada pelo carinho e amizade!

À Mano Pincerati! Por me acolher e me ajudar fase de transição para São Paulo. Também não tenho como agradecer sua amizade e carinho. Obrigada por não deixar a peteca cair e sempre estar disposta a ajudar. Quero que vc saiba que: É NOIS, Mano!

Como não poderia deixar de ser, preciso agradecer de maneira mais do que especial ao meu irmão, Rodrigo "Latino" dos Santos Francisco. Berenice, segura! Nós vamos bater! (Lopes, Leila \& La Monica, Berenice, 1999). Meu companheirão, que sempre esteve disposto a conversar (o que às vezes era um problema...) e discutir sobre qualquer coisa, da fenda do peptídeo ao Arrebatamento. Muito obrigada, por tudo e Vamo Arrasá!!

À minha família do LGHM, tanto a new quanto a old generation: Leleco, Dudu, Janoca, Lay, Yuka, Lary (+Kimani), Lilian (+João), Paloma (+Arthur), Clayton, Milena, 
Dafne, Andrea, Bruna e Ana Paula, por ainda me considerarem da casa e por todo o apoio que me deram pra que eu viesse fazer o doutorado. Nunca vou esquecer a nossa despedida! Mas eu to voltando!

Ao Bruninho, meu irmão porto-paraense, que me recebeu tão bem e fez com que eu me sentisse em Belém, todos os dias, mesmo estando do outro lado do atlântico, na maravilhosa Vila do Conde. Aproveito e agradeço a minha família portuguesa: Claudia e Ricardo (+Iris), que estiveram presentes sempre! Aos Ribeiro Vila Real, que me mostraram o real sentido de uma casa portuguesa, com certeza!

À todos os que trabalharam comigo no CTM-CIBIO-Porto: Guilherme, Soraya, Javier, Jolita, Diana, Teresa, Sarita João e Susana e todos os outros que la passaram, de diferentes lugares do mundo. Obrigada por me aguentarem imitando Amália Rodrigues! Em especial, agradeço à Susana, por todo o suporte nas análises com o microssatélites e por me ensinar as técnicas ninjas dos PCRs multiplexs com cauda M13!

Mas em especial, agradeço à linda Dorinha, por seu exemplo e perseverança e por ter me recebido como se fosse sua irmã! Torço muito pelo seu sucesso!

Aos meus amigos de Belém, que não me deixaram perder o foco e que me ajudaram a manter sempre desobstruída a visão dos meus objetivos. Avante, sempre!

A minha família agregada: Chenia, Luiz, Raquel e Tata, por engrossarem o caldo da torcida!

À minha família, Ana Luiza, Fabíola e Pedro por estarem sempre ao meu lado, em todos os momentos. Somos um exemplo de que juntos, podemos superar as maiores dificuldades. Obrigada, especialmente a minha mãe, pela batalha que travou praticamente sozinha, para que nós três tivéssemos um futuro melhor.

Ao Berio, meu porto seguro. Agradeço pelo amor incondicional, pelo companheirismo e amizade, além da paciência de jó! Sem a tua ajuda e apoio, eu não teria conseguido. Amo-te.

A todos que direta e indiretamente ajudaram nessa jornada, mas que não foram citados, MUITO OBRIGADA! 


\section{Sumário}

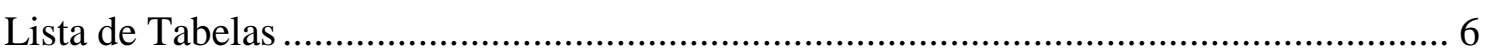

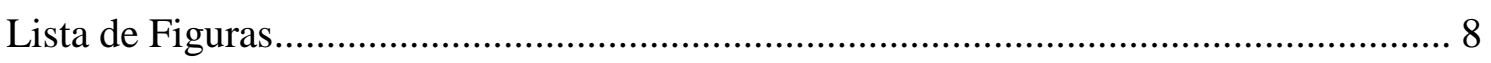

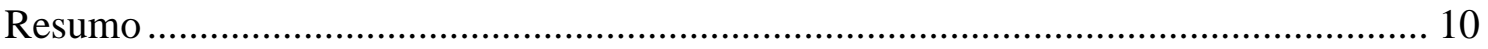

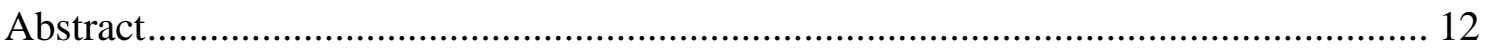

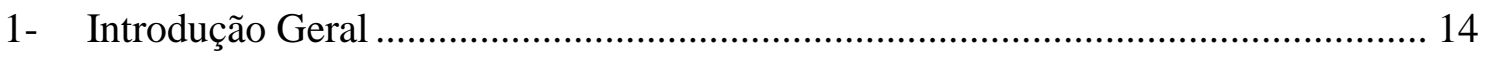

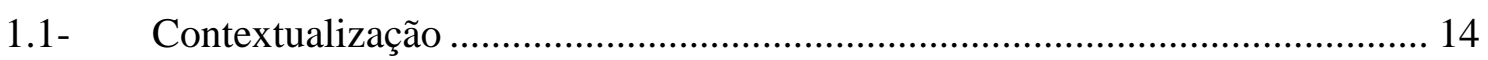

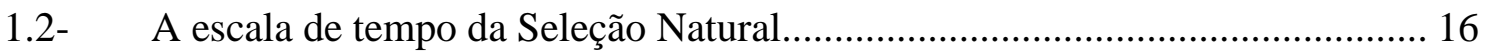

1.3- Complexo Principal de Histocompatilibildade (MHC) ............................ 18

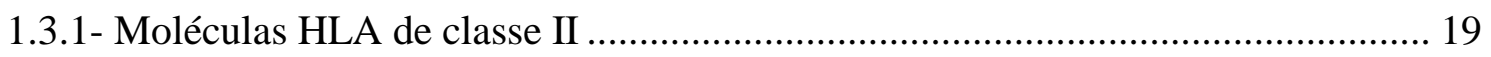

1.3.2- Variabilidade e evidências de Seleção Natural ................................................... 21

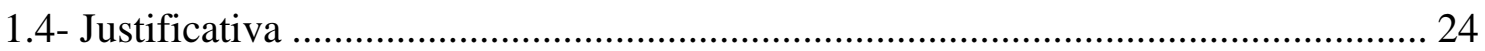

Capítulo 1. Evolução dos genes HLA de classe II no contexto das populações nativas da

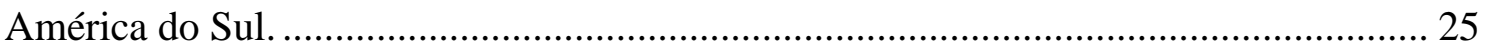

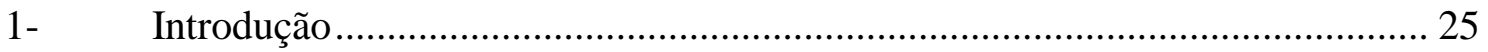

1.1- Modelo de povoamento do Continente Americano .................................. 26

1.2- Caracterização da diferenciação populacional na América do Sul....... 27

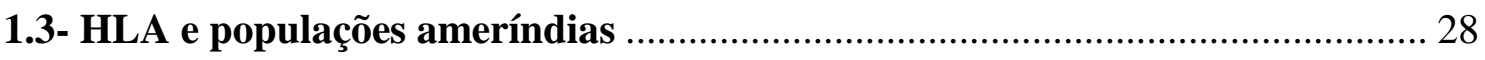

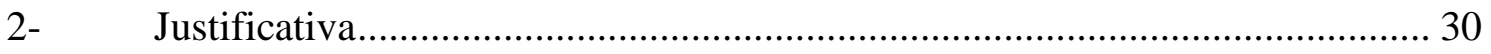

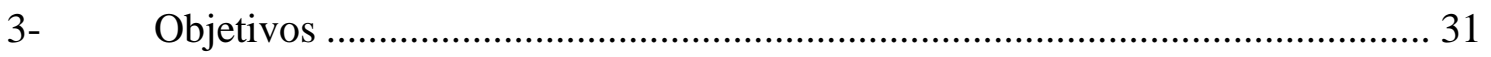

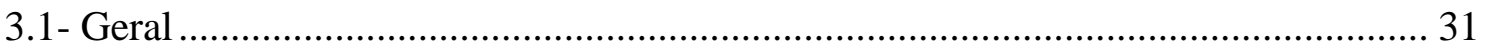

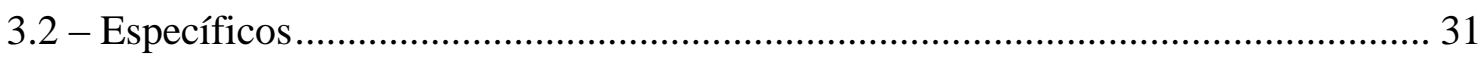


4- Material e Métodos

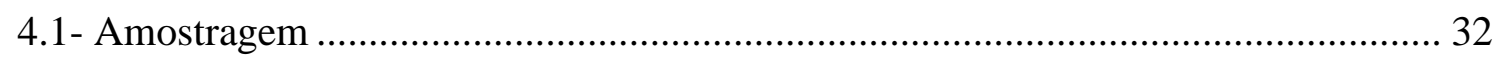

4.1.1- Indivíduos genotipados para genes HLA de classe II clássicos.......................... 32

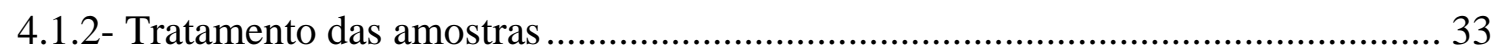

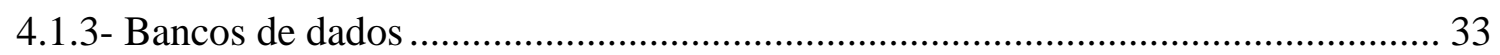

4.2- Amplificação, sequenciamento e genotipagem do exon 2 dos genes HLA de classe

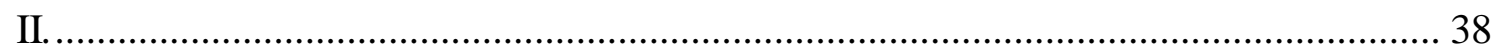

4.3- Edição de sequências e determinação dos haplótipos e alelos de HLA .................. 42

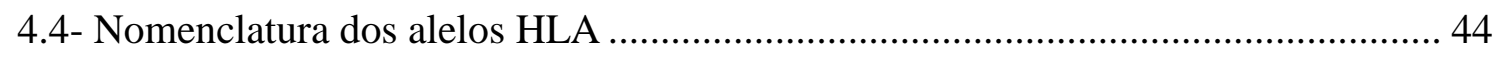

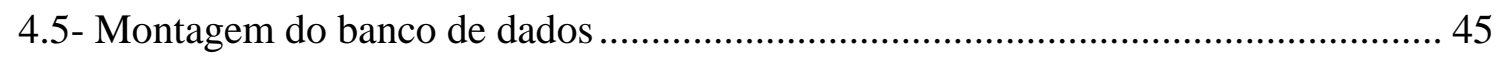

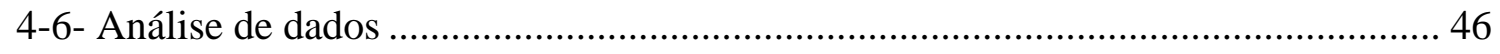

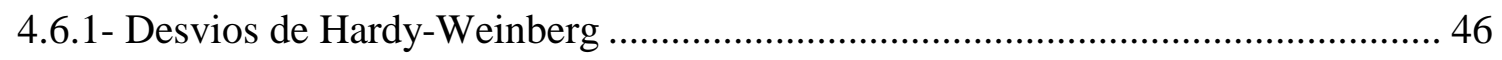

4.6.2- Determinação de alelos restritos e com frequência entre as Américas e outras

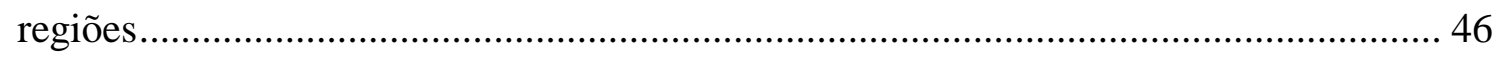

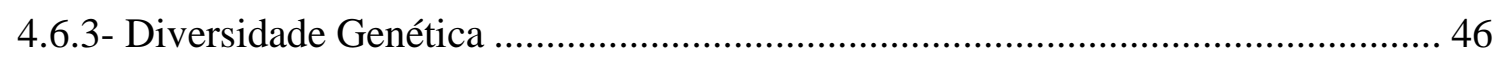

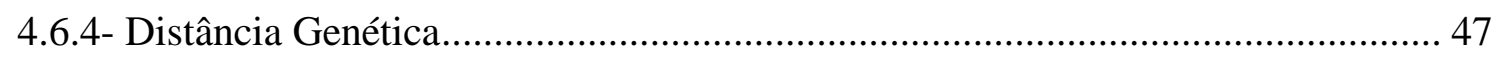

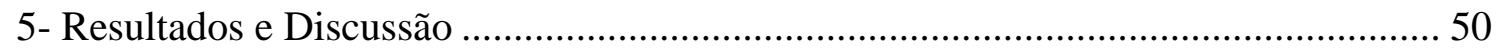

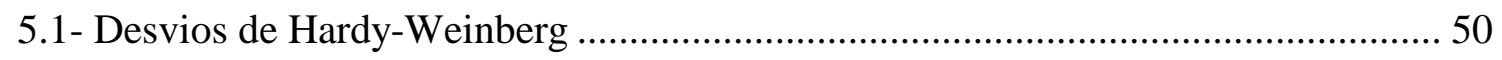

5.2- Diversidade e Distribuição Geográfica dos Alelos .............................................. 50

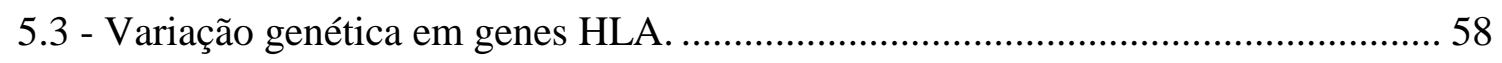

5.4- Relação entre He em genes HLA e em microssatélites ......................................... 60

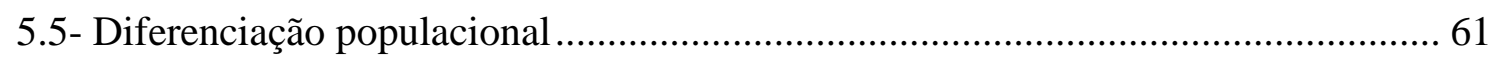

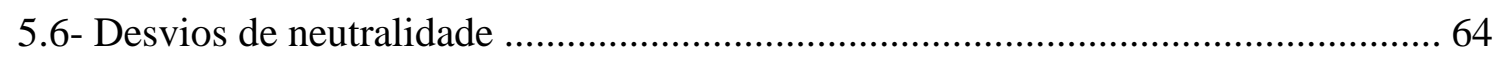


Capitulo 2. Investigação de sinais seleção recente nas proporções de ancestralidade do MHC da população miscigenada de Belém

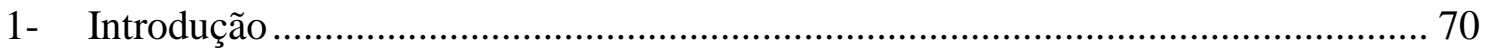

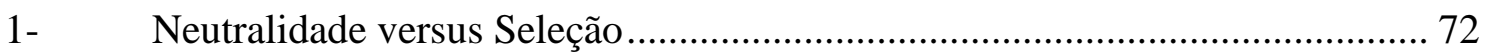

2- $\quad$ Formação da população de Belém............................................................ 74

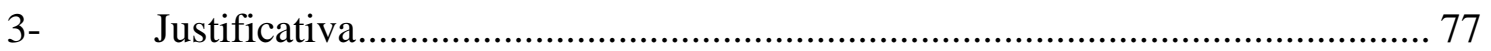

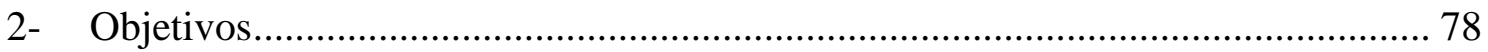

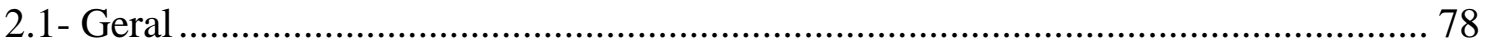

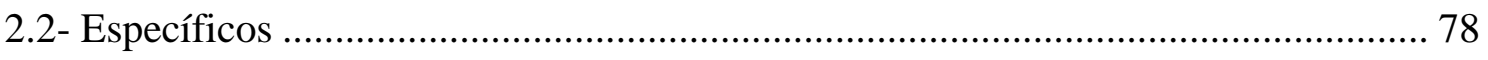

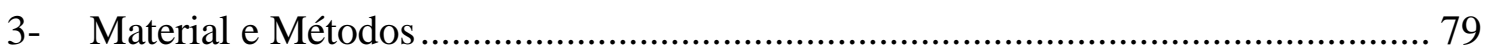

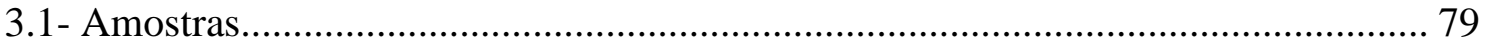

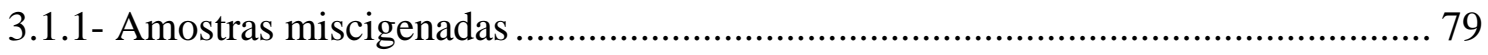

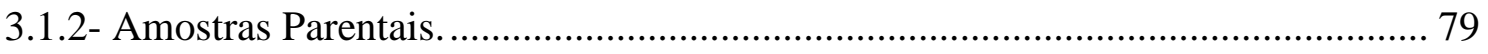

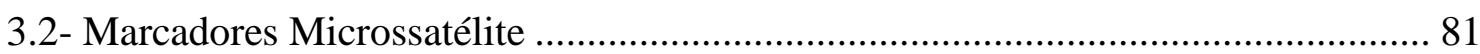

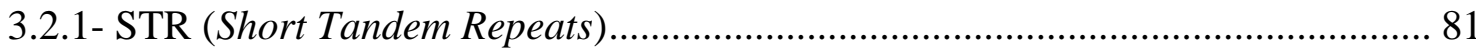

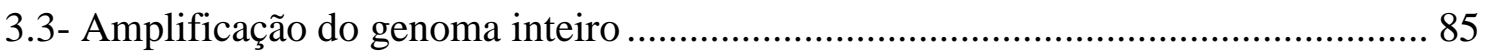

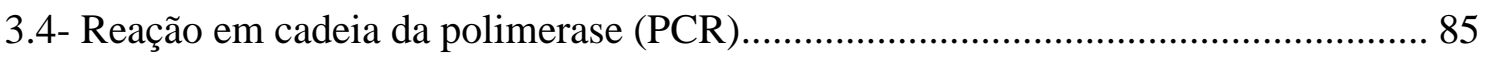

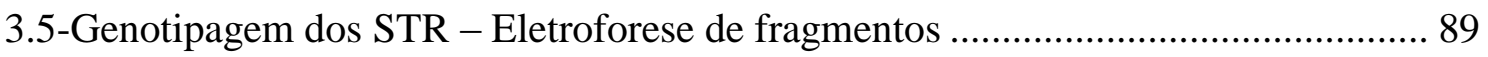

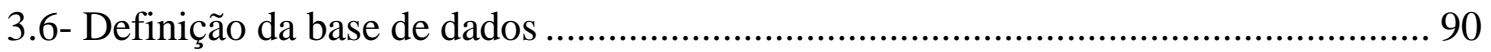

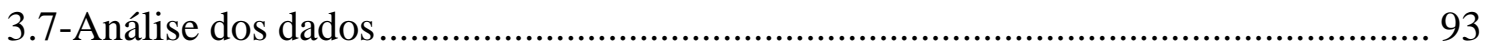

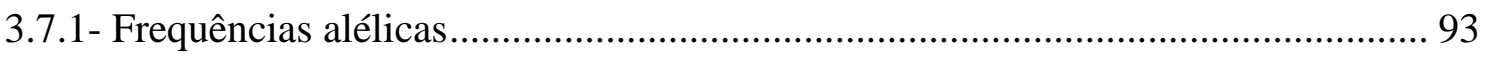

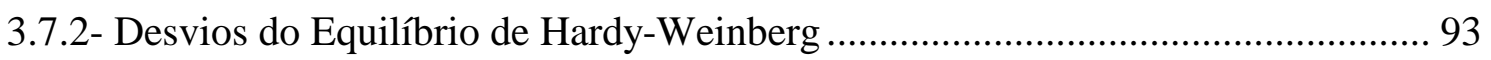

3.7.3- Descrição da variabilidade genética ..................................................................... 93 
3.7.4- Estimativa de ancestralidade 93

3.7.5- Validação dos STR Genômicos como estimadores de ancestralidades. 94

3.7.6- Diferenciação populacional 95

3.7.7- Comparação das proporções de ancestralidade 97

4-Resultados 98

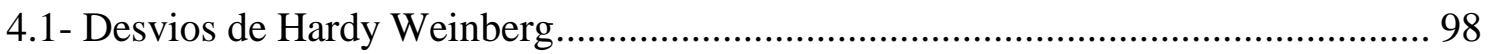

4.2- Índices de Diversidade 100

4.3-Validação dos STR com estimadores de ancestralidade 104

4.4-Análise de ancestralidade 105

4.5-Correlação entre proporções de ancestralidade no Genoma e MHC 107

4.6-Diferenciação populacional 108

5 -Discussão. 110

5.1-Desvios de Hardy-Weinberg 111

5.1.1-Influência dos marcadores com desvios de Hardy-Weinberg 111

5.1.2- Influência da amalgamação de populações

5.2-Influência do desequilíbrio de ligação entre os STR

5.3- Análises para validação dos resultados 114

5.4- Diversidade genética 114

5.5- Estimativas de Ancestralidade 116

5.5.1-Estimativas de ancestralidade genômica 116

5.5.2-Desvios de ancestralidade entre o MHC e a média genômica. 118

5.6- Hipótese seletiva 119 
5.6.1- Seleção Natural no MHC ....

120

6- Discussão Geral e Conclusões.

7 - Referências Bibliográficas

Apêndice . 135 


\section{Lista de Tabelas}

Tabela.1 Localização, grupo linguístico e tamanho amostras das populações estudadas $\quad 27$

Tabela.2 Descrição, localização, fonte de obtenção e tamanho das amostras utilizadas no presente estudo 31

Tabela.3 Sequencia de oligonucleotideos inciadores utilizados na amplificação e sequenciamento do exon dos dos loci HLA-DRB1, -DQB1 e-DPB1 33

Tabela.4 Concentração dos reagentes 35

Tabela.5 Condições de temperatura $\quad 37$

Tabela.6 Frequências alélicas de HLA-DRB, -DQB1 e-DPB1 nas populações da América do Sul $\quad 46$

Tabela.7 Alelos de HLA-DRB1 observados entre Ameríndios49

Tabela.8 Alelos de HLA-DQB1 observados entre Ameríndios50

Tabela.9 Alelos de HLA-DPB1 observados entre Ameríndios 50

Tabela.10 Estimativas de diferenciação populacional para os 61 STR genômicos e os três genes de classe II estudados 57

Tabela.11 Valores de D de Tajima para as populações do Leste da América do Sul 60

Tabela.12 Descrição das amostras utilizadas no presente estudo e tamanho amostral 77

Tabela.13 Lista dos 67 STR genômicos usados no projeto, com informações sobre a localização no genoma, nome do lócus, nome e tipo do marcador. 78

Tabela.14 Lista dos 10 STR do MHC utilizados com informações sobre o tipo de unidade de repetição. 80 
Tabela.15 Reação de genotipagem dos STR: informações sobre conjunto de multiplexagem, e concentração dos oligonucleotídeos iniciadores dos STR-USP multiplexados. 82

Tabela.16 Reação de genotipagem dos STR: informações sobre conjunto de multiplexagem, e concentração dos oligonucleotídeos dos STR-UP multiplexados. 83

Tabela.17 Informação sobre os STR do MHC, reação de PCR e os agrupamentos para eletroforese. $\quad 85$

Tabela.18 STR utilizados nas análises após a depuração dos dados. $\quad 87$

Tabela.19 Marcadores que apresentaram desvios de Hardy-Weinberg nas diferentes populações. 95

Tabela.20 Média dos índices de diversidade genética e Delta para os STR Genômicos e do MHC 97

Tabela.21 Média das ancestralidades estimadas na amostra de Belém por STR Genômicos, MHC e INDEL. 101

Tabela.22 Valores de FST para os pares de populações e o deltaFST obtido pela diferença entre o FST genômicos e FST do MHC 104

Tabela.23 Estimativas de ancestralidade para Belém em diferentes estudos 113 


\section{Lista de Figuras}

Figura.1 Mapa da região do MHC no cromossomo 613

Figura.2 Representação do processamento e apresentação do peptídeo antigênicos pelas moléculas HLA 14

Figura.3 Moléculas do MHC de classe II 15

Figura.4 Mapa com a localização das populações utilizadas neste estudo 30

Figura.5 Layout do programa Sequecher ${ }^{\circledR} \quad 38$

Figura.6 Página Inicial da ferramenta SBT 39

Figura.7 Nomenclatura dos alelos de genes HLA 40

Figura.8 Eliminação de posições sinônimas em grupos de alelos $\quad 41$

Figura.9 Box Plot das taxas de heterozigose 55

Figura.10 Correlação entre a taxa de heterozigose esperada de STR genômicos e genes HLA de classe II 56

Figura.11 Correlação entre os FST par a par obtidos para os STR genômicos e genes HLA de classe II nas populações do Leste da América do Sul59

Figura.12 Box Plot do valores de D de Tajima para as populações da America do sul versus populações do resto do mundo 61

Figura.13 Correlação entre os valores de D de Tajima, estimados pelos genes HLA de classe II, e Diferenciação ß, estimada para os microssatélites genômicos

Figura.14 Localização dos STR ao na região do MHC 81

Figura.15 Gráficos de correlação das proporções de ancestralidade obtidas pelo banco de dados com marcadores desviados para as proporções de Hardy-Weinberg 96 
Figura.16 Índices de diversidade genética para cada STR Genômico e a média nas populações parentais e na população miscigenada de Belém 98

Figura.17 Índices de diversidade genética para cada STR do MHC e os valores médios nas populações parentais e na população miscigenada de Belém. 99

Figura.18 Gráficos de correlação das proporções de ancestralidade africana, europeia e ameríndia estimadas por INDELs e os STR genômicos 100

Figura.19 Representação gráfica das proporções individuais de ancestralidade na população de Belém 102

Figura.20 Box Plot dos valores de ancestralidade individuais 102

Figura.21 Teste de de aleatorização de valores de deltaFST. 105 


\section{Resumo}

Um dos maiores desafios em estudos de genética de populações é a diferenciação entre os sinais de diversidade genética resultantes de efeitos estocásticos dos sinais de seleção natural. Neste trabalho, o objetivo central foi inferir a história evolutiva, em termos de demografia e seleção natural, do MHC e alguns de seus genes $H L A$ de classe II (HLA-DRB1, $-D Q B 1$ e $-D P B 1)$. A primeira estratégia usada foi sequenciar os referidos genes em 14 populações ameríndias e, em conjunto com dados já publicados em outras populações ameríndias e não ameríndias, contrastou-se sua distribuição de alelos, diversidade genética intra e interpopulacional e testes de neutralidade com as mesmas estatísticas obtidas a partir de 54 STR genômicos genotipados para estas mesmas populações.

Em nossos resultados verificamos: a) a maior variabilidade dos genes $H L A$ em relação aos STR, b) a menor variabilidade de ameríndios se comparados com não ameríndios e c) correlação das estimativas de $\mathrm{F}_{\mathrm{ST}}$ obtidas de STR com as obtidas dos genes $H L A$. Esses resultados indicam a ação da demografia como principal responsável pelos padrões encontrados. No entanto, outras evidências sugerem um padrão de diversidade genética que não pode ser explicado por mera ação do acaso, como por exemplo: a) o grande número e dispersão geográfica de alelos privados e/ou mais prevalentes em ameríndios (vinte vezes mais frequentes) para $H L A-D R B 1$, b) a não correlação das estimativas de diversidade genética intrapopulacional obtidas de genes HLA com as obtidas de STR, c) os maiores valores de $\mathrm{F}_{\mathrm{ST}}$ para genes $H L A$ em comparação com o $\mathrm{F}_{\mathrm{ST}}$ de STR e a d) ausência de correlação dos valores de D de Tajima (para $H L A$ ) com a estimativa $\beta$ (para STR). Assim, apesar da grande influência de fatores estocásticos, os sinais de seleção natural são perceptíveis. 
A segunda abordagem investigou sinais de seleção recente na região do MHC na população miscigenada de Belém do Pará $(n=202)$, utilizando como ferramenta a comparação entre os componentes de ancestralidade estimados para a região do MHC (com sete STR) com os observados no restante do genoma (54 STR) para detecção de desvios na ancestralidade das populações parentais. As proporções de ancestralidade média para os STR em Belém (africana=0,19, europeia=0,51 e ameríndia=0,30), foram diferentes das estimadas para os marcadores do MHC (africana $=0,23$, europeia $=0,67 \mathrm{e}$ ameríndia $=0,11$, sendo as diferenças entre as estimativas ameríndia e europeia significativa (Wilcoxon; $\mathrm{p}<0,0001$ ). Além disso, os valores de $\mathrm{F}_{\mathrm{ST}}$ observados eram maiores entre Belém e Ameríndios, considerando-se os STR do MHC. É possível concluir, portanto, que foi observada uma perda de componente genético ameríndio na região do MHC durante o processo de miscigenação, quando contrastarmos com as estimativas genômicas, sugerindo ação de seleção natural recente.

Em conjunto, nossos resultados mostram que tanto a seleção natural como a demografia moldaram a variação genética em genes HLA, e que usando métodos apropriados, incluindo o mapeamento por miscigenação, eventos de seleção natural que ocorreram em escalas de tempo recentes podem ser detectados. 


\section{Abstract}

One of the greatest challenges on the Genetics Populations Studies is the differentiation among the resulting genetic signs of diversity from the stochastic signs of natural selection. On the present study, the main objective was inferring the evolutive history, in terms of demography and natural selection, from the MHC and some of its $H L A$ class II genes (HLA-DRB1, -DQB1 $e-D P B 1)$. The first strategy used was sequentiating the referred genes in 14 Amerindian populations and, in conjunction with data already published in other Amerindian and non-Amerindian populations, we have contrasted its distribution in alleles, intra and interpopulational genetic diversity and neutrality tests with the same statistics obtained from 54 STR genomics genotyped for these same populations.

In our results we have verified: a) greater variability of the $H L A$ genes in relation to the STR, b) greater variability of Amerindians, if compared to nonAmerindians and c) correlation of the estimates of $F_{S T}$ obtained from STR with the ones obtained from the HLA genes. These results indicate the demography action as the main responsible for the found patterns. However, other evidences suggest a pattern of genetic diversity that can't be explained only by chance, as for example: a) the great number and geographic dispersion of the private alleles and/or more prevalent in the Amerindians (twenty times more frequent) for $H L A-D R B 1, \mathrm{~b}$ ) a noncorrelation of the estimates on interpopulational genetic diversity obtained from $H L A$ genes with the ones obtained from STR, c) greater values of $\mathrm{F}_{\mathrm{ST}}$ for the $H L A$ genes, in comparison with the $\mathrm{F}_{\mathrm{ST}}$ of STR and d) absence of correlation on the D values of Tajima (for $H L A$ ) with $\beta$ estimates (for STR). So, despite the great influence of stochastic factors, the signs of natural selection are perceptible. 
The second approach investigated signs of recent selection in the MHC region of the admixture population of Belém do Pará $(n=202)$, using as tool the comparison between the ancestrality components estimated for the MHC region (with seven STR) with the ones observed on the remaining genome (54 STR) for the detection of deviations on the ancestrality of the parental populations. The medium ancestrality proportions for the STR in Belém (African=0,19, European=0,51 and Amerindian=0,30), was different from the estimates for the MHC markers (African=0,23, European=0,67 and Amerindian=0,11), being significative the differences between Amerindian and European estimates (Wilcoxon; p<0,0001). Furthermore, the $\mathrm{F}_{\mathrm{ST}}$ values observed were greater between Belém and the Amerindians, considering the STR from the MHC. It's then possible to get to the conclusion that a loss in Amerindian genetic component was observed in the MHC region during the miscegenation process, when contrasted with the genomic estimates, suggesting recent action of natural selection.

In whole, our data show that even natural selection as demography have molded the genetic variation in the HLA genes, and by using the appropriated methods, including the miscegenation mapping, natural selection events occurred in recent time scales can be detected. 


\section{1- Introdução Geral}

\section{1- Contextualização}

A seleção natural pode mudar a composição genética de populações. Isso ocorre, por exemplo, quando certas variantes alélicas aumentam as chances de sobrevivência e reprodução de seus portadores, e tornam-se mais comuns naquela população. Se diferentes populações sofrem seleção natural que favorece variantes diferentes para um determinado gene, elas se tornarão diferentes naquela região do genoma (Akey et al., 2004). O maior desafio para detectar regiões genômicas com diferenciação causada pela seleção natural é distinguir que proporção da diferenciação genética deve-se a efeitos aleatórios, associados à deriva genética, e qual pode ser atribuída à ação da seleção natural. Uma abordagem comumente utilizada consiste em comparar o grau de diferenciação genética de um gene em relação àquela esperada apenas sob deriva, algo que pode ser obtido usando simulações (Hofer, Foll, \& Excoffier, 2012) ou comparando genes candidatos com a diferenciação vista no restante do genoma (Akey, 2009)

Neste trabalho, o objetivo central foi analisar a história evolutiva de genes HLA em populações nativas e urbanas das Américas, com foco na América do Sul. Ainda que existam abundantes evidências de que a seleção natural atua sobre genes HLA, há importantes questões que permanecem em aberto e que serão o foco de nossa atenção. Essas incluem a compreensão da escala de tempo da ação da seleção natural (incluindo a investigação a respeito da existência de seleção em escalas de tempo recente e remoto), e o papel relativo de processos demográficos e seletivos sobre esses genes. Nosso estudo 
emprega duas abordagens distintas, informativas sobre seleção natural em diferentes escalas de tempo na história de populações nativo-americanas.

a- A primeira abordagem consiste em examinar a história evolutiva de populações nativo-americanas do sul a partir da diversidade genética dos genes codificantes dos Antígenos Leucocitários Humanos de classe II (HLAsigla do termo em inglês Human Leukocyte Antigen), localizados no Complexo Principal de Histocompatibilidade (MHC- sigla do termo em Major Histocompatibility Complex);

b- A segunda abordagem teve como foco investigar sinais de seleção recente na região do MHC em uma população miscigenada (população trihíbrida de Belém do Pará), utilizando como ferramenta a comparação entre os componentes de ancestralidade estimados para a região do $\mathrm{MHC}$ com os observados no restante do genoma.

Para isso, este estudo inicia com uma introdução geral, que aborda questões centrais sobre as formas de detecção e seleção natural em diferentes escalas de tempo, além das características fundamentais sobre a diversidade e evolução dos genes HLA, que são o foco das questões evolutivas deste trabalho. 


\section{2- A escala de tempo da Seleção Natural}

A diversidade genética dentro e entre populações é determinada por sua história demográfica e seletiva. Um dos maiores desafios da pesquisa em genética evolutiva tem sido compreender o quanto da diversidade genética é resultante do acúmulo passivo de mutações sem efeitos seletivos e o quanto resulta da seleção natural atuando sobre mutações que alteram a aptidão de indivíduo.

Nos últimos anos, a geração de dados em escala genômica favoreceu o desenvolvimento de linhas investigativas que contribuíram para o entendimento sobre o papel desses processos micro-evolutivos, na variabilidade e na diferenciação genética de populações humanas.

A identificação de genes que tenham sido selecionados positivamente foi o foco de diversos estudos (Voight et al. 2006, Barreiro et al. 2008, Coop et al. 2008, Fumagalli et al. 2011), sendo que a maioria deles é desenvolvida a partir de duas abordagens clássicas: a) escolha de genes candidatos a estarem sob seleção para então empregar uma analise populacional com o objetivo de compreender como a seleção está agindo (Akey et al., 2004) ; b) varredura genômica buscando a identificação de sinais de seleção em regiões ou genes. (revisado Nielsen et al. 2005).

Os métodos para detecção de eventos seletivos mais antigos envolvem a identificação de polimorfismos trans-específicos (escala de tempo na ordem de até sete milhões de anos); taxa de mutação sinônima maior do que não sinônima (um milhão de anos); diversidade nucleotídica (teste D Tajima, até 250 mil de anos); desequilíbrio de 
ligação (até 30 mil anos) (revisão em Garrigan \& Hedrick, 2003 e Bamshad \& Wooding, 2003).

Com relação à escala de tempo mais recente (isto é, seleção que moldou frequências alélicas nas últimas centenas de anos) as abordagens são mais restritas e resumem-se à detecção de regiões com redução de diversidade ao redor de variantes selecionadas (Pardis C Sabeti et al., 2002), (Rasmus Nielsen et al., 2009), assim como a de regiões com diferenciação genética extrema entre populações.

Mais recentemente foram desenvolvidos métodos que permitem a detecção de sinais de seleção recente a partir de dados de populações miscigenadas. Essa abordagem consiste na comparação das proporções de ancestralidade observadas em regiões supostamente neutras com regiões que estejam sob seleção (Long, 1991). Espera-se que as regiões genômicas sob seleção apresentem um desvio nas proporções de ancestralidade quando comparados com o restante do genoma (Tang et al., 2007), (Basu et al., 2008) caso a variante selecionada na população tenha proporções diferentes nas populações ancestrais.

Dentre os genes que mostraram evidências de seleção nos diversos estudos com diferentes abordagens de escala de tempo são os do sistema imune, que aparecem como sendo alvos da atuação de seleção balanceadora (Austin L Hughes, Packer, Welch, Chanock, \& Yeager, 2005). Os mais conhecidos são os genes HLA do Complexo Principal de Histocompatibilidade (MHC) (Austin L Hughes et al., 2005), (D Meyer \& Thomson, 2001).

Em função da importância desses genes para os dois estudos que realizamos, a seguir apresentamos uma revisão da função e variabilidade genética desses genes. 


\section{3- Complexo Principal de Histocompatilibildade (MHC)}

O MHC ocupa, aproximadamente, quatro milhões de pares de base (pb) no braço curto do cromossomo 6 em humanos (6p21.3) possuindo, em média, 1 gene a cada 16kb (CONSORTIUM 1999; MARTIN et al. 1998). Nesta região estão localizados mais de 200 genes, dos quais pelo menos $40 \%$ estejam envolvidos com o sistema imune (Consortium, 1999). Os antígenos leucocitários humanos (HLA) são os produtos gênicos mais conhecidos do MHC de nossa espécie e podem ser encontrados na membrana de todas as células nucleadas do organismo (SNUSTAD e SIMMONS 2001). Sua função é a de apresentar antígenos processados pelas células aos linfócitos T, como parte do mecanismo do sistema imune para a identificação e resposta a antígenos estranhos (STERN et al. 1994; SNUSTAD e SIMMONS 2001).

Tradicionalmente, o MHC é subdividido em três regiões: classes I, II e III. As regiões I e II contêm genes HLA e não-HLA (ou seja, genes que não codificam proteínas apresentadoras de antígenos), enquanto que a região de classe III contém apenas genes não-HLA (Parham, 2001) (Figura 01)

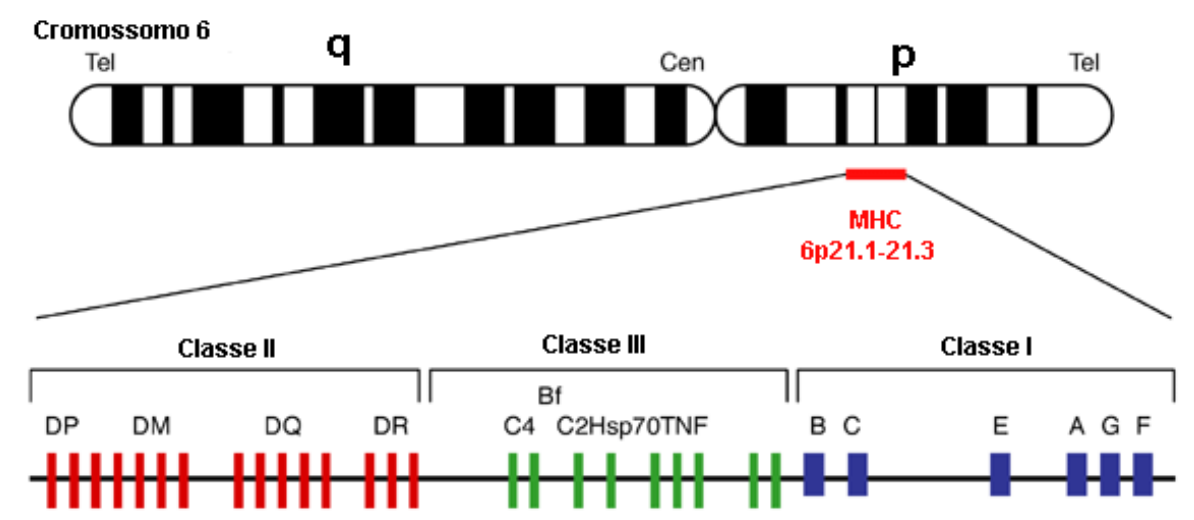

Figura.01: Mapa da região do MHC no cromossomo 6 (Modificado de http://www-ermm.cbcu.cam.ac.uk/03005969h.htm). 


\subsection{1- Moléculas HLA de classe II}

Os genes do MHC de classe II são constitutivamente expressos em células apresentadoras de antígeno (APC) e células B ativadas (Watts 1997, Varney, Gavrilidis, and Tait 1999) Sua função é apresentar peptídeos processados pela via exógena (figura 02) nas APC (ou seja, proteínas que são processadas no interior das células, mas que foram endocitadas) aos linfócitos $\mathrm{T}$ helper $\mathrm{CD} 4+$, que após o reconhecimento do antígeno, tornam-se ativados e iniciam a expansão clonal e o desenvolvimento de suas funções efetoras (Varney et al., 1999).

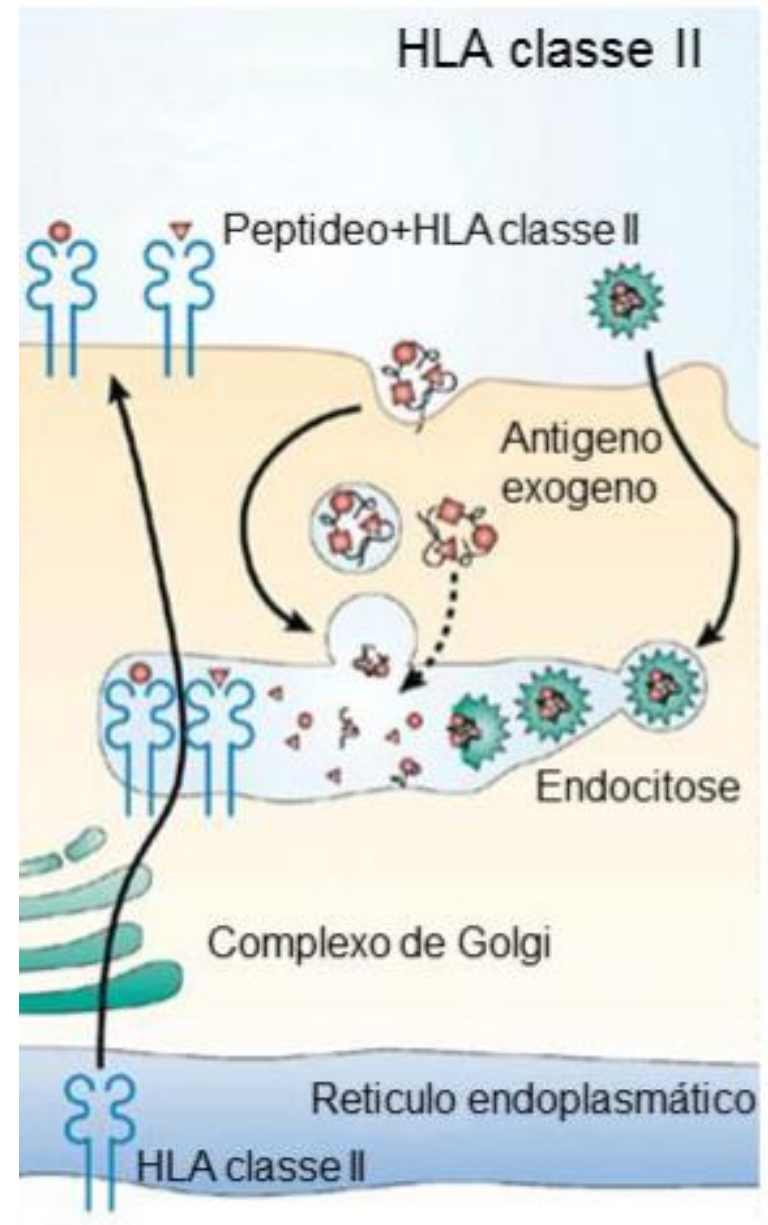

Figura 02- Representação do processamento e apresentação do peptídeo antigênicos pelas moléculas HLA. Na via de processamento de antígenos para 
apresentação por HLA de classe II, os antígenos exógenos são fagocitados pela célula e empacotados em vesícula fagocitária onde serão lisados. As moléculas HLA de classe II saem do reticulo endoplasmático e vão até as vesículas fagocitárias onde ligam-se aos peptídeos. As vesículas contendo HLA+pepdtideo fundem-se a membrana plasmática e as moléculas de HLA de classe II apresentam os peptídeos que são reconhecidos por linfócitos T CD4. Fonte: modificado de Villadangos e Schnorrer (2007)

Cada molécula de HLA de classe II é formada por duas cadeias polipeptídicas: $\alpha$ e $\beta$ (cada uma codificada por um gene diferente - ex: o gene HLA-DRB1 codifica a cadeia $\beta$ e HLA-DRA codifica a cadeia $\alpha$ de uma mesma molécula HLA), com dois domínios cada: $\alpha 1, \alpha 2 ; \beta 1, \beta 2$. Os domínios $\alpha 1$ e $\beta 1$ formam a fenda apresentadora de peptídeo (PBR- peptide-binding region), com capacidade para ligar antígenos que variam de 10 a 30 resíduos de aminoácidos. Os peptídeos que se ligam às moléculas de HLA possuem resíduos de aminoácidos chamados de "âncora", que interagem com o “chão" da fenda, que, por sua vez, contém um conjunto específico de aminoácidos que formam o sítio de reconhecimento de antígenos (ARS- antigen recognition site) (MEYER e THOMSON 2001). (Figura 03) 


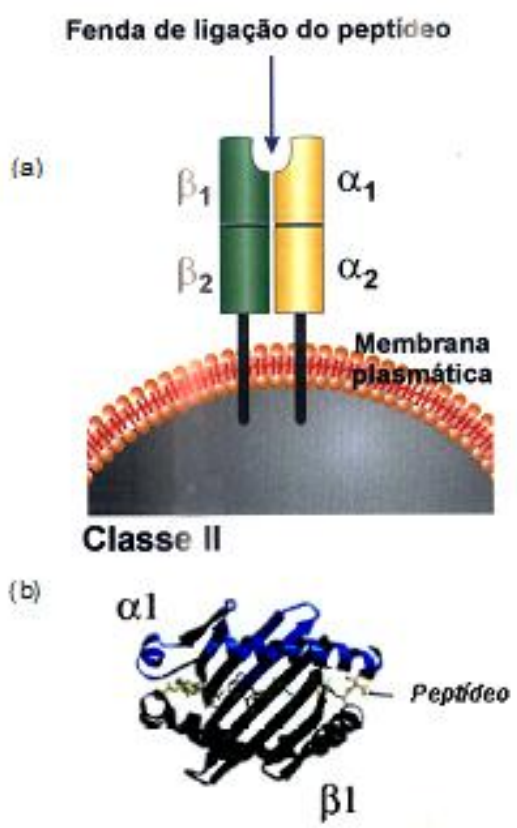

Figura 03: Moléculas do MHC de classe II. (a) estrutura da molécula; (b) fenda apresentadora de peptídeo (modificada de Abbas et al, 2000).

Os genes HLA de classe II são: $H L A-D R B$ (os expressos são $H L A-D R B 1,-D R B 3$, -DRB4, -DRB5 e -DRB6) e HLA-DRA, cujas cadeias $\beta$ e $\alpha$ formam a molécula HLA-DR; $H L A-D P A 1$ e $-D P B 1$ que formam a molécula HLA-DP; e HLA-DQA1 e -DPB1 que codificam os peptídeos que formam a molécula HLA-DP (MHC sequencing consortium, 1999; ABBAS 2000).

\subsection{2- Variabilidade e evidências de Seleção Natural}

Os genes que codificam para as moléculas HLA possuem um alto grau de variabilidade, e a explicação para a manutenção dessa diversidade envolve várias hipóteses seletivas. Uma delas é a de vantagem de heterozigoto ou sobre dominância. 
Essa hipótese foi motivada pela compreensão da função dos genes HLA, estabelecida por Zinkernagel \& Doherty, em 1974quando descreveram o fenômeno de restrição, que determina que as células $\mathrm{T}(\mathrm{CD} 4+$ ou $\mathrm{CD} 8+)$ só poderiam reconhecer peptídeos virais caso estivessem ligados a moléculas MHC na superfície de células (ZINKERNAGEL and DOHERTY 1974).

Baseados nessa descoberta, os mesmos autores, em 1975, desenvolveram uma explicação para a variabilidade desses genes: como combinações específicas de peptídeo com HLA são requeridas para ativar o sistema imune, os heterozigotos para loci MHC teriam uma capacidade maior do que homozigotos de iniciar uma resposta imune, pois teriam capacidade de apresentar um maior número de de peptídeos para o sistema imune (DOHERTY e ZINKERNAGEL 1975).

Outra hipótese capaz de explicar a variabilidade desses genes é a seleção dependente de frequência. Segundo esse modelo seletivo alelos, raros conferem vantagem seletiva para os indivíduos, enquanto que alelos muito comuns são menos vantajosos seletivamente. A lógica evolutiva para essa ideia é a de que patógenos estariam menos adaptados para escapar da apresentação por moléculas MHC raras, aos quais não teriam sido expostos e para os quais não teriam sido selecionadas mutações de escape (aquelas que alteram o patógeno de um modo que resulta na não apresentação do peptídeo). Os portadores dessas moléculas teriam vantagem seletiva sobre os outros e aumentariam de frequência progressivamente. Na medida em essas variantes se tornassem mais comuns, os patógenos entrariam em contato com elas mais frequentemente, o que aumentaria a probabilidade de mecanismos de escape serem selecionados positivamente, reduzindo a vantagem seletiva dos portadores (Apanius, $\mathrm{P}$ et al 1997) 
Prugnolle \& Balloux, (2005) encontraram uma correlação positiva entre a diversidade de patógenos e a diversidade de $H L A$ em populações de determinadas regiões, obtendo associações significativas para a correlação entre diversidade viral e de $H L A-B$. Eles concluíram que a pressão de seleção exercida por patógenos pode ter um papel importante na manutenção da diversidade de $H L A$.

Porém, a correlação entre diversidade de patógenos e de HLA é também compatível com outros modelos seletivos. Entre eles há modelos que assumem haver uma constante mudança no conjunto de patógenos com os quais a população entra em contato, processo que pode resultar em mudanças constantes na pressão de seleção sobre os genes gerando um aumento da diversidade desses genes Hedrick 2002.

As evidências a favor de seleção, baseadas em testes de genética de populações, são extensas. Hedrick \& Thomson, (1983)mostraram que diversas populações apresentam uma maior variabilidade para os genes $H L A-A,-B$ e $-C$ do que o esperado sobre neutralidade, resultado posteriormente confirmado em diversos estudos (Meyer et al, 2006, Solberg et al., 2008). Outra forte evidência de seleção vem do fato das taxas de substituição não sinônimas (as que alteram o aminoácido especificado pelo códon) nos códons da fenda apresentadora de peptídeo serem mais elevadas do que as taxas sinônimas, algo extremamente raro nos demais genes, e consistente com forte pressão para múltiplas mudanças adaptativas (Hughes, A L \& Nei, 1988)

Finalmente, alelos HLA apresentam alta divergência entre eles, muito Hedrick and Thomson (1983) maior do que para outras regiões do genoma, um padrão consistente com forte seleção balanceadora (BUBB et al. 2006). 


\section{4- Justificativa}

Em conjunto, os resultados de análises populacionais para genes HLA indicam que a seleção natural moldou importantes aspectos da sua variação genética. Nesse contexto, o nosso estudo não tem como objetivo documentar a existência de seleção natural em genes HLA, mas sim de compreender em maior detalhe aspectos específicos do processo de seleção nesses genes. Especificamente, investigaremos quais aspectos da variação genética de populações indígenas da América do Sul, para genes HLA, é atribuível a fenômenos demográficos e quais são atribuíveis a processos seletivos. Ainda há poucos estudos que exploram, com dados para HLA e marcadores supostamente neutros para um mesmo conjunto de dados, a interação entre os processos demográficos e seletivos sobre esses genes, e é plausível que a forte deriva à qual essas populações estiveram sujeitas resultou em mudanças de frequência alélica que tornam os efeitos da seleção recente impossíveis de se detectados. Além disso, não é fácil detectar seleção natural atuando em escalas de tempo muito recentes, na ordem de centenas de anos, pois a maior parte dos testes de neutralidade apresenta baixo poder para variação nessa escala de tempo. Entretanto, o uso de populações miscigenadas tem se revelado uma importante ferramenta e nos permitirá testar a hipótese de que a seleção natural em genes HLA também atua em escalas de tempo recente, e moldou aspectos da variação genética de populações miscigenadas da América do Sul. 


\section{Capítulo 1. Evolução dos genes HLA de classe II no contexto das populações nativas da América do Sul.}

\section{1- Introdução}

A variabilidade genética em genes HLA vem sendo estudada há muitas décadas, e tem permitido obter informações a respeito de dois processos evolutivos. Primeiro, os genes altamente polimórficos do MHC tem se revelado informativos sobre a história demográfica e os processos de migrações humanos (Sanchez-Mazas, Lemaître, \& Currat, 2012). Em segundo lugar, esses genes representam valisoso "estudos de caso" sobre como a seleção natural molda a variabilidade genética entre e dentro de populações humanas (Solberg et al., 2008).

Sob essa perspectiva, o fato dos genes HLA serem bem caracterizados do ponto de vista funcional (ver Introdução), com profundo conhecimento sobre as bases moleculares de como as moléculas HLA participam da resposta imune adaptativa (Klein et al., 2000), e de também serem muito bem documentados como alvos de seleção natural (Meyer et al., 2006), oferece um valioso contexto para estudos evolutivos.

Portanto, podemos (Holcomb et al., 2011)partir da premissa de que há seleção, para então abordar questões sobre como o regime seletivo varia entre populações, como os efeitos da seleção diferem entre os genes HLA, e como a história demográfica e a seletiva interagem uma coma outra.

Neste capítulo apresentamos um estudo da variabilidade genética dos genes $H L A$ de classe II $D R B 1, D Q B 1$ e $D P B 1$ em populações ameríndias. Nosso estudo se propõe a 
investigar como processos demográficos e seletivos moldaram a variação genética observada.

Para isso, é necessaria a descrição, mesmo que breve, das características principais da ocupação do continente americano como forma de contextualizar nossa pergunta diante da historia demográfica das populações nativas das Américas.

\section{1- Modelo de povoamento do Continente Americano}

O povoamento do continente americano, que ocorreu há aproximadamente 20.000 anos, e os sucessivos gargalos demográficos associados à rápida expansão populacional ao longo do continente em direção ao sul (Kitchen, Miyamoto, \& Mulligan, 2008) explicam o resultado clássico de perda de diversidade observada nas populações ameríndias em relação às populações do resto do mundo (Bowcock et al., 1994;Pérez-Lezaun et al., 1997; Wang et al., 2007; Nunes, 2011).

Os estudos que corroboram essa afirmação analisaram a diversidade genética em populações ameríndias e a maioria dos marcadores moleculares investigados indicou um padrão de diversidade diferente do observado nas populações dos demais continentes. Análises mostram um decréscimo de variação genética intra-populacional, associado a um aumento da diferenciação inter-populacional partindo da África Sub-Saariana, passando por Eurásia, Leste da Ásia e Oceania até a América (Rosenberg et al., 2005, Zhivotovsky et al, 2003, Prugnolle et al., 2005) Além disso, para a maior parte dos marcadores, os alelos observados em populações nativas americanas são subconjuntos dos encontrados no leste asiático, de acordo com a hipótese de que essas populações foram fundadas a partir de indivíduos vindos da Ásia (revisado em Salzano, 2002). 
Além disso, independente das discussões a respeito dos processos migratórios América adentro, é amplamente aceito que a ocupação de toda a extensão do continente americano se deu por pequenas migrações sequenciais. A hipótese é a de que um subgrupo da população parental deslocou-se para regiões ainda não habitadas mais ao sul do continente, fundaram novas pequenas populações que se expandiram, das quais partiram outros subgrupos que fundaram outras populações e assim sucessivamente. Como consequência, pequenos gargalos populacionais sequenciais contribuíram para a diminuição da diversidade genética. Esse cenário é corroborado pela observação da existência de um gradiente de perda de diversidade genética na América do Sul em relação à América do Norte (Dixon et al., 2007; WANG et al., 2007; NUNES, 2011). Esses dados também ilustram que o sentido do povoamento foi do Norte para o Sul do continente americano.

\section{2- Caracterização da diferenciação populacional na América do Sul}

As populações da América do Sul são as que apresentam os menores índices de diversidade genética e maior diferenciação populacional entre as populações humanas, sendo que esse padrão é mais pronunciado nas populações do leste da América do Sul (Wang et al., 2007).

A América do Sul apresenta como característica marcante uma clara diferenciação entre as populações nativas que vivem na porção oeste das populações nativas que vivem na porção leste do continente. Essa característica é relatada em diversos estudos, baseados em marcadores genéticos clássicos (Cavalli-Sforza et al., 1994), DNA mitocondrial (Fuselli et al., 2003) cromossomo Y (Tarazona-Santos et al., 2001), microssatélites autossômicos (Wang et al., 2007; Nunes, 2011). Esses estudos 
sugerem que há diferenças marcantes entre os perfis genotípicos dos grupos populacionais dessas duas regiões da América do Sul.

Além disso, alguns estudos apontam que populações do sudoeste e o leste da Amazônia apresentam características distintas. Salzano e Callegari-Jacques (1988), através de análises antropométricas, mostram que indivíduos nativos do Noroeste da América do Sul ao Sudoeste da Amazônia apresentam menor estatura que indivíduos do Leste da Amazônia e Centro-Sul da América do Sul. Estudos com DNA mitocondrial também evidenciam diferenças na distribuição das frequências dos haplogrupos de DNAmt entre sudoeste e leste da Amazônia (Mesa et al., 200; Mulligan et al., 2004). E dados de microssatélites autossômicos apontam para o sudoeste e leste da Amazônia como grupos populacionais distintos (Nunes 2011).

\section{3- HLA e populações ameríndias}

As primeiras análises feitas para genes HLA em populações ameríndias mostraram, a partir de dados sorológicos, que a diversidade nas populações nativoamericanas é um subconjunto do que se observava no continente asiático (Kostyu \& Amos, 1981). No início da década de 90, outros estudos apontaram a presença de alelos exclusivos do gene $H L A-B$ em populações nativas da América do Sul (Belich et al., 1992, Watkins et al., 1992) Observou-se que esses alelos eram fruto de conversão gênica (eventos de micro-recombinação) entre alelos já observados em baixa frequência no resto do mundo. Um resultado um pouco diferente, mas que aponta para o mesmo sentido, foi o observado por Francisco (2009). Em um estudo realizado com 26 populações nativo americanas, o autor verificou a presença de alelos endêmicos, ou seja, que só ocorriam na América e que se originaram por conversão gênica entre alelos 
observados no resto do mundo. A diferença em relação aos outros estudos é que o tipo de alelo endêmico observado variava para cada região do continente (ex: América do Sul, Andes, etc) e não por população.

Uma teoria que explica a substituição dos alelos "antigos" por alelos "novos", resultantes das conversões gênicas, é a do turnover alélico. De acordo com esse modelo, os alelos exclusivos das populações nativas das Américas teriam aumentado de frequência, pois eram mais eficientes na apresentação de antígenos patogênicos (exclusivos desse novo ambiente) ao sistema imune. Soma-se a esse cenário o fluxo gênico e deriva genética, que podem ter contribuído para a efetivação desse processo. (Belich et al., 1992, Watkins et al., 1992, Cadavid \& Watkins, 1997; Parham et al., 1997).

Nesse contexto, Francisco (2009) também aponta sinais significativos de seleção balanceadora obtidos pelo teste de D de Tajima, mas que em sua interpretação, indicam um sinal seletivo anterior à entrada das primeiras populações nas Américas, que remetem ao período de divergência entre as diferentes linhagens de $H L A-B$.

Estudos adicionais envolvendo genes HLA de classe II, também baseados na distribuição de frequências alélicas dentro de populações (Solberg, et al, 2008) indicam que DRB1 e DQB1 estão sob seleção balanceadora em múltiplas populações humanas, mas que o lócus DPB1 apresenta frequências alélicas consistentes com neutralidade ou seleção direcional. Entretanto, esses estudos também demonstraram que a América do Sul é uma das regiões do mundo com uma menor proporção de desvios indicativos de seleção balanceadora. 


\section{2- Justificativa}

A investigação da diversidade de genes do MHC em populações isoladas pode revelar polimorfismos balanceados, ou seja, que se mantiveram por condições ambientais vividas por essas populações (Prugnolle et al, 2005). O contato com uma diversidade específica de patógenos ao longo de sua história pode revelar polimorfismos que foram perdidos em outras populações do mundo, possibilitando entender a dinâmica da história evolutiva dos genes HLA e das populações nativas das Américas.

O presente estudo valeu-se de dados já obtidos por Nunes (2011) para genótipos de STR (sigla em inglês para Short Tamdem Repeats) espalhados pelo genoma nas mesmas populaçõe Amerindias que serão estuadas, permitindo que se façam inferências sobre a história demográfica dessa região. Dessa forma, foi possível comparar a variação genética entre microssatélites e HLA, e fazer inferências sobre processos demográficos e seletivos.

As inferências sobre história demográfica e seleção foram feitas usando testes de neutralidade, análises de diferenciação genética baseada em $\mathrm{F}_{\mathrm{ST}}$, e análises da distribuição geográfica de alelos HLA. Até o momento há relativamente poucos estudos que envolveram um grande número de populações ameríndias genotipadas para HLA de classe II usando metodologias de alta resolução, e a aplicação de tais métodos é essencial para realizar uma análise da distribuição mundial de alelos. 


\section{3- Objetivos}

\section{1- Geral}

O objetivo geral deste estudo foi investigar o modo como processos demográficos e seletivos conjuntamente moldam a variação genética para os loci HLADRB1, HLA-DQB1 e HLA-DPB1 em populações nativas da América do Sul, a partir da análise comparativa desses genes com um painel de microssatélites, previamente genotipados nas mesmas amostras.

\section{2 - Específicos}

- Sequenciar o exon dois dos genes HLA-DRB1, HLA-DQB1 e HLA-DPB1 em 15 populações da América do Sul localizadas na Amazônia e Centro Sul do Brasil;

- Comparar os níveis de diversidade genética de Ameríndios da América do Sul com o restante do mundo utilizando dados publicamente disponíveis;

- Identificar alelos geograficamente restritos ou mais frequentes em populações ameríndias;

- Contrastar a diferenciação populacional para marcadores genômicos não-HLA e marcadores HLA, para fazer inferências sobre o papel relativo de processos demográficos e seletivos. 


\section{4- Material e Métodos}

\section{1- Amostragem}

\subsection{1 - Indivíduos genotipados para genes $H L A$ de classe II clássicos.}

Foram utilizados 307 indivíduos de 14 populações nativo-americanas brasileiras, sendo 11 da região amazônica e três do centro sul do Brasil. A Tabela 1 e a Figura 1 mostram as tribos utilizadas nesse estudo com informações sobre o grupo linguístico a que pertencem e localização geográfica.

Tabela 1. Localização, grupo linguístico e tamanho amostras das populações estudadas.

\begin{tabular}{lcccc}
\hline População & Localização & $\begin{array}{c}\text { Grupo } \\
\text { Linguístico }\end{array}$ & $\begin{array}{c}\text { Tamanho } \\
\text { amostral (n) }\end{array}$ & Procedência \\
\hline Tiryió & Amapá & Karib & 17 & LGHM-UFPA \\
Zo'é & Pará & Tupi-Guarani & 8 & LGHM-UFPA \\
Arara do Laranjal & Pará & Karib & 42 & LGHM-UFPA \\
Arara do Iriri & Pará & Karib & 17 & LGHM-UFPA \\
Urubu-Kaapor & Maranhão & Tupi-Guarani & 32 & LGHM-UFPA \\
Parakanã & Pará & Tupi-Guarani & 20 & LGHM-UFPA \\
Asurini & Pará & Tupi-Guarani & 22 & LGHM-UFPA \\
Araweté & Pará & Tupi-Guarani & 30 & LGHM-UFPA \\
Kayapó & Pará & Jê & 16 & LGHM-UFPA \\
Krokraimoro & Pará & Jê & 18 & LGHM-UFPA \\
Kayapó Xikrin & Pará & Jê & 17 & LGHM-UFPA \\
Bakajá Xikrin & Mato Grosso do & Tupi-Guarani & 19 & LGMH- UFPR \\
Guarani Kaiowá & Sul & Tupi-Guarani & 14 & LGMH- UFPR \\
Guarani M'bya & Paraná & Jê & 18 & LGMH- UFPR \\
Kaingang & Paraná & & $\mathbf{3 0 7}$ & \\
\hline Total & & &
\end{tabular}

As amostras de DNA utilizadas foram cedidas por bancos de DNA. As amostras de nativo-americanos da Amazônia estão sob a curadoria do Professor Dr. Eduardo José Melo dos Santos, do Laboratório de Genética Humana e Médica da Universidade Federal do Pará (LGHM UFPA); as amostras de indivíduos das populações Guarani e 
Kaingang estão sob a curadoria da Professora Dra. Maria Luiza Petzl-Erler, do Laboratório de Genética Molecular Humana da Universidade Federal do Paraná (LGMH UFPR).

As amostras utilizadas pelo presente estudo atendem aos requisitos das Resoluções CNS 196/96 e 304/00 sobre Diretrizes e Normas Regulamentadoras de Pesquisa envolvendo Seres Humanos, tendo aprovação do Comitê Nacional de Ética em Pesquisa (CONEP 2046, parecer 332/2001).

\subsection{2- Tratamento das amostras}

Para aumentar a quantidade de DNA, utilizamos a técnica de amplificação de genoma inteiro que se baseia na metodologia de multiple displacement amplification (MDA), implementada pelo kit GenomiPhi, comercializado pela GE Healthcare.

\subsection{3- Bancos de dados}

Além das amostras genotipadas, utilizamos dados publicamente disponíveis no “dbMHC Anthropology” (http://www.ncbi.nlm.nih.gov/ projects/gv/ mhc/ihwg.cgi?cmd $=$ page $\&$ page $=$ AnthroMai), que contém os dados de Workshops Internacionais de Histocompatibilidade. Os detalhes sobre as populações utilizadas para cada gene podem ser encontradas na Tabela 2.

Para o gene $H L A-D R B 1$ foi utilizado um segundo banco de dados de populações nativo-americanas e uma população siberiana que foram previamente analisadas por Wang et. al. (2007) e Nunes (2012). Este banco de dados foi gerado como parte de estudo que está sendo desenvolvido pelo nosso grupo. 
A localização geográfica de todas as populações utilizadas neste estudo está apresentada na Figura 2 (MAPA) e na Tabela 2. 


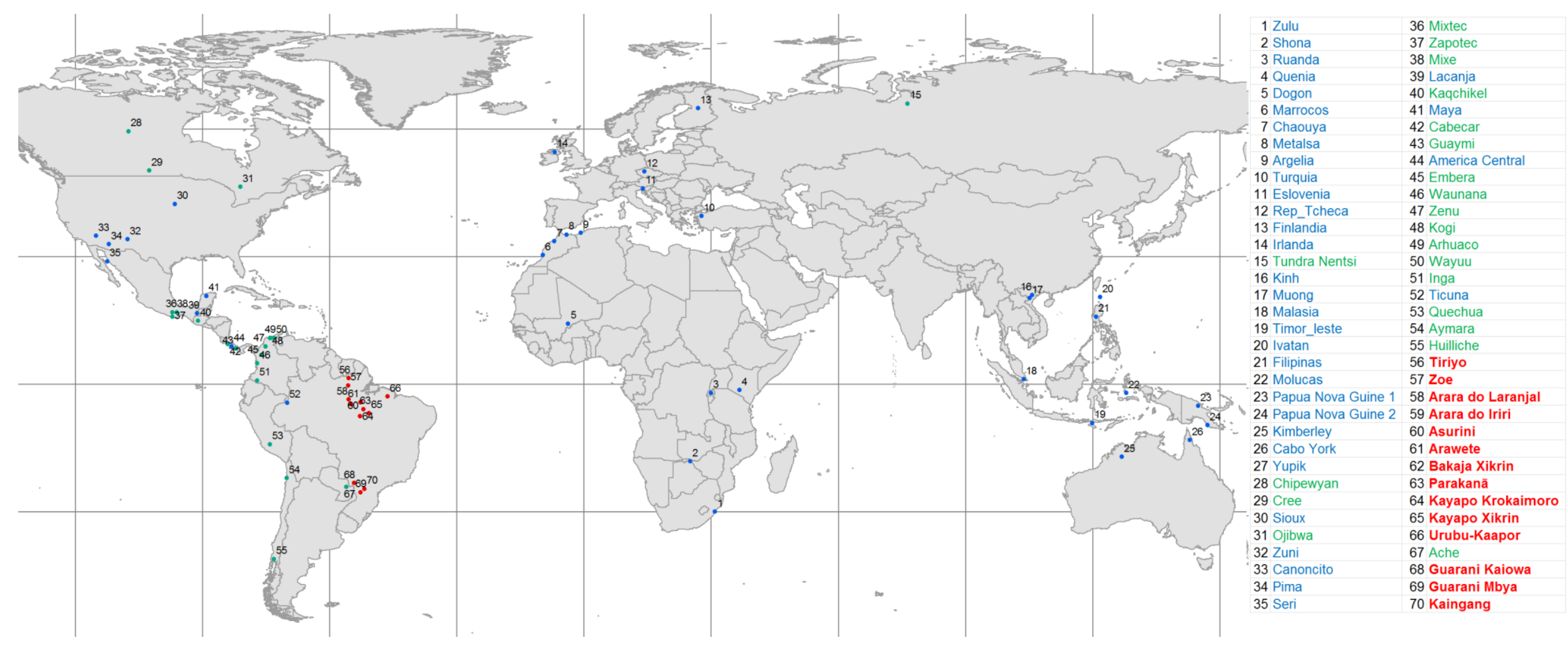

Figura 1: Mapa com a localização das populações utilizadas neste estudo.

*Em vermelho, estão as populações genotipadas para os genes HLA de classe II no presente estudo; em azul, estão as populações do banco de dados do dbMHC Anthropology; e em verde estão as populações previamente genotipadas apenas para $H L A-D R B 1$ (dados não publicados). 
Tabela 2. Descrição, localização, fonte de obtenção e tamanho das amostras utilizadas no presente estudo.

\begin{tabular}{|c|c|c|c|c|c|}
\hline \multirow[b]{2}{*}{ População } & \multirow[b]{2}{*}{ Localização } & \multirow{2}{*}{$\begin{array}{c}\text { Banco de } \\
\text { dados }\end{array}$} & \multicolumn{3}{|c|}{ Tamanho Amostral (n) } \\
\hline & & & $\begin{array}{l}H L A- \\
D R B 1\end{array}$ & $\begin{array}{l}H L A- \\
D Q B 1\end{array}$ & $\begin{array}{l}H L A- \\
D P B 1\end{array}$ \\
\hline Argélia & África & 1 & 99 & 99 & 0 \\
\hline Chaouya & África & 1 & 99 & 0 & 0 \\
\hline Dogon & África & 1 & 138 & 0 & 0 \\
\hline Marrocos & África & 1 & 189 & 194 & 0 \\
\hline Metalsa & África & 1 & 99 & 0 & 0 \\
\hline Quênia & África & 1 & 0 & 113 & 123 \\
\hline Ruanda & África & 1 & 280 & 280 & 0 \\
\hline Shona & África & 1 & 229 & 229 & 228 \\
\hline Zulu & África & 1 & 88 & 87 & 88 \\
\hline Eslovênia & Europa & 1 & 100 & 100 & 100 \\
\hline Finlândia & Europa & 1 & 90 & 29 & 102 \\
\hline Irlanda & Europa & 1 & 1000 & 0 & 0 \\
\hline República Tcheca & Europa & 1 & 103 & 106 & 30 \\
\hline Turquia & Oriente Médio & 1 & 245 & 245 & 0 \\
\hline Kinh & Ásia & 1 & 102 & 100 & 0 \\
\hline Malasia & Ásia & 1 & 54 & 55 & 52 \\
\hline Muong & Ásia & 1 & 83 & 82 & 0 \\
\hline Filipinas & Pacífico & 1 & 94 & 94 & 94 \\
\hline Ivatan & Pacífico & 1 & 50 & 0 & 0 \\
\hline Molucas & Pacífico & 1 & 40 & 46 & 46 \\
\hline Papua Nova Guine 1 & Pacífico & 1 & 87 & 91 & 88 \\
\hline Papua Nova Guine 2 & Pacífico & 1 & 80 & 91 & 48 \\
\hline Timor leste & Pacífico & 1 & 83 & 86 & 86 \\
\hline Kimberley & Austrália & 1 & 41 & 41 & 38 \\
\hline Cabo York & Austrália & 1 & 99 & 99 & 96 \\
\hline Yupik & América do Norte & 1 & 252 & 251 & 0 \\
\hline Canoncito & América do Norte & 1 & 40 & 40 & 40 \\
\hline Lacanja & América do Norte & 1 & 162 & 162 & 0 \\
\hline Maya & América do Norte & 1 & 15 & 15 & 15 \\
\hline Pima & América do Norte & 1 & 17 & 17 & 0 \\
\hline Seri & América do Norte & 1 & 33 & 33 & 0 \\
\hline Sioux & América do Norte & 1 & 96 & 95 & 82 \\
\hline Zuni & América do Norte & 1 & 50 & 50 & 50 \\
\hline América Central & América Central & 1 & 50 & 50 & 50 \\
\hline Ticuna & América do Sul & 1 & 49 & 49 & 49 \\
\hline Total & & & 4336 & 3029 & 1505 \\
\hline Tundra Nentsi & Sibéria & & 16 & - & - \\
\hline Ojibwa & América do Norte & 2 & 16 & - & - \\
\hline Chipewyan & América do Norte & 2 & 25 & - & - \\
\hline Cree & América do Norte & 2 & 18 & - & - \\
\hline Mixtec & América do Norte & 2 & 20 & - & - \\
\hline Zapotec & América Central & 2 & 18 & - & - \\
\hline Mixe & América Central & 2 & 20 & - & - \\
\hline
\end{tabular}




\begin{tabular}{|c|c|c|c|c|c|}
\hline Kaqchikel & América Central & 2 & 19 & - & - \\
\hline Cabecar & América Central & 2 & 20 & - & - \\
\hline Guaymi & América Central & 2 & 13 & - & - \\
\hline Wayuu & $\begin{array}{l}\text { América do } \\
\text { Sul_Oeste }\end{array}$ & 2 & 15 & - & - \\
\hline Arhuaco & $\begin{array}{l}\text { América do } \\
\text { Sul_Oeste }\end{array}$ & 2 & 17 & - & - \\
\hline Kogi & $\begin{array}{l}\text { América do } \\
\text { Sul_Oeste }\end{array}$ & 2 & 14 & - & - \\
\hline Zenu & $\begin{array}{l}\text { América do } \\
\text { Sul_Oeste }\end{array}$ & 2 & 12 & - & - \\
\hline Embera & $\begin{array}{l}\text { América do } \\
\text { Sul_Oeste }\end{array}$ & 2 & 14 & - & - \\
\hline Aymara & $\begin{array}{l}\text { América do } \\
\text { Sul_Oeste }\end{array}$ & 2 & 20 & - & - \\
\hline Waunana & $\begin{array}{l}\text { América do } \\
\text { Sul_Oeste }\end{array}$ & 2 & 20 & - & - \\
\hline Inga & $\begin{array}{l}\text { América do } \\
\text { Sul_Oeste }\end{array}$ & 2 & 15 & - & - \\
\hline Huilliche & $\begin{array}{l}\text { América do } \\
\text { Sul_Oeste }\end{array}$ & 2 & 20 & - & - \\
\hline Quechua & $\begin{array}{l}\text { América do } \\
\text { Sul_Oeste }\end{array}$ & 2 & 21 & - & - \\
\hline Ticuna (Arara) & $\begin{array}{l}\text { América do } \\
\text { Sul_Leste }\end{array}$ & 2 & 14 & - & - \\
\hline Ticuna (Tarapaca) & $\begin{array}{l}\text { América do } \\
\text { Sul_Leste }\end{array}$ & 2 & 19 & - & - \\
\hline Ache & $\begin{array}{l}\text { América do } \\
\text { Sul_Leste }\end{array}$ & 2 & 12 & - & - \\
\hline Total & & & 398 & - & - \\
\hline Tiryió & $\begin{array}{l}\text { América do } \\
\text { Sul_Leste }\end{array}$ & 3 & 13 & 13 & 13 \\
\hline Zo'é & $\begin{array}{l}\text { América do } \\
\text { Sul_Leste }\end{array}$ & 3 & 8 & 0 & 0 \\
\hline Arara do Laranjal & $\begin{array}{l}\text { América do } \\
\text { Sul_Leste }\end{array}$ & 3 & 41 & 50 & 36 \\
\hline Arara do Iriri & $\begin{array}{l}\text { América do } \\
\text { Sul_Leste }\end{array}$ & 3 & 15 & 17 & 12 \\
\hline Urubu-Kaapor & $\begin{array}{l}\text { América do } \\
\text { Sul_Leste }\end{array}$ & 3 & 22 & 16 & 8 \\
\hline Parakanã & $\begin{array}{l}\text { América do } \\
\text { Sul_Leste }\end{array}$ & 3 & 11 & 15 & $5^{*}$ \\
\hline Asurini & $\begin{array}{l}\text { América do } \\
\text { Sul_Leste }\end{array}$ & 3 & 22 & 20 & 11 \\
\hline Araweté & $\begin{array}{l}\text { América do } \\
\text { Sul_Leste }\end{array}$ & 3 & 27 & 26 & $4^{*}$ \\
\hline $\begin{array}{l}\text { Kayapó } \\
\text { Krokraimoro }\end{array}$ & $\begin{array}{l}\text { América do } \\
\text { Sul_Leste }\end{array}$ & 3 & 16 & 14 & 9 \\
\hline Kayapó Xikrin & América do & 3 & 16 & 9 & $5^{*}$ \\
\hline
\end{tabular}




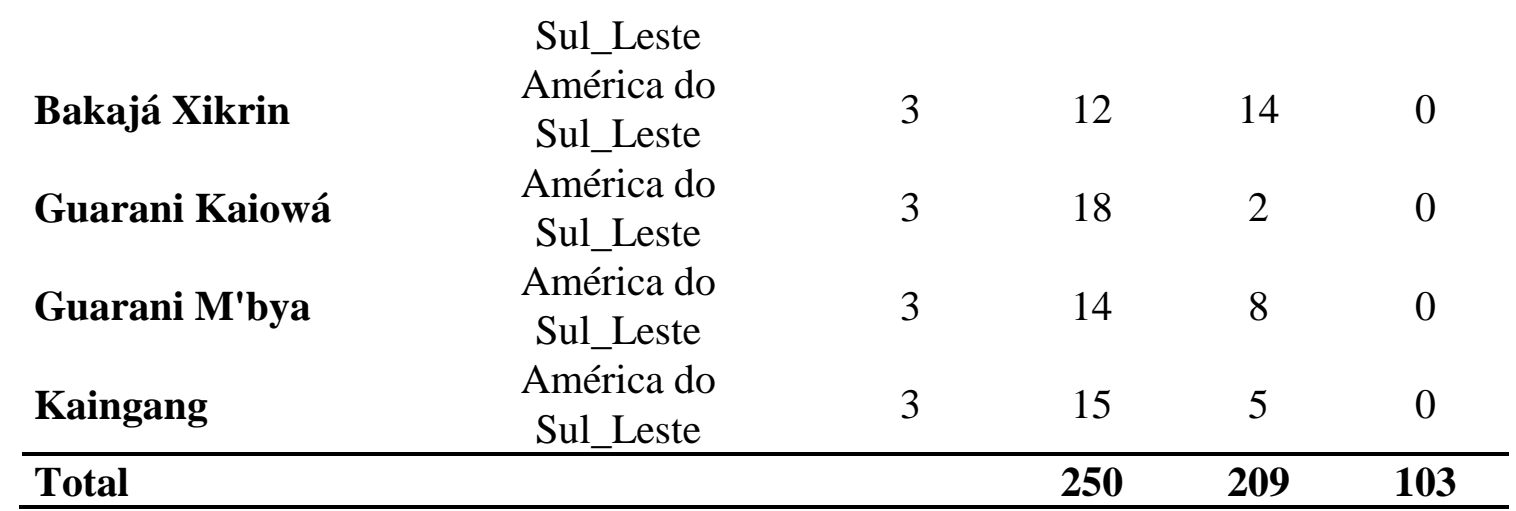

Banco de dados 1- dbMHC; 2- Dados ainda não publicados do grupo; 3-Presente estudo *Amostra foi removida devido ao baixo número de indivíduos genotipados.

\section{2- Amplificação, sequenciamento e genotipagem do exon 2 dos genes}

\section{HLA de classe II.}

A genotipagem dos alelos de genes $H L A$ de classe II clássicos foi feita por PCR e sequenciamento do exon dois dos genes $H L A-D R B 1,-D Q B 1$ e $-D P B 1$, seguindo os protocolos descritos por (Sayer et al., 2001) para HLA-DRB1 e International Histocompatibility Working Group (IHWG) para HLA-DQB1 e -DPB1.

Os oligonucleotídeos utilizados nas reações de PCR estao descritos na Tabela 3. 
Tabela 3- Sequência de oligonucleotideos iniciadores utilizados na amplificação e sequenciamento do exon dos loci $H L A-D R B 1$, -DQB1 $e$ -DPB1.

\begin{tabular}{|c|c|c|c|}
\hline ID & $5 \mathbf{5}^{\prime} / \mathbf{3}^{\prime}$ & Grupo alélico & Sequencia dos Oligonucleotideos \\
\hline \multicolumn{4}{|l|}{ PCR } \\
\hline \multicolumn{4}{|l|}{ HLA-DRB1 } \\
\hline DRB1-52.1(12) & $5^{\prime}$ & DRB1 $1 * 3,11,12,13,14,08$ & 5'- CAGGAAACAGCTATGACCCCCACAGCACGTTTCTTGGAGTACYCTA-3' \\
\hline DRB1-01(13) & $5^{\prime}$ & $\mathrm{DRB} 1 * 01$ & 5'-CAGGAAACAGCTATGACCTGAGACGCACGTTTCTTGTGGSAGCTTAAGTT-3' \\
\hline DRB1-07(14) & $5^{\prime}$ & $\mathrm{DRB} 1 * 07$ & 5'-CAGGAAACAGCTATGACCTGAGACTCACGTTTCCTGTGGCAGGGTAARTATA-3' \\
\hline DRB1-09(13) & $5^{\prime}$ & DRB $1 * 09$ & 5'-CAGGAAACAGCTATGACCTGACCAGCACGTTTCTTGAAGCAGGATAAGTT-3' \\
\hline DRB1-10(11) & $5^{\prime}$ & $\mathrm{DRB} 1 * 10$ & 5'-CAGGAAACAGCTATGACCTGAA $\overline{\text { GACCACGTTTCTTGGAGGAGG-3' }}$ \\
\hline DRB1-15(13) & $5^{\prime}$ & $\mathrm{DRB} 1 * 15,16$ & 5'-CAGGAAACAGCTATGACCTGAGACTCACGTTTCCTGTGGCAGCCTAAGA-3' \\
\hline DRB1-04(13) & $5^{\prime}$ & $\mathrm{DRB} 1 * 04$ & 5'-CAGGAAACAGCTATGACCTGAGACGCACGTTTCTTGGAGCAGGTTAAAC$-3 '$ \\
\hline DRB1 (91).M13R & $3^{\prime}$ & Todos os grupos de DRB1 & 5'-TGTAAAACGACGGCCAGTGCTYACCTCGCCKCTGCAC-3' \\
\hline \multicolumn{4}{|r|}{ 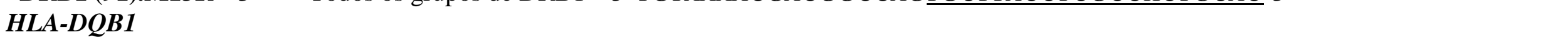 } \\
\hline DQB1-F & $5^{\prime}$ & Todos os grupos de DQB1 & 5'-TGTAAAACGACGGCCAGTTCCTCGCAGAGGATTTCG-3' \\
\hline DQB1-020304 R & $3^{\prime}$ & $\mathrm{DQB} 1 * 02,03$ e 04 & 5'-CAGGAAACAGCTATGACCGTGCGGAGCTCCAACTG-3' \\
\hline DQB1- 0506 R & $3^{\prime}$ & DQB $1 * 05$ e 06 & 5'-CAGGAAACAGCTATGACC $\overline{\text { TCTCCTCTGCAAGATCCC-3' }}$ \\
\hline \multicolumn{4}{|l|}{$H L A-D P B 1$} \\
\hline DPB1 - F & $5^{\prime}$ & Todos os grupos de DPB1 & 5'-AGGACCACAGAACTCGGTACTAGGA-3' \\
\hline DPB1 - R & $3^{\prime}$ & Todos os grupos de DPB2 & 5'-TGAATCCCCAACCCAAAGTCCCC-3' \\
\hline \multicolumn{4}{|l|}{ Sequenciamento } \\
\hline \multicolumn{4}{|l|}{$H L A-D R B 1$} \\
\hline DRB1M13F & $5^{\prime}$ & Todos os grupos de DRB1 & 5'-CAGGAAACAGCTATGACC-3' \\
\hline DRB1M13R & $3^{\prime}$ & Todos os grupos de DRB1 & 5'-TGTAAAACGACGGCCAG-3' \\
\hline \multicolumn{4}{|l|}{$H L A-D Q B 1$} \\
\hline DQB1SEQF & $5^{\prime}$ & Todos os grupos de DQB1 & 5'-TGTAAAACGACGGCCAGT-3' \\
\hline DQB1SEQR & $3^{\prime}$ & Todos os grupos de DQB1 & 5'-CAGGAAACAGCTATGACC-3' \\
\hline \multicolumn{4}{|l|}{$H L A-D P B 1$} \\
\hline DPB1SEQF & $5^{\prime}$ & Todos os grupos de DPB1 & 5'-GAGAGTGGCGCCTCCGCTC-3' \\
\hline DPB1SEQR & $3^{\prime}$ & Todos os grupos de DPB2 & 5'-CCGGCCCAAAGCCCTCACTC-3' \\
\hline
\end{tabular}


Para a reação de PCR do exon 2 de $H L A-D R B 1$ há uma particularidade: os oligonucleotídeos específicos para a detecção de linhagem de alelos, cuja ancoragem ocorre a montante do exon, foram misturados de forma a apresentarem uma concentração final igual de $0,5 \mathrm{pmol} / \mu \mathrm{L}$ no volume final da reação de PCR. Essa metodologia é decrita por Sayer et al (2003) como One tube Amplification. Ela é inovadora já que na maioria dos estudos os individuos são primeiramente testados para a definição das linhagens, por metodos de baixa resolução e, em seguida, diferentes reações de PCR são realizadas para a amplificação alelo-específica. $\mathrm{Na}$ técnica desenvolvida por Sayer et al (2003), a etapa de triagem é eliminada e os inúmeros PCRs linhagem específicos por individuo reduzidos a apenas um.

Os reagentes utilizados em todas as reações de PCR bem como suas concentrações estão listados na tabela 4.

Tabela 4: Reagentes para realização das reações de PCR nos genes $H L A$ de classe II

\begin{tabular}{lll}
\hline Reagentes & [] inicial & [] final \\
\hline Tampão* & $10 \mathrm{X}$ & $1 \mathrm{X}$ \\
MgCl2 & $50 \mathrm{mM}$ & $1,87 \mathrm{mM}$ \\
dNTP & $2 \mathrm{mM}$ & $0,2 \mathrm{mM}$ \\
Oligonucleotídeos $(\mathbf{F})$ & $25 \mathrm{pmol} / \mu \mathrm{L}$ & $0,5 \mathrm{pmol} / \mu \mathrm{L}$ \\
Oligonucleotídeos $(\mathbf{R})$ & $25 \mathrm{pmol} / \mu \mathrm{L}$ & $0,5 \mathrm{pmol} / \mu \mathrm{L}$ \\
Enzima Taq polimerase & $5 \mathrm{U} / \mu \mathrm{L}$ & $1 \mathrm{U}$ \\
DNA & $100 \mathrm{ng} / \mu \mathrm{L}$ & $5 \mathrm{ng} / \mu 1$ \\
Vol.Final & & $20 \mu 1$ \\
\hline
\end{tabular}

* A composição do tampão $1 \mathrm{X}$ é: tris pH 9,0 a 0,08M, $\left(\mathrm{NH}_{4}\right)_{2} \mathrm{SO}_{2}$ a 0,02M e tween $0,1 \%$. 
Todos os produdos de amplificação foram submetidos à eletroferese em gel de agarose a 1,5\% corados por Gel Red ® (Invitrogen). A concentração da amplificação foi medida durante a eletroforese com o auxílio do marcador molecular Low DNA Mass Ladder (Invitrogen).

O tamanho dos fragmentos gerados para os loci HLA-DRB1, -DQB1 e DPB1, correspondentes apenas ao exon 2 foi 270,240 e 263 pares de base, respectivamente.

Os produtos de PCR amplificados tinham sua concentração ajustada para 20$30 \mathrm{ng} / \mu \mathrm{l}$ e eram submetidas a purificação com as enzimas Exonuclease I (GE Healthcare) (EXO) e Fosfatase Alcalina de Camarão (GE Healthcare) (SAP). A reação consistia na adição de $2 \mu \mathrm{L}$ de EXO+SAP (à uma proporçãod e 1:1) à $10 \mu \mathrm{L}$ de produto de PCR. As condições de temperatura da reação de purificação encontram-se na Tabela 4.

Os produtos de PCR purificados foram submetidos à reação de sequenciamento com o auxílio do kit de dideoxinucleotídeos BigDye Termiantor V3.0 () (Applied Biosystems). Os oligonucleotídeos iniciadores utilizados nas reações de sequenciamento estao na Tabela 5.

As reações de sequenciamento foram submetidas à eletroforese de fragmentos no sequenciador automático ABI 3130 (Applied Byosistems) do Laboratório de Imunogenética (LIG), coordenado pela Dra. Margareth Torres, e que é vinculado ao Hospital Albert Eisntein, em São Paulo. 
Tabela 5: Condições de temperatura para realização da $\mathrm{PCR}$, purificação e sequnciamento dos genes $H L A$ de classe II

\begin{tabular}{|c|c|c|c|}
\hline Locus & PCR & $\begin{array}{l}\text { Purificação do } \\
\text { PCR }\end{array}$ & $\begin{array}{l}\text { Reação de } \\
\text { Seqüienciamento }\end{array}$ \\
\hline$H L A-D R B 1$ & $\begin{array}{l}95^{\circ} \mathrm{C} \text { por } 10 \mathrm{~min} ; 30 \\
\text { ciclos de } 95^{\circ} \mathrm{C} \text { por } 20 \mathrm{seg} \text {, } \\
60^{\circ} \mathrm{C} \text { por } 15 \mathrm{seg}, 72^{\circ} \mathrm{C} \\
\text { por } 40 \mathrm{seg} ; 72^{\circ} \mathrm{C} \text { por } 20 \\
\text { min }\end{array}$ & $\begin{array}{l}\text { Incubação por uma } \\
\text { hora a } 37^{\circ} \mathrm{C} \text {, } \\
\text { seguida de } \\
\text { desnaturação } 15 \\
\text { min a } 80^{\circ} \mathrm{C} \text {. }\end{array}$ & $\begin{array}{l}96^{\circ} \mathrm{C} \text { por } 20 \text { seg e } 30 \\
\text { ciclos de: } 96^{\circ} \mathrm{C} \text { por } \\
10 \text { seg, } 55^{\circ} \mathrm{C} \text { por } 10 \text { seg } \\
\text { e } 60^{\circ} \mathrm{C} \text { por } 1 \mathrm{~min} .\end{array}$ \\
\hline$H L A-D Q B 1$ & $\begin{array}{l}95^{\circ} \mathrm{C} \text { por } 10 \mathrm{~min} ; 8 \text { ciclos } \\
\text { de: } 95^{\circ} \mathrm{C} \text { por } 10 \mathrm{seg}, 65^{\circ} \mathrm{C} \\
\text { por } 40 \mathrm{seg}, 72^{\circ} \mathrm{C} \text { por } 40 \\
\text { seg; seguidos de } 28 \text { ciclos } \\
\text { de: } 950 \mathrm{C} \text { por } 10 \mathrm{seg}, 55^{\circ} \mathrm{C} \\
\text { por } 30 \mathrm{seg}, 72^{\circ} \mathrm{C} \text { por } 40 \\
\text { seg; } 72^{\circ} \mathrm{C} \text { por } 20 \mathrm{~min}\end{array}$ & $\begin{array}{l}\text { Incubação por uma } \\
\text { hora a } 37^{\circ} \mathrm{C} \text {, } \\
\text { seguida de } \\
\text { desnaturação } 15 \\
\text { min a } 80^{\circ} \mathrm{C} \text {. }\end{array}$ & $\begin{array}{l}40 \text { ciclos de } 96^{\circ} \mathrm{C} \text { por } \\
20 \mathrm{seg}, 60^{\circ} \mathrm{C} \text { por } 2 \mathrm{~min} \\
\text { e } 30\end{array}$ \\
\hline$H L A-D P B 1$ & $\begin{array}{l}95^{\circ} \mathrm{C} \text { por } 10 \mathrm{~min} ; 10 \\
\text { ciclos de: } 95^{\circ} \mathrm{C} \text { por } 10 \mathrm{seg} \text {, } \\
65^{\circ} \mathrm{C} \text { por } 60 \mathrm{seg} \text {; seguidos } \\
\text { de: } 30 \text { ciclos de: } 95^{\circ} \mathrm{C} \\
\text { por } 10 \mathrm{seg}, 70 \mathrm{C} \text { por } 50 \\
\text { seg, } 72 \text { oC por } 30 \mathrm{seg} ; \\
72^{\circ} \mathrm{C} \text { por } 20 \mathrm{~min}\end{array}$ & $\begin{array}{l}\text { Incubação por uma } \\
\text { hora a } 37^{\circ} \mathrm{C} \text {, } \\
\text { seguida de } \\
\text { desnaturação por } \\
15 \text { min a } 80^{\circ} \mathrm{C} \text {. }\end{array}$ & $\begin{array}{l}96^{\circ} \mathrm{C} \text { por } 20 \text { seg e } 30 \\
\text { ciclos de: } 96^{\circ} \mathrm{C} \text { por } \\
10 \text { seg, } 55^{\circ} \mathrm{C} \text { por } 10 \text { seg } \\
\text { e } 60^{\circ} \mathrm{C} \text { por } 1 \mathrm{~min} .\end{array}$ \\
\hline
\end{tabular}

\section{3- Edição de sequências e determinação dos haplótipos e alelos de}

\section{HLA}

Os eletroferogramas gerados pelo sequenciador foram analisados com o auxílio do programa Sequencher ®. A edição das sequências foi feita por indivíduo e os sítios polimórficos foram editados de acordo com os códigos preconizados pela IUPAC (International Union of Pure and Applied Chemistry). (Figura XXX) 


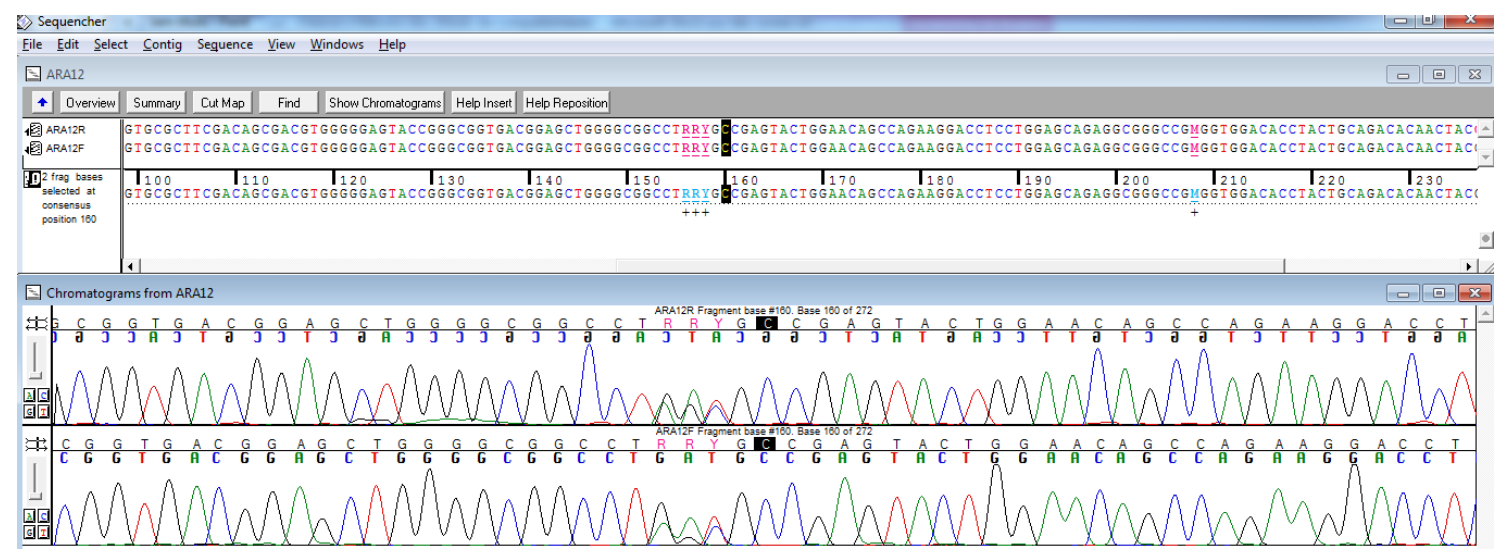

Figura 2: Layout do programa Sequecher ${ }^{\circledR}$ para edição das sequencias de exon 2 dos genes HLA.

A inferência de fase haplotípica para cada individuo foi feita com o auxílio da ferramenta on-line do dbMHC SBT (sequence based typing) (http://www.ncbi.nlm.nih.gov/gv/mhc/sbt.cgi?cmd=main). Essa ferramenta utiliza a informação genotípica para todas as posições do exon 2 (obtidas pelo sequenciamento) para inferir qual pares de alelos HLA tem sequências compatíveis com os dados observados (Helmberg \& Feolo, 2004).

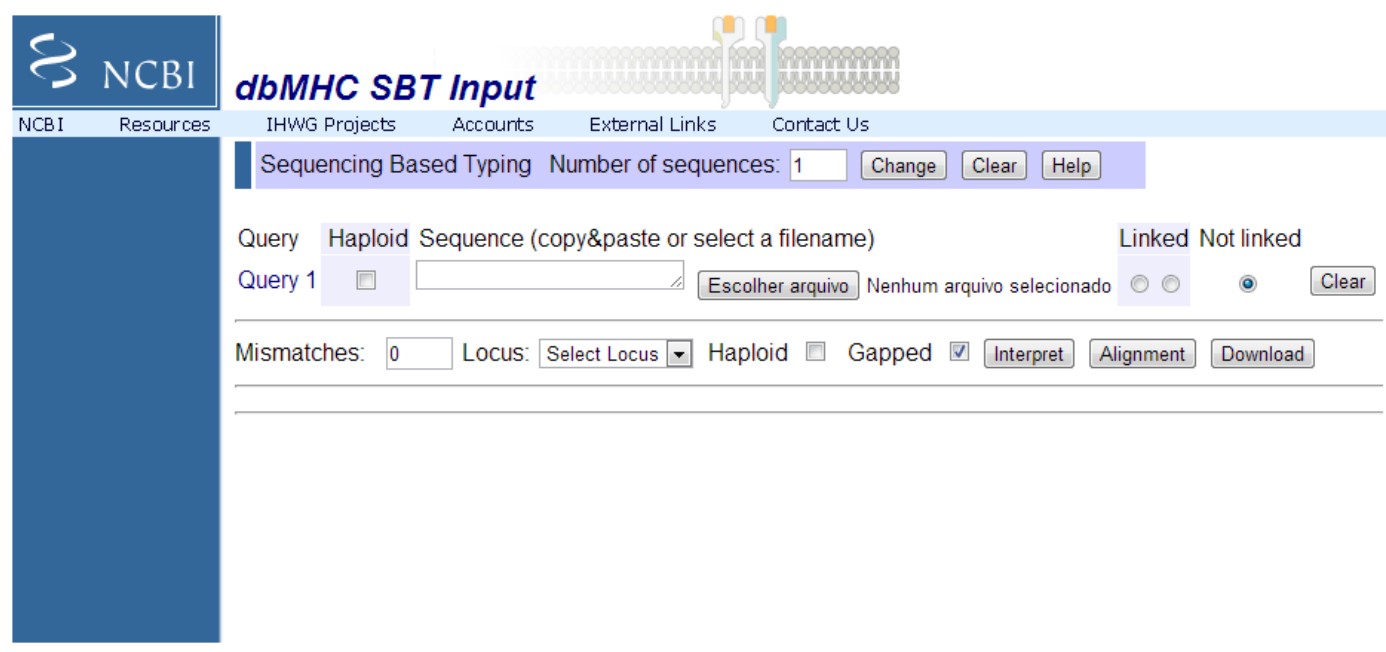

Figura 3- Página Inicial da ferramenta de análise de SBT online do dbMHC. 
As ambiguidadedes de genótipo, que ocorrem quando existe mais de uma possibilidade de pares de alelos para um mesmo genótipo, foram resolvidas com o auxílio de primers específicos para os códons ambíguos e, em alguns casos, o melhor genótipo era escolhido usando como critério a frequência de seus alelos em dados já publicados em banco de dados para aquela mesma população ou região (http://www.allelefrequencies.net/) ou Material suplementar do estudo realizado por Solberg et al 2008 (http://www.pypop.org/popdata/)

\section{4- Nomenclatura dos alelos HLA}

A nomenclatura dos alelos HLA obedece às regras instituídas em um comitê internacional (Marsh, 2013). Os nomes dos são determinados pelo haplótipo completo do gene, que inclui as sequências de regiões codificantes e não-codificantes de proteína. A Figura 4ilustra o significado dos conjuntos de dígitos presentes no nome de cada alelo.

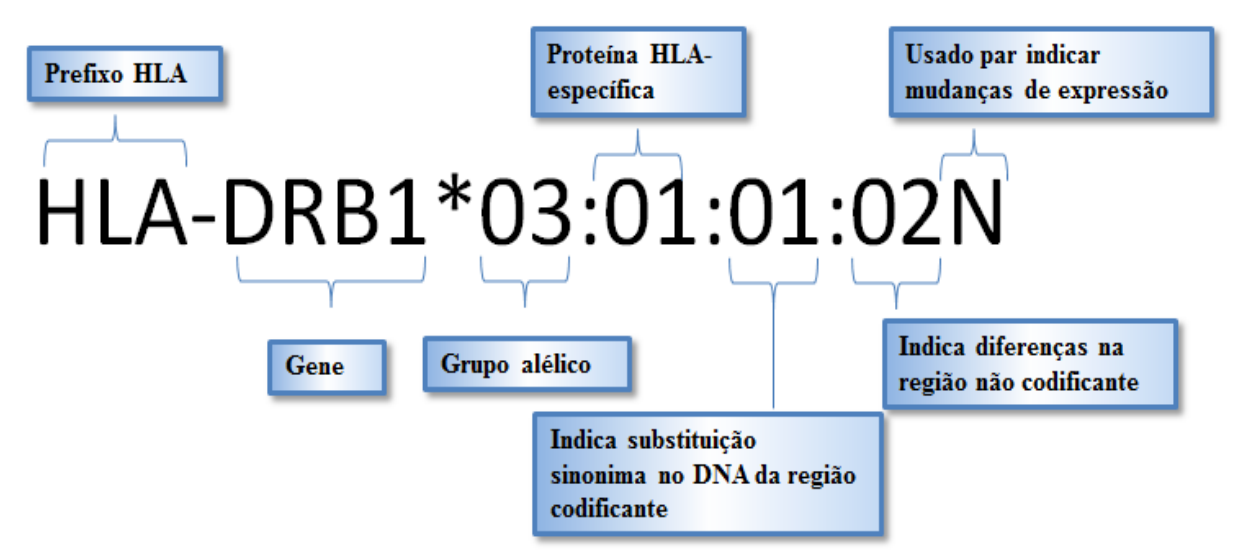

Figura 4- Nomenclatura dos alelos de genes $H L A$.

O primeiro e segundo conjunto de dígitos representam variação nucleotídicas não sinônimas, ou seja, que resultam na mudança de aminoácidos na sequência da proteína. As alterações sinônimas, que ocorrem na sequência de DNA codificante do 
gene, mas que não resultam em mudança de aminoácidos são representadas pelo terceiro conjunto de dígitos. Mudanças nos introns e regiões não codificantes (3' e 5' não traduzidas) são representadas pelo quarto conjunto de dígitos.

\section{5- Montagem do banco de dados}

Para que fosse possível realizar as análises moleculares com dados gerados em diferentes lugares e, portanto, utilizando diferentes técnicas de inferência de haplótipos, (com diferentes resoluções, que variavam de 1 a 3 conjuntos de dígitos ver Figura 4), decidimos editar o banco de dados compilado da seguinte maneira:

1- Removemos todas as genotipagens com apenas 1 conjunto de dígitos. Esse tipo de dado é comumente obtido em técnicas de baixa resolução, como s sorológicas;

2- Nas situações em que a resolução era de 3 ou mais conjuntos, criamos alelos genéricos de 2 dígitos, eliminando as posições sinônimas que diferenciavam alelos do mesmo grupo. (Figura 5)

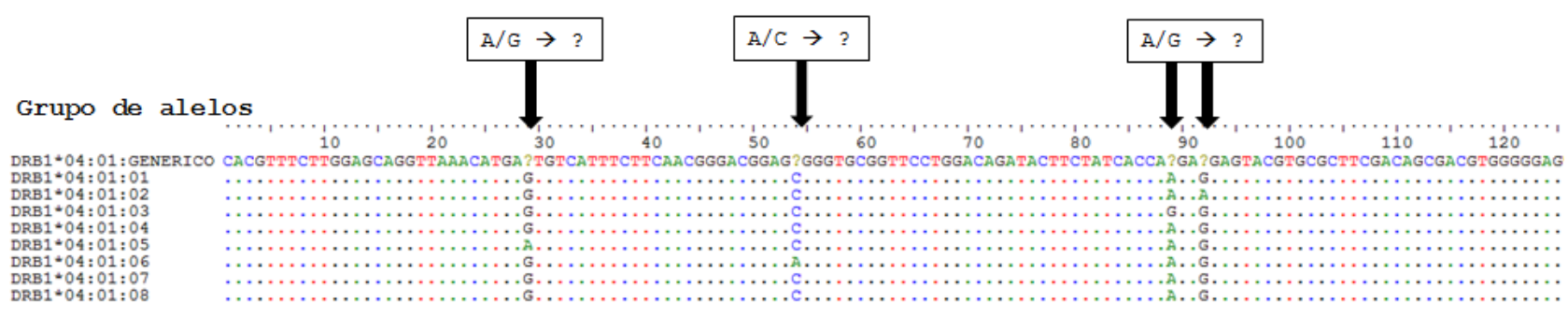

Figura 5: Eliminação de posições sinônimas em grupos de alelos. $O$ alelo genérico passou a ser o representante de toda a variação genética codificante do grupo alélico.

3- Esse processo aumentou a quantidade de indeterminações nas sequências, que foi resolvida com a eliminação de sítios com mais de $10 \%$ de dados faltantes. 
Os alelos que possuíam mais de dois conjuntos de dígitos e que foram transformados em alelos genéricos nas análises estão listados na Tabela 1A do Apêndice.

\section{4-6- Análise de dados}

\subsection{1- Desvios de Hardy-Weinberg}

Para testar desvios das proporções genotípicas esperadas em equilíbrio de Hardy-Weinberg, foi utilizado o método de Guo \& Thompson (1992).

\subsection{2- Determinação de alelos restritos e com frequência entre as Américas e outras regiões}

Frequências alélicas em outras populações humanas (ver item "bancas de dados acima") foram usadas para identificar alelos geograficamente restritos às Américas, ou com frequência substancialmente maior nessa região em relação à outra. As diferenças em frequências entre regiões foram calculadas dividindo suas frequências médias em ameríndios pela frequência média em não ameríndios. Essa razão permitiu identificar alelos com grandes diferenças de frequência entre populações ameríndias e as demais.

\subsection{3- Diversidade Genética}

Usando os dados de sequencia dos exons 2 dos três loci, foram estimados, com o programa Arlequin versão 3.5 (Excoffier \& Heckel, 2006), as estatísticas sumárias de diversidade: número de sítios polimórficos (S), número de haplótipos (k) a diversidade haplotípica $(\mathrm{H})$ e diversidade nucleotídica $(\pi)$. 
A partir dessas estatísticas sumárias foram feitas estimativas do parâmetro populacional $\theta(4 \mathrm{~N} \mu)$, inferido a partir da diversidade nucleotídica $\left(\theta_{\pi}\right)$, do número de sítios polimórficos $\left(\theta_{\mathrm{s}}\right)$

\subsection{4- Distância Genética}

A diferenciação populacional para $\mathrm{F}_{\mathrm{ST}}$ entre as regiões ou grupos de populações foi estimada através do particionamento hierárquico da variação genética (AMOVA). O intervalo de confiança foi obtido realizando 10.000 bootstraps, em análise implementada no programa Arlequin v 3.5.

A diferenciação das frequências alélicas entre pares de populações foi mensurado por $\mathrm{F}_{\mathrm{ST}}$.

Em um cenário neutro, valores baixos de $\mathrm{F}_{\mathrm{ST}}$ indicam baixa diferenciação populacional, enquanto que valores elevados apontam para uma maior diferenciação.

$\mathrm{Na}$ presença de seleção, valores altos de $\mathrm{F}_{\mathrm{ST}}$ podem indicar pressões seletivas diferentes atuando nas diferentes populações, enquanto que valores baixos podem indicar a ação de pressões seletivas semelhantes ou a ação de seleção balanceadora, que resultariam na manutenção de frequências alélicas semelhantes nas populações (Lewontin \& Krakauer, 1973).

Como a diferenciação entre populações, na ausência de seleção natural, é uma função do tempo de divergência e do tamanho efetivo populacional, a distinção entre as contribuições da história demográfica e seletiva requer comparação da diferenciação e variação em genes HLA com aquela em marcadores supostamente neutros, como os microssatélites.

Para esse fim estimamos valores de $\mathrm{F}_{\mathrm{ST}}$ e de diversidade genética para microssatélites calculados por Nunes (2011) e gentilmente cedidas para as 
comparações. A correlação entre de $\mathrm{F}_{\mathrm{ST}}$ obtidas para HLA e microssatélites foi estimada pelo coeficiente de correlação de Spearman.

\subsection{4- Desvio da neutralidade}

Com o auxílio do programa Arlequim versão 3.11 (Excoffier et al, 2006), foi calculado o $D$ de Tajima, que se baseia na diferença entre as estimativas de $\theta\left(\theta_{\pi \mathrm{e}} \theta_{\mathrm{s}}\right)$. Caso exista diferença significante, descarta-se a hipótese de que a população esteja evoluindo de forma neutra (Tajima, 1989).

Tajima (1989) demonstrou que sob o regime de evolução neutra, espera-se que a diferença entre os estimadores seja zero. Valores negativos são indicativos da presença de vários polimorfismos de baixa frequência nas sequências observadas, que pode ser resultante da ação da seleção direcional, purificadora ou expansão populacional. Valores positivos de D são indicativos de polimorfismos em frequências intermediárias, reflexo tanto da atuação de seleção balanceadora, quanto de gargalo populacional.

Para fazer inferências sobre a história demográfica das populações ameríndias, foi usado o índice de desequilíbrio $\beta$ (KING et al., 2000) Esse índice compara o parâmetro mutacional $\theta(4 \mathrm{Ne} \mu)$, estimada a partir da variância do número de repetições dos alelos de microssatélite, e a taxa de heterozigose esperada (He). Em populações que estão em equilíbrio entre deriva e mutação espera-se que a razão entre $\theta(\mathrm{V}) / \theta(\mathrm{He})$ seja igual a um. Populações que passaram por um gargalo populacional apresentam um desequilíbrio entre a variância no tamanho dos alelos de microssatélites e heterozigose, $\operatorname{com} \beta>1$.

Foram usados os valores de $\beta$ estimados a partir dos microssatélites para realizar análises de correlação entre esse parâmetro demográfico e evidências de 
seleção refletidas no D de Tajima, que, por sua vez, foram estimados para os genes HLA.

Uma correlação positiva significante entre $\mathrm{D}$ de Tajima e $\beta$ é indício de que gargalos populacionais contribuem tanto para o D alto em HLA como para $\beta$ elevado em microssatélites. Já a ausência de correlação entre $\mathrm{D}$ e $\beta$ indica que o padrão de diversidade observado para os genes HLA de classe II é influenciado por fatores adicionais aos gargalos populacionais. 


\section{5- Resultados e Discussão}

\section{1- Desvios de Hardy-Weinberg}

O lócus $H L A-D Q B 1$ foi o único que não apresentou desvios nas proporções de Hardy-Weinberg para qualquer população. Para $H L A-D R B 1$ houve desvios em Waunana $(p=0,004)$, Arara do Laranjal $(p=0,003)$ e Kaingang $(p=0,036)$, mas que perderam significância na correção para múltiplos testes. Para $H L A-D P B 1$ foram observados desvios em Assurini $(\mathrm{p}=0,001)$ e Urubu-Kaapó ( $\mathrm{p}=0,001)$, que não perderam significância mesmo apos a correção para múltiplos testes. As Tabelas com os resultados de análise de desvios de Hardy Weinberg estão no Apêndice 1.

\section{2- Diversidade e Distribuição Geográfica dos Alelos}

Para o conjunto de 307 indivíduos pertencentes a 14 populações da América do Sul, foram observados 17 alelos para o gene $H L A-D R B 1,5$ para $H L A-D Q B 1$ e 7 para $H L A-D P B 1$ (Tabela 6).

As Tabelas 7, 8 e 9 apresentam todos os alelos observados para os 3 loci em estudo, indicando quais alelos estão restritos a populações ameríndias (isto é, não são observados em nenhuma das outras populações humanas não ameríndias presentes nas bases de dados 1 e 2- Tabela 7). As Tabelas também indicam as frequências dos alelos dentro e fora das Américas, bem como a razão entre elas. 
Tabela 6. Frequências alélicas de $H L A-D R B,-D Q B 1$ e-DPB1 nas populações da América do Sul.

\begin{tabular}{|c|c|c|c|c|c|c|c|c|c|c|c|c|c|c|c|}
\hline & ARI & ARL & ARW & $\mathrm{ASN}$ & BKJ & XIK & KMR & PRK & TYR & KAA & $\underline{\mathrm{ZOE}}$ & KWA & MBY & KAG & Média \\
\hline $2 n$ & 30 & 52 & 54 & 44 & 24 & 32 & 32 & 22 & 26 & 44 & 16 & 36 & 26 & 30 & 406 \\
\hline $\mathrm{k}$ & 2 & 6 & 5 & 5 & 7 & 6 & 6 & 5 & 7 & 6 & 5 & 11 & 7 & 7 & 6 \\
\hline $\mathrm{He}$ & 0.48 & 0.75 & 0.68 & 0.76 & 0.85 & 0.8 & 0.63 & 0.78 & 0.66 & 0.64 & 0.81 & 0.89 & 0.76 & 0.72 & 0.72 \\
\hline \multicolumn{16}{|c|}{$H L A-D R B 1$} \\
\hline DRB1*04:11 & 0.37 & 0.44 & 0.00 & 0.34 & 0.13 & 0.13 & 0.06 & 0.18 & 0.58 & 0.57 & 0.25 & 0.06 & 0.39 & 0.00 & 0.29 \\
\hline & 0.63 & 0.00 & & & 0.29 & 0.34 & 0.5 & 0.00 & 0.12 & & 0.00 & 0.2 & & 0.13 & 0.22 \\
\hline КБ & 0.00 & 0.14 & 0.02 & 0.32 & 0.17 & 0.25 & 0.13 & 0.27 & 0.00 & 0.1 & 0.13 & 0.11 & 0.00 & 0.00 & 0.14 \\
\hline & 00 & 0.08 & 0.19 & 0.00 & 0.21 & 0.13 & 0.09 & 0.00 & 0.04 & 0. & 0.00 & 0.11 & 0. & 0.50 & 0.09 \\
\hline & 00 & 0.14 & 0.00 & 0.07 & 0.08 & 0.06 & 0.06 & 0.36 & 0.08 & & 0.00 & 0.1 & & .10 & 0.08 \\
\hline & 00 & 0.12 & 0.1 & & 0.04 & 0.00 & 0.06 & 0.00 & 0.04 & 0.0 & 0.06 & 0.00 & 0.0 & 0.13 & 0.07 \\
\hline & 0.00 & 0.00 & 0.00 & 0.00 & 0.00 & 0.00 & 0.00 & 0.14 & 0.08 & 0.0 & 0.31 & 0.06 & 0.0 & 0.00 & 0.04 \\
\hline & 0.00 & 0.00 & 0.1 & 0.00 & 0.08 & 0.09 & 0.00 & 0.05 & 0.00 & & 0.00 & 0.08 & 0.0 & 0.00 & 0.04 \\
\hline & 0.00 & 0.00 & 0.00 & 0.00 & 0.00 & 0.00 & 0.00 & 0.00 & 0.00 & 0.0 & 0.25 & 0.03 & 0.0 & 0.00 & 0.02 \\
\hline & 0.00 & 0.10 & 0.00 & 0.00 & 0.00 & 0.00 & 0.00 & 0.00 & 0.00 & & 0.00 & 0.11 & 0.00 & 0.00 & 0.01 \\
\hline & 0.00 & & 0.00 & 0.00 & 0.00 & 0.00 & 0.00 & 0.00 & 0.08 & & 0.00 & 0.00 & 0.00 & 0.00 & 0.01 \\
\hline DRB1*11:02 & 0.00 & 0.00 & 0.00 & 0.00 & 0.00 & 0.00 & 0.00 & 0.00 & 0.00 & & 0.00 & 0.00 & 0.00 & 0.07 & 0.01 \\
\hline DRB1*08:06 & 0.00 & 0.00 & 0.00 & 0.00 & 0.00 & 0.00 & 0.00 & 0.00 & 0.00 & 0.00 & 0.00 & 0.00 & 0.04 & 0.00 & 0.00 \\
\hline & & & & & 0.00 & 0.00 & 0.00 & 0.00 & 0.00 & & 0.00 & 0.00 & 0.00 & 0.03 & 0.00 \\
\hline DRB1*04:01 & 0.00 & 0.00 & 0.00 & 0.00 & 0.00 & 0.00 & 0.00 & 0.00 & 0.00 & & 0.00 & 0.00 & 0.00 & 0.03 & 0.00 \\
\hline & 0.00 & 0.00 & 0.00 & 0.00 & 0.00 & 0.00 & 0.00 & 0.00 & 0.00 & & 0.00 & 0.03 & 0.00 & 0.00 & 0.00 \\
\hline DRB1*13:03 & 0.00 & 0.00 & 0.00 & 0.00 & 0.00 & 0.00 & 0.00 & 0.00 & 0.00 & 0.00 & 0.00 & 0.03 & 0.00 & 0.00 & 0.00 \\
\hline
\end{tabular}


Continuação

\begin{tabular}{|c|c|c|c|c|c|c|c|c|c|c|c|c|c|c|c|}
\hline \multicolumn{16}{|c|}{$H L A-D Q B 1$} \\
\hline $2 n$ & 24 & 76 & 52 & 40 & 28 & 18 & 28 & 30 & 26 & 32 & $* * * *$ & 288 & 16 & 10 & 668 \\
\hline $\mathrm{k}$ & 3 & 3 & 4 & 3 & 4 & 3 & 3 & 3 & 3 & 4 & $* * * *$ & 4 & 3 & 3 & 3.31 \\
\hline $\mathrm{He}$ & 0.48 & 0.59 & 0.66 & 0.64 & 0.69 & 0.68 & 0.53 & 0.68 & 0.67 & 0.38 & $* * * *$ & 0.62 & 0.69 & 0.73 & 0.63 \\
\hline DQB1*03:01 & 0.62 & 0.16 & 0.46 & 0.20 & 0.32 & 0.33 & 0.64 & 0.30 & 0.27 & 0.03 & **** & 0.30 & 0.56 & 0.31 & 0.35 \\
\hline DQB1*04:02 & 0.00 & 0.29 & 0.23 & 0.33 & 0.43 & 0.44 & 0.25 & 0.40 & 0.27 & 0.78 & $* * * *$ & 0.40 & 0.17 & 0.25 & 0.33 \\
\hline DQB1*03:02 & 0.38 & 0.55 & 0.29 & 0.48 & 0.21 & 0.22 & 0.11 & 0.30 & 0.46 & 0.16 & $* * * *$ & 0.30 & 0.17 & 0.44 & 0.31 \\
\hline DQB1*03:03 & 0.00 & 0.00 & 0.02 & 0.00 & 0.00 & 0.00 & 0.00 & 0.00 & 0.00 & 0.00 & $* * * *$ & 0.00 & 0.10 & 0.00 & 0.01 \\
\hline DQB1*04:01 & 0.00 & 0.00 & 0.00 & 0.00 & 0.04 & 0.00 & 0.00 & 0.00 & 0.00 & 0.03 & $* * * *$ & 0.00 & 0.00 & 0.00 & 0.01 \\
\hline \multicolumn{16}{|c|}{$H L A-D P B 1$} \\
\hline $2 n$ & 24 & 56 & $* * * *$ & 22 & $* * * *$ & 10 & 18 & 10 & 26 & 16 & $* * * *$ & $k * * *$ & $* * * *$ & ***** & 190 \\
\hline $\mathrm{k}$ & 3 & 4 & $* * * *$ & 4 & $* * * *$ & 4 & 2 & 2 & 5 & 4 & $* * * *$ & $* * *$ & $k * * *$ & $* * *$ & 3.67 \\
\hline $\mathrm{He}$ & 0.62 & 0.69 & $* * * *$ & 0.61 & $* * * *$ & 0.8 & 0.29 & 0.2 & 0.74 & 0.66 & $* * * *$ & $* * * *$ & $* * * *$ & $* * * *$ & 0.61 \\
\hline DPB $1 * 04: 02$ & 0.54 & 0.36 & $* * * *$ & 0.14 & $* * * *$ & 0.40 & 0.83 & 0.90 & 0.31 & 0.56 & $* * * *$ & $* * * *$ & $* * * *$ & $* * * *$ & 0.51 \\
\hline DPB1*14:01 & 0.17 & 0.07 & & 0.23 & & 0.20 & 0.17 & 0.10 & 0.39 & 0.19 & $* * * *$ & $* * * *$ & $* * * *$ & $* * * *$ & 0.19 \\
\hline DPB1*03:01 & 0.29 & 0.39 & $* * * *$ & 0.05 & $* * * *$ & 0.20 & 0.00 & 0.00 & 0.19 & 0.00 & $* * * *$ & $* * * *$ & $* * * *$ & $* * * *$ & 0.14 \\
\hline DPB1*05:01 & 0.00 & 0.00 & $* * * *$ & 0.59 & $* * * *$ & 0.00 & 0.00 & 0.00 & 0.00 & 0.00 & $* * * *$ & $* * * *$ & $* * * *$ & $* * * *$ & 0.07 \\
\hline DPB $1 * 27: 01$ & 0.00 & 0.00 & $* * * *$ & 0.00 & $* * * *$ & 0.20 & 0.00 & 0.00 & 0.08 & 0.13 & $* * * *$ & $* * * *$ & $* * * *$ & $* * * *$ & 0.05 \\
\hline DPB $1 * 04: 01$ & 0.00 & 0.18 & & 0.00 & $* * * *$ & 0.00 & 0.00 & 0.00 & 0.04 & 0.00 & $* * * *$ & $* * * *$ & $* * * *$ & $* * * *$ & 0.03 \\
\hline DPB1*10:01 & 0.00 & 0.00 & $* * * *$ & 0.00 & $* * * *$ & 0.00 & 0.00 & 0.00 & 0.00 & 0.13 & $* * * *$ & $* * * *$ & $* * * *$ & $* * * *$ & 0.02 \\
\hline
\end{tabular}

2n: número de cromossomos; k: número de alelos; He: taxa de heterozigose esperada. ARI- Arara do Iriri; ARL- Arara do Laranjal; ARW-

Araweté; ASN- Assurini;. BKJ- Bakajá Xikrin; XIK- Kayapó Xikrin; KMR- Kayapó Kokaimoro; PRK- Parakanã; TYR-Tiriyó; KAA- UrubuKaapó; KWA- Guarani Kaiowa; MBY- Guarani Mbya; KAG- Kaingang 
Tabela 7. Alelos de HLA-DRB1 observados entre Ameríndios, com suas respectivas frequências em não Ameríndios, bem como a razão entre elas.

\begin{tabular}{|c|c|c|c|}
\hline \multirow{3}{*}{$\begin{array}{c}H L A-D R B 1 \\
\text { Alelos }\end{array}$} & \multicolumn{2}{|c|}{ Frequência dos alelos } & \multirow{3}{*}{ A/NA } \\
\hline & Mundo & América & \\
\hline & $2 n=6532$ & $2 n=2590$ & \\
\hline DRB1*08:07* & 0.0000 & 0.0250 & Restrito á América \\
\hline DRB1*08:05 & 0.0000 & 0.0112 & Restrito á América \\
\hline DRB1*14:13* & 0.0000 & 0.0013 & Restrito á América \\
\hline DRB1*04:13 & 0.0000 & 0.0001 & Restrito á América \\
\hline DRB1*15:05 & 0.0003 & 0.0297 & 91.1 \\
\hline DRB1*08:02* & 0.0012 & 0.1038 & 85.7 \\
\hline DRB1*04:07 & 0.0012 & 0.0898 & 78.1 \\
\hline DRB1*04:11 & 0.0031 & 0.1921 & 61.2 \\
\hline DRB1*03:03 & 0.0001 & 0.0048 & 58.4 \\
\hline DRB1*14:06 & 0.0003 & 0.0190 & 56.3 \\
\hline DRB1*12:03 & 0.0003 & 0.0082 & 26.1 \\
\hline DRB1*14:02 & 0.0124 & 0.0777 & 6.3 \\
\hline DRB1*14:03 & 0.0001 & 0.0008 & 6.2 \\
\hline DRB1*04:04 & 0.0119 & 0.0577 & 4.9 \\
\hline DRB1*03:02 & 0.0095 & 0.0318 & 3.4 \\
\hline DRB1*16:02 & 0.0338 & 0.1126 & 3.3 \\
\hline DRB1*08:04* & 0.0080 & 0.0141 & 1.8 \\
\hline DRB1*04:03 & 0.0102 & 0.0168 & 1.6 \\
\hline DRB1*08:11 & 0.0000 & 0.0001 & 1.5 \\
\hline DRB1*13:12 & 0.0011 & 0.0015 & 1.3 \\
\hline DRB1*14:01 & 0.0295 & 0.0365 & 1.2 \\
\hline DRB1*04:08 & 0.0030 & 0.0036 & 1.2 \\
\hline DRB1*08:01 & 0.0089 & 0.0100 & 1.1 \\
\hline DRB1*04:10 & 0.0036 & 0.0039 & 1.1 \\
\hline DRB1*11:04 & 0.0098 & 0.0085 & 0.9 \\
\hline DRB1*09:01 & 0.0230 & 0.0144 & 0.6 \\
\hline DRB1*04:02 & 0.0081 & 0.0039 & 0.5 \\
\hline DRB1*08:06* & 0.0022 & 0.0012 & 0.5 \\
\hline DRB1*13:23 & 0.0000 & 0.0012 & 0.5 \\
\hline DRB1*08:03 & 0.0742 & 0.0309 & 0.4 \\
\hline DRB1*04:05 & 0.0341 & 0.0122 & 0.4 \\
\hline DRB1*14:04 & 0.0056 & 0.0024 & 0.4 \\
\hline DRB1*04:01 & 0.0204 & 0.0056 & 0.3 \\
\hline DRB1*13:03 & 0.0115 & 0.0029 & 0.3 \\
\hline DRB1*08:08 & 0.0001 & 0.0029 & 0.3 \\
\hline DRB1*11:02 & 0.0076 & 0.0021 & 0.3 \\
\hline DRB1*13:25 & 0.0000 & 0.0020 & 0.3 \\
\hline DRB1*13:09 & 0.0000 & 0.0019 & 0.3 \\
\hline DRB1*11:01 & 0.0580 & 0.0132 & 0.2 \\
\hline DRB1*01:01 & 0.0250 & 0.0041 & 0.2 \\
\hline DRB1*13:07 & 0.0000 & 0.0039 & 0.2 \\
\hline DRB1*14:08 & 0.0234 & 0.0036 & 0.2 \\
\hline DRB1*01:02 & 0.0090 & 0.0017 & 0.2 \\
\hline
\end{tabular}




$\begin{array}{llll}\text { DRB1*11:19 } & 0.0000 & 0.0015 & 0.2 \\ \text { DRB1*15:01 } & 0.0679 & 0.0077 & 0.1 \\ \text { DRB1*03:01 } & 0.0689 & 0.0064 & 0.1 \\ \text { DRB1*13:01 } & 0.0310 & 0.0042 & 0.1 \\ \text { DRB1*13:02 } & 0.0260 & 0.0031 & 0.1 \\ \text { DRB1*14:10 } & 0.0060 & 0.0007 & 0.1 \\ \text { DRB1*16:01 } & 0.0084 & 0.0006 & 0.1 \\ \text { DRB1*11:03 } & 0.0011 & 0.0001 & 0.1\end{array}$

$\mathrm{A} / \mathrm{NA}=$ razão entre as frequências alélicas observadasem Ameríndios e não Ameríndios

Tabela 8. Alelos de HLA-DQB1 observados entre Ameríndios, com suas respectivas frequências em não Ameríndios, bem como a razão entre elas.

\begin{tabular}{|c|c|c|c|}
\hline \multirow{3}{*}{$\begin{array}{c}H L A-D Q B 1 \\
\text { Alelos }\end{array}$} & \multicolumn{2}{|c|}{ Frequência dos alelos } & \multirow{3}{*}{ A/NA } \\
\hline & Mundo & América & \\
\hline & $2 n=3970$ & $2 n=2092$ & \\
\hline DQB1*03:02 & 0.0504 & 0.3518 & 6.9759 \\
\hline DQB1*04:02 & 0.0798 & 0.1687 & 2.1153 \\
\hline DQB1*03:01 & 0.2024 & 0.4227 & 2.0892 \\
\hline DQB1*03:03 & 0.0303 & 0.0126 & 0.4151 \\
\hline DQB1*02:01 & 0.1045 & 0.0322 & 0.3077 \\
\hline DQB1*04:01 & 0.0159 & 0.0022 & 0.1407 \\
\hline DQB1*05:04 & 0.0008 & 0.0001 & 0.1018 \\
\hline DQB1*05:03 & 0.0784 & 0.0041 & 0.0521 \\
\hline DQB1*06:02 & 0.0663 & 0.0030 & 0.0458 \\
\hline DQB1*06:05 & 0.0078 & 0.0002 & 0.0283 \\
\hline DQB1*05:01 & 0.0915 & 0.0021 & 0.0234 \\
\hline DQB1*06:03 & 0.0175 & 0.0002 & 0.0095 \\
\hline
\end{tabular}

$\mathrm{A} / \mathrm{NA=razão} \mathrm{entre} \mathrm{as} \mathrm{frequências} \mathrm{alélicas} \mathrm{observadasem} \mathrm{Ameríndios} \mathrm{e} \mathrm{não} \mathrm{Ameríndios}$

Tabela 9. Alelos de HLA-DPB1 observados entre Ameríndios, com suas respectivas frequências em não Ameríndios, bem como a razão entre elas.

\begin{tabular}{|c|c|c|c|}
\hline \multirow{3}{*}{$\begin{array}{l}H L A-D P B 1 \\
\text { Alelos }\end{array}$} & \multicolumn{3}{|c|}{ Frequência dos alelos } \\
\hline & Mundo & América & A/NA \\
\hline & $2 n=2256$ & $2 n=664$ & \\
\hline DPB 1*27:01 & 0.001 & 0.015 & 13.942 \\
\hline DPB 1*04:02 & 0.075 & 0.577 & 7.725 \\
\hline DPB $1 * 14: 01$ & 0.017 & 0.098 & 5.734 \\
\hline DPB1*10:01 & 0.003 & 0.006 & 2.032 \\
\hline DPB 1*03:01 & 0.061 & 0.109 & 1.794 \\
\hline DPB 1*20:01 & 0.001 & 0.001 & 0.833 \\
\hline DPB 1*19:01 & 0.005 & 0.003 & 0.72 \\
\hline DPB $1 * 04: 01$ & 0.197 & 0.1 & 0.508 \\
\hline DPB 1*15:01 & 0.009 & 0.003 & 0.313 \\
\hline DPB 1*11:01 & 0.008 & 0.003 & 0.305 \\
\hline DPB1*17:01 & 0.011 & 0.003 & 0.243 \\
\hline
\end{tabular}




\begin{tabular}{llll}
$\mathrm{DPB} 1 * 02: 01$ & 0.111 & 0.026 & 0.232 \\
$\mathrm{DPB} 1 * 23: 01$ & 0.002 & 0.001 & 0.221 \\
$\mathrm{DPB} 1 * 05: 01$ & 0.217 & 0.032 & 0.147 \\
$\mathrm{DPB} 1 * 01: 01$ & 0.121 & 0.008 & 0.068 \\
\hline
\end{tabular}

$\mathrm{A} / \mathrm{NA}=$ razão entre as frequências alélicas observadas em Ameríndios e não Ameríndios

Para $H L A-D R B 1$, os alelos mais frequentes foram DRB1*04:11 (frequência 0,29) seguido de DRB1*16:02 (0,22), DRB1*08:07 $(0,14)$ e DRB1*08:02 $(0,082)$. Alguns estudos com populações ameríndias descrevem esses alelos como mais frequentes (Salzano, 2002) (Tsuneto et al., 2003). Quando analisamos somente as populações investigadas no presente estudo, ou seja, as Amazônicas e do Centro Sul, observamos que o único alelo com razão maior do que 20 em relação ao resto do mundo foi o $D R B 1 * 08: 07$. Esse alelo pode ser observado como mais frequente nas populações Assurini $(0,32)$; Bakajá Xikrin $(0,17)$; Kayapó Xikrin $(0,25)$; Kayapó Kokaimoro $(0,13)$; PRK- Parakanã $(0,27)$ (Tabela 6)

Para o gene HLA-DQB1, os alelos mais frequentes foram: DQB1*03:01 $(0,35)$; DQB1*04:02 (0,33); DQB1*03:02 $(0,31)$. Para o gene HLA-DPB1, os alelos mais frequentes foram: DPB1*04:02 $(0,50)$, DPB1*14:01 $(0,19)$ e DPB1*03:01 $(0,14)$. Nenhum dos dois genes apresentou alelos restritos às populações americanas. Para $H L A-D Q B 1$, o alelos mais frequente (DQB1*03:02), foi observado em alta frequencia ns outros trabalho (Salzano 2002).

O $D R B 1 * 08: 07$ é o alelo privado mais frequentemente encontrado nas populações sul ameríndias já investigadas (Solberg et al., 2008) (Epplen et al., 1997). Epplen et al (1997) estudaram um STR no intron 2 do gene HLA-DRB1 e encontraram três alelos de STR associados ao alelo $D R B 1 * 08: 07$. Para os outros alelos $H L A$ $D R B 1 * 08(D R B 1 * 08: 21$ e $D R B 1 * 08: 41)$ apenas um alelo de STR associado foi observado. 
Uma situação similar é observada para o alelo DRB1*14:13, que aparece em altíssima frequencia em populações do centro sul e já foi descrito por Pando et al (1994) e Tsuneto et al (2003) como sendo o mais frequente em populações de índios Guarani e Kaingang. No entanto, o presente estudo não observou esse alelo nas populações de Guarani e Kaingang, provavelmente devido ao reduzido tamanho amostral. Ache foi a única população na qual esse alelo foi detectado, corroborando os resultados obtidos por Tsuneto et al. (2003).

Nossos resultados para $H L A-D R B 1$ documentam de modo claro que é comum para esse lócus haver alelos na América do Sul que não ocorrem em outras populações, ou que possuem grandes diferenças em frequências entre populações. Esses alelos são em alguns casos restritos a algumas populações e em outros partilhados por mais de uma. Além desses alelos há outros que são substancialmente mais frequentes nas Américas que também apresentam frequências alélicas médias elevadas (ex., DRB1*08:02, DRB1*08:07 e DRB1*04:11). Nesses casos uma pergunta recorrente diz respeito ao papel da seleção natural e de processos demográficos como explicações para os padrões de distribuição geográficas. Ao passo que muitos autores argumentam que alelos HLA com frequências elevadas na América são fortes candidatos a seleção, é também plausível que a intensa deriva genética associada à história dessas populações tenha contribuído para os padrões observados. A análise comparativa entre HLA e microssatélites, descrita neste capítulo, terá como objetivo abordar essa questão.

Cabe ressaltar que alelos privados foram detectados nas populações ameríndias desde estudos com eletroforese de proteínas (ex., Thompson e Neel, 1996). Entretanto, estudos feitos com amostras maiores de outras regiões do mundo, e utilizando marcadores moleculares, demonstraram que a ocorrência de alelos privados é de fato 
extremamente rara. Em um conjunto de quase 700 STR, apenas um apresentou um alelo privado em ameríndios (Wang et al., 2007;Schroeder et al., 2009)

Por outro lado, alelos privados são comuns em marcadores do cromossomo Y e mtDNA, capazes de identificar linhagens específicas de Ameríndios (Yang et al., 2011). Esse dado se explica, pois a determinação das linhagens envolve extensos haplotipos, definidos pela combinação de um grande número de SNP ou STR, como é o caso de estudos de mtDNA e cromossomo Y. Nesse caso, a alta variabilidade introduzida pela combinação de SNPs numa escala extensa (abrangendo todas as regiões do genoma mitocondrial e a maior parte da extensão do Y) explicam o padrão de variação endêmica.

Adicionalmente, alelos com razão A/NA elevada são indicativos de alelos autóctones ou quase restritos, excelentes marcadores de Ameríndios. O número alto deles em HLA-DRB1 sugere que forças seletivas podem mantê-los populações em elevada frequência, em comparação com outras populações humanas. Por outro lado, não se pode descartar que muitos alelos possam ter surgido mais de uma vez em populações humanas por conversão gênica, porém apenas em ameríndios eles permaneceram elevados.

A análise da razão A/NA deve ser feita com cautela, uma vez que alguns casos de razões altas ocorrem para alelos extremamente raros, tanto nas Américas como no resto do mundo. Para esses, é possível que ocorra uma razão alta, mas ele é estatisticamente pouco confiável (em função da baixa amostragem) e também biologicamente menos relevante (alelos geograficamente restritos, porém comuns são aqueles que representam possíveis candidatos a eventos seletivos locais). Uma limitação, que conduz a uma interpretação mais cuidadosa: a presença de alelos com 
baixa frequencia em poucos indivíduos e que não foram observado nas populações do resto do mundo, pode confundir a classificação de alelos privados, já q esses encontramse em baixa frequencia para o mundo todo

\section{3 - Variação genética em genes HLA.}

A variabilidade genética em genes HLA é o resultado da interação entre processos demográficos e seletivos. Uma vez que há forte evidência de que genes HLA em humanos estão sob seleção natural, há a expectativa de que a variação genética em genes HLA não reflita aspectos da história demográfica das populações. Entretanto, estudos prévios mostram que diversas assinaturas genéticas, características de efeitos demográficos, são visíveis em genes HLA (Meyer et al., 2006).

Nós investigamos de que modo a variação genética nos genes HLA de classe II foi moldada pela história demográfica das populações. Nossa primeira abordagem consistiu em testar um padrão extremamente geral, abundantemente documentado em estudos usando grandes painéis de marcadores nucleares, que é o decréscimo de variação genética de populações humanas que habitam regiões do mundo mais distantes da África, e que, portanto estiveram sujeitas a mais gargalos populacionais sucessivos em sua história migratória, até atingir sua localidade atual(ex., Rosenberg et al., 2003, Prugnolle et al., 2005). Uma vez que dispúnhamos de um número limitado de amostras populacionais de diferentes regiões do mundo, optamos por investigar o padrão mais extremo, que é o das diferenças entre a variabilidade genética em populações indígenas do Leste da América do Sul, por nós genotipadas, e populações de outras regiões do

mundo. Para realizar essa comparação reunimos populações Africanas, Europeias e Asiáticas num único grupo (totalizando 7, 13 e 16 populações para HLA-DPB1, HLA- 
DQB1 e HLA-DRB1, respectivamente), cuja diversidade foi contrastada com o de 9, 13 e 14 populações do Leste da América do Sul, para os mesmos três loci (Figua 9). A opção de fazer o contraste entre esses dois grandes grupos foi devido ao número pequeno de amostras em várias regiões, e padrões de diversidade muito sujeitos a deriva em populações insulares (por exemplo, no sudoeste pacífico). O uso desse grupo heterogêneo é biologicamente justificado pelo fato de que estudos anteriores encontraram, para marcadores neutros, uma redução da diversidade genética em ameríndios em relação a populações de todas as demais regiões geográficas (Prugnolle et al., 2005).
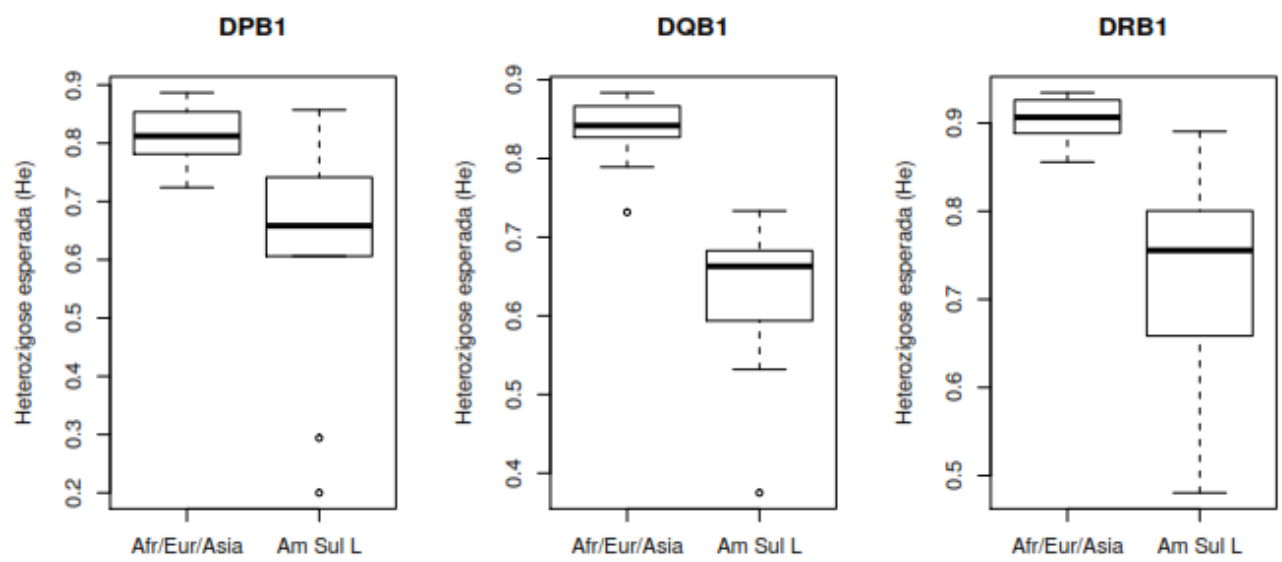

Figura 9. Box Plot das taxas de heterozigose esperada para as populações da America do Sul versus populações do resto do mundo (Afr/Eur/Asia) para genes HLA de classe II.

Em todos os loci, encontramos uma diversidade genética significativamente reduzida em populações do Leste da América do Sul, em relação ao grupo de populações Africanas, Europeias e Asiáticas (Figura 9), teste de somas de ranks de Wilcoxon com $\mathrm{p}=0,016, \mathrm{p}<0.001$ e $\mathrm{p}<0,001$, para DPB1, DQB1 e DRB1, 
respectivamente). Esse resultado é consistente com a redução de diversidade genética vista na América do Sul de modo geral, e documenta os fortes efeitos da história demográfica mesmo sobre os genes HLA.

\section{4- Relação entre He em genes HLA e em microssatélites}

A seguir, investigamos os efeitos da história demográfica sobre genes utilizando uma segunda abordagem. Uma vez que dispomos de dados de genotipagem para 61 marcadores microssatélites nas amostras do Leste da América do Sul, podemos investigar se, para as populações dessa região do mundo, há uma correlação entre diversidade nesses dois sistemas genéticos (microssatélites espalhados pelo genoma e genes HLA).
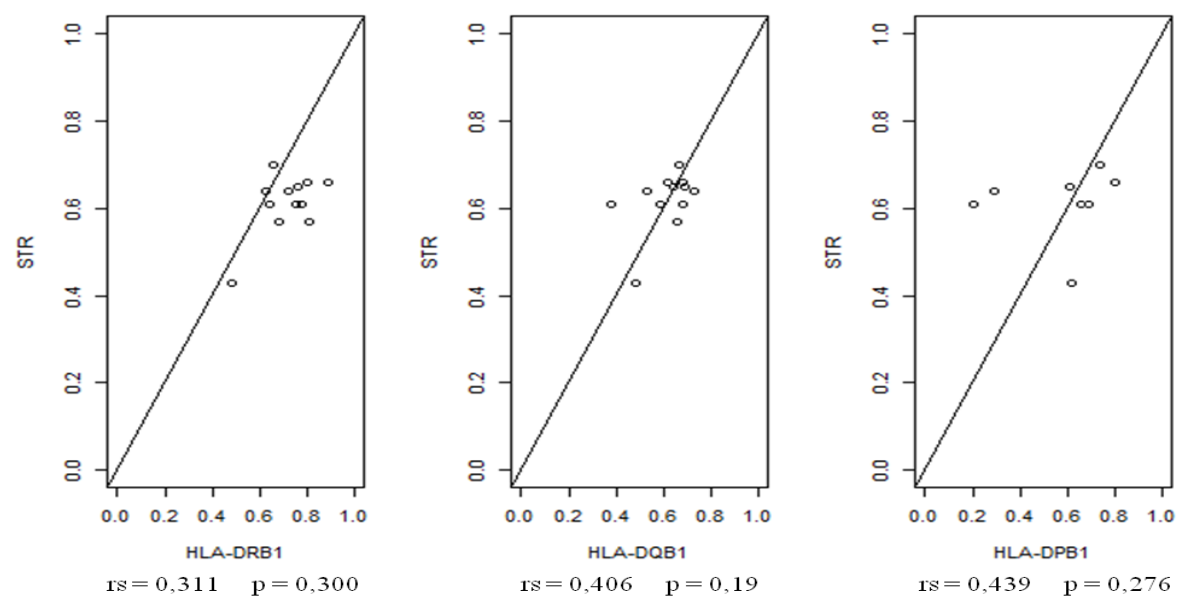

Figura 10:: Correlação entre a taxa de heterozigose esperada de STR genômicos (Nunes, 2012) e genes HLA de classe II.

Para todos os três loci encontramos uma correlação positiva, porem não significante. Essas correlações são relativamente modestas, algo esperado em 
decorrência de estarmos utilizando um pequeno grupo de populações que, como documentamos acima, possui baixa variabilidade genética (Figura 10).

Alternativamente, a história seletiva dos genes HLA pode ter influenciado a baixa correlação entre diversidades genéticas de STR e esses loci.

\section{5- Diferenciação populacional}

Nós investigamos a diferenciação populacional para os genes HLA de duas formas. Primeiro, inserimos os dados num contexto global, contrastando-os entre diferentes classes de marcadores e agrupamentos populacionais. Segundo, realizamos análises focadas exclusivamente no Leste da América do Sul, região para a qual temos dados pareados para genes HLA e microssatélites.

Inicialmente comparamos os dados de diferenciação genética, medida com $\mathrm{F}_{\mathrm{ST}}$, para diferentes conjuntos de genes, em diversos agrupamentos populacionais (Tabela 10). Nós não encontramos, em qualquer uma das análises, um forte indício de que os genes HLA apresentam níveis de diferenciação reduzidos (como é proposto por alguns modelos dos efeitos de seleção balanceadora sobre diferenciação genética), e em alguns casos encontramos valores relativamente altos em relação à diferenciação vista para outros marcadores.

Tabela 10. Estimativas de diferenciação populacional para os 61 STR genômicos e os três genes de classe II estudados.

\begin{tabular}{|c|c|c|c|c|c|c|c|c|c|c|c|c|}
\hline & \multicolumn{3}{|c|}{ STR } & \multicolumn{3}{|c|}{$H L A-D R B 1$} & \multicolumn{3}{|c|}{$H L A-D Q B 1$} & \multicolumn{3}{|c|}{$H L A-D P B 1$} \\
\hline Reg & $\mathrm{n}$ & $\mathrm{F}_{\mathrm{ST}}$ & $p$ & $\mathrm{n}$ & $\mathrm{F}_{\mathrm{ST}}$ & $p$ & $\mathrm{n}$ & $\mathrm{F}_{\mathrm{ST}}$ & $p$ & $\mathrm{n}$ & $\mathrm{F}_{\mathrm{ST}}$ & $p$ \\
\hline $\mathrm{Mu}$ & 90 & 0,068 & 0,000 & 72 & 0,118 & $\overline{0,000}$ & 43 & 0,152 & 0,000 & 29 & 0.159 & 0,000 \\
\hline Áfr & 8 & 0,025 & 0,000 & 9 & 0,033 & 0,000 & 7 & 0,031 & 0,0 & 3 & 0.01 & 0,001 \\
\hline & 9 & 0,005 & 1,000 & 4 & 0,016 & 0,000 & 3 & 0,013 & 0,0 & 3 & 0,001 & 0,775 \\
\hline Centro Sul & 9 & 0,011 & 0,730 & 7 & 0,067 & 0,000 & 6 & 0,054 & 0,000 & 3 & 0,065 & 0,000 \\
\hline
\end{tabular}


Asia

\begin{tabular}{lcccccccccccc} 
Oceania & 2 & 0,082 & 0,000 & 4 & 0,178 & 0,000 & 4 & 0,181 & 0,000 & 4 & 0,112 & 0,000 \\
América & 41 & 0,092 & 0,000 & 46 & 0,161 & 0,000 & 22 & 0,221 & 0,000 & 16 & 0,123 & 0,000 \\
$\begin{array}{l}\text { América } \\
\text { do Norte }\end{array}$ & 3 & 0,035 & 0,000 & 10 & 0,163 & 0,000 & 8 & 0.271 & 0,000 & 4 & 0,091 & 0,000 \\
$\begin{array}{l}\text { América } \\
\text { Central }\end{array}$ & 6 & 0,041 & 0,000 & 6 & 0,061 & 0,000 & 1 & $* * * *-$ & $* * * *$ & 1 & $* * * *$ & $* * * *$ \\
$\begin{array}{l}\text { Oeste } \\
\begin{array}{l}\text { América } \\
\text { do Sul }\end{array}\end{array}$ & 12 & 0,059 & 0,000 & 12 & 0,131 & 0,000 & 0 & $* * * *$ & $* * * *$ & 0 & $* * * *$ & $* * * *$ \\
$\begin{array}{l}\text { Leste } \\
\text { América } \\
\text { do Sul }\end{array}$ & 20 & 0,127 & 0,000 & 17 & 0.153 & 0,000 & 13 & 0.11 & 0,001 & 11 & 0.102 & 0,000 \\
\hline
\end{tabular}

$\mathrm{n}=$ numero de populações $* * * *_{-}$Grupo d populações não foi testado-

Entretanto, a principal dificuldade que enfrentamos é a de que os conjuntos de populações estudadas para genes HLA nem sempre correspondem às estudadas para microssatélites, e sabe-se que a composição do grupo (isto é, quantas e quais populações o integram) tem um forte efeito sobre a medida de diferenciação. Além disso, comparações diretas entre $\mathrm{F}_{\mathrm{ST}}$ e microssatélites são difíceis de interpretar uma vez que o $\mathrm{F}_{\mathrm{ST}}$ é uma medida extremamente sensível ao nível de variação intrapopulacional, e este difere de modo marcante entre genes HLA e microssatélites (sendo maior em genes HLA). De fato, a variabilidade interpopulacional, como a estimada por $F_{\text {ST }}$, é reconhecidamente dependente da variabilidade intrapopulacional (diversidade genética). A correlação entre distancias genéticas e diversidade genética foi inicialmente descrita por Livshits \& Nei, (1990.) e sua relação em populações ameríndias confirmada por Guerreiro et al (1993), ambos os estudos usando marcadores proteicos clássicos. Posteriormente Bowcock et al. (1994) também ressalta o efeito da diversidade genética em estimativas de distância genética obtidas de marcadores STR.

No contexto de nossos resultados, esse efeito não explica os maiores valores de

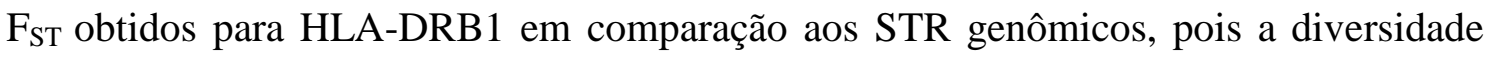


genética observada para STR genômicos $(0.64)$ foi menor que a observada para HLADRB1 (0.75; Teste de Wilcoxon, $\mathrm{p}<0,0001)$. Assim, a influência da diversidade genética seria no sentido de diminuir os valores de $\mathrm{F}_{\mathrm{ST}}$ de HLA-DRB1 em relação ao genômico.
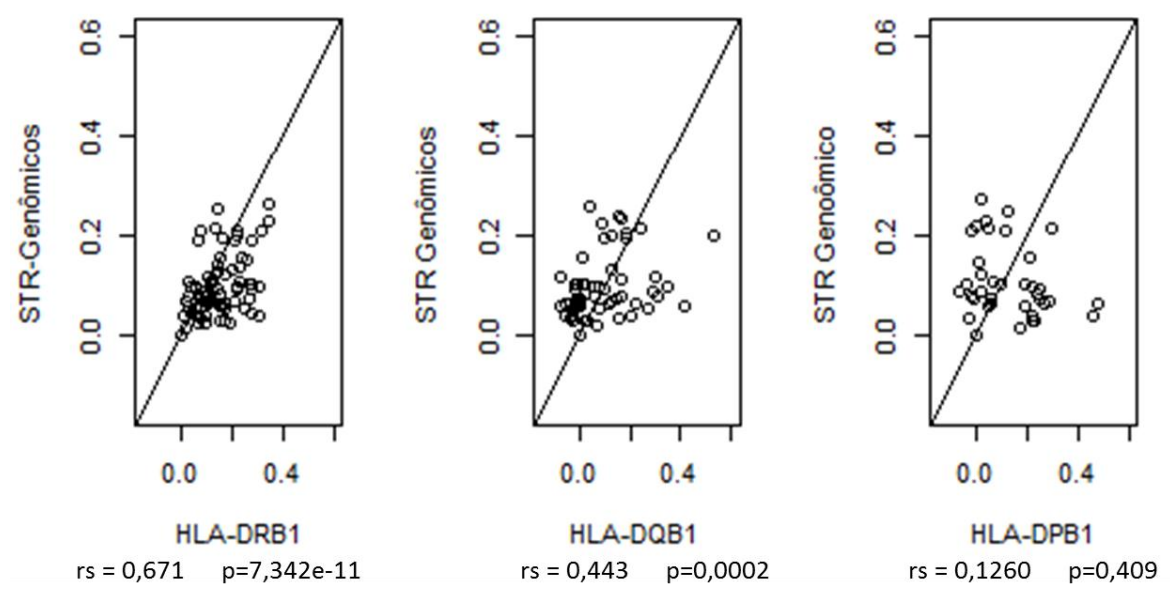

Figura 11: Correlação entre os $\mathrm{F}_{\mathrm{ST}}$ par a par obtidos para os STR genômicos (Nunes, 2012) e genes HLA de classe II nas populações do Leste da América do Sul

Realizamos uma segunda abordagem, que consistiu em comparar medidas de diferenciação genética para todos os pares de populações para as quais dispúnhamos de dados para HLA e microssatélites. Essas análises revelaram uma correlação positiva significativa para $H L A-D Q B 1$ e $H L A-D R B 1$ (rs=0,617, $\mathrm{p}<0,0001$ e rs=0,4432, $\mathrm{p}=0,0002$, respectivamente) (Figura 11), mas não para $H L A-D P B 1(\mathrm{rs}=0,136, \mathrm{p}=0,409)$.

Esse resultado ilustra como a diferenciação entre populações, um processo demográfico, tem um forte reflexo sobre a diferenciação em genes HLA nos lóci DRB1 e $D Q B 1$, como havíamos argumentando acima. Para o lócus $D P B 1$ não há correlação significativa, resultado que é particularmente surpreendente uma vez que esse é o lócus 
para o qual há menor evidência de seleção balanceadora, e para o qual esperaríamos uma congruência maior com os marcadores microssatélites.

\section{6- Desvios de neutralidade}

A análise de desvios da hipótese nula de neutralidade foi testada utilizando o D de Tajima. Como era esperado para um estudo de genes HLA, encontramos valores de D positivos, e significativos em 5 de 7,11 de 12,8 de 14 populações testadas para $H L A$ $D P B 1,-D Q B 1$ e -DRB1, respectivamente. Em um único caso (HLA-DPB1 em Parakanã) o D foi negativo e significativo, indicando seleção direcional. Em todos os outros casos há evidência de seleção balanceadora, mesmo quando significância estatística não foi atingida (Tabela 11)

Tabela 11. Valores de D de Tajima para as populações do Leste da América do Sul

\begin{tabular}{lcccccc}
\hline & \multicolumn{2}{c}{ HLA-DRB1 } & \multicolumn{2}{c}{ HLA-DQB1 } & \multicolumn{2}{c}{ HLA-DPB1 } \\
\hline & D Tajima & $p$ & D Tajima & $p$ & D Tajima & $p$ \\
\hline Arara do iriri & 3.178 & 1 & 2.617 & 0.997 & 3.062 & 1 \\
Arara do & 2.899 & 0.999 & 3.235 & 1 & 3.244 & 1 \\
Laranjal & & & & & & \\
Arawete & 2.359 & 0.994 & 2.678 & 0.998 & 1.711 & 0.977 \\
Assurini & 2.886 & 0.999 & 3.169 & 1 & $* * * *$ & $* * * *$ \\
Bakajá Xikrin & 1.38 & 0.942 & 3.278 & 1 & $* * * *$ & $* * * *$ \\
Kayapo Xikrin & 1.611 & 0.965 & 3.149 & 1 & $* * * *$ & $* * * *$ \\
Kayapo & 1.376 & 0.939 & 1.998 & 0.985 & 0.044 & 0.568 \\
Krokaimoro & & & & & & \\
Parakanã & 0.87 & 0.849 & 3.498 & 1 & -1.989 & 0.003 \\
Tiriyo & 1.002 & 0.882 & 2.441 & 0.997 & 2.126 & 0.989 \\
Urubu Kaapo & 1.033 & 0.89 & 0.406 & 0.709 & $* * * *$ & $* * * *$ \\
Zo'e & 2.514 & 0.999 & $* * * *$ & $* * * *$ & $* * * *$ & $* * * *$ \\
Guarani Kaiowa & 1.409 & 0.941 & 2.869 & 0.996 & $* * * *$ & $* * * *$ \\
Guarani Mbya & 1.288 & 0.926 & 1.867 & 0.984 & $* * * *$ & $* * * *$ \\
Kaingang & 0.931 & 0.869 & 2.525 & 1 & $* * * *$ & $* * * *$ \\
\hline
\end{tabular}


A seguir, nós comparamos os valores de $D$ de Tajima entre regiões do mundo, como foi feito para os valores de heterozigose. Apesar de haver uma tendência de valores de $D$ menores para o Leste da América do Sul, com medianas nessa região sendo menores, a diferença entre África/Europa/Ásia só atingiu significância para HLADRB1 ( $p<0,01$, teste de Wilcoxon) (Figura 12). Esse resultado sugere que apesar da redução de diversidade no Leste da América do Sul ser marcante (Figura 9), a perda de variação não resultou numa redução significativa da variação que é medida pelo de $D$ de Tajima, tanto para HLA-DPB1 como HLA-DQB1. Esse resultado é explicado pelo fato da estatística $D$ ser sensível ao grau de diferenciação entre os alelos que segregam numa amostra. Mesmo com a redução de diversidade genética, permanecem segregando nas populações ameríndias alelos altamente diferenciados, contribuindo para o D elevado.
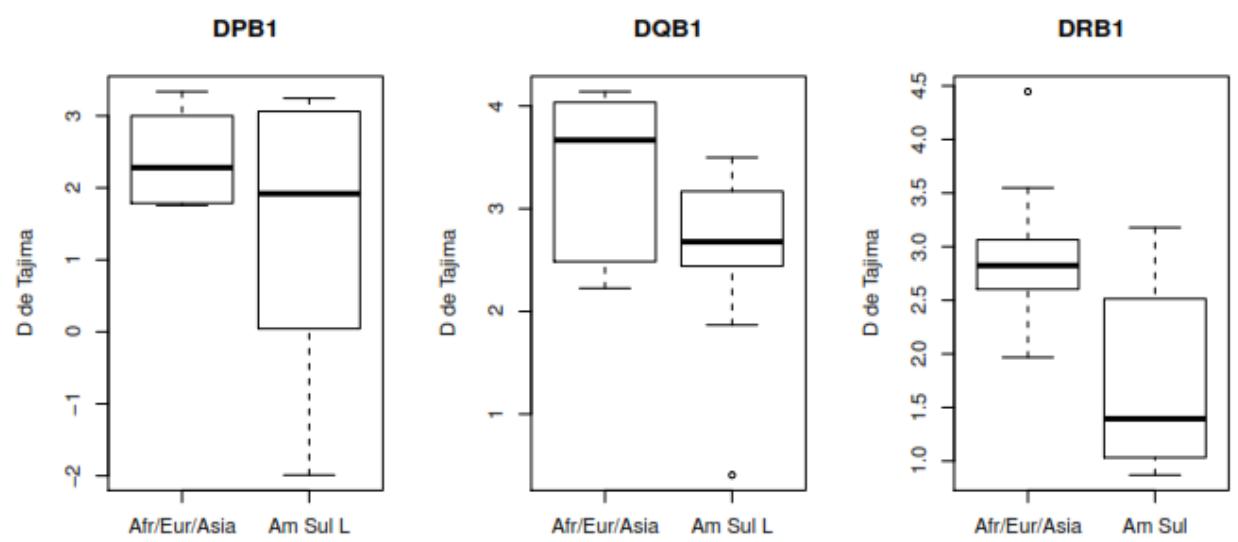

Figura 12: Box Plot do valores de D de Tajima para as populações da America do sul versus populações do resto do mundo (Afr/Eur/Asia) para genes HLA de classe II.

Finalmente, realizamos a comparação entre D e uma medida que é sensível à história demográfica da população, e pode ser aplicada aos microssatélites. A estatística usada foi o valor de $\beta$, que é sensível a eventos demográficos recentes, como gargalos populacionais. Na comparação do D de Tajima estimado para os genes HLA com a $\beta$ 
dos microssatélites genômicos, observamos uma ausência de correlação (correlação de Spearman; HLA-DRB1 p=0,36; HLA-DQB1 $\mathrm{P}=0,31 ; H L A-D P B 1 \mathrm{p}=0,24)$ (Figura 13).
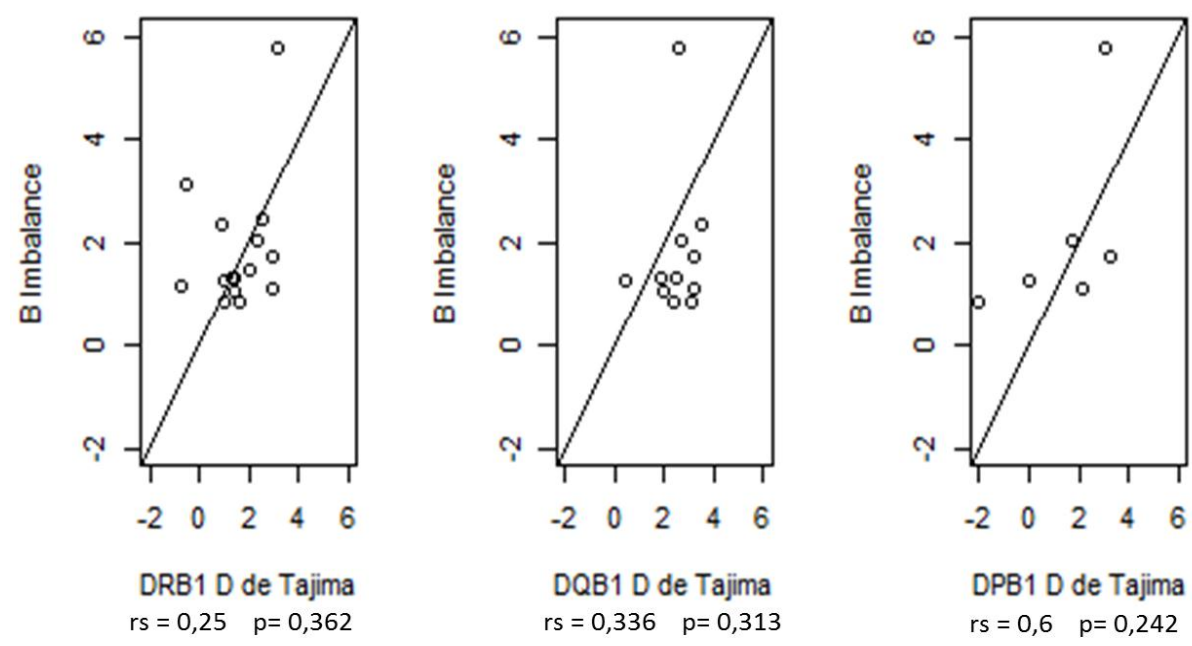

Figura 13: Correlação entre os valores de D de Tajima, estimados pelos genes HLA de classe II, e Diferenciação $\beta$, estimada para os microssatélites genômicos

Neste capítulo realizamos uma análise populacional de genes HLA de classe II em populações ameríndias da América do Sul. Esses genes desempenham papel crucial no funcionamento do sistema imune, e há abundantes evidências prévias de que estão sob seleção. Entretanto, havia poucos estudos com populações da América do Sul, onde a histórica demográfica peculiar, envolvendo drásticos gargalos populacionais (Hey, 2005) pode ter interferido com o efeito da seleção natural. De fato, Solberg et al. (2008), numa meta-análise, demonstraram que a América do Sul era a região com uma das mais baixas proporções de populações com desvios significativos de neutralidade (testadas pelo teste de Ewens-Watterson), para os genes DRB1, DQB1 e DPB1. 
Neste estudo revisitamos essas questões, com algumas importantes inovações. Primeiro, realizamos a genotipagem através de sequenciamento de DNA, ao invés de inferir os alelos HLA usando métodos que efetivamente só sondam um subconjunto dos sítios polimórficos (como foi o caso dos dados usados por Solberg et al, 2008). Isso nos permite aplicar testes de neutralidade que utilizam informaação sobre variação ao nível molecular, aumentando o poder estatístico do teste (como é o caso do D de Tajima). Em segundo lugar, genotipamos um grande número de populações num único estudo, permitindo análises comparativas entre amostras geradas segundo um mesmo conjunto de critérios metodológicos. Estudos meta-analíticos enfrentam a dificuldade de agregar dados gerados em diferentes momentos e com diferentes métodos, que muitas vezes pode gerar aparente diferenças genéticas que na realidade resultam de mudanças metodológicas. Finalmente, nosso estudo conta com uma genotipagem de um painel de 61 microssatélites autossômicos não-ligados ao MHC e não ligados entre si, oferecendo assim um controle neutro para a história demográfica dessas populações, em relação ao qual os resultados obtidos para os genes HLA podem ser comparados.

Nossos resultados indicam que os genes de HLA de classe II nas populações Ameríndias apresentam uma hierarquia de polimorfismo igual ao de outras regiões do mundo, com DRB1 > DQB1 > DPB1. Para todos os três loci as estimativas de He entre ameríndios é significativamente mais baixa do que em outras regiões do mundo, mostrando uma concordância com expectativas demográficas. Nossos resultados também mostram uma concordância entre genes HLA e microssatélites, consistente com um partilhamento de processos demográficos que mondaram a variação e diferenciação, quando comparamos os valores de Fst para todos os pares de populações, para os dois tipos de marcadores (correlações significativas entre a diferenciação populacional 
medida para microssatélites e genes HLA, tanto para DRB1 como DQB1). Já a correlação entre a taxa de heterozigose de microssatélites e de HLA, apesar de sempre positiva, não foi significativa, diferente do resultado obtido usando uma amostra com populações de várias regiões (Meyer et al., não publicado). Esse resultado sugere que, apesar da história demográfica influenciar os níveis de variação tanto de genes HLA como de microssatélites, o fato de todas amostras terem níveis de variação semelhantes diminui o poder do teste para encontrar uma correlação entre a diversidade nos dois tipos de marcadores.

Diferentemente do teste de neutralidade baseado no modelo de infinitos alelos implementado por Solberg et al., (2008), nós detectamos desvios de neutralidade na maior parte das populações (71, 91 e 57\% para DPB1, DQB1, e DRB1, respectivamente), usando a estatística D de Tajima.

Entretanto, diferentemente do que vimos para a taxa de heterozigose, os valores de D são apenas fracamente correlacionados com grandes agrupamentos continentais (com diferenças não significativas entre Eur/Afr/Asia e América para DPB1 de DQB1). Esse resultado ilustra como, apesar do bem documentado efeito da história demográfica sobre estatística com o D-Tajima (Stajich \& Hahn, 2005), a seleção natural que vem atuando sobre genes HLA em grandes escalas de tempo resultou em alelos altamente divergentes. Essa diferenciação contribui para a significância do teste, e não é sensível aos eventos demográficos mais recentes, que resultam na perda de heterozigose em ameríndios.

No teste de correlação dos valões de $\mathrm{D}$ com o $\beta$, é possível interpretar a ausência de correlação entre os valores das duas estatísticas como um indício de que, apesar dos fortes sinais observados da influência da história demográfica, ou seja, que 
existe um sinal de seleção balanceadora remanescente visível como consequência da alta diferenciação entre os alelos HLA.

Nosso trabalho também permitiu quantificar a prevalência de alelos restritos às Américas ou com grandes diferenças de frequência entre as regiões. Em DRB1 encontramos o maior número de alelos com altas razões A/NA, porém apenas 3 dos alelos com A/NA maior que 5 tinham frequências acima de 3\%. Associado ao fato de que o DRB1 é o lócus mais polimórfico dentre os de classe II (fato que por si só já aumenta a probabilidade de haver alelos exclusivas de uma região), sugerimos que os dados a respeito da existência de alelos de alelos restritos à América do Sul, por si só não implicam que a seleção natural foi o processo que explica sua distribuição.

Em conjunto, nossos resultados mostram que a seleção natural moldou aspectos da variação genética em genes HLA (visível em valores de D significativos e uniformemente positivos, com exceção de uma amostra para DPB1), mas que a diferenciação em HLA-DRB1 e DQB1 é significativamente correlacionada à de microssatélites para as mesmas amostras, argumentando que para essa componente da variação (a diferenciação entre populações) processos demográficos exerceram um efeito que não foi revertido ou substancialmente alterado pela seleção natural. 


\section{Capitulo 2. Investigação de sinais seleção recente nas proporções de ancestralidade do MHC da população miscigenada de Belém}

\section{1- Introdução}

Grande parte da pesquisa em genética evolutiva consiste em compreender quais diferenças entre populações ou espécies resultam do acúmulo passivo de mutações sem efeitos seletivos (evolução neutra, que se dá por fatores estocásticos), e quais resultam das vantagens seletivas associadas a certas mutações (a evolução adaptativa, que se dá por seleção natural). A partir do momento que regiões sob seleção natural são identificadas no genoma, essas passam a serem alvos de estudos sobre a história adaptativa de espécies e populações (Meyer e Thomson, 2001).

Nos últimos anos, vários estudos realizaram buscas no genoma por sinais de seleção e identificaram diversos genes e regiões genômicas com sinais de pressão seletiva (Akey et al., 2004, Bustamante et al., 2005; Kelley et al., 2006; Nielsen et al., 2005; Nielsen et al, 2005; Nielsen et al., 2009; Sabeti et al., 2002; Sabeti et al., 2006, Voight et al., 2006, Wang et al., 2007).

A maioria desses estudos foi desenvolvida a partir de duas abordagens clássicas. Uma fundamenta-se na escolha de genes candidatos a estarem sob seleção para então empregar uma análise populacional com o objetivo de compreender como a seleção está agindo. A outra abordagem baseia-se na varredura genômica, buscando a identificação de sinais de seleção em regiões ou genes. A utilização de populações miscigenadas nessas abordagens introduz complicações e desafios para as análises ( Nielsen et al., 2005). Há, entretanto, uma abordagem que permite a detecção de sinais de seleção 
recente em populações miscigenadas e ela consiste da comparação das proporções de ancestralidade observadas em regiões supostamente neutras com regiões que estejam sob seleção (Long, 1991). A hipótese é a deque as regiões genômicas sob seleção apresentariam desvios nas proporções de ancestralidade parental quando comparadas com o restante do genoma (Tang et al., 2007) , 2008, (Basu et al., 2008) et al., 2008).

Dentre os genes que apresentam evidências de seleção nos estudos de varredura genômica, os do sistema imune aparecem como sendo alvos da atuação de seleção positiva ou diversificadora (Hughes et al., 2005). Os genes HLA do Complexo Principal de Histocompatibilidade (MHC) apresentam um conjunto de evidências que suportam a hipótese de seleção do tipo balanceadora atuando na modulação de sua diversidade genética acima dos níveis esperados sob neutralidade, como por exemplo: alta diversidade alélica, elevada taxa de substituição não sinônima, um grande número de alelos em frequências intermediárias, e um alto nível de desequilíbrio de ligação. (Hughes et al., 2005; Meyer e Thomson, 2001).

A função das moléculas codificadas por esses genes é a de apresentar antígenos próprios e não-próprios (ex: antígenos de bactérias e outros agentes patogênicos e ambientais) processados pelas células aos linfócitos $\mathrm{T}$, como parte do mecanismo de identificação e resposta a antígenos (Snustad e Simmons, 2001; Stern et al., 1994). Efeitos seletivos resultantes de variação ambiental como, por exemplo, presença, ausência ou diversidade genética de determinados patógenos, parece ser uma das forças principais que dirigem a diversidade desse complexo gênico (Prugnolle et al., 2005).

Diante disso, surge a seguinte pergunta: a pressão seletiva sobre os genes $H L A$ levaria a diferenças nas estimativas de ancestralidade obtidas no MHC em relação á média genômica? Uma resposta afirmativa a essa questão indicaria que, além da 
seleção balanceadora, esses genes estão sob regime de seleção que leva ao estabelecimento de alelos adaptados às condições ambientais locais de maneira rápida. No contexto da reestruturação das populações nas Américas após a colonização europeia e africana, essa questão tem uma importância fundamental: a de questionar se a diversidade genética de $H L A$ em populações americanas sofreu seleção nos últimos 500 anos de história.

\section{1- Neutralidade versus Seleção}

Há diversos métodos para buscar genes sob seleção natural, incluindo desde estudos em escala filogenética, como os métodos baseados em dN/dS (Clark et al., 2003), métodos que comparam polimorfismo e divergência, como as abordagens que usam o teste de MacDonald-Kreitman (Bustamante et al., 2005). Há também diversos métodos populacionais, que analisam a variação dentro de populações usando estatísticas sumárias, que são capazes de captar desvios do espectro de mutações (Andrés et al., 2009), que buscam regiões com blocos de haplótipos longos, presumivelmente gerados por seleção positiva recente (Sabeti et al., 2006; Voight et al., 2006) além, de métodos que buscam genes com altos valores de diferenciação interpopulacional, o que indicaria adaptação local a diferentes ambientes (Akey et al., 2002).

Geralmente esses estudos usam populações humanas relativamente livres de miscigenação, pois a história demográfica de populações miscigenadas introduz consideráveis complicações na interpretação dos métodos descritos acima (ex. Nielsen et al., 2005). Como foi dito anteriormente, a análise de populações miscigenadas permite a busca de regiões que possam ter passado por seleção recente, ou pelo menos tenha sido coincidente com o período de início da miscigenação (Tang et al., 2007). A 
busca de genes sob seleção usando populações miscigenadas é baseada na premissa de que as populações parentais possuem diferenças genéticas entre si. Quando ocorre a miscigenação, forma-se uma nova população que é uma mistura das parentais. Para regiões do genoma que não estão sob seleção, as populações miscigenadas apresentam frequências alélicas proporcionais à contribuição das populações fundadoras que participaram da sua formação (Long et al., 1991; Sabeti et al., 2002). Quando há um desvio significativo dessas proporções, isto pode estar refletindo atuação de seleção natural, favorecendo ou depreciando um haplótipo parental (ex: Tang et al., 2007).

O estudo de Tang et al. (2007) foi um dos primeiros a realizar uma varredura genômica em populações miscigenadas. Seu objetivo foi examinar as proporções das três ancestralidades presentes na população de Porto Rico (europeia, africana e nativoamericana) utilizando mais de 100.000 SNP (Single Nucleotide Polimorphism) espalhados pelo genoma. Seus resultados apontaram para uma alta proporção de ancestralidade europeia. Entretanto, ao fazer o contraste da proporção de ancestralidade média do genoma de cada SNP em relação à média genômica, alguns apresentaram desvio significativo, dentre eles os localizados no MHC.

Após um estudo mais detalhado usando os genótipos de genes $H L A$ na população estudada, os autores identificaram, de fato, um aumento na proporção de ancestralidade africana atrelada aos alelos $H L A$ em relação ao restante do genoma (de $17 \%$ de contribuição o genoma para $30 \%$ com os genes $H L A)$. A interpretação dada pelos autores foi a de que as características ambientais favoreceram a manutenção dos alelos africanos para os genes $H L A$ na população de Porto Rico.

No caso das populações miscigenadas do Norte do Brasil, a relação entre a miscigenação observada nos genes $H L A$ e no restante do genoma é particularmente 
interessante, pois elas apresentam uma alta contribuição ameríndia (Santos et al., 2010). A busca por evidências de seleção, usando a abordagem de miscigenação, constituirá uma forma de sondar as pressões seletivas recentes nessa região geográfica, para a qual há resultados com populações nativas que indicam haver fortes pressões seletivas, que teriam resultado numa alta incidência de alelos endêmicos de $H L A$ na América do Sul (Belich et al., 1992; Francisco, 2009).

\section{2- Formação da população de Belém}

A população brasileira é uma das mais heterogêneas e miscigenadas do mundo. Sua formação iniciou-se no início do século XVI, com a chegada dos primeiros colonos portugueses à costa do nordeste. Aqui, os portugueses se depararam com uma surpreendente população de mais de 2,5 milhões de nativos-americanos, distribuídos em diferentes etnias e grupos linguísticos (Cunha, 1995; Klein, 1999). Atualmente, a estimativa é de que existam apenas 450.000 indivíduos nativos americanos sobreviventes (IBGE- Censo 2010). A partir do século XVI até o final do século XIX, mais de 3,5 milhões de africanos foram trazidos forçadamente, de diferentes regiões da África Subsaariana, para o Brasil com o objetivo de servirem como mão de obra escrava (Curtin, 1969).

A partir do século XIX até metade do século XX, o Brasil recebeu imigrantes de outros países europeus, além de Portugal. Esses migrantes ocuparam, preferencialmente, a região sul e sudeste do país e devido a políticas de ocupação do território, o processo de miscigenação no Brasil se deu de maneira bastante diferente entre as regiões do país (Pena et al., 2011). 
Nesse contexto a população de Belém surgiu, fundamentalmente, como resultado da miscigenação entre ameríndios, europeus portugueses e africanos da costa leste (Simonian, 2010; Salles, 2005). A população ameríndia que ocupava a região da cidade de Belém era composta principalmente por índios Tupinambás, pertencentes ao grupo linguístico Tupi (Simonian, 2010).

A chegada dos Portugueses à Baía do Guajará se deu em janeiro de 1616, em uma incursão comandada por Francisco Caldeira Castello Branco, que fundou às margens do Igarapé Piri, entre duas aldeias tupinambás, a colônia portuguesa nomeada primeiramente de Feliz Lusitânia, e que se transformaria na cidade de Belém do Pará.

A vinda de escravos negros se deu de forma mais intensa e organizada a partir de meados do século XVIII, com a criação da Companhia Geral de Comércio do Grão Pará e Maranhão, que se encarregou, durante 22 anos, em trazer mais de 13.000 escravos negros para a região norte do Brasil provenientes, fundamentalmente, da costa atlântica da África (Salles 2005).

A formação da população de Belém também foi alvo de estudos genéticos. A origem dos africanos que contribuíram para a formação de Belém foi inferida a partir da caracterização de haplótipos ligados ao alelo $\mathrm{HBB}^{*} \mathrm{~S}$, do gene da cadeia beta da hemoglobina. Esses haplótipos têm uma distribuição geográfica que permite discriminar e quantificar a origem das migrações formadoras de uma população. Assim, Lemos e Guerreiro (2006) caracterizaram estes haplótipos em pacientes com anemia falciforme em Belém e os resultados sugerem uma maior contribuição da etnia Bantu (66\%), cuja distribuição geográfica na África corresponde a países como Angola, Congo e Moçambique. Adicionalmente, linhagens Benin (21,8\%) e Senegal $(10,9 \%)$ 
também puderam ser identificadas, sugerindo que países como Nigéria, Togo e Senegal também contribuíram na formação da população de Belém.

Estudos posteriores usando mtDNA e marcadores do cromossomo Y mostraram que as regiões centro-oeste e sudeste da África constituem a principal origem dos escravos trazidos para o Brasil (Hünemeier et al., 2007).

Uma abordagem similar pode ser feita para se identificar quais grupos indígenas teriam contribuído mais para a formação étnica de Belém. Usando os haplogrupos de DNA mitocondrial específicos de populações indígenas (A, B, C e D), pode-se comparar as frequências destes haplogrupos em Belém com as de diversos grupos indígenas Santos et al. (1999) verificaram que os haplogrupos B e C foram os mais frequentes na população de Belém. Esses dados, quando comparados com os de várias tribos indígenas do Estado do Pará (Silva et al. 2001) sugerem que tribos do grupo linguístico Gê, representado pelos Kayapós, podem ter sido uma importante fonte de contribuição indígena em Belém, visto que o haplogrupo B é o mais frequente neste grupo linguístico (62\%).

Adicionalmente o grupo linguístico Karib, representado por tribos como Arara, Katuena e Wayana-Apalai, apresenta o haplogrupo C como o mais frequente, sendo uma segunda importante fonte de genes indígenas para a formação de Belém. A contribuição de grupos Tupi para a formação de Belém, historicamente associada à formação da população de Belém, não pode ser descartada, pois algumas tribos como Assurini e Awá-Guajá possuem elevada frequência do haplogrupo B.

Esse panorama nos permite estabelecer as contribuições de populações parentais para a população de Belém, onde europeus portugueses, africanos da etnia Bantu e 
ameríndios dos grupos linguísticos Gê, Karib e Tupi tiveram uma contribuição importante para a formação dessa população do Norte do Brasil.

\section{3- Justificativa}

No presente estudo utilizamos a abordagem de mapeamento por miscigenação para testar a hipótese de que há seleção recente atuando nos genes do MHC. Diferente dos estudos anteriores em outras populações (ex., Tang et al., 2007, Johnson et al., 2011), nós não empreendemos um método de varredura genômica, mas utilizamos um painel de STR espalhados pelo genoma para estimar a ancestralidade dos indivíduos, e um conjunto de microssatélites na região do MHC para estimar a ancestralidade nessa região específica. A comparação entre essas medidas de ancestralidade constitui o nosso teste para a ação da seleção recente na região do MHC.

No presente estudo a nossa população miscigenada escolhida foi a da cidade de Belém do Pará. Nossa amostra é constituída por indivíduos de origem tri-híbrida com ancestralidade europeia, africana e ameríndia.

A população da cidade de Belém apresenta um alto índice de ancestralidade ameríndia (Santos et al., 2010), em relação à média de outras grandes cidades brasileiras, e dessa forma, constitui uma amostra ideal para fazer uma análise comparativa dos três principais componentes de ancestralidade. A comparação dos efeitos da seleção natural sobre os perfis de miscigenação em diferentes populações miscigenadas das Américas permitirá inferências sobre como os regimes de seleção natural variam numa escala geográfica intra-continental, e como as diferentes combinações de cenários demográficos, associados a diferentes populações miscigenadas, interage com os regimes seletivos aos quais elas estão sujeitas. 


\section{2- Objetivos}

\section{1- Geral}

Neste estudo realizamos a genotipagem de um conjunto de STR genômicos (não ligados entre si e espalhados pelo genoma), e de outro conjunto localizado na região do MHC. Estimamos proporções de ancestralidade para essas duas regiões genômicas, com o objetivo de testar a hipótese de que há diferenças entre elas, compatíveis com diferenças nas pressões seletivas às quais cada uma está exposta.

\section{2- Específicos}

Para realizar o teste de comparação de ancestralidade definimos os seguintes objetivos:

a- Estimar a variabilidade genética de 10 STR localizados na região do MHC e de 54 STR espalhados pelo restante do genoma, em uma amostra da população da Cidade de Belém, e para amostras de populações parentais: europeia- portuguesa, africana-angolana e ameríndia-amazônica;

b- Estimar a contribuição de ancestralidade europeia, africana e ameríndia na amostra populacional de Belém, tanto para a região do MHC quanto para o restante do genoma;

c- Testar, a partir da comparação entre as estimativas de ancestralidade e diferenciação populacional, se há desvio na contribuição dos componentes ancestrais para a região do MHC em relação ao resto do genoma. 


\section{3- Material e Métodos}

\section{1- Amostras}

\subsection{1- Amostras miscigenadas}

Como população miscigenada, utilizamos uma amostra de 202 indivíduos da população urbana da cidade de Belém, Pará, Brasil. As amostras fazem parte do banco de DNA controle do Laboratório de Genética Humana e Médica (LGHM), da Universidade Federal do Pará (UFPA). O DNA foi extraído a partir de $2 \mathrm{ml}$ de sangue total. Estas amostras são um subconjunto das que foram utilizadas em um estudo de associação de KIR com Artrite Reumatóide e Lúpus Eritematoso Sistêmico (Pedroza et al., 2011), e foram gentilmente cedidas pelo Prof. Dr. Eduardo José Melo dos Santos.

Os indivíduos da amostra tem idade média de 37 anos, são naturais de Belém, não aparentados e saudáveis. Esta amostra mostrou-se representativa da população, pois foi posteriormente usada em outros estudos do tipo caso-controle e suas estimativas de ancestralidade foram muito similares à de amostras de pacientes (coletados tanto da rede pública, como da rede privada de saúde) com Lúpus Eritematoso Sistêmico (Pedroza et al., 2011), Artrite Reumatóide (Sauma, 2010), infectados pelo vírus da Hepatite C (Vasconcelos et al., 2013) e HTLV-1 (Tamegão-Lopes, 2011).

Sendo assim, esta homogeneidade indica que não houve viés socioeconômico na seleção de amostras, um controle importante uma vez que, infelizmente no Brasil, esse fator ainda está fortemente correlacionado ao componente ancestral.

\subsection{2- Amostras Parentais.}


Para a análise das proporções de ancestralidade na população de Belém, foram utilizados 22 indivíduos europeu oriundos de Portugal, 18 de indivíduos africanos naturais da Angola, pertencentes ao grupo étnico dos Ovibundus, de origem Bantu, e 124 amostras de ameríndios amazônicos dos grupos linguísticos Gê, Karib e Tupi (Tabela 12).

As amostras europeias e africanas tiveram seu DNA extraído a partir de amostras de saliva no Instituto de Patologia Molecular e Imunologia da Universidade do Porto (IPATIMUP), Portugal, em estudo sob a coordenação do Prof. Dr. Jorge Rocha, do Centro de Investigação em Biodiversidade e Recursos Genéticos (CIBIO) na cidade do Porto, em Portugal.

As amostras ameríndias foram coletadas e o DNA foi extraído por pesquisadores do LGHM da UFPA e gentilmente cedido pelo Prof. Dr. Eduardo José Melo dos Santos.

Todos os indivíduos pertencentes às populações parentais, incluindo os ameríndios, já haviam sido genotipados para microssatélites genômicos e do MHC previamente (Nunes, 2011) e os dados foram cedidos por Kelly Nunes, integrante do nosso grupo de pesquisa. A metodologia de genotipagem descrita a seguir foi implementada apenas para a amostra de Belém.

Como já foi dito na introdução, a escolha das populações parentais para esse estudo foi embasada em relatos históricos que apontam uma contribuição majoritariamente portuguesa, no que se refere à ancestralidade europeia, e angolana no que diz respeito à ancestralidade africana.

O conhecimento da contribuição ameríndia para a formação da população de Belém ainda é limitado (Salles e Vicente, 2005; Simonian, 2010). Portanto, usamos um critério genético para a incorporação de população em um grupo parental ameríndio. 
Tabela 12. Descrição das amostras utilizadas no presente estudo e tamanho amostral.

\begin{tabular}{lc}
\hline Populações & $\begin{array}{c}\text { Tamanho Amostral } \\
\text { (n) }\end{array}$ \\
\hline Belém & 202 \\
Africanos Angolanos & 18 \\
Europeus Portugueses & 22 \\
Ameríndias & \\
Tiriyó & 10 \\
Arara do Laranjal & 16 \\
Urubu Ka'apor & 20 \\
Awá- Guajá & 11 \\
Parakanã & 9 \\
Assurini & 20 \\
Kayapó Krokaimoro & 18 \\
Kayapó Xikrin & 20 \\
\hline Total & 364 \\
\hline
\end{tabular}

Essa escolha foi feita com base nos resultados obtidos por Nunes (2011), onde se observou que as populações da região denominada de "Leste da América do Sul", constituída por populações do leste da Amazônia e Centro-Sul do Brasil, formam um agrupamento geneticamente diferenciado do restante das populações nativas da América do Sul. Em nossa avaliação, essas populações possuem uma maior probabilidade de serem descendentes dos ameríndios que contribuíram para a formação da população de Belém, e, portanto, foram usadas como parentais da população miscigenada.

\section{2- Marcadores Microssatélite}

\subsection{1- STR (Short Tandem Repeats)}

As amostras da população de Belém foram genotipadas para: (a) 67 STR tetranucleotídeos localizados em diversas regiões do genoma, que serão citados ao longo desse capítulo como "STR Genômicos" (Tabela 13); e (b) 10 STR (sendo oito 
dinucleotídeos e dois tetranucleotídeos), localizados na região do MHC (Tabela 14 e Figura 14), e que serão chamados de "STR do MHC".

As genotipagens foram realizadas durante o estágio de doutorado no exterior (Processo CAPES BEX - 0318-11-6) no Centro de Testagem Molecular (CTM) do Centro de Investigação em Biodiversidade e Recursos Genéticos (CIBIO), na Universidade do Porto, Portugal, sob a supervisão do Prof. Dr. Jorge Rocha.

Os STR genômicos estão divididos em dois grupos: 32 foram padronizados por Nunes (2011) (STR-USP) e 45 que foram padronizados pelo grupo do Prof. Jorge Macedo Rocha (STR-UP) (Tabela 13). Como ambos os conjuntos de STR foram escolhidos independentemente, a partir do banco de dados de 678 STR genotipados no trabalho de WANG et al., 2007, há sete STR que se sobrepõem nos dois grupos, e que portanto foram genotipados duas vezes, oferecendo um controle para calibração de erro de genotipagem.

Tabela 13: Lista dos 67 STR genômicos usados no projeto, com informações sobre a localização no genoma, nome do lócus, nome e tipo do marcador.

\begin{tabular}{cllc}
\hline Cromossomo & Lócus & Marcador & Tipo de marcador \\
\hline 1 & $D 1 S 551$ & GATA6A05 & USP/UP \\
1 & $N A-D 1 S-3$ & GATA133A08Q & UP \\
1 & $D 1 S 1660$ & GATA48B01 & USP \\
1 & $D 1 S 1665$ & GATA61A06 & UP \\
2 & GATA148G10P_2 & GATA148G10P & UP \\
2 & $D 2 S 1328$ & GATA27A12 & UP \\
2 & $D 2 S 1391$ & GATA65C03M & UP \\
2 & $D 2 S 2968$ & GATA178G09M & UP \\
3 & $D 3 S 3038$ & GATA73D01 & USP \\
3 & GATA146B10_3 & GATA146B10 & UP \\
3 & $D 3 S 3039$ & GATA7F05 & USP \\
3 & $D 3 S 1763$ & GATA3H01 & USP \\
4 & $D 4 S 2366$ & GATA22G05M & USP \\
4 & $D 4 S 3248$ & GATA28F03 & USP/UP \\
4 & $D 4 S 2368$ & GATA27G03 & USP \\
4 & $D 4 S 1652$ & GATA5B02M & UP \\
5 & $D 5 S 2500$ & GATA67D03 & USP \\
5 & $D 5 S 816$ & GATA2H09 & USP
\end{tabular}




$\begin{array}{lllc}5 & \text { D5S1456 } & \text { GATA11A11P } & \text { USP } \\ 6 & \text { GATA112F02P_6 } & \text { GATA112F02P } & \text { UP } \\ 6 & \text { D6S474 } & \text { GATA31 } & \text { UP } \\ 6 & \text { D6S1040 } & \text { GATA23F08 } & \text { USP/UP } \\ 6 & D 6 S 1277 & \text { GATA81B01 } & \text { UP } \\ 7 & D 7 S 3056 & \text { GATA24F03ZP } & \text { UP }\end{array}$

Tabela 13 continuação: Lista dos 67 STR genômicos usados no projeto, com informações sobre a localização no genoma, nome do lócus, nome e tipo do marcador.

\begin{tabular}{cllc}
\hline Cromossomo & Lócus & Marcador & Tipo de marcador \\
\hline 7 & $D 7 S 3047$ & GATA119B03 & UP \\
7 & $D 7 S 2846$ & GATA31A10 & USP \\
7 & $D 7 S 821$ & GATA5D08 & USP \\
7 & $D 7 S 3061$ & GGAA6D03N & USP \\
7 & TATG002P_7 & TATG002P & UP \\
8 & $D 8 S 1136$ & GATA41A01 & UP \\
8 & $D 8 S 2324$ & GATA14E09 & USP \\
8 & $D 8 S 1128$ & GATA21C12 & UP \\
9 & $D 9 S 1121$ & GATA87E02N & UP \\
9 & $D 9 S 1122$ & GATA89A11 & UP \\
9 & $D 9 S 301$ & GATA7D12 & USP \\
9 & $D 9 S 922$ & GATA21F05 & USP \\
9 & $D 9 S 934$ & GATA64G07 & UP \\
10 & $D 10 S 1435$ & GATA88F09 & UP \\
10 & $D 10 S 1426$ & GATA73E11 & USP \\
10 & $D 10 S 2327$ & GGAT1A4 & USP \\
10 & $D 10 S 2470$ & GATA115E01N & USP \\
10 & $D 10 S 1248$ & GGAA23C05N & UP \\
11 & $D 11 S 2365$ & GATA63F09 & UP \\
11 & $N E W 01$ & GATA71E06 & USP \\
12 & $D 12 S 395$ & GATA4H01 & USP \\
12 & $D 12 S 1300$ & GATA85A04M & USP/UP \\
12 & $D 12 S 373$ & GATA6C01 & UP \\
13 & $D 13 S 894$ & GATA86H01 & UP
\end{tabular}

Tabela 13 continuação: Lista dos 67 STR genômicos usados no projeto, com informações sobre a localização no genoma, nome do lócus, nome e tipo do marcador.

\begin{tabular}{cllc}
\hline Cromossomo & Lócus & Marcador & Tipo de marcador \\
\hline 13 & $D 13 S 1807$ & GATA11C08P & UP \\
13 & $D 13 S 800$ & GATA64F08 & UP \\
13 & $D 13 S 317$ & GATA7G10 & USP/UP \\
14 & $D 14 S 1280$ & GATA31B09 & UP \\
14 & $D 14 S 588$ & GGAA4A12 & USP
\end{tabular}




$\begin{array}{lllc}14 & D 14 S 1434 & \text { GATA168F06 } & \text { UP } \\ 15 & D 15 S 1515 & \text { GATA197B10P } & \text { UP } \\ 16 & \text { D16S3253 } & \text { GATA22F09P } & \text { UP } \\ 16 & \text { D16S539 } & \text { GATA11C06N } & \text { USP } \\ 16 & \text { D16S764 } & \text { GATA42E11 } & \text { UP } \\ 17 & \text { GATA64B04P_17 } & \text { GATA64B04P } & \text { UP } \\ 17 & \text { G17S1299 } & \text { GATA25A04 } & \text { USP } \\ 17 & \text { GATA63G01_17 } & \text { GATA63G01 } & \text { UP } \\ 18 & D 18 S 877 & \text { GATA64H04 } & \text { UP } \\ 18 & \text { D18S535 } & \text { GATA13 } & \text { USP/UP } \\ 19 & \text { D19S559 } & \text { UT7544 } & \text { UP } \\ 20 & D 20 S 482 & \text { GATA51D03 } & \text { USP/UP } \\ 21 & D 21 S 1432 & \text { GATA11C12 } & \text { UP } \\ 21 & \text { GATA163G03_21 } & \text { GATA163G03 } & \text { UP } \\ 21 & D 21 S 1437 & \text { GGAA3C07 } & \text { USP } \\ 22 & D 22 S 689 & \text { GATA21F03 } & \text { UP } \\ \text { UP= Universidade do Porto } ; & \text { USP=Universidade de São Paulo }\end{array}$

Tabela 14: Lista dos 10 STR do MHC utilizados com informações sobre o tipo de unidade de repetição.

\begin{tabular}{lll}
\hline Locus & Marcador & Tipo de repetição \\
\hline$D 6 S 2972$ & $M 0 G 2$ & AC (dinucleotídeo) \\
$D 6 S 265$ & $D 6 S 265$ & CA (dinucleotídeo) \\
$D 6 S 2811$ & $H L A B C-C A$ & CA (dinucleotídeo) \\
$D 6 S 2928$ & $D 6 S 2928$ & TTTG (tetranucleotídeo) \\
$D 6 S 2927$ & $D 6 S 2927$ & TTTG (tetranucleotídeo) \\
$S T R-M I C A$ & $M I C A-C A$ & GCT (dinucleotídeo \\
$D 6 S 2789$ & $T N F-C A$ & imperfeito) \\
$D 6 S 2665$ & $D R A-C A$ & AG (dinucleotídeo) \\
$D 6 S 2876$ & $G 51152$ & AC (dinucleotídeo) \\
$D 6 S 2749$ & RING3 & GT (dinucleotídeo) \\
\hline
\end{tabular}

Um critério fundamental de seleção dos STR do MHC foi a proximidade dos mesmos em relação a genes HLA, que são importantes alvos de seleção (ver introdução geral). A figura 14 ilustra essa proximidade. 


\section{3- Amplificação do genoma inteiro}

Para todas as amostras de Belém, realizamos a amplificação de genoma inteiro com o auxílio do GenomiPhi V2 DNA Amplification Kit (GE Healthcare) seguindo instruções do fabricante.
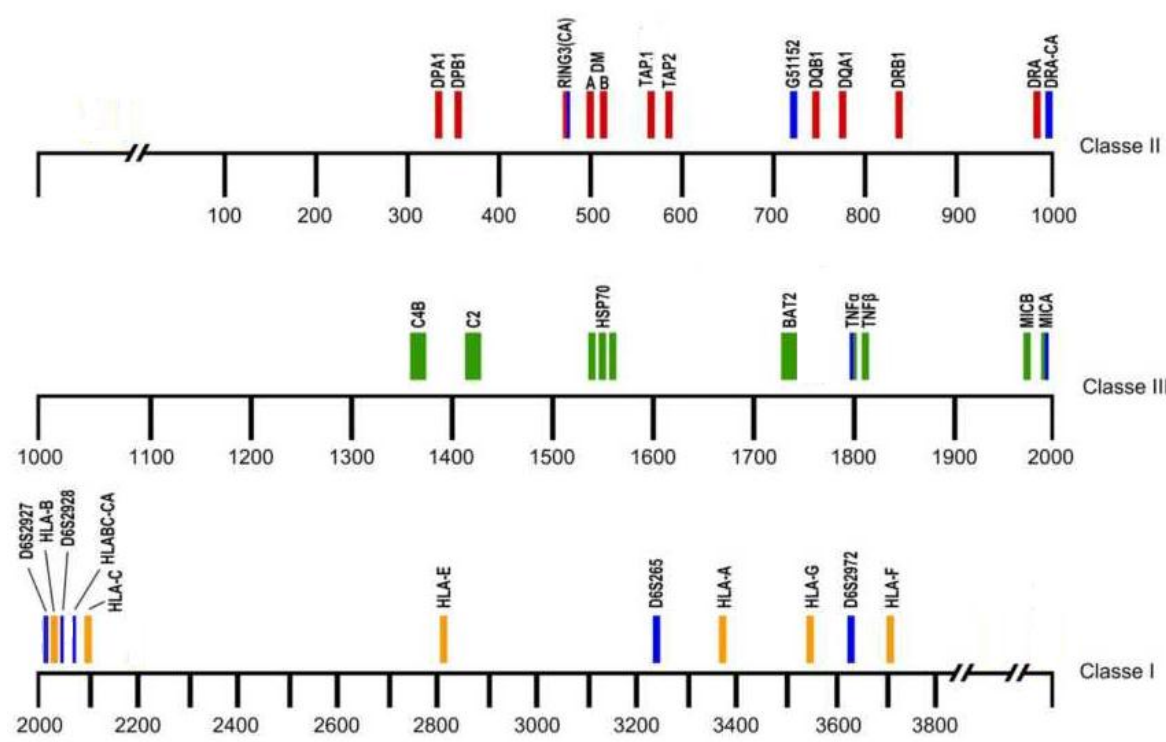

Figura 14: Localização dos STR ao na região do MHC. Em azul, estão representados os STR, em vermelho estão os genes de classe II, em verde os genes de classe III, e em amarelo os genes de classe I.

\section{4- Reação em cadeia da polimerase (PCR)}

As amplificações dos fragmentos de DNA contendo STR foram realizadas através de "multiplexagem" dos oligonucleotídeos iniciadores na reação de PCR (Tabelas 4 e 5 para os STR genômicos e Tabela 6 para STR do MHC).

Todos os STR foram genotipados no CTM, em Portugal. Para a reação de PCR foi utilizado o kit de amplificação Taq PRC Master Mix da Qiagen ®. Os ciclos de amplificação foram: $95^{\circ} \mathrm{C}$ por 15 minutos, 11 ciclos de $95{ }^{\circ} \mathrm{C}$ por 30 segundos, 
touchdown de 61 a $56^{\circ} \mathrm{C}$ por 30 segundos, e $72{ }^{\circ} \mathrm{C}$ por 30 segundos, seguidos de 31 ciclos de $95^{\circ} \mathrm{C}$ por 30 segundos, $56^{\circ} \mathrm{C}$ por 1 minuto e $72^{\circ} \mathrm{C}$ por 39 segundos seguidos de extensão final de $60^{\circ} \mathrm{C}$ por 30 minutos.

As $P C R$ foram realizadas em placas de 96 poços e cada uma possuia dois controles positivos, que eram amostras com reconhecida qualidade na amplificação, e um controle negativo, consistindo do mix de reação de amplificação.

Tabela 15. Reação de genotipagem dos STR: informações sobre conjunto de multiplexagem, e concentração dos oligonucleotídeos iniciadores dos STR-USP multiplexados.

\begin{tabular}{|c|c|c|c|c|c|c|}
\hline \multicolumn{7}{|c|}{ MULTIPLEX 1 - USP } \\
\hline Locus & $\begin{array}{c}\text { Tamanho } \\
\text { (PB) }\end{array}$ & Fluorescência & $\begin{array}{l}{[] \text { ini }} \\
(\mathrm{pmol} / \mu \mathrm{l})\end{array}$ & $\begin{array}{l}\text { Qtde } \\
(\mu \mathrm{l})\end{array}$ & $\begin{array}{l}\text { []final } \\
(\mathbf{p m o l} / \mu \mathrm{l})\end{array}$ & $\begin{array}{l}\text { [] PCR } \\
(\mathrm{pmol} / \mu \mathrm{l})\end{array}$ \\
\hline D5S816 & $122-154$ & FAM & 20 & 4 & 0,8 & 0,08 \\
\hline D1S55 & $167-187$ & FAM & 20 & 4 & 0,8 & 0,08 \\
\hline D7S3061 & $204-240$ & FAM & 20 & 6 & 1,2 & 0,12 \\
\hline D4S3248 & $268-296$ & FAM & 20 & 8 & 1,6 & 0,16 \\
\hline D16S539 & $137-169$ & HEX & 20 & 4 & 0,8 & 0,08 \\
\hline D9S922 & $180-204$ & HEX & 20 & 4 & 0,8 & 0,08 \\
\hline D10S1426 & $221-237$ & $\mathrm{HEX}$ & 20 & 6 & 1,2 & 0,12 \\
\hline D7S821 & $265-297$ & $\mathrm{HEX}$ & 20 & 8 & 1,6 & 0,16 \\
\hline \multicolumn{7}{|c|}{ MULTIPLEX 2 - USP } \\
\hline Locus & $\begin{array}{l}\text { Tamanho } \\
\text { (PB) }\end{array}$ & Fluorescência & $\begin{array}{l}{[] \text { ini }} \\
(\mathbf{p m o l} / \mu \mathrm{l})\end{array}$ & $\begin{array}{l}\text { Qtde } \\
(\mu \mathrm{l})\end{array}$ & $\begin{array}{l}\text { []final } \\
(\mathbf{p m o l} / \mu \mathrm{l})\end{array}$ & $\begin{array}{l}\text { [] PCR } \\
\text { (pmol/ } / \mu \mathrm{l})\end{array}$ \\
\hline D13S317 & $116-156$ & FAM & 20 & 4 & 0,8 & 0,08 \\
\hline D8S2324 & $198-218$ & FAM & 20 & 6 & 1,2 & 0,12 \\
\hline D19S559 & $229-249$ & FAM & 20 & 6 & 1,2 & 0,12 \\
\hline D6S1040 & $285-309$ & FAM & 20 & 8 & 1,6 & 0,16 \\
\hline D20S482 & $106-146$ & HEX & 20 & 6 & 1,2 & 0,12 \\
\hline D9S301 & $197-233$ & HEX & 20 & 4 & 0,8 & 0,08 \\
\hline D18S535 & $242-270$ & HEX & 20 & 6 & 1,2 & 0,12 \\
\hline D21S1437 & $208-244$ & $\mathrm{HEX}$ & 20 & 8 & 1,6 & 0,16 \\
\hline
\end{tabular}


Tabela 15 continuação. Reação de genotipagem dos STR: informações sobre conjunto de multiplexagem, e concentração dos oligonucleotídeos iniciadores dos STR-USP multiplexados.

\begin{tabular}{lcccccc}
\hline \multicolumn{7}{c}{ MULTIPLEX 3-USP } \\
\hline Locus & $\begin{array}{c}\text { Tamanho } \\
(\mathbf{p b})\end{array}$ & Fluorescência & $\begin{array}{l}{[] \text { ini }} \\
(\mathbf{p m o l} / \boldsymbol{\mu l})\end{array}$ & $\begin{array}{l}\text { Qtde } \\
(\boldsymbol{\mu l})\end{array}$ & $\begin{array}{l}{[] f i n a l} \\
(\mathbf{p m o l} / \boldsymbol{\mu l})\end{array}$ & $\begin{array}{l}{[] \text { PCR }} \\
(\mathbf{p m o l} / \boldsymbol{\mu l})\end{array}$ \\
\hline D12S395 & $207-235$ & FAM & 30 & 4 & 1,2 & 0,12 \\
D17S1299 & $248-276$ & FAM & 30 & 4 & 1,2 & 0,12 \\
D1S1660 & $320-348$ & FAM & 30 & 6 & 1,8 & 0,18 \\
D3S3039 & $351-391$ & FAM & 30 & 6 & 1,8 & 0,18 \\
D10S2470 & $220-248$ & HEX & 30 & 4 & 1,2 & 0,12 \\
D4S2366 & $326-350$ & HEX & 30 & 4 & 1,2 & 0,12 \\
New & $355-379$ & HEX & 30 & 6 & 1,8 & 0,18 \\
D3S3038 & $380-416$ & HEX & 30 & 8 & 2,4 & 0,24 \\
\hline
\end{tabular}

Tabela 16. Reação de genotipagem dos STR: informações sobre conjunto de multiplexagem, e concentração dos oligonucleotídeos dos STR-UP multiplexados.

\begin{tabular}{|c|c|c|c|c|c|c|}
\hline \multicolumn{7}{|c|}{ MULTIPLEX 1-UP } \\
\hline Locus & $\begin{array}{c}\text { Tamanho } \\
\text { (PB) }\end{array}$ & Fluorescência & 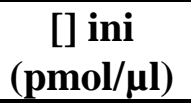 & $\begin{array}{c}\text { Qtde } \\
(\mu \mathrm{l})\end{array}$ & $\begin{array}{c}\text { []final } \\
(\mathrm{pmol} / \mu \mathrm{l})\end{array}$ & $\begin{array}{c}{[] \mathrm{pcr}} \\
(\mathrm{pmol} / \mu \mathrm{l})\end{array}$ \\
\hline D18S877 & $109-141$ & VIC & 100 & 2,4 & 2,4 & 0,24 \\
\hline D10S1248 & $221-269$ & FAM & 100 & 4,4 & 4,4 & 0,44 \\
\hline D10S1435 & $244-288$ & PET & 100 & 8 & 8 & 0,8 \\
\hline D11S2365 & $226-258$ & VIC & 100 & 2 & 2 & 0,2 \\
\hline D13S1807 & $182-214$ & PET & 100 & 1,6 & 1,6 & 0,16 \\
\hline D16S3253 & $163-203$ & VIC & 100 & 2,8 & 2,8 & 0,28 \\
\hline D16S764 & $92-124$ & FAM & 100 & 1,6 & 1,6 & 0,16 \\
\hline D1S551 & $158-190$ & FAM & 100 & 3,2 & 3,2 & 0,32 \\
\hline D2S2968 & $167-167$ & NED & 100 & 1,2 & 1,2 & 0,12 \\
\hline D8S1136 & $229-269$ & NED & 100 & 10 & 10 & 1 \\
\hline \multicolumn{7}{|c|}{ MULTIPLEX 2_UP } \\
\hline Locus & $\begin{array}{c}\text { Tamanho } \\
(\mathbf{P B})\end{array}$ & Fluorescência & $\begin{array}{c}{[] \text { ini }} \\
(\mathrm{pmol} / \mu \mathrm{l})\end{array}$ & $\begin{array}{l}\text { Qtde } \\
(\mu \mathrm{l})\end{array}$ & $\begin{array}{c}\text { []final } \\
(\mathrm{pmol} / \mu \mathrm{l})\end{array}$ & $\begin{array}{c}{[] \mathrm{pcr}} \\
(\mathrm{pmol} / \mu \mathrm{l})\end{array}$ \\
\hline D2S1328 & $138-170$ & VIC & 100 & 1,6 & 1,6 & 0,16 \\
\hline D6S474 & $139-179$ & FAM & 100 & 1,6 & 1,6 & 0,16 \\
\hline D20S482 & 139-171 & NED & 100 & 0,9 & 0,9 & 0,09 \\
\hline D7S3047 & $156-188$ & PET & 100 & 5,6 & 5,6 & 0,56 \\
\hline D22S689 & $194-234$ & VIC & 100 & 1,6 & 1,6 & 0,16 \\
\hline D1S1665 & $211-255$ & FAM & 100 & 2,8 & 2,8 & 0,28 \\
\hline D15S1515 & $196-224$ & NED & 100 & 1,4 & 1,4 & 0,14 \\
\hline D14S1434 & $208-236$ & PET & 100 & 1,6 & 1,6 & 0,16 \\
\hline D6S1277 & $278-318$ & VIC & 100 & 4 & 4 & 0,4 \\
\hline D14S1280 & $277-312$ & FAM & 100 & 2,4 & 2,4 & 0,24 \\
\hline
\end{tabular}

Tabela 16 continuação. Reação de genotipagem dos STR: informações sobre 
conjunto de multiplexagem, e concentração dos oligonucleotídeos dos STR-UP multiplexados.

\begin{tabular}{|c|c|c|c|c|c|c|}
\hline \multicolumn{7}{|c|}{ MULTIPLEX 3_UP } \\
\hline Locus & $\begin{array}{c}\text { Tamanho } \\
\text { (PB) }\end{array}$ & Fluorescência & $\begin{array}{c}{[] \text { ini }} \\
(\mathrm{pmol} / \mu \mathrm{l})\end{array}$ & $\begin{array}{c}\text { Qtde } \\
(\mu \mathrm{l})\end{array}$ & $\begin{array}{c}{[] f i n a l} \\
(\mathrm{pmol} / \mu \mathrm{l})\end{array}$ & $\begin{array}{c}{[] \mathrm{pcr}} \\
(\mathrm{pmol} / \mu \mathrm{l})\end{array}$ \\
\hline D4S1652 & $126-154$ & VIC & 100 & 2,4 & 2,4 & 0,24 \\
\hline D12S1300 & $111-143$ & FAM & 100 & 2,4 & 2,4 & 0,24 \\
\hline D9S1122 & $186-214$ & NED & 100 & 5,6 & 5,6 & 0,56 \\
\hline D9S1121 & $172-228$ & PET & 100 & 1,6 & 1,6 & 0,16 \\
\hline D13S894 & $176-212$ & VIC & 100 & 1,6 & 1,6 & 0,16 \\
\hline D7S3056 & $164-192$ & FAM & 100 & 1,6 & 1,6 & 0,16 \\
\hline D6S1040 & $257-289$ & NED & 100 & 2,8 & 2,8 & 0,28 \\
\hline D8S1128 & $240-268$ & PET & 100 & 8 & 8 & 0,8 \\
\hline D21S2053 & $255-263$ & VIC & 100 & 1,6 & 1,6 & 0,16 \\
\hline D4S3248 & $229-265$ & FAM & 100 & 2 & 2 & 0,2 \\
\hline \multicolumn{7}{|c|}{ MULTIPLEX 4_UP } \\
\hline Locus & $\begin{array}{c}\text { Tamanho } \\
\text { (PB) }\end{array}$ & Fluorescência & $\begin{array}{c}{[] \text { ini }} \\
(\mathrm{pmol} / \mu \mathrm{l})\end{array}$ & $\begin{array}{c}\text { Qtde } \\
(\mu \mathrm{l})\end{array}$ & $\begin{array}{c}{[] f i n a l} \\
(\mathrm{pmol} / \mu \mathrm{l})\end{array}$ & $\begin{array}{c}{[] \mathrm{pcr}} \\
(\mathrm{pmol} / \mu \mathrm{l})\end{array}$ \\
\hline G15727 & $102-167$ & VIC & 100 & 2,4 & 2,4 & 0,24 \\
\hline D6S1270 & $112-144$ & FAM & 100 & 2,4 & 2,4 & 0,24 \\
\hline D2S1391 & $102-154$ & NED & 100 & 32 & 32 & 3,2 \\
\hline GATA146B10 & $147-207$ & PET & 100 & 1,6 & 1,6 & 0,16 \\
\hline D17S1534 & $206-250$ & VIC & 100 & 1,2 & 1,2 & 0,12 \\
\hline D13S317 & $167-207$ & FAM & 100 & 8 & 8 & 0,8 \\
\hline D12S373 & $192-232$ & NED & 100 & 1,2 & 1,2 & 0,12 \\
\hline GATA146B10 & $230-270$ & PET & 100 & 8 & 8 & 0,8 \\
\hline D13S800 & $283-331$ & VIC & 100 & 3,2 & 3,2 & 0,32 \\
\hline D17S1303 & $232-252$ & FAM & 100 & 1,6 & 1,6 & 0,16 \\
\hline
\end{tabular}

Tabela 16 continuação. Reação de genotipagem dos STR: informações sobre conjunto de multiplexagem, e concentração dos oligonucleotídeos dos STR-UP multiplexados.

\begin{tabular}{|c|c|c|c|c|c|c|}
\hline \multicolumn{7}{|c|}{ MULTIPLEX 5 - UP } \\
\hline Locus & $\begin{array}{c}\text { Tamanho } \\
\text { (PB) }\end{array}$ & Fluorescência & $\begin{array}{c}{[] \mathrm{ini}} \\
(\mathrm{pmol} / \mu \mathrm{l})\end{array}$ & $\begin{array}{c}\text { Qtde } \\
(\mu \mathrm{l})\end{array}$ & $\begin{array}{c}\text { []final } \\
(\mathrm{pmol} / \mu \mathrm{l})\end{array}$ & $\begin{array}{c}{[] \mathrm{pcr}} \\
(\mathrm{pmol} / \mu \mathrm{l})\end{array}$ \\
\hline TATG002P & $147-187$ & FAM & 100 & 1,2 & 1,2 & 0,12 \\
\hline D18S535 & $123-167$ & NED & 100 & 1,2 & 1,2 & 0,12 \\
\hline D9S934 & $198-242$ & FAM & 100 & 1,2 & 1,2 & 0,12 \\
\hline GATA146B10 & $230-270$ & PET & 100 & 16 & 16 & 1,6 \\
\hline D17S1534 & $206-250$ & VIC & 100 & 16 & 16 & 1,6 \\
\hline
\end{tabular}


Tabela 17. Informação sobre os STR do MHC, reação de PCR (Temperatura de hibridação - TA; concentração dos oligonucleotídeos iniciadores - oligos e concentração do cloreto de magnésio - $\mathrm{MgCl}$ ) e os agrupamentos para eletroforese.

\begin{tabular}{ccccccc}
\hline Marcador & Tamanho $(\mathbf{p b})$ & Fluorescência & TA $\left({ }^{\circ} \mathbf{C}\right)$ & $\begin{array}{c}\text { [] de } \\
\text { Oligos } \\
(\mathbf{p m o l})\end{array}$ & MgCl2 $(\mathbf{m M})$ & $\begin{array}{c}\text { Agrupamento } \\
\text { na } \\
\text { Eletroforese }\end{array}$ \\
\hline $\boldsymbol{H L A} \boldsymbol{- B C}$ & $90-120$ & VIC & 57 & 0,3 & 3,34 & $\mathrm{~A}$ \\
$\boldsymbol{G 5 1 1 5 2}$ & $192-236$ & NED & 57 & 0,3 & 3,34 & $\mathrm{~A}$ \\
$\boldsymbol{D R} \boldsymbol{A}-\boldsymbol{C A}$ & $240-270$ & NED & 57 & 0,75 & 3,34 & $\mathrm{~A}$ \\
$\boldsymbol{M I C A}$ & $180-200$ & VIC & 55 & 0,75 & 3,34 & $\mathrm{~B}$ \\
$\boldsymbol{D 6 S 2 9 2 7}$ & $228-248$ & FAM & 55 & 0,5 & 3 & $\mathrm{~B}$ \\
$\boldsymbol{D 6 S 2 9 2 8}$ & $253-273$ & VIC & 55 & 0,5 & 3 & $\mathrm{~B}$ \\
$\boldsymbol{R} \boldsymbol{I N G 3}$ & $225-237$ & FAM & 60 & 1,5 & 2,5 & $\mathrm{C}$ \\
$\boldsymbol{T N F}$ & $124-134$ & NED & 60 & 0,8 & 2,5 & $\mathrm{C}$ \\
$\boldsymbol{D 6 S 2 6 5}$ & $176-218$ & VIC & 55 & 0,75 & 3 & $\mathrm{D}$ \\
$\boldsymbol{D 6 S 2 9 7 2}$ & $122-160$ & NED & 55 & 1,5 & 2,5 & $\mathrm{D}$ \\
\hline
\end{tabular}

O PCRs foram visualizados em gel de agarose $2 \%$, corado com o GelRed ${ }^{T M}$ (Invitrogen), para confirmação da amplificação e posterior preparação do produto da reação para a eletroforese de detecção de fragmentos.

\section{5-Genotipagem dos STR - Eletroforese de fragmentos}

As reações de PCR que amplificaram foram preparadas para a eletroforese de genotipagem com 5 a $10 \mu \mathrm{l}$ de produto PCR adicionados a $0,5 \mu 1$ de marcador de peso molecular (GeneScan ${ }^{\mathrm{TM}}$ - 500 ROX ${ }^{\mathrm{TM}}$ Applied Biosystems) e $9 \mu 1$ de formamida (HI$D I^{\mathrm{TM}}$ formamide - Apllied Biosystems). A solução era desnaturada a $95^{\circ} \mathrm{C}$ por 3 minutos e resfriada em placas de gelo.

A eletroforese de separação dos fragmentos que identificam os alelos de STR foi feita no ABI3130 Genetic Analyzer (Applied Biosystems) do CTM.

Confirmações de resultado e repetições necessárias foram feitas no Laboratório 
de Biologia Evolutiva e Conservação de Vertebrados (LABEC), na Universidade de São Paulo, coordenado pelo Prof. Dr. João Stenghel Morgante. Os produtos de amplificação eram encaminhados para Centro de Estudo do Genoma Humano, na USP, para eletroforese de fragmentos.

Os cromatogramas gerados pelo analisador de sequências $A B I$, com os picos correspondentes aos fragmentos de STR, foram analisados com o auxílio do programa Gene Mapper® Software v.4.1 (Applied Biosystem). Para resultados gerados no Centro de Estudos do Genoma Humano, as análises foram feitas pelo programa GeneMarker (SoftGenetics).

\section{6- Definição da base de dados}

Para minimizar o erro experimental, utilizamos os mesmos critérios de exclusão de loci e indivíduos adotados por Nunes (2011), a saber:

1) indivíduos com menos de $50 \%$ dos genótipos;

2) loci com menos de 50\% dos genótipos;

3) loci com falha total de amplificação em alguma população;

4) loci com unidades de repetição imperfeita;

5) loci ausentes do banco de dados de WANG et al. (2007).

Desse processo de depuração restaram 54 STR genômicos e sete STR do MHC (Tabela 18). 
Tabela 18. STR utilizados nas análises após a depuração dos dados.

\begin{tabular}{|c|c|c|}
\hline \multicolumn{3}{|c|}{ STR Genômicos } \\
\hline Cromossomo & Locus & Marcador \\
\hline 1 & D1S551 & GATA6A05 \\
\hline 1 & $N A-D 1 S-3$ & GATA133A08Q \\
\hline 1 & $D 1 S 1660$ & GATA48B01 \\
\hline 2 & GATA148G10P_2 & GATA148G10P \\
\hline 2 & $D 2 S 1328$ & GATA27A12 \\
\hline 2 & D2S1391 & GATA65C03M \\
\hline 2 & $D 2 S 2968$ & GATA178G09M \\
\hline 3 & GATA146B10_3 & GATA146B10 \\
\hline 3 & D3S3039 & GATA7F05 \\
\hline 3 & D3S1763 & GATA3H01 \\
\hline 4 & D4S2366 & GATA22G05M \\
\hline 4 & $D 4 S 3248$ & GATA28F03 \\
\hline 4 & $D 4 S 2368$ & GATA27G03 \\
\hline 5 & D5S2500 & GATA67D03 \\
\hline 5 & D5S816 & GATA2H09 \\
\hline 6 & GATA112F02P_6 & GATA112F02P \\
\hline 6 & $D 6 S 474$ & GATA31 \\
\hline 6 & D6S1040 & GATA23F08 \\
\hline 7 & D7S3047 & GATA119B03 \\
\hline 7 & $D 7 S 2846$ & GATA31A10 \\
\hline 7 & $D 7 S 821$ & GATA5D08 \\
\hline 7 & D7S3061 & GGAA6D03N \\
\hline 7 & TATG002P_7 & TATG002P \\
\hline 8 & D8S1136 & GATA41A01 \\
\hline 8 & D8S2324 & GATA14E09 \\
\hline 8 & $D 8 S 1128$ & GATA21C12 \\
\hline 9 & D9S1121 & GATA87E02N \\
\hline 9 & D9S1122 & GATA89A11 \\
\hline 9 & D9S301 & GATA7D12 \\
\hline 9 & D9S922 & GATA21F05 \\
\hline 9 & D9S934 & GATA64G07 \\
\hline 10 & D10S1435 & GATA88F09 \\
\hline 10 & D10S1426 & GATA73E11 \\
\hline
\end{tabular}


Tabela 18 continuação. STR utilizados nas análises após a depuração dos dados.

\begin{tabular}{|c|c|c|}
\hline$R$ Genômicos & & \\
\hline 10 & D10S2327 & GGAT1A4 \\
\hline 10 & D10S2470 & GATA115E01N \\
\hline 10 & D10S1248 & GGAA23C05N \\
\hline 11 & D11S2365 & GATA63F09 \\
\hline 12 & D12S395 & GATA4H01 \\
\hline 12 & $D 12 S 373$ & GATA6C01 \\
\hline 13 & D13S894 & GATA86H01 \\
\hline 13 & D13S1807 & GATA11C08P \\
\hline 13 & $D 13 S 800$ & GATA64F08 \\
\hline 13 & $D 13 S 317$ & GATA7G10 \\
\hline 14 & D14S1434 & GATA168F06 \\
\hline 15 & $D 15 S 1515$ & GATA197B10P \\
\hline 16 & D16S3253 & GATA22F09P \\
\hline 16 & D16S539 & GATA11C06N \\
\hline 17 & GATA64B04P_17 & GATA64B04P \\
\hline 17 & $D 17 S 1299$ & GATA25A04 \\
\hline 17 & GATA63G01_17 & GATA63G01 \\
\hline 18 & $D 18 S 877$ & GATA64H04 \\
\hline 18 & D18S535 & GATA13 \\
\hline 19 & D19S559 & UT7544 \\
\hline 20 & D20S482 & GATA51D03 \\
\hline 22 & D22S689 & GATA21F03 \\
\hline \multicolumn{3}{|l|}{ STR do MHC } \\
\hline Cromossomo & Locus & Marcador \\
\hline 6 & D6S2972 & M0G2 \\
\hline 6 & D6S265 & D6S265 \\
\hline 6 & D6S2811 & HLABC-CA \\
\hline 6 & D6S2928 & D6S2928 \\
\hline 6 & D6S2927 & D6S2927 \\
\hline 6 & STR-MICA & MICA-CA \\
\hline 6 & D6S2876 & G51152 \\
\hline
\end{tabular}




\section{7-Análise dos dados}

\subsection{1- Frequências alélicas}

As frequências alélicas foram calculadas por contagem direta.

\subsection{2- Desvios do Equilíbrio de Hardy-Weinberg}

Testamos para desvios do equilíbrio de Hardy-Weinberg usando o método de Guo e Thompson (1992) implementado pelo pacote de programas Arlequin 3.5 (Excoffier 2006). Usamos desvios de Hardy-Weinberg como um controle de qualidade para a genotipagem, permitindo a detecção de possíveis alelos nulos, detectáveis pelo excesso de homozigotos. Após todas as analises, aplicamos o método de Bonferroni para correção dos valores de $\mathrm{p}$.

\subsection{3- Descrição da variabilidade genética}

Os seguintes índices de diversidade genética foram estimados: taxa de heterozigose esperada $(\mathrm{He})$, número de alelos $(\mathrm{k})$ e $\theta \mathrm{H}$. Todos valores foram estimados usando o pacote de programas Arlequin 3.5 (Excoffier et al., 2006).

$\mathrm{O} \theta \mathrm{H}$ é um estimador de $\theta(4 \mathrm{~N} \mu)$ obtido a partir da taxa de heterozigose observada, e, no caso de STR, assume-se o modelo de mutação escalonada.

\subsection{4- Estimativa de ancestralidade}

As proporções de ancestralidade individuais e médias para a amostra populacional de Belém foram estimadas com o método de agrupamento Bayesiano 
desenvolvido por (Pritchard, Stephens, \& Donnelly, 2000) implementado no programa STRUCTURE, versão 2.3.4.

Para estimarmos o grau de miscigenação da população de Belém, assumimos desconhecer a origem populacional dos indivíduos miscigenados. O contrário dos indivíduos usados nas amostras parentais, cuja informação populacional é fundamental para que o programa estime a probabilidade de cada indivíduo de origem "desconhecida" ter recebido contribuições genéticas dos grupos pré-estabelecidos (POPFLAG=1 para populações parentais e POPFLAG $=0$ para a amostra miscigenada).

Assumimos a probabilidade de $1 \%$ de haver, na população miscigenada, indivíduos com ancestralidade em outro grupo, na geração atual até 16 gerações anteriores (período que corresponde ao início do processo de formação da população trihibrida de Belém). Os parâmetros usados no STRUCTURE foram: Model $=$ Use population information to test for migrant; GENSBACK=16; MIGRPRIOR=0,01.

O parâmetro alpha, usado na estimativa de proporção de ancestralidade individual, foi inferido para cada população parental (INFERALPHA $\geq 1$ ), o que é mais adequado em um cenário de contribuição genética desigual das populações parentais na população de Belém.

Cada corrida foi realizada utilizando uma Cadeia de Markov com burn-in de 20.000 seguida por 10.000 interações.

3.7.5- Validação dos STR Genômicos como estimadores de ancestralidades. 
Os STR usados nesse estudo não foram escolhidos a priori pela sua capacidade de estimar a ancestralidade em populações miscigenadas. Portanto, para que pudessemos testar a eficácia desses marcadores na execução dessa função utilizamos as estimativas de ancestralidades obtidas por Pedroza et al. (2011) para os mesmos indivíduos por nós utilizados e que foram gentilmente cedidos pelos autores do referido estudo.

Essas estimativas foram obtidas pelo painel de AIM (sigla em inglês para o termo Ancestry Informative Markers) do tipo INDEL (sigla que designa mutações de ponto do tipo INserção e DELeção) desenvolvido por Santos et al. (2010).

O teste consistiu na análise da significância da Correlação de Spearman entre os valores de ancestralidades individuais obtidos para cada uma das três ancestralidades (africana, europeia e ameríndia) por STR Genômicos e INDEL. Os testes foram executados no BioEdit 5.0.

\subsection{6- Diferenciação populacional}

O índice de diferenciação populacional, $F_{S T}$, foi estimado pela função $p p$. $f$ st do pacote HIERFSTAT para R (Goudet, 2007), que implementa o calculo dessa estimativa baseado nos componentes de variância. As significâncias para as estimativas foram obtidas realizando 10.000 permutações de indivíduos os entre populações.

O objetivo de usar o $F_{S T}$ neste estudo é ter uma fonte adicional de informação sobre a diferenciação genética entre as populações, para as duas diferentes regiões do genoma. A nossa premissa é a de que a diferenciação traz informação sobre o nível de miscigenação, na medida em que a população miscigenada terá uma menor diferenciação genética em relação à parental que contribui mais para sua ancestralidade 
(Boca \& Rosenberg, 2011).

Para tanto, foram estimadas as distâncias genéticas entre a população de Belém e as parentais, tanto para o conjunto de STR do MHC como para os genômicos. As diferenças entre os valores de $\mathrm{F}_{\mathrm{ST}}$ entre os dois grupos foi usada para fazer inferências sobre diferenças na ancestralidade entre essas duas regiões do genoma. A significância estatística dessas diferenças foi testada através de permutações, cujos passos são descritos a seguir.

1- Foi estimamos o $\Delta \mathrm{F}_{\mathrm{ST}}$, definido com a diferença entre o $\mathrm{F}_{\mathrm{ST}}$ Genômico e o $\mathrm{F}_{\mathrm{ST}}$ do MHC de um determinado par de amostras populacionais. Por exemplo, o $\Delta \mathrm{F}_{\mathrm{ST}}$ obtido para o contraste entre Belém e Ameríndios, usando os STR do MHC, foi comparado com o $\Delta \mathrm{F}_{\mathrm{ST}}$ obtido para o mesmo par com os STR espalhados pelo genoma;

2- Para testar se os $\Delta \mathrm{F}_{\mathrm{ST}}$ eram significativamente diferentes de zero, indicando que os valores de $\mathrm{F}_{\mathrm{ST}}$ da região do $\mathrm{MHC}$ era significativamente diferentes do restante do genoma, geramos uma distribuição de valores de $\Delta \mathrm{F}_{\mathrm{ST}}$ esperados sob a hipótese nula de não haver diferença entre as duas regiões para essa estimativa. Isso foi realizado através de teste de aleatorização com os seguintes passos:

a. O conjunto total de STR (Genômicos e MHC) foi aleatoriamente dividido em dois grupos, sendo um com 54 marcadores e outro com sete marcadores, correspondendo ao número de STR genômicos e do MHC, respectivamente.

b. A cada aleatorização, um valor de $\Delta \mathrm{F}_{\mathrm{ST}}$ era calculado;

c. O processo foi repetido 10000 vezes, gerando uma distribuição de valores de $\Delta \mathrm{F}_{\mathrm{ST}}$, sob a hipótese nula. 
3- O p-valor foi definido como a proporção dos dados aleatorizados que tinham um $\Delta \mathrm{F}_{\mathrm{ST}}$ mais extremo do que aquele observado pela partição real dos dados (Genômicos versus MHC). Valores de p menores do que 0,05 foram tomados como indicação de que há diferença significativa entre os dois conjuntos de STR.

As simulações e comparações de diferenças nas distâncias genéticas foram implementadas com o pacote estatítico $R$.

\subsection{7- Comparação das proporções de ancestralidade}

Para testar se as diferenças entre as proporções de ancestralidade estimadas para a região do $\mathrm{MHC}$ em relação ao restante do genoma eram significativas, utilizamos o teste pareado de Wilcoxon, assumindo a hipótese nula de ausência de diferenças nas ancestralidades entre os dois grupos de marcadores.

Para testar a correlação entre as estimativas de ancestralidade medidas nas diferentes regiões genômicas, foi estimado o coeficiente de correlação de Spearman.

Os três teste foram realizados com o auxilio do programa BioEstat v5.0. 


\section{4-Resultados}

\section{1- Desvios de Hardy Weinberg}

Das 244 proporções genotípicas analisadas nas quatro populações para os 61 marcadores, $10 \%$ apresentaram desvios significativos de Hardy-Weinberg após correção para múltiplos testes $\left(p_{c}<0,05\right)$ (Tabela 19), sendo todos os desvios caracterizados por excesso de homozigotos. Quando separamos os desvios por tipo de marcador, a proporção fica em 7,8\% para genômicos e 28,5\% para MHC. Os únicos marcadores que apresentaram desequilíbrio de Hardy-Weinberg em mais de uma população foram os do MHC: STR-MICA (para portugueses e ameríndios), D6S2968 (para Belém e ameríndios) e D6S2972 (para africanos e ameríndios) (Tabela 19). Na Tabela 3A do Apêndice 1 encontram-se os valores de $p$ e $p_{c}$ (valor de $p$ corrigido) para todos os loci estudados.

A população que apresentou mais desvios foi a parental ameríndia $(12 / 61,20 \%)$, seguida da população de Belém (4/61, 7\%).

Como a amostra parental ameríndia é constituída pelo agrupamento de diferentes populações amazônicas, já era esperado que ocorresse um desvio das proporções de Hardy-Weinberg em função do efeito de Wahlund (Hartl e Clark, 2007). Por conta disso, realizamos também o teste com populações ameríndias individualmente, e nesse caso houve desvio apenas para dois marcadores do MHC em duas populações: UrubuKa'por $\left(D 6 S 2811 ; p_{c}=0,019\right)$ e Awa-Guajá $\left(S T R-M I C A ; p_{c}=0,027\right)$. Para os STR genômicos, houve desvios significantes, mas que foram perdidos após a correção para múltiplos testes (tabelas 5A a 6B no Apêndice). 
Tabela 19. Marcadores que apresentaram desvios de Hardy-Weinberg nas diferentes populações.

\begin{tabular}{|c|c|c|c|}
\hline População & Locus & Tipo de STR & $\mathbf{p}_{\mathrm{c}}$ \\
\hline \multirow[t]{5}{*}{ Belém } & D6S265 & MHC & 0,0021 \\
\hline & D7S821 & Genômico & 0,0038 \\
\hline & D8S2324 & Genômico & 0,0265 \\
\hline & D6S2968* & MHC & 0,0000 \\
\hline & G51152 & MHC & 0,0316 \\
\hline \multirow[t]{2}{*}{ Africanos } & D6S2972* & $\mathrm{MHC}$ & 0,0033 \\
\hline & STR-MICA* & MHC & 0,0342 \\
\hline Europeus & D3S3039 & Genômico & 0,0000 \\
\hline \multirow{11}{*}{ Ameríndios } & D3S1763 & Genômico & 0,0000 \\
\hline & $D 1 S 1660$ & Genômico & 0,0389 \\
\hline & D8S1128 & Genômico & 0,0000 \\
\hline & D9S1121 & Genômico & 0,0022 \\
\hline & D9S1122 & Genômico & 0,0016 \\
\hline & D9S934 & Genômico & 0,0038 \\
\hline & $N A D 1 S \_3$ & Genômico & 0,0092 \\
\hline & D6S2928* & MHC & 0,0014 \\
\hline & D6S2972* & $\mathrm{MHC}$ & 0,0452 \\
\hline & D6S2811 & MHC & 0,0006 \\
\hline & STR-MICA* & $\mathrm{MHC}$ & 0,0000 \\
\hline
\end{tabular}

*Marcador em desequilíbrio de HW em mais de uma população

Com o intuito de avaliar o impacto do desequilíbrio de Hardy-Weinberg nas estimativas de ancestralidade obtidas pelo STRUCTURE, comparamos os resultados de análises feitas com a base de dados completa e a base de dados de STR genômicos com desvios removidos. A correlação entre os bancos foi positiva e significante $(p<0,0001)$, (Figura 15). Isso significa que não houve alteração significativa nos valores de ancestralidade devido aos desvios de Hardy-Weinberg. Essa análise não foi feita para STR do MHC, dado o número reduzido de marcadores na região. 
Africana

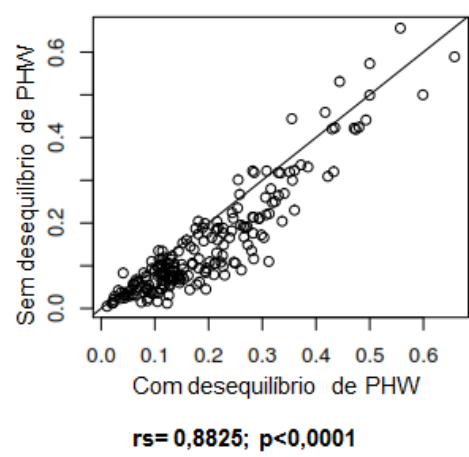

Europeia

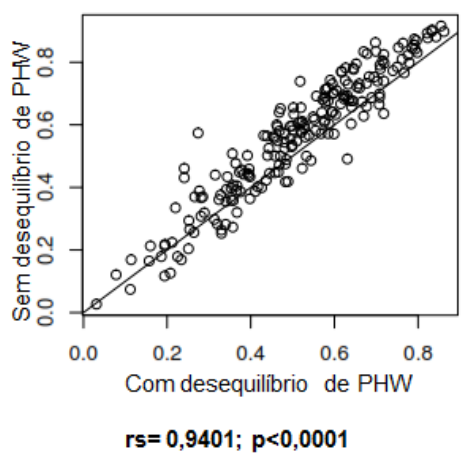

$r s=0,9401 ; p<0,0001$
Ameríndia

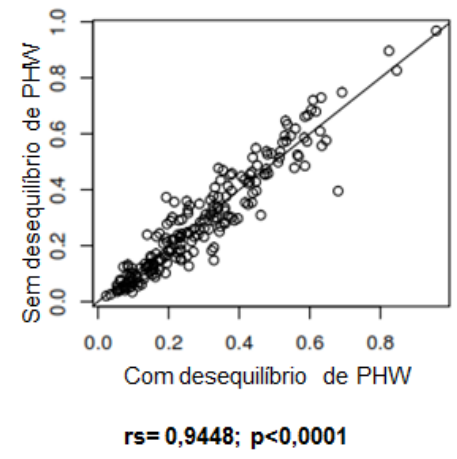

Figura 15: Gráficos de correlação das proporções de ancestralidade africana, europeia e ameríndia obtidas pelo banco de dados com marcadores desviados para as proporções de Hardy-Weinberg (PHW) com as do banco sem desvio.

\section{2- Índices de Diversidade}

Os índices de diversidade (He, $\theta \mathrm{H}$ e número de alelos) estão apresentados na Tabela 20 e nas Figuras 16 e 17, e os dados por lócus estão na Tabela A2 do Apêndice 1.

Os valores para todos os índices de diversidade são maiores para os STR do MHC em relação aos genômicos (Tabela 20), com exceção da taxa média de heterozigose $(\mathrm{He})$ para Ameríndios e do numero médio de alelos $(\mathrm{k})$ para a população de Belém ( $\triangle$ negativos). 
Tabela 20. Média dos índices de diversidade genética e Delta (4) para os STR Genômicos e do MHC medidos para Africanos, Europeus, Ameríndios e Belém.

\begin{tabular}{lllllllllll}
\hline \multirow{2}{*}{ Populações } & \multicolumn{4}{c}{ He } & \multicolumn{3}{c}{$\mathbf{\theta H}$} & \multicolumn{3}{c}{ K } \\
& Gen. & MHC & $\boldsymbol{\Delta}$ & Gen. & MHC & $\boldsymbol{\Delta}$ & Gen. & MHC & $\boldsymbol{\Delta}$ \\
\hline Africanos & $\mathbf{0 . 7 4}$ & 0.76 & 0.02 & $\mathbf{3 . 2 0}$ & 4.29 & 1.09 & 5.44 & 7.00 & $\mathbf{1 . 5 6}$ \\
Europeus & $\mathbf{0 . 7 4}$ & $\mathbf{0 . 7 8}$ & $\mathbf{0 . 0 4}$ & 3.12 & $\mathbf{5 . 2 6}$ & $\mathbf{2 . 1 3}$ & 5.76 & 7.00 & 1.24 \\
Ameríndios & 0.68 & 0.66 & -0.02 & 2.34 & 2.76 & 0.42 & 6.41 & $\mathbf{7 . 8 6}$ & 1.45 \\
Belém & $\mathbf{0 . 7 4}$ & $\mathbf{0 . 7 8}$ & $\mathbf{0 . 0 4}$ & 3.08 & 4.99 & 1.91 & $\mathbf{7 . 7 8}$ & 6.57 & -1.21 \\
Média & 0.73 & 0.74 & - & 2.94 & 4.32 & - & 6.35 & 7.11 & - \\
\hline
\end{tabular}

Gen-STR Genômicos; MHC- STR MHC; He- taxa de heterozigose média; $\theta \mathrm{H}$ $4 \mathrm{~N} \mu ; \Delta$ - medida que representa a diferença entre os índices obtidos pelos microssatélites do MHC subtraídos dos índices de microssatélites genômicos e K representa o número médio de alelos Os maiores valores estão destacados em negrito.

Dentre os marcadores do MHC com maior diversidade, podemos destacar o D6S2811 (HLABC-CA) que aparece com os índices de diversidade elevados em todas as quatro populações (Figura 17).

Para os STR genômicos, há uma redução da diversidade genética em ameríndios com relação às outras populações. O único índice que não segue essa tendência é o de número médio de alelos, que foi o segundo maior valor dentre os observados para essa população parental $(\mathrm{k}=6.41)$ (Figura 16) 


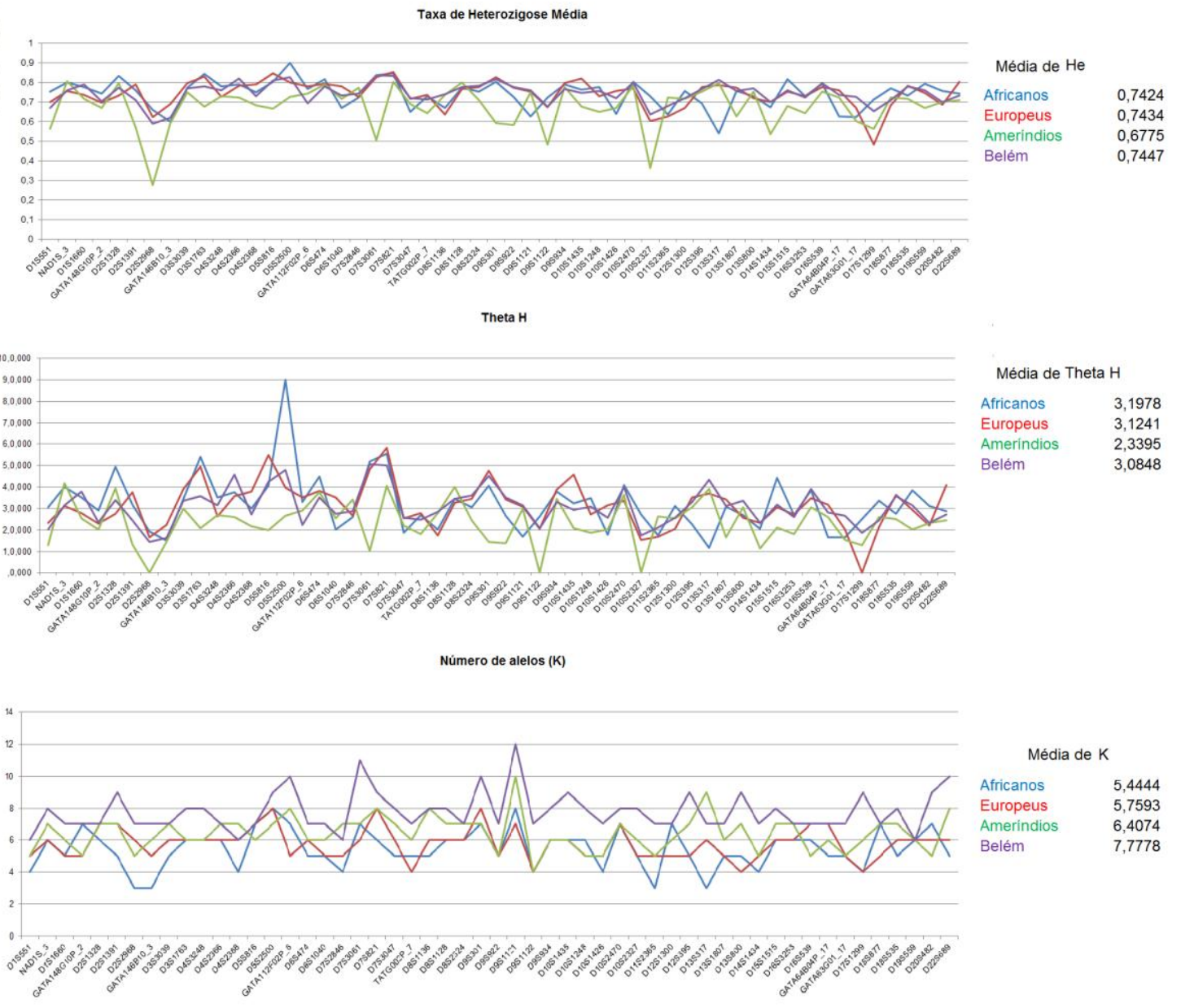

Figura 16: Índices de diversidade genética para cada STR Genômico e a média nas populações parentais e na população miscigenada de Belém. He: taxa de heterozigose esperada; Theta $\mathrm{H}$ : estimativa de $(4 \mathrm{~N} \mu), \mathrm{K}$ : número de alelos. 
Taxa de Heterozigose média

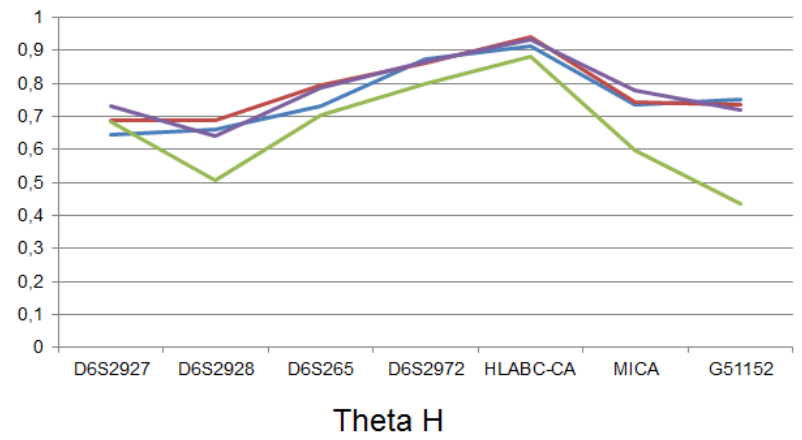

Média de $\mathrm{He}$

Africanos $\quad 0,7588$

Europeus $\quad 0,7800$

Amerindios $\quad 0,6588$

Belém $\quad 0,7799$

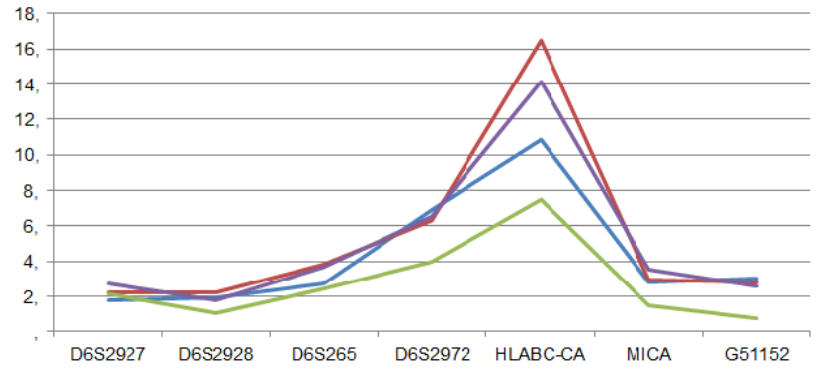

Média de Theta $\mathrm{H}$

Africanos $\quad 4,2863$

Europeus $\quad 5,2567$

Amerindios $\quad 2,7608$

Belém $\quad 4,9949$

Número de alelos

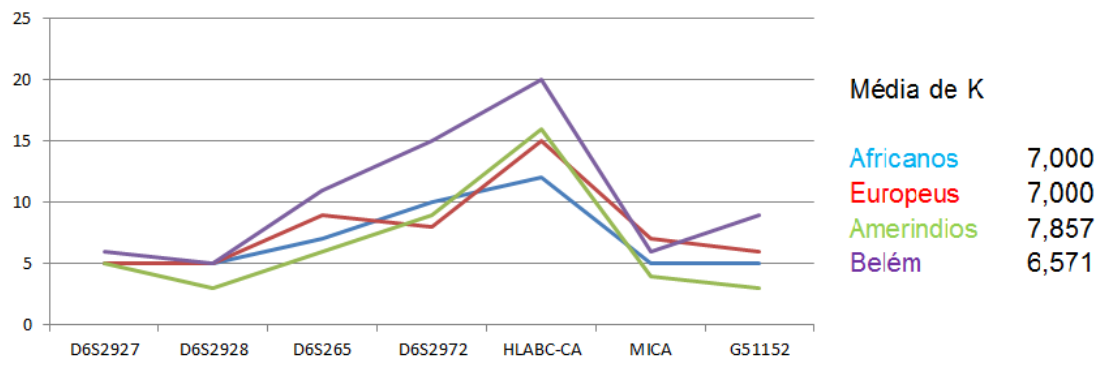

Figura 17: Índices de diversidade genética para cada STR do MHC e os valores médios nas populações parentais e na população miscigenada de Belém. He- taxa de heterozigose esperada; Theta $\mathrm{H}$ - taxa de heterozigose esperada em um cenário de equilíbrio entre mutação e deriva: K- número de alelos. A ordem dos STR não reflete sua disposição física no cromossomo. 


\section{3-Validação dos STR com estimadores de ancestralidade}

A confiabilidade dos STR como estimadores de ancestralidade foi testada usando os resultados obtidos, para a mesma amostra, por um conjunto independente de 47 marcadores do tipo INDEL já caracterizados como informativos de ancestralidade (Santos et al., 2010).

A correlação de Spearman entre os componentes de ancestralidade individual, estimados pelos micros e pelos INDEL, mostrou-se positiva e significante (Figura 18), e a ancestralidade média para cada componente é muito semelhante entre ambos os marcadores (Tabela 21)
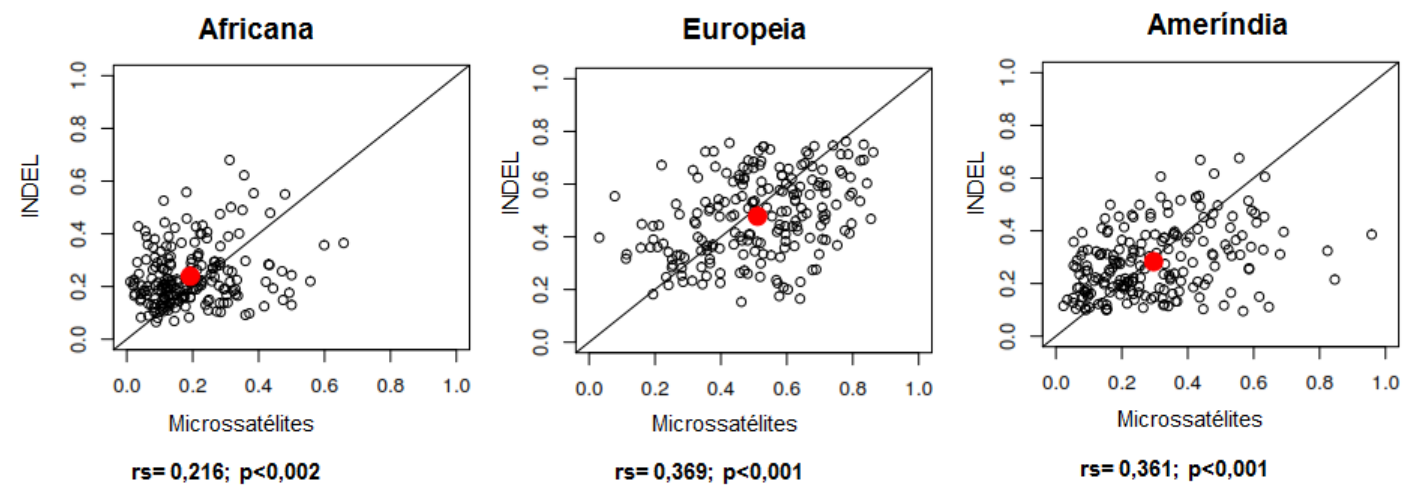

Figura 18: Gráficos de correlação das proporções de ancestralidade africana, europeia e ameríndia estimadas por INDELs e os STR genômicos. Os pontos vermelhos indicam as ancestralidades médias para as estimativas de ancestralidade obtidas com cada conjunto de marcadores. 


\section{4-Análise de ancestralidade}

A Tabela 21 apresenta as ancestralidades médias para a população miscigenada de Belém, obtidas a partir dos STR Genômicos, STR do MHC e INDEL (Pedroza et al., 2011).

Tabela 21. Média das ancestralidades africana, europeia e ameríndia estimadas na amostra de Belém por STR Genômicos, MHC e INDEL.

\begin{tabular}{llll}
\hline \multirow{2}{*}{ Referência } & \multicolumn{3}{c}{ Ancestralidade } \\
& Africana & Europeia & Ameríndia \\
\hline STR Genômicos* & 0,19 & 0,51 & 0,30 \\
STR MHC $^{*}$ & 0,23 & 0,67 & 0,11 \\
INDEL** & 0,22 & 0,50 & 0,28 \\
\hline
\end{tabular}

* Presente estudo; **Pedroza et al. (2012)

É possível perceber uma redução na ancestralidade média para o componente ameríndio no MHC em relação ao observado para o restante do genoma, que se mostrou estatisticamente significativa (Wilcoxon; $Z=8,9573 ; \mathrm{p}<0,0001$ ). Essa diminuição da ancestralidade ameríndia é acompanhada por um concomitante aumento da contribuição européia (Wilcoxon; $Z=7,5626 ; \mathrm{p}<0,00001$ ) e africana (Wilcoxon; $Z=2,6112$ : $p=$ 0,0090).

A Figura 19 ilustra essa redução da contribuição ameríndia e aumento substancial da contribuição europeia. Na Figura 20, é possível peceber o aumento da variancia e de a perda brusca de ancestralidade ameríndia pelo acúmulo de valores proximos de zero. 

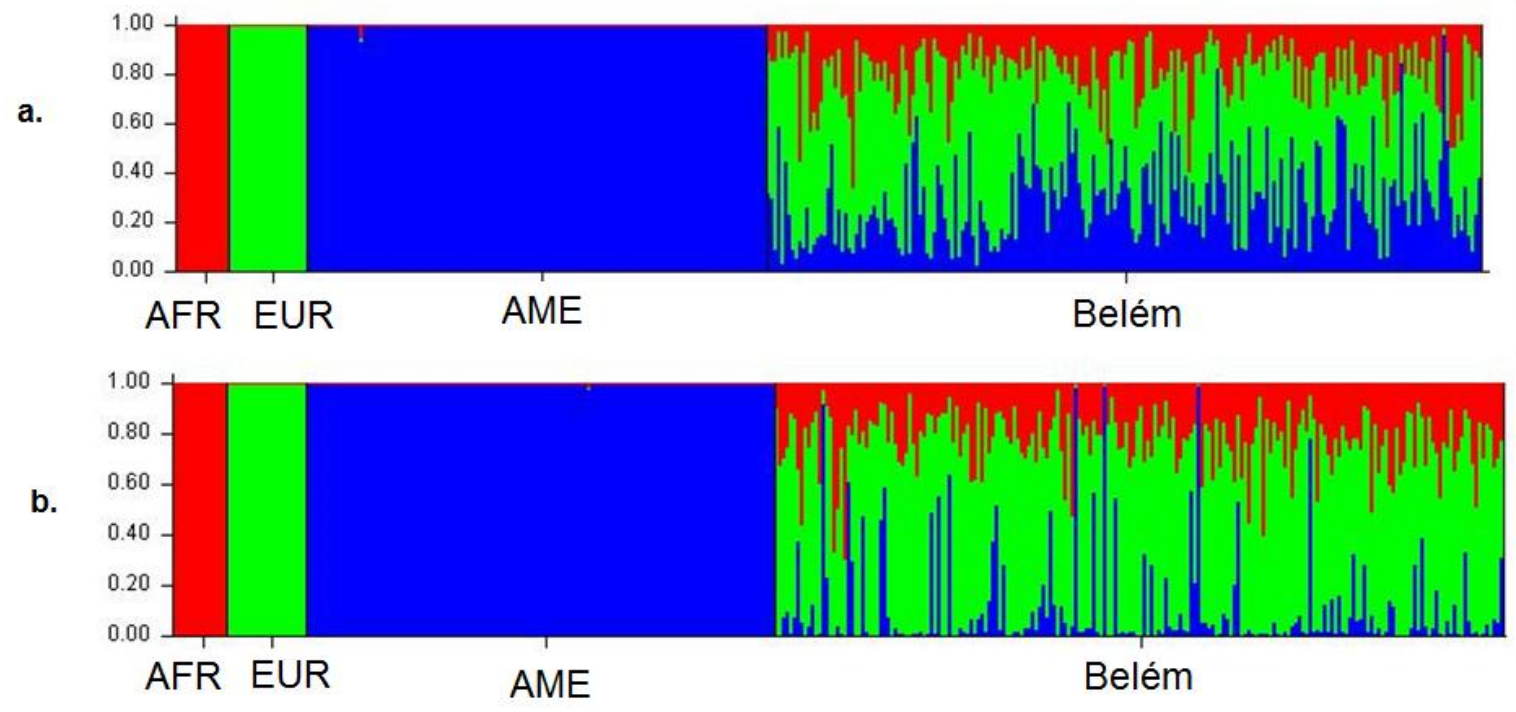

Figura 19: Representação gráfica das proporções individuais de ancestralidade na população de Belém. AFR: indivíduos da população parental africana; EUR: indivíduos da população parental europeia; AME: Indivíduos da população parental ameríndia. Cada linha vertical da figura de barras representa um indivíduo, que aparecem na mesma ordem nos dois gráficos. Na população miscigenada de Belém as cores vermelho, verde e azul correspondem, respectivamente, às proporções de ancestralidade africana, europeia e ameríndia a. Estimativas de miscigenação individual com os 54 marcadores STR genômicos. b. Estimativas de miscigenação individual para os 7 marcadores STR do MHC. 

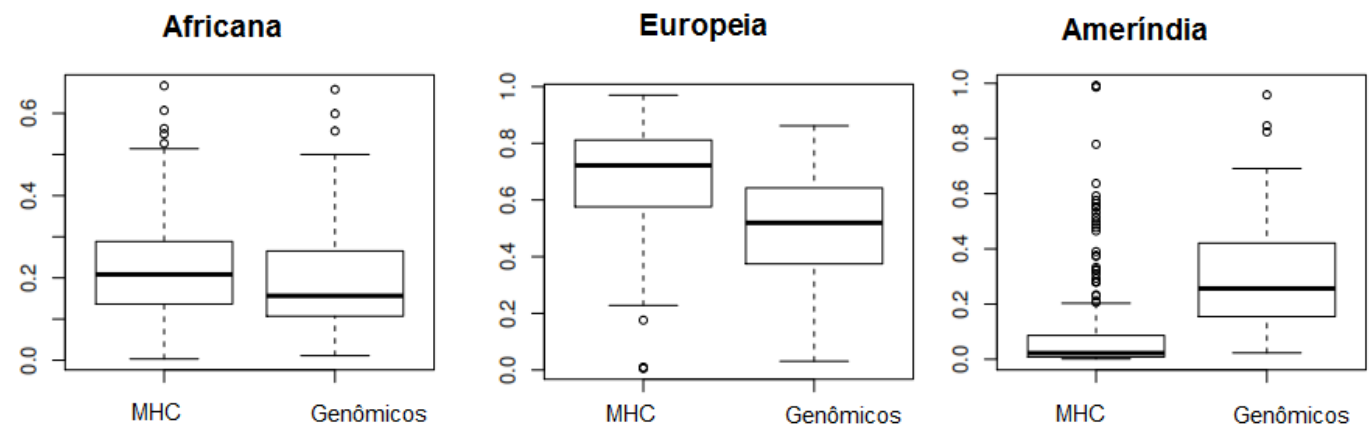

Figura 20: Box Plot dos valores de ancestralidade individuais, obtidos pelos diferentes marcadores na população de Belém. MHC- STR do MHC; GEN- STR genômicos.

\section{5-Correlação entre proporções de ancestralidade no Genoma e MHC}

A correlação de Spearman entre as proporções de ancestralidade estimadas por STR genômicos e do MHC para cada indivíduo é significativa apenas para o componente ameríndio $\left(\mathrm{r}_{\mathrm{s}}=0,1885 ; p=0,0072\right)$, sendo não significativa para os componentes europeu $\left(\mathrm{r}_{\mathrm{s}}=0,1153 ; p=0,1023\right)$ e africano $\left(\mathrm{r}_{\mathrm{s}}=-0,0148 ; p=0,8348\right)$.

Espera-se que o processo de miscigenação tenha causado um impacto homogêneo no genoma como um todo, ou seja, que as proporções de ancestralidade sejam correspondentes às proporções de contribuição de cada população parental, em qualquer região do genoma. No entanto, para a população miscigenada em questão, este resultado indica haver diferenças nas proporções de ancestralidade obtidas na região do MHC com o restante do genoma.

A ausência de correlação entre essas duas medidas de ancestralidade individual são consistentes com a alta variância (Figura 20) nos valores de ancestralidade que estimamos usando diferentes painéis de marcadores genômicos para os mesmo indivíduos, indicando que para o número de marcadores que estamos usando, ainda que 
estimativas populacionais sejam validadas por dados independentes, estimativas individuais são muito variáveis. Em teoria esperamos que tal variância reduza o poder estatístico de nossa comparação. Entretanto, encontramos uma diferença significativa entre a ancestralidade ameríndia no MHC e no restante do genoma.

Como o MHC apresenta ligação entre seus marcadores, fator que diminui a confiabilidade de inferências individuais usando o modelo de miscigenação do programa STRUCTURE (Material e métodos), optamos pela inclusão de uma segunda estratégia, que não utiliza o programa STRUCTURE, e é menos suscetível aos efeitos de ligação entre marcadores na região do MHC. Essa abordagem consiste no uso de diferenciação populacional para fazer inferências sobre perfis de miscigenação (Boca e Rosenberg, 2011).

\section{6-Diferenciação populacional}

Os valores de $\mathrm{F}_{\mathrm{ST}}$ estimados entre pares de populações para os STR do MHC foram maiores do que os estimados a partir dos STR genômicos em quatro comparações: (Africana versus Amerindia, Africana versus Belém, Europeia versus Ameríndia e Amerindia versus Belém), e menor em duas África versus Europa ( $\mathrm{F}_{\mathrm{ST}}$ genômico $\left.=0,02239 ; \mathrm{F}_{\mathrm{ST}} \mathrm{MHC}=0,00048\right)$ e Europa versus Belém $\left(\mathrm{F}_{\mathrm{ST}}\right.$ genômico= 0,00853; $\mathrm{F}_{\mathrm{ST}} \mathrm{MHC}=0,00603$ ). $\mathrm{O}$ maior $\Delta \mathrm{F}_{\mathrm{ST}}$ (diferença entre o valor de $\mathrm{F}_{\mathrm{ST}}$ genômicos e MHC) observado foi o obtido das comparações entre América e Belém $\left(\Delta_{\mathrm{FST}}=\right.$ 0,0545), seguido da diferença entre Europa e América $\left(\Delta_{\mathrm{FST}}=-0,04840\right)$ (Tabela 22).

$\mathrm{O}$ teste de significância dos valores de $\Delta \mathrm{F}_{\mathrm{ST}}$ revelou que apenas a diferença entre América e Belém é significante $(\mathrm{p}=0,022)$. A representação gráfica da distribuição nula $\operatorname{dos} \Delta \mathrm{F}_{\mathrm{ST}}$ estão nas Figura 21. 
Tabela 22. Valores de $\mathrm{F}_{\mathrm{ST}}$ para os pares de populações e o $\Delta \mathrm{F}_{\mathrm{ST}}$ obtido pela diferença entre o $\mathrm{F}_{\mathrm{ST}}$ genômicos e $\mathrm{F}_{\mathrm{ST}}$ do $\mathrm{MHC}$

\begin{tabular}{cccc}
\hline Par de populações & F $_{\text {ST }}$ Genômico & F $_{\text {ST }}$ MHC & $\boldsymbol{\Delta}$ FST \\
\hline Africana x Europeia & 0,0224 & 0,0005 & 0,0219 \\
Africana x Amerindia & 0,0719 & 0,0939 & $-0,0220$ \\
Africana x Belém & 0,0219 & 0,0259 & $-0,0040$ \\
Europeia x Ameríndia & 0,0576 & 0,1060 & $-0,0484$ \\
Europeia x Belém & 0,0085 & 0,0060 & 0,0025 \\
Amerindia x Belém & 0,0368 & 0,0913 & $-0,0545$ \\
\hline
\end{tabular}

A.

Diferença entre os FSTs Africa x Belém

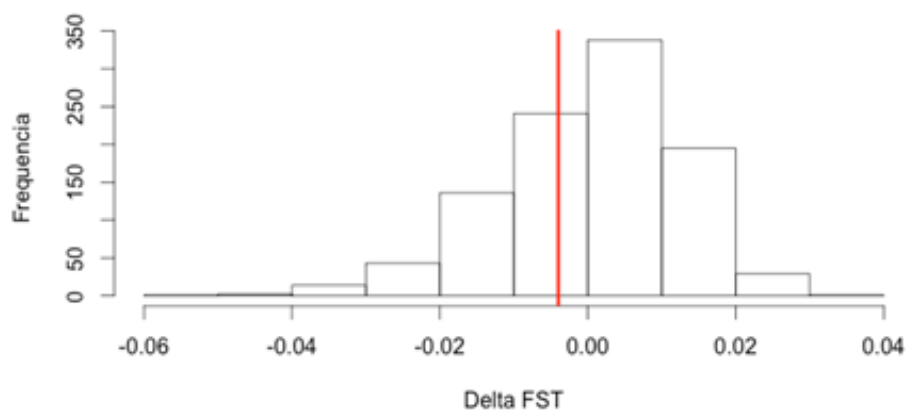

B.

Diferença entre os FSTs Europa x Belém

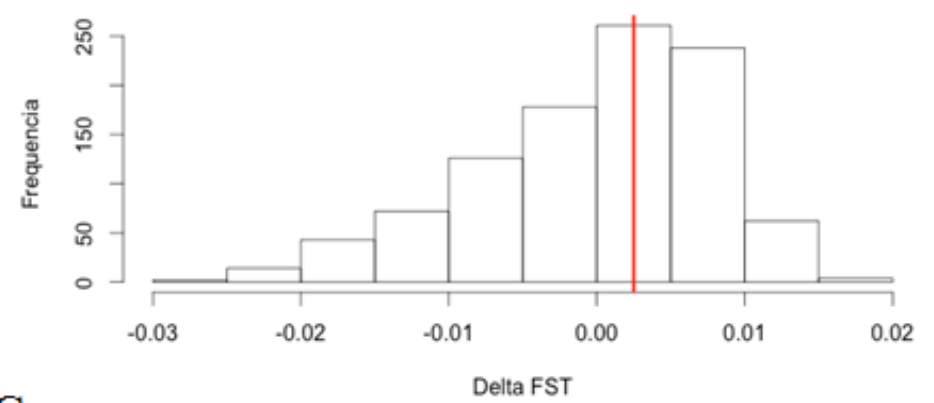

C.

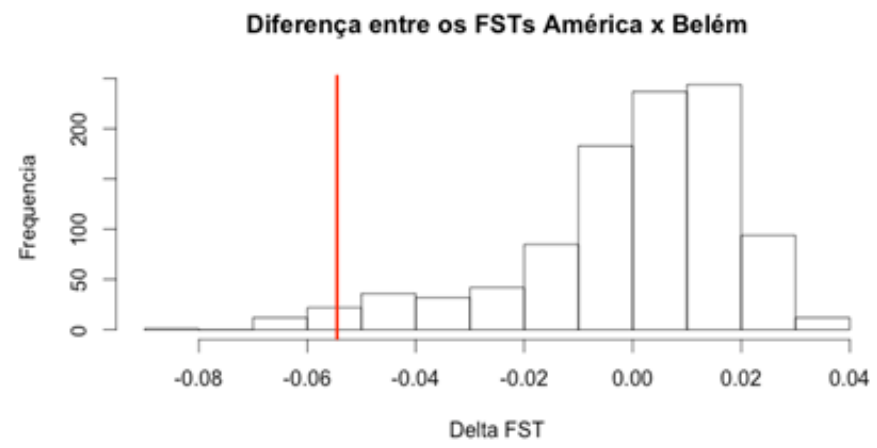

Figura 21: Teste de aleatorização de valores de $\Delta \mathrm{F}_{\mathrm{ST}}$. A linha vermelha indica o valor observado. A.- $\Delta \mathrm{F}_{\text {ST }}$ para os pares África x Belém; B.- $\Delta \mathrm{F}_{\mathrm{ST}}$ para os pares Europa x Belém; C.- $\Delta \mathrm{F}_{\mathrm{ST}}$ para os pares Ameríndio x Belém 
Os achados para a análise baseada em $\mathrm{F}_{\mathrm{ST}}$ são consistentes com os de componentes de ancestralidade, na medida em que mostram que a maior diferença de $\mathrm{F}_{\mathrm{ST}}$ do MHC e Genômico existe para o componente ameríndio, que apresenta maior distancia da população miscigenada.

\section{5 -Discussão}

Diferentes metodologias têm sido aplicadas para a detecção dos sinais deixados pela seleção natural no genoma, em diferentes escalas de tempo (revisão em Garrigan e Hedrick, 2003; Bamshad e Wooding, 2003). Nos últimos anos, os desvios de proporções de ancestralidade no genoma de populações miscigenadas americanas têm sido usados como ferramentas de detecção de sinais recentes da atuação da seleção natural (Long 1991, Tang et al., 2006, Basu et al., 2008).

Nesse tipo de abordagem, espera-se que as estimativas de ancestralidade observadas no genoma como um todo sejam um reflexo da proporção de contribuição dos grupos parentais para a formação das populações miscigenadas. Quando algum desvio de ancestralidade é detectado, uma das interpretações é a de que, ao longo da formação das populações miscigenadas, pressões seletivas favoreceram (ou selecionaram contra) um haplótipo parental específico (europeu, africano ou ameríndio).

No presente estudo, utilizamos marcadores do tipo microssatélite para estimar as proporções de ancestralidade africana, europeia e ameríndia na população tri-hibrida de Belém, para diferentes regiões do genoma e em especial na região do MHC (candidata à 
apresentar sinais de seleção). Nossos resultados apontam para um desvio significativo no sentido de redução da ancestralidade ameríndia na região do MHC da população de Belém.

No entanto, é necessário que se discutam alguns aspectos importantes da metodologia aplicada neste estudo e suas limitações, para que seja possível compreender sua influência nos resultados e na interpretação dos mesmos.

\section{1-Desvios de Hardy-Weinberg}

As proporções genotípicas dos 54 STR genômicos e sete do MHC nas quatro populações revelaram $7,8 \%$ e $28,9 \%$, respectivamente, de desvios do esperado em equilíbrio de Hardy-Weinberg. Nunes (2011) observou, para um conjunto um pouco maior desses marcadores, valores de 5,9\%\% e 14,9\% para genômicos e MHC, respectivamente.

O tamanho amostral e o número de marcadores utilizados na caracterização da variação do MHC entre os dois trabalho foi diferente. Enquanto Nunes (2011) usou 16 marcadores, o presente estudo se restringiu a um subconjunto desses marcadores, composto por sete STR adjacentes aos genes HLA (Figura 14).

\subsection{1-Influência dos marcadores com desvios de Hardy-Weinberg}

O teste envolvendo a remoção dos STR genômicos que se encontravam em desvio de Hardy-Weinberg (Figura 15) foi importante, pois o algoritmo de análise 
bayesiana implementado no programa STRUCTURE utiliza os desvios de HardyWeinberg, durante as sucessivas re-amostragens dos indivíduos, como parâmetro para a definição das proporções de ancestralidade (Pritchard et al., 2000).

Uma preocupação era a de que a redução do componente ameríndio observada na região do MHC, em relação ao restante do genoma, estaria associada à contribuição de STR genômicos em desequilíbrio de Hardy-Weinberg, que gerariam um incremento relativo dessa ancestralidade no genoma como um todo, intensificando assim, o sinal de redução de componente ameríndio no MHC.

No entanto, o resultado desse teste mostrou que houve uma pequena redução da ancestralidade africana no banco de dados sem loci com desvios de Hardy-Weinberg, além de um pequeno incremento na ancestralidade europeia. Sendo que a correlação entre as ancestralidades ameríndias em ambos os bancos de dados foi quase total.

Esses resultados mostram que o desvio acentuado que se observa na comparação entre a região do $\mathrm{MHC}$ e restante do genoma para ancestralidades ameríndia e europeia não deve ter sido ocasionado por algum viés introduzido pelos STR genômicos que apresentaram desvio de Hardy-Weinberg na população parental ameríndia.

\subsection{2- Influência da amalgamação de populações}

Quando testamos as populações ameríndias individualmente, verificamos que nenhum marcador apresentou desvios no equilíbrio de Hardy-Weinberg. Isso é coerente com o argumento de que o principal motivo para os desvios na população parental ameríndia seja a amalgamação de populações isoladas (efeito Wahlund), que gera um excesso de homozigotos, exatamente o que foi observado para a população parental ameríndia. 
Um desdobramento necessário para as análises futuras será a determinação da contribuição de cada uma dessas populações nativas amazônicas para a composição do componente ameríndio da população de Belém.

\section{2-Influência do desequilíbrio de ligação entre os STR}

A não independência entre os marcadores do MHC, resultante de sua colocalização numa mesma região genômica, influencia nossa análise. Primeiro, o método implementado no programa STRUCTURE tem precisão reduzida quando há ligação física entre marcadores. Segundo, os métodos de permutação aleatorizam loci, e não conjuntos de loci, de modo que nossas distribuições nulas não contemplam os efeitos de desequilíbrio de ligação.

Essas dificuldades só poderiam ser superadas caso utilizássemos uma painel denso de marcadores, permitindo controlar para efeitos de desequilíbrio de ligação ao amostrar marcadores similarmente ligados fora da região do $\mathrm{MHC}$, ou ainda reamostrando marcadores do MHC, mas escolhendo apenas subconjuntos não ligados.

O possível desequilíbrio de ligação entre os marcadores do MHC pode aumentar, por acaso, a probabilidade de haver diferenças entre genômicos e MHC, uma vez que na prática essa região está tendo sua ancestralidade estimada por poucos marcadores nãoindependentes. 


\section{3- Análises para validação dos resultados}

Uma vez que nossos resultados dependem de modo crítico da confiabilidade de nossas estimativas de ancestralidade, utilizamos duas abordagens para valida-los.

A primeira abordagem consistiu em comparar as ancestralidades estimadas para a mesma amostra, porém num conjunto de marcadores do tipo INDEL caracterizados como AIM (Pedroza et al., 2011). Essa genotipagem foi realizada após termos iniciado o nosso projeto, motivada pela necessidade de controlar a amostra de Belém para diferenças de ancestralidade em relação a grupos de indivíduos com doenças sendo estudadas num desenho de caso-controle. As correlações demonstraram alta variância nas estimativas de ancestralidade individual, porém as correlações são altamente significativas $(\mathrm{p}<0,002)$ em todos os casos (Figura 18). Além disso, as médias populacionais das estimativas são muito semelhantes, mostrando que as estimativas não apresentam viés na direção de uma determinada ancestralidade (Tabela 20).

A segunda abordagem, baseada na distância genética entre as amostras é menos sensível aos efeitos de ligação e apresentou resultados qualitativamente concordantes com aqueles obtidos pelas análises do programa STRUCTURE (Tabela 22).

\section{4- Diversidade genética}

Todos os índices de diversidade genética se revelaram maiores na região MHC em relação ao restante do genoma. Para as populações ameríndias, esse resultado é inverso ao observado por Nunes (2011), que detectou valores maiores dos índices de diversidade para os STR genômicos. 
Uma explicação para isso pode ser a escolha enviesada dos STR do MHC: apenas marcadores muito próximos aos genes HLA fizeram parte das nossas análises. A outra explicação é a de que a média de diversidade maior no MHC está associada ao microssatélite $D 6 S 2811(H L A B C-C A)$, que foi o marcador que apresentou os maiores índices de diversidade em todas as populações (Figura ). Uma terceira explicação, é que ao amalgamarmos as populações ameríndias isso pode ter agrupado diferentes alelos de diversas populações, o que pode levar ao aumento da diversidade na população ameríndia parental.

Algo que também pode explicar o aumento da diversidade em MHC com relação ao resto do genoma é o fato de os marcadores escolhidos terem motivos de repetição de natureza diferente. Os marcadores genômicos são todos tetranucleotídeos e enquanto que quatro dos sete marcadores do MHC são dinucleotídeos e um é um trinucleotídeo imperfeito (STR-MICA). A preocupação se deve pelos relatos de que existe uma influência do tamanho do motivo de repetição na taxa de mutação dos STR: quanto menor o motivo, maior a taxa de erro durante a replicação do DNA .( Eisen, 2001). Portanto, para os STR com menores unidades de repetição, a diversidade tende a ser maior. Nunes (2011) testou essa hipótese usando os valores de $\mathrm{F}_{\mathrm{ST}}$ e, apesar de ter visto uma tendência de maior diferenciação para STR dinucleotídeos espalhados pelo genoma quando comparado com tetranucleotídeos, essa diferença não foi significante( $p=0,3)$.

No presente estudo observamos um traço muito bem documentado em populações ameríndias: a menor variabilidade genética nessas populações (Wang et al., 2007, Cavalli-Sforza et al., 1993). Esse padrão, refletido nos valores de theta, não é incompatível com a possibilidade de que a seleção recente tenha alterado os perfis de ancestralidade, conforme argumentaremos adiante, uma vez que evidências de seleção e 
a forte influência da demografia podem ser simultaneamente visíveis em dados, desde que sejam utilizados métodos sensíveis aos desvios causados por cada um desses processos (demografia e seleção).

\section{5- Estimativas de Ancestralidade}

\subsection{1-Estimativas de ancestralidade genômica}

As proporções de ancestralidade estimadas a partir do programa STRUCTURE, com o uso de STR genômicos (0,19 africana, 0,51 europeia e 0,30 ameríndia), revelaram um cenário compatível de contribuição das ancestralidades africana, europeia e ameríndia com o descrito na literatura para populações de Belém. Nas últimas décadas, seis estudos descreveram as proporções de ancestralidade africana, europeia e ameríndia na população de Belém. Esses estudos sugerem que as ancestralidades variam entre 0,12 a 0,33 (africana), 0,48 a 0,61 (europeia) e 0,16 a 0,3 (ameríndia) (Santo et al. 2010; Franco 1973; Ayres et al. 1976, Schneider et al. 1979; Corvelo et al. 1984; Guerreiro et al. 1988).

O trabalho de Pedroza et al. (2011) foi desenvolvido com os mesmos indivíduos da população de Belém utilizada no presente estudo, com a diferença de que os autores fizeram uso do painel de AIM do tipo INDEL para estimar a ancestralidade. Esse painel foi padronizados por Santos (2010) que, por sua vez, também testou o painel de AIM em uma outra amostra populacional de Belém. Ambos os trabalhos estimaram as ancestralidades individuais dos indivíduos de Belém com o auxílio do programa STRUCTURE e usaram como populações parentais indivíduos da África subsaariana, 
portugueses, e uma amalgamam de populações ameríndias da Amazônia (Santos et al., 2011). As proporções de ancestralidade observados em cada estudo estão na Tabela 23.

Tabela 23. Estimativas de ancestralidade para Belém em diferentes estudos.

\begin{tabular}{llcccc}
\hline \multicolumn{1}{c}{$\begin{array}{c}\text { Tipo de } \\
\text { marcador }\end{array}$} & Referência & N & Africana & Europeia & Ameríndia \\
\hline STR & Presente estudo & 202 & 0,19 & 0,51 & 0,30 \\
AIM-INDEL & Santos et al. (2010) & 196 & 0,12 & 0,61 & 0,27 \\
AIM-INDEL & Pedroza et al. & 187 & 0,22 & 0,50 & 0,28 \\
& $(2011)$ & & & & \\
\hline
\end{tabular}

O teste de correlação realizado entre as ancestralidades obtidas pelos AIM em Pedroza et al., (2011) e as estimadas no presente trabalho foi positivo e significante $(\mathrm{p} \leq$ 0,002) mesmo utilizando marcadores e populações parentais diferentes. No entanto, a elevada variância observada nas estimativas indica que as ancestralidades médias obtidas para cada tipo de marcador podem ser parecidas, mas, individualmente, ainda há muita variação. Por outro lado, a diferença observada com relação ao estudo de Santos et al. (2010) é explicada pelo fato de os autores terem usado outra amostra de Belém.

Diante dessas comparações, podemos afirmar que os STR utilizados neste estudo são capazes de estimar a ancestralidade em populações miscigenadas de maneira confiável. Além disso, o conjunto de informações extraídas a partir dos STR é maior que para o conjunto de INDEL. A alta variabilidade genética dos microssatélites possibilita: (a) a estabelecer quais populações/regiões específicas contribuíram para a ancestralidade dos indivíduos, inclusive distinguindo entre populações ameríndias (análise que não realizamos ainda, mas que motivou o uso de microssatélites); (b) fazer 
análise do tipo $\mathrm{F}_{\mathrm{ST}}$ livre de viés de averiguação; (c) testar hipóteses demográficas (como gargalos e expansões populacionais, por exemplo).

\subsection{2-Desvios de ancestralidade entre o MHC e a média genômica}

Espera-se que a miscigenação impacte a variabilidade do genoma como um todo, da mesma forma que outros eventos demográficos como gargalos e expansões populacionais (Akey et al., 2009). Seguindo essa lógica, é possível identificar regiões sob seleção natural a partir da detecção de desvios nas proporções de ancestralidade nessas regiões quando comparadas ao restante do genoma (Tang et al., 2006; Basu et al., 2008).

Quando fizemos as comparações das ancestralidades genômicas com as ancestralidades obtidas pelos STR do MHC, observamos um desvio significante no sentido de redução da ancestralidade ameríndia (-19\%) e aumento das ancestralidades europeia $(+16 \%)$ e africana $(+3 \%)$.

Uma vez que há incertezas associadas às estimativas de ancestralidade para marcadores ligados, assim como o fato de termos encontrado correlações relativamente baixas entre diferentes estimativas (INDEL versus STR genômicos), algo que sugere que há considerável variância nas nossas estimativas de ancestralidade individual, optou-se por utilizar uma segunda abordagem com o objetivo de estimar a contribuição relativa de cada população parental para a amostra miscigenada sem a influência condicionante desses fatores.

Essa análise envolveu a quantificação da diferença dos valores de $\mathrm{F}_{\mathrm{ST}}$ para o MHC e o restante do genoma $\left(\Delta \mathrm{F}_{\mathrm{ST}}\right)$, que revelou haver uma distância genética 
significativamente maior para a região do $\mathrm{MHC}$, do que para a média genômica, na comparação entre Belém e ameríndios.

A perda do componente ameríndio e consequente aumento do componente europeu nas ancestralidades obtidas para o MHC fizeram com que, para esta região genômica, a diferenciação genética entre Belém e ameríndios aumentasse e entre Belém e europeus, diminuísse.

\section{6- Hipótese seletiva}

A menor proporção de ancestralidade ameríndia, e simetricamente, maior proporção de ancestralidade europeia e africana na região do MHC da população de Belém, pode resultar da ação da seleção natural favorecendo alelos europeus e africanos, em detrimento dos alelos ameríndios.

Estudos anteriores encontraram desvios de ancestralidade em diferentes regiões do genoma, inclusive no MHC. Em um estudo com a população do Porto Rico, Tang et al. (2007) detectaram a região do MHC como tendo um excesso de ancestralidade africana, e esse desvio foi confirmado pela análise das estimativas de ancestralidade obtidas por genes $H L A$, quando comparados com a ancestralidade média genômica. Johnson et al. (2011) analisaram trios de pais e filhos de amostras mexicanas provenientes da cidade do México e da cidade de Los Angeles e com base na análise de homozigose de haplótipo estendida, detectaram sinais de desvio de ancestralidade, principalmente para acréscimo do componente europeu. Usando STR espalhados por todo o genoma, Basu et al. (2008) detectaram duas regiões do genoma de mexicanos com um decréscimo significativo da ancestralidade africana e uma com aumento da ancestralidade europeia. 
No caso da população mexicana analisada por Basu et al (2008), não foi detectado sinal de desvios de ancestralidade na região do MHC devido à baixa densidade de marcadores nessa região.

Essa breve revisão das inferências sobre seleção natural que foram feitas a partir de informações sobre ancestralidade em populações miscigenadas da América, mostra claramente os desafios dessa abordagem.

Em primeiro lugar, estudos envolvendo populações distintas obtiveram resultados diferentes, ainda que em dois dos trabalhos citados a região do MHC tenha aparecido como potencial alvo de seleção natural. Entretanto, mesmo para a região do MHC, há diferenças entre as inferências a respeito de qual ancestralidade contribui em excesso, em relação à média genômica, para a ancestralidade no MHC. Essas diferenças podem estar relacionadas ao fato dos estudos terem usados métodos diferentes, e também ao fato de populações terem experimentado histórias demográficas e seletivas diferentes, de modo que genes distintos foram selecionados em cada uma, ou que variantes diferentes foram favorecidas em ambientes distintos.

\subsection{1- Seleção Natural no MHC}

A população nativa americana ficou isolada das populações europeias e africanas por mais de 10 mil anos. Durante esse período de isolamento as populações enfrentaram diferentes desafios adaptativos o que levou a diferentes histórias evolutivas.

Os europeus, por exemplo, domesticaram diversos animais que possuem agentes patológicos que são transmitidos ao homem (varíola, sarampo, gripe). Esse longo convívio entre homem e animais, selecionou indivíduos, não totalmente imunes as doenças transmitidas, mas capazes de gerar uma resposta imune que garantisse sua 
sobrevivência. A interligação entre os continentes europeus, asiáticos e africanos, facilitou o contato entre os povos e promoveu o intercambio dos patógenos e consequente estimulo imunológico dos indivíduos. Por outro lado, os povos nativos americanos não tiveram animais para domesticar e seu sistema imune foi estimulado a responder aos patógenos do continente americano (Guergel. 2010).

Portanto, é relevante considerar que a re-colonização das Américas por populações há tanto tempo isoladas umas das outras trouxe inúmeros novos desafios, incluindo seletivos. Nos relatos dos primeiros anos de ocupação portuguesa da região de Belém, é possível encontrar um primeiro embate entre os colonos portugueses e os índios Tupinambás que habitava a região do igarapé Piri (hoje local onde foi construído o mercado do Ver-o-peso) que culminou na morte de 1500 índios e 2 colonos (Simonian, 2012). Em seguida, existem inúmeros relatos de epidemias de Bexiga (varíola) e sarampo, que resultaram na morte de boa parte da população ameríndia que ali já havia se instalado. (Simonian, 2012)

Como já foi dito na introdução, os genes $H L A$ são fundamentais na resposta imune a agentes patogênicos exógenos, pois participam da apresentação de antígenos ao sistema imune (Abbas et al., 2008). Como já foi relatada, sua alta diversidade foi correlacionada com a diversidade de patógenos e diversos estudos apontam para o sinal de seleção natural do tipo balanceadora atuando na manutenção da diversidade genética desses genes (Prugnolle et al., 2005).

Portanto, é plausível considerar que a alteração da composição de antígenos, provocada pela chegada dos europeus portugueses e africanos, tenha imposto um regime de seleção intenso, associado aos eventos demográficos drásticos, e que, todos esses fatores tenham deixado algum sinal diferencial na região do MHC. 
Nossos resultados apontam para um desvio de ancestralidade na região do MHC o que sugere seleção contra alelos ameríndios e a favor dos europeus. Esse padrão difere daquele encontrado por Tang (2007), que observou um excesso de ancestralidade africana. Naquele caso, o argumento para o desvio foi de que populações africanas, por serem mais diversas, tinham maior probabilidade de carregar alelos vantajosos no novo contexto. Por outro lado, Johnson et al. (2011) mostram que o componente ancestral selecionado no HLA não é restrito ao africano, e a partir disso argumentam que a ancestralidade selecionada irá variar entre localidades. Nosso resultado reforça essa perspectiva, mostrando que para uma população tri-híbrida da Amazônia, a ancestralidade europeia é aquela que apresenta um aumento de frequência, em detrimento da indígena.

Por que motivos alelos europeus teriam sido vantajosos em populações miscigenadas da Amazônia? Como relatamos acima, uma explicação é a de que os alelos europeus eram justamente aqueles que carregavam variantes alélicas que haviam sido selecionadas para oferecer resistência às doenças infecciosas mais comuns na Europa (sarampo, varíola, gripe), e que vitimaram populações indígenas, causando taxas altíssimas de mortalidade. Consequentemente, indivíduos com genótipos europeus tinham uma aptidão maior do que indivíduos com genótipos ameríndios, dessa explicando o aumento dos alelos europeus.

\section{6- Discussão Geral e Conclusões}

Neste estudo investigamos a variação genética em genes de HLA classe II num conjunto de populações nativas da América do Sul, e em microssatélites localizados na 
região do MHC (onde os genes de HLA estão contidos) numa amostra urbana, vinda da cidade de Belém. Em ambos os casos nossa motivação consistia em caracterizar o papel de processos demográficos (deriva genética, migração, mudanças de tamanho efetivo populacional) e seletivos na geração da diversidade genética nos genes HLA nessas amostras.

Nós partimos da premissa de que os genes HLA sofreram seleção natural ao longo de sua história evolutiva, que explicam os diversos padrões de variação distintos daqueles esperados sob neutralidade, previamente documentados (Meyer e Thomson, 2001, Hughes \& Yeager, 1998). Entretanto, as evidência de seleção natural não são igualmente identificáveis para testes de neutralidade que são sensíveis aos efeitos de seleção natural em diferentes escalas de tempo.

Por exemplo, Garrigan e Hedrick (2003) mostraram que há fortes evidências de seleção em genes HLA usando testes baseados em comparações interespecíficas (que envolvem eventos que ocorreram ao longo de milhares de anos), menos evidências quando usamos métodos sensíveis a seleção que tenha atuado em escalas de tempo intermediárias (centenas ou dezenas de milhares de anos), e ausência de evidências de seleção quando testamos para seleção usando variação genética que só seria alterada por seleção atuando no passado muito próximo (ex., desvios de Hardy-Weinberg).

A interpretação para a variação no grau com o qual a seleção é documentado para essas diferentes escalas de tempo é difícil, uma vez que podem resultar tanto de mudanças na intensidade do regime de seleção natural ao longo do tempo, como do poder estatístico dos testes (sendo aqueles baseados em comparações envolvendo populações/espécies que divergiram a mais tempo) (R Nielsen, 2001). 
No presente estudo nós retomamos essas questões ao abordar o papel de processos demográficos e seletivos na geração de diversidade de genes de HLA. Nossa abordagem consistiu em utilizar marcadores presumivelmente neutros, não ligados aos genes HLA, para fornecerem um controle demográfico, em relação aos quais a variação em genes HLA (ou genes proximamente ligados) pode ser analisada.

A análise dos genes de HLA classe II em populações Ameríndias revelou que usando o teste sensível a eventos seletivos em maior profundidade temporal (D de Tajima), nosso poder para detectar seleção é aumentando e de fato observamos desvios de neutralidade na maior parte das populações.

Entretanto, pudemos documentar que para essas mesmas amostras, a história demográfica tem um importante papel em moldar o nível de variação desses genes intensamente selecionados, como pôde ser visto na significativa redução de diversidade (medida por He) das populações ameríndias, em relação a outras regiões do mundo.

Em conjunto, esse capítulo confirmou, no contexto das américas e para os genes de classe II, padrões anteriormente documentados em escala global (ex., Meyer et al., 2006), de que o fato dos genes HLA serem intensamente selecionados não impede que a história demográfica das populações tenham um forte efeito sobre eles. Além disso, pudemos demonstrar que testes de neutralidade que utilizam dados de sequência (como é o caso do D de Tajima) permitem inferências com maior poder, revelando padrões diferentes daqueles que seria obtidos por testes baseados apenas nas frequências alélicas.

Entretanto, este primeiro estudo não pôde estabelecer se o fato das evidências de neutralidade terem sido visíveis para os Ameríndios com o teste D de Tajima resulta do 
fato da seleção apenas atuar em escalas de tempo mais remotas (às quais o teste é sensível) ou se, mesmo com a seleção atuando intensamente em gerações recentes, apenas detecta-se seleção remota em função do poder reduzido do teste para eventos mais recentes (Garrigan \& Hedrick, 2003).

Para abordar essa questão realizamos a análise da região do MHC numa população miscigenada e urbana da região Amazônica. Nossa motivação foi a de que estudos baseados em miscigenação revelaram-se poderosos para detectar eventos de seleção natural recente, visíveis num desvios de ancestralidade na população miscigenada para a região do genoma que foi alvo de seleção (Tang et al., 2007; Winkler \& Smith, 2010). Esses testes tem poder estatístico elevado, mesmo para eventos de seleção temporalmente mais rasos, sendo portanto uma abordagem promissora no contexto de nossa questão geral, a respeito da interação entre demografia e seleção e escala de tempo da ação da seleção em genes HLA.

Nossa análise revelou um desvio de ancestralidade na região do MHC, usando duas abordagens (uma baseada em estimativas de ancestralidade usando o método implementado pelo STRUCTURE, e outra baseada no uso de FST como indicador do grau de partilhamento de alelos entre uma população miscigenada e suas parentais).

Em ambos os casos nossos resultados apontaram para um déficit de ancestralidade ameríndia em Belém para a região do MHC, em relação ao esperado com base nos valores de miscigenação inferidos por marcadores em outras regiões do genoma. Compensando essa perda de ancestralidade ameríndia no MHC, notamos um aumento da ancestralidade europeia. 
Nossos resultados são consistentes com um cenário em que a seleção natural favoreceu alelos Europeus nas populações miscigenadas, em detrimento dos ameríndios. Uma hipótese para esse padrão seria a forte pressão seletiva exercida por doenças infecciosas, às quais os ameríndios eram mais suscetíveis do que os europeus.

Em conjunto, nossos resultados mostram que tanto a seleção natural como a demografia moldaram a variação genética em genes HLA, e que usando métodos apropriados, incluindo o mapeamento por miscigenação, até mesmo eventos de seleção natural que ocorreram em escalas de tempo recentes podem ser detectados. 


\section{7 - Referências Bibliográficas}

Akey, J. M. (2009). Constructing genomic maps of positive selection in humans: where do we go from here? Genome research, 19(5), 711-22. doi:10.1101/gr.086652.108

Akey, J. M., Eberle, M. a, Rieder, M. J., Carlson, C. S., Shriver, M. D., Nickerson, D. a, \& Kruglyak, L. (2004). Population history and natural selection shape patterns of genetic variation in 132 genes. PLoS biology, 2(10), e286. doi:10.1371/journal.pbio.0020286

Akey, J. M., Zhang, G., Zhang, K., Jin, L., \& Shriver, M. D. (2002). Interrogating a high-density SNP map for signatures of natural selection. Genome research, 12(12), 1805-14. doi:10.1101/gr.631202

Apanius, V., Penn, D., Slev, P. R., Ruff, L. R., \& Potts, W. K. (1997). The nature of selection on the major histocompatibility complex. Critical reviews in immunology, 17(2), 179-224. Retrieved from http://www.ncbi.nlm.nih.gov/pubmed/9094452

Bamshad, M., \& Wooding, S. P. (2003). Signatures of natural selection in the human genome. Nature reviews. Genetics, 4(2), 99-111. doi: $10.1038 / \mathrm{nrg} 999$

Barreiro, L. B., Laval, G., Quach, H., Patin, E., \& Quintana-Murci, L. (2008). Natural selection has driven population differentiation in modern humans. Nature genetics, 40(3), 340-5. doi:10.1038/ng.78

Basu, A., Tang, H., Zhu, X., Gu, C. C., Hanis, C., Boerwinkle, E., \& Risch, N. (2008). Genome-wide distribution of ancestry in Mexican Americans. Human genetics, 124(3), 207-14. doi:10.1007/s00439008-0541-5

Batista dos Santos, S. E., Rodrigues, J. D., Ribeiro-dos-Santos, a K., \& Zago, M. a. (1999). Differential contribution of indigenous men and women to the formation of an urban population in the Amazon region as revealed by mtDNA and Y-DNA. American journal of physical anthropology, 109(2), 175-80. doi:10.1002/(SICI)10968644(199906)109:2<175::AID-AJPA3>3.0.CO;2-\#

Belich, M. P., Madrigal, J. A., Hildebrand, W. H., Zemmour, J., Williams, R. C., Luz, R., Petzl-Erler, M. L., et al. (1992). Unusual HLA-B alleles in two tribes of Brazilian Indians. Nature, 357(6376), 326-9. doi:10.1038/357326a0 
Boca, S. M., \& Rosenberg, N. A. (2011). Mathematical properties of Fst between admixed populations and their parental source populations. Theoretical population biology, 80(3), 208-16. doi:10.1016/j.tpb.2011.05.003

Bowcock, A. M., Ruiz-Linares, A., Tomfohrde, J., Minch, E., Kidd, J. R., \& Cavalli-Sforza, L. L. (1994). High resolution of human evolutionary trees with polymorphic microsatellites. Nature, 368(6470), 455-7. doi:10.1038/368455a0

Bustamante, C. D., Fledel-Alon, A., Williamson, S., Nielsen, R., Hubisz, M. T., Glanowski, S., Tanenbaum, D. M., et al. (2005). Natural selection on protein-coding genes in the human genome. Nature, 437(7062), 1153-7. doi:10.1038/nature04240

Cadavid, L. F., \& Watkins, D. I. (1997). Heirs of the jaguar and the anaconda: HLA, conquest and disease in the indigenous populations of the Americas. Tissue antigens, 50(6), 702-11. Retrieved from http://www.ncbi.nlm.nih.gov/pubmed/9458134

Clark, A. G., Glanowski, S., Nielsen, R., Thomas, P., Kejariwal, A., Todd, M. J., Tanenbaum, D. M., et al. (2003). Positive selection in the human genome inferred from human-chimp-mouse orthologous gene alignments. Cold Spring Harbor symposia on quantitative biology, 68, 471-7. Retrieved from http://www.ncbi.nlm.nih.gov/pubmed/15338650

Consortium, M. sequencing. (1999). Complete sequence and gene map of a human major histocompatibility complex. The MHC sequencing consortium. Nature, 401(6756), 921-3. doi:10.1038/44853

Coop, G., Bullaughey, K., Luca, F., \& Przeworski, M. (2008). The timing of selection at the human FOXP2 gene. Molecular biology and evolution, 25(7), 1257-9. doi:10.1093/molbev/msn091

De Meeûs, T., \& Goudet, J. (2007). A step-by-step tutorial to use HierFstat to analyse populations hierarchically structured at multiple levels. Infection, genetics and evolution: journal of molecular epidemiology and evolutionary genetics in infectious diseases, 7(6), 731-5. doi:10.1016/j.meegid.2007.07.005

Dixon, A. L., Liang, L., Moffatt, M. F., Chen, W., Heath, S., Wong, K. C. C., Taylor, J., et al. (2007). A genome-wide association study of global gene expression. Nature genetics, 39(10), 1202-7.

doi:10.1038/ng2109 
Epplen, C., Santos, E. J., Guerreiro, J. F., Van Helden, P., \& Epplen, J. T. (1997). Coding versus intron variability: extremely polymorphic HLADRB1 exons are flanked by specific composite microsatellites, even in distant populations. Human genetics, 99(3), 399-406. Retrieved from http://www.ncbi.nlm.nih.gov/pubmed/9050930

Excoffier, L., \& Heckel, G. (2006). Computer programs for population genetics data analysis: a survival guide. Nature reviews. Genetics, 7(10), 745-58. doi:10.1038/nrg 1904

Fumagalli, M., Sironi, M., Pozzoli, U., Ferrer-Admetlla, A., FerrerAdmettla, A., Pattini, L., \& Nielsen, R. (2011). Signatures of environmental genetic adaptation pinpoint pathogens as the main selective pressure through human evolution. PLoS genetics, 7(11), e1002355. doi:10.1371/journal.pgen.1002355

Fuselli, S., Tarazona-Santos, E., Dupanloup, I., Soto, A., Luiselli, D., \& Pettener, D. (2003). Mitochondrial DNA diversity in South America and the genetic history of Andean highlanders. Molecular biology and evolution, 20(10), 1682-91. doi:10.1093/molbev/msg188

Garrigan, D., \& Hedrick, P. W. (2003). Perspective: detecting adaptive molecular polymorphism: lessons from the MHC. Evolution; international journal of organic evolution, 57(8), 1707-22. Retrieved from http://www.ncbi.nlm.nih.gov/pubmed/14503614

Guo, S. W., \& Thompson, E. A. (1992). A Monte Carlo method for combined segregation and linkage analysis. American journal of human genetics, 51(5), 1111-26. Retrieved from http://www.pubmedcentral.nih.gov/articlerender.fcgi?artid=1682838\& tool=pmcentrez\&rendertype $=$ abstract

Hedrick, P. W., \& Thomson, G. (1983). Evidence for balancing selection at HLA. Genetics, 104(3), 449-56. Retrieved from http://www.pubmedcentral.nih.gov/articlerender.fcgi?artid=1202087\& tool=pmcentrez\&rendertype $=$ abstract

Helmberg, W., Dunivin, R., \& Feolo, M. (2004). The sequencing-based typing tool of dbMHC: typing highly polymorphic gene sequences. Nucleic acids research, 32(Web Server issue), W173-5. doi:10.1093/nar/gkh424

Hey, J. (2005). On the number of New World founders: a population genetic portrait of the peopling of the Americas. PLoS biology, 3(6), e193. doi:10.1371/journal.pbio.0030193 
Hofer, T., Foll, M., \& Excoffier, L. (2012). Evolutionary forces shaping genomic islands of population differentiation in humans. $B M C$ genomics, 13(1), 107. doi:10.1186/1471-2164-13-107

Holcomb, C. L., Höglund, B., Anderson, M. W., Blake, L. a, Böhme, I., Egholm, M., Ferriola, D., et al. (2011). A multi-site study using highresolution HLA genotyping by next generation sequencing. Tissue antigens, 77(3), 206-17. doi:10.1111/j.1399-0039.2010.01606.x

Hughes, A L, \& Yeager, M. (1998). Natural selection at major histocompatibility complex loci of vertebrates. Annual review of genetics, 32, 415-35. doi:10.1146/annurev.genet.32.1.415

Hughes, Austin L, Packer, B., Welch, R., Chanock, S. J., \& Yeager, M. (2005). High level of functional polymorphism indicates a unique role of natural selection at human immune system loci. Methods, 821-827. doi:10.1007/s00251-005-0052-7

Hughes, A L \& Nei, M. (1988). Pattern of nucleotide substitution at major histocompatibility complex class I loci reveals overdominant selection. Nature.

Hünemeier, T., Carvalho, C., Marrero, A. R., Salzano, F. M., Junho Pena, S. D., \& Bortolini, M. C. (2007). Niger-Congo speaking populations and the formation of the Brazilian gene pool: mtDNA and Ychromosome data. American journal of physical anthropology, 133(2), 854-67. doi:10.1002/ajpa.20604

Johnson, N. a., Coram, M. a., Shriver, M. D., Romieu, I., Barsh, G. S., London, S. J., \& Tang, H. (2011). Ancestral Components of Admixed Genomes in a Mexican Cohort. (G. P. Copenhaver, Ed.)PLoS Genetics, 7(12), e1002410. doi:10.1371/journal.pgen.1002410

Kitchen, A., Miyamoto, M. M., \& Mulligan, C. J. (2008). A three-stage colonization model for the peopling of the Americas. PloS one, 3(2), e1596. doi:10.1371/journal.pone.0001596

Kostyu, D. D., \& Amos, D. B. (1981). Mysteries of the Amerindians. Tissue antigens, 17(1), 111-23. Retrieved from http://www.ncbi.nlm.nih.gov/pubmed/7245181

Lewontin, R. C., \& Krakauer, J. (1973). Distribution of gene frequency as a test of the theory of the selective neutrality of polymorphisms. Genetics, 74(1), 175-95. Retrieved from http://www.pubmedcentral.nih.gov/articlerender.fcgi?artid=1212935\& tool $=$ pmcentrez\&rendertype $=$ abstract 
Livshits, G., \& Nei, M. (n.d.). Relationships between intrapopulational and interpopulational genetic diversity in man. Annals of human biology, 17(6), 501-13. Retrieved from http://www.ncbi.nlm.nih.gov/pubmed/2281941

Long, J. C. (1991). The genetic structure of admixed populations. Genetics, 127(2), 417-28. Retrieved from http://www.pubmedcentral.nih.gov/articlerender.fcgi?artid=1204369\& tool=pmcentrez\&rendertype $=$ abstract

Marsh, S. G. E. (2013). Nomenclature for factors of the HLA system, update December 2012. Tissue antigens, 81(4), 253-7. doi:10.1111/tan.12077

Meyer, D, \& Thomson, G. (2001). How selection shapes variation of the human major histocompatibility complex: a review. Annals of human genetics, 65(Pt 1), 1-26. Retrieved from http://www.ncbi.nlm.nih.gov/pubmed/11415519

Meyer, Diogo, Single, R. M., Mack, S. J., Erlich, H. a, \& Thomson, G. (2006). Signatures of demographic history and natural selection in the human major histocompatibility complex Loci. Genetics, 173(4), 2121-42. doi:10.1534/genetics.105.052837

Nielsen, R. (2001). Statistical tests of selective neutrality in the age of genomics. Heredity, 86(Pt 6), 641-7. Retrieved from http://www.ncbi.nlm.nih.gov/pubmed/11595044

Nielsen, Rasmus, Hubisz, M. J., Hellmann, I., Torgerson, D., Albrechtsen, A., Gutenkunst, R., Adams, M. D., et al. (2009). Darwinian and demographic forces affecting human protein coding genes. Genome Research, 838-849. doi:10.1101/gr.088336.108.838

Nielsen, Rasmus, Williamson, S., Kim, Y., Hubisz, M. J., Clark, A. G., \& Bustamante, C. (2005). Genomic scans for selective sweeps using SNP data. Genome research, 15(11), 1566-75. doi:10.1101/gr.4252305

Parham, P., Arnett, K. L., Adams, E. J., Little, a M., Tees, K., Barber, L. D., Marsh, S. G., et al. (1997). Episodic evolution and turnover of HLA-B in the indigenous human populations of the Americas. Tissue antigens, 50(3), 219-32. Retrieved from http://www.ncbi.nlm.nih.gov/pubmed/9331945

Pedroza, L. S. R. A., Sauma, M. F. L. C., Vasconcelos, J. M., Takeshita, L. Y. C., Ribeiro-Rodrigues, E. M., Sastre, D., Barbosa, C. M., et al. (2011). Systemic lupus erythematosus: association with KIR and 
SLC11A1 polymorphisms, ethnic predisposition and influence in clinical manifestations at onset revealed by ancestry genetic markers in an urban Brazilian population. Lupus, 20(3), 265-73. doi:10.1177/0961203310385266

Pérez-Lezaun, A., Calafell, F., Mateu, E., Comas, D., Ruiz-Pacheco, R., \& Bertranpetit, J. (1997). Microsatellite variation and the differentiation of modern humans. Human genetics, 99(1), 1-7. Retrieved from http://www.ncbi.nlm.nih.gov/pubmed/9003483

Pritchard, J. K., Stephens, M., \& Donnelly, P. (2000). Inference of population structure using multilocus genotype data. Genetics, 155(2), 945-59. Retrieved from http://www.pubmedcentral.nih.gov/articlerender.fcgi?artid=1461096\& tool=pmcentrez\&rendertype $=$ abstract

Prugnolle, F., Manica, A., \& Balloux, F. (2005). Geography predicts neutral genetic diversity of human populations. Current biology: $C B$, 15(5), R159-60. doi:10.1016/j.cub.2005.02.038

Rosenberg, N. A., Mahajan, S., Ramachandran, S., Zhao, C., Pritchard, J. K., \& Feldman, M. W. (2005). Clines, clusters, and the effect of study design on the inference of human population structure. PLoS genetics, 1(6), e70. doi:10.1371/journal.pgen.0010070

Sabeti, P C, Schaffner, S. F., Fry, B., Lohmueller, J., Varilly, P., Shamovsky, O., Palma, A., et al. (2006). Positive natural selection in the human lineage. Science (New York, N.Y.), 312(5780), 1614-20. doi:10.1126/science.1124309

Sabeti, Pardis C, Reich, D. E., Higgins, J. M., Levine, H. Z. P., Richter, D. J., Schaffner, S. F., Gabriel, S. B., et al. (2002). Detecting recent positive selection in the human genome from haplotype structure. October, 419(October). doi:10.1038/nature01027.1.

Salzano, F. M. (2002). Molecular variability in Amerindians: widespread but uneven information. Anais da Academia Brasileira de Ciências, 74(2), 223-63. Retrieved from http://www.ncbi.nlm.nih.gov/pubmed/12098752

Sanchez-Mazas, A., Lemaître, J.-F., \& Currat, M. (2012). Distinct evolutionary strategies of human leucocyte antigen loci in pathogenrich environments. Philosophical transactions of the Royal Society of London. Series B, Biological sciences, 367(1590), 830-9. doi:10.1098/rstb.2011.0312 
Santos, N. P. C., Ribeiro-Rodrigues, E. M., Ribeiro-Dos-Santos, A. K. C., Pereira, R., Gusmão, L., Amorim, A., Guerreiro, J. F., et al. (2010). Assessing individual interethnic admixture and population substructure using a 48-insertion-deletion (INSEL) ancestryinformative marker (AIM) panel. Human mutation, 31(2), 184-90. doi:10.1002/humu.21159

Sayer, D., Whidborne, R., Brestovac, B., Trimboli, F., Witt, C., \& Christiansen, F. (2001). HLA-DRB1 DNA sequencing based typing: an approach suitable for high throughput typing including unrelated bone marrow registry donors. Tissue Antigens, 46-54.

Schroeder, K. B., Jakobsson, M., Crawford, M. H., Schurr, T. G., Boca, S. M., Conrad, D. F., Tito, R. Y., et al. (2009). Haplotypic background of a private allele at high frequency in the Americas. Molecular biology and evolution, 26(5), 995-1016. doi:10.1093/molbev/msp024

Solberg, O. D., Mack, S. J., Lancaster, A. K., Single, R. M., Tsai, Y., Sanchez-mazas, A., \& Thomson, G. (2008). Balancing selection and heterogeneity across the classical human leukocyte antigen loci : A meta-analytic review of 497 population studies. Molecular Biology, 443-464. doi:10.1016/j.humimm.2008.05.001

Stajich, J. E., \& Hahn, M. W. (2005). Disentangling the effects of demography and selection in human history. Molecular biology and evolution, 22(1), 63-73. doi:10.1093/molbev/msh252

Tang, H., Choudhry, S., Mei, R., Morgan, M., Rodriguez-Cintron, W., Burchard, E. G., \& Risch, N. J. (2007). Recent genetic selection in the ancestral admixture of Puerto Ricans. American journal of human genetics, 81(3), 626-33. doi:10.1086/520769

Tarazona-Santos, E., Carvalho-Silva, D. R., Pettener, D., Luiselli, D., De Stefano, G. F., Labarga, C. M., Rickards, O., et al. (2001). Genetic differentiation in South Amerindians is related to environmental and cultural diversity: evidence from the Y chromosome. American journal of human genetics, 68(6), 1485-96. doi:10.1086/320601

Tsuneto, L. T., Probst, C. M., Hutz, M. H., Salzano, F. M., RodriguezDelfin, L. a, Zago, M. a, Hill, K., et al. (2003). HLA class II diversity in seven Amerindian populations. Clues about the origins of the Aché. Tissue antigens, 62(6), 512-26. Retrieved from http://www.ncbi.nlm.nih.gov/pubmed/14617035 
Varney, M. D., Gavrilidis, a, \& Tait, B. D. (1999). Polymorphism in the regulatory regions of the HLA-DPB1 gene. Human immunology, 60(10), 955-61. Retrieved from http://www.ncbi.nlm.nih.gov/pubmed/10566595

Villadangos, J. a, \& Schnorrer, P. (2007). Intrinsic and cooperative antigen-presenting functions of dendritic-cell subsets in vivo. Nature reviews. Immunology, 7(7), 543-55. doi:10.1038/nri2103

Voight, B. F., Kudaravalli, S., Wen, X., \& Pritchard, J. K. (2006). A map of recent positive selection in the human genome. PLoS biology, 4(3), e72. doi:10.1371/journal.pbio.0040072

Wang, S., Lewis, C. M., Jakobsson, M., Ramachandran, S., Ray, N., Bedoya, G., Rojas, W., et al. (2007). Genetic variation and population structure in native Americans. PLoS genetics, 3(11), e185. doi:10.1371/journal.pgen.0030185

Watkins, D. I., McAdam, S. N., Liu, X., Strang, C. R., Milford, E. L., Levine, C. G., Garber, T. L., et al. (1992). New recombinant HLA-B alleles in a tribe of South American Amerindians indicate rapid evolution of MHC class I loci. Nature, 357(6376), 329-33. doi:10.1038/357329a0

Watts, C. (1997). Capture and processing of exogenous antigens for presentation on MHC molecules. Annual review of immunology, 15, 821-50. doi:10.1146/annurev.immunol.15.1.821

Winkler, C. a, Nelson, G. W., \& Smith, M. W. (2010). Admixture mapping comes of age. Annual review of genomics and human genetics, 11, 6589. doi:10.1146/annurev-genom-082509-141523

Yang, K., Zheng, H., Qin, Z., Lu, Y., Farina, S. E., Li, S., Jin, L., et al. (2011). Positive selection on mitochondrial M7 lineages among the Gelong people in Hainan. Journal of human genetics, 56(3), 253-6. doi:10.1038/jhg.2010.165

Zhivotovsky, L. A., Rosenberg, N. A., \& Feldman, M. W. (2003). Features of evolution and expansion of modern humans, inferred from genomewide microsatellite markers. American journal of human genetics, 72(5), 1171-86. doi:10.1086/375120 


\section{Apêndice}

Tabela 1A- Lista dos alelos que foram substituídos por um alelo genérico.

\begin{tabular}{|c|c|c|c|c|c|}
\hline & $H L A-D R B 1$ & & $H L A-D Q B 1$ & & $H L A-D P B 1$ \\
\hline $\begin{array}{c}\text { Alelos } \\
\text { Genéricos }\end{array}$ & $\begin{array}{l}\text { Alelos encontrados } \\
\text { no banco de dados }\end{array}$ & $\begin{array}{c}\text { Alelos } \\
\text { Genéricos }\end{array}$ & $\begin{array}{l}\text { Alelos encontrados } \\
\text { no banco de dados }\end{array}$ & $\begin{array}{c}\text { Alelos } \\
\text { Genéricos }\end{array}$ & $\begin{array}{c}\text { Alelos } \\
\text { encontrados no } \\
\text { banco de dados } \\
\end{array}$ \\
\hline$D R B 1 * 01: 01$ & $D R B 1 * 01: 01: 01$ & $D Q B 1 * 03: 01$ & $\begin{array}{l}D Q B 1 * 03: 01: 01, \\
D Q B 1 * 03: 01: 01: 01 \\
D Q B 1 * 03: 01: 02\end{array}$ & $D P B 1 * 01: 01$ & $\begin{array}{l}D P B 1 * 01: 01: 01 \\
D P B 1 * 01: 01: 02\end{array}$ \\
\hline$D R B 1 * 01: 02$ & $D R B 1 * 01: 02: 01$ & $D Q B 1 * 03: 02$ & $\begin{array}{l}D Q B 1 * 03: 02: 01 \\
D Q B 1 * 03: 02: 03\end{array}$ & $D P B 1 * 02: 01$ & $D P B 1 * 02: 01: 02$ \\
\hline$D R B 1 * 03: 01$ & $\begin{array}{l}D R B 1 * 03: 01: 01 \\
D R B 1 * 03: 01: 01: 01\end{array}$ & $D Q B 1 * 03: 03$ & $\begin{array}{l}D Q B 1 * 03: 03: 02, \\
D Q B 1 * 03: 03: 02: 01 \\
D Q B 1 * 03: 03: 03\end{array}$ & $D P B 1 * 03: 01$ & $D P B 1 * 03: 01: 01$ \\
\hline$D R B 1 * 03: 02$ & $\begin{array}{l}D R B 1 * 03: 02: 01 \\
D R B 1 * 03: 02: 02\end{array}$ & $D Q B 1 * 04: 01$ & $\begin{array}{l}D Q B 1 * 04: 01: 02 \\
D Q B 1 * 04: 01: 01\end{array}$ & $D P B 1 * 04: 01$ & $D P B 1 * 04: 01: 01$ \\
\hline$D R B 1 * 04: 01$ & $D R B 1 * 04: 01: 01$ & $D Q B 1 * 05: 01$ & $D Q B 1 * 05: 01: 01: 01$ & $D P B 1 * 04: 02:$ & $\begin{array}{l}D P B 1 * 04: 02: 01: \\
01\end{array}$ \\
\hline$D R B 1 * 04: 02$ & $D R B 1 * 04: 02: 01$ & $D Q B 1 * 05: 03$ & $\begin{array}{l}D Q B 1 * 05: 03: 01: 01 \\
D Q B 1 * 05: 03: 02\end{array}$ & $D P B 1 * 11: 01$ & $\begin{array}{l}D P B 1 * 11: 01: 01, \\
D P B 1 * 11: 01: 02\end{array}$ \\
\hline$D R B 1 * 04: 03$ & $D R B 1 * 04: 03: 01$ & $D Q B 1 * 06: 01$ & $\begin{array}{l}D Q B 1 * 06: 01: 01, \\
D Q B 1 * 06: 01: 02\end{array}$ & $D P B 1 * 20: 01$ & $D P B 1 * 20: 01: 01$ \\
\hline$D R B 1 * 04: 04$ & $D R B 1 * 04: 04: 05$ & $D Q B 1 * 06: 04$ & $D Q B 1 * 06: 04: 01$ & & \\
\hline$D R B 1 * 04: 05$ & $\begin{array}{l}D R B 1 * 04: 05: 01 \\
D R B 1 * 04: 05: 04\end{array}$ & $D Q B 1 * 06: 05$ & $\begin{array}{l}D Q B 1 * 06: 05: 01 \\
D Q B 1 * 06: 05: 02\end{array}$ & & \\
\hline$D R B 1 * 04: 07$ & $\begin{array}{l}D R B 1 * 04: 07: 01 \\
D R B 1 * 04: 07: 03\end{array}$ & $D Q B 1 * 06: 11$ & $D Q B 1 * 06: 11: 01$ & & \\
\hline$D R B 1 * 04: 10$ & $D R B 1 * 04: 10: 01$ & & & & | \\
\hline$D R B 1 * 04: 11$ & $D R B 1 * 04: 11: 01$ & & & & \\
\hline$D R B 1 * 07: 01$ & $\begin{array}{l}\text { DRB1 *07:01:01, } \\
\text { DRB1*07:01:01:01 }\end{array}$ & & & & \\
\hline$D R B 1 * 08: 01$ & DRB1 *08:01:01 & & & & \\
\hline$D R B 1 * 08: 02$ & $D R B 1 * 08: 02: 01$ & & & & \\
\hline$D R B 1 * 08: 04$ & $D R B 1 * 08: 04: 01$ & & & & \\
\hline$D R B 1 * 09: 01$ & $D R B 1 * 09: 01: 02$ & & & & \\
\hline$D R B 1 * 10: 01$ & $D R B 1 * 10: 01: 01$ & & & & \\
\hline$D R B 1 * 11: 01$ & $\begin{array}{l}D R B 1 * 11: 01: 01 \\
D R B 1 * 11: 01: 02\end{array}$ & & & & \\
\hline$D R B 1 * 11: 02$ & $D R B 1 * 11: 02: 01$ & & & & \\
\hline$D R B 1 * 11: 04$ & $D R B 1 * 11: 04: 01$ & & & & \\
\hline$D R B 1 * 12: 01$ & $D R B 1 * 12: 01: 01$ & & & & \\
\hline$D R B 1 * 12: 02$ & $D R B 1 * 12: 02: 01$ & & & & \\
\hline$D R B 1 * 13: 01$ & $D R B 1 * 13: 01: 01$ & & & & \\
\hline$D R B 1 * 13: 02$ & $D R B 1 * 13: 02: 01$ & & & & \\
\hline$D R B 1 * 13: 03$ & $\begin{array}{l}D R B 1 * 13: 03: 01, \\
D R B 1 * 13: 03: 02\end{array}$ & & & & \\
\hline$D R B 1 * 13: 05$ & $D R B 1 * 13: 05: 01$ & & & & \\
\hline$D R B 1 * 14: 01$ & $D R B 1 * 14: 01: 01$ & & & & \\
\hline$D R B 1 * 14: 03$ & $D R B 1 * 14: 03: 01$ & & & & \\
\hline$D R B 1 * 14: 06$ & $D R B 1 * 14: 06: 01$ & & & & \\
\hline$D R B 1 * 15: 01$ & $\begin{array}{l}D R B 1 * 15: 01: 01 \\
D R B 1 * 15: 01: 01: 01\end{array}$ & & & & \\
\hline$D R B 1 * 15: 02$ & $D R B 1 * 15: 02: 01$ & & & & \\
\hline$D R B 1 * 16: 01$ & $D R B 1 * 16: 01: 01$ & & & & \\
\hline$D R B 1 * 16: 02$ & $D R B 1 * 16: 02: 01$ & & & & \\
\hline
\end{tabular}


Tabela 2A. Estimativas de Hardy-Weinberg para os genes HLA-DRB1, HLA$D Q B 1, H L A-D R B 1$ nas populações nativas da América. Onde $\mathrm{HO}=$ Heterozigose observada; $\mathrm{HE}=$ Heterozigose esperada; $\mathrm{p}=\mathrm{p}=$ =valor; $\mathrm{p}$-cor= $\mathrm{p}$-valor corrigida para múltiplos testes.

\begin{tabular}{|c|c|c|c|c|c|c|c|c|c|}
\hline \multirow[b]{2}{*}{ População } & \multicolumn{2}{|c|}{ HLA - DRB1 } & \multirow[b]{2}{*}{$\begin{array}{l}p- \\
\text { valor }\end{array}$} & \multicolumn{3}{|c|}{ HLA-DQB1 } & \multicolumn{3}{|c|}{ HLA-DRB1 } \\
\hline & Ho & $\mathrm{He}$ & & Ho & $\mathrm{He}$ & $\begin{array}{l}p- \\
\text { valor }\end{array}$ & Ho & $\mathrm{He}$ & p-valor \\
\hline & 1,00 & 0,90 & & & & & & & \\
\hline \multirow[t]{2}{*}{ Tundra_Nentsi } & 0 & 7 & 0,989 & $* * * *$ & $* * * *$ & $* * * *$ & $* * * *$ & $* * * *$ & $* * * *$ \\
\hline & 1,00 & 0,89 & & & & & & & \\
\hline \multirow[t]{2}{*}{ Ojibwa } & 0 & 1 & 0,983 & $* * * *$ & $* * * *$ & $* * * *$ & $* * * *$ & $* * * *$ & $* * * *$ \\
\hline & 0,96 & 0,90 & & & & & & & \\
\hline \multirow[t]{2}{*}{ Chipewyan } & 0 & 9 & 0,328 & $* * * *$ & $* * * *$ & $* * * *$ & $* * * *$ & $* * * *$ & $* * * *$ \\
\hline & 0,88 & 0,92 & & & & & & & \\
\hline \multirow[t]{2}{*}{ Cree } & 9 & 9 & 0,235 & $* * * *$ & $* * * *$ & $* * * *$ & $* * * *$ & $* * * *$ & $* * * *$ \\
\hline & 0,80 & 0,80 & & & & & & & \\
\hline \multirow[t]{2}{*}{ Mixe } & 0 & 3 & 0,229 & $* * * *$ & $* * * *$ & $* * * *$ & $* * * *$ & $* * * *$ & $* * * *$ \\
\hline & 0,75 & 0,78 & & & & & & & \\
\hline \multirow[t]{2}{*}{ Mixtec } & 0 & 5 & 0,684 & $* * * *$ & $* * * *$ & $* * * *$ & $* * * *$ & $* * * *$ & $* * * *$ \\
\hline & 1,00 & 0,90 & & & & & & & \\
\hline \multirow[t]{2}{*}{ Zapotec } & 0 & 3 & 0,637 & $* * * *$ & $* * * *$ & $* * * *$ & $* * * *$ & $* * * *$ & $* * * *$ \\
\hline & 0,94 & 0,90 & & & & & & & \\
\hline \multirow[t]{2}{*}{ Kaqchikel } & 7 & 5 & 0,964 & $* * * *$ & $* * * *$ & $* * * *$ & $* * * *$ & $* * * *$ & $* * * *$ \\
\hline & 0,80 & 0,75 & & & & & & & \\
\hline \multirow[t]{2}{*}{ Cabecar } & 0 & 5 & 0,832 & $* * * *$ & $* * * *$ & $* * * *$ & $* * * *$ & $* * * *$ & $* * * *$ \\
\hline & 0,84 & 0,69 & & & & & & & \\
\hline \multirow[t]{2}{*}{ Guaymi } & 6 & 2 & 0,799 & $* * * *$ & $* * * *$ & $* * * *$ & $* * * *$ & $* * * *$ & $* * * *$ \\
\hline & 0,85 & 0,76 & & & & & & & \\
\hline \multirow[t]{2}{*}{ Embera } & 7 & 5 & 0,522 & $* * * *$ & $* * * *$ & $* * * *$ & $* * * *$ & $* * * *$ & $* * * *$ \\
\hline & 0,65 & 0,70 & & & & & & & \\
\hline \multirow[t]{2}{*}{ Waunana } & 0 & 9 & 0,004 & $* * * *$ & $* * * *$ & $* * * *$ & $* * * *$ & $* * * *$ & $* * * *$ \\
\hline & 0,58 & 0,60 & & & & & & & \\
\hline \multirow[t]{2}{*}{ Zenu } & 3 & 5 & 0,473 & $* * * *$ & $* * * *$ & $* * * *$ & $* * * *$ & $* * * *$ & $* * * *$ \\
\hline & 0,92 & 0,70 & & & & & & & \\
\hline \multirow[t]{2}{*}{ Kogi } & 9 & 9 & 0,060 & $* * * *$ & $* * * *$ & $* * * *$ & $* * * *$ & $* * * *$ & $* * * *$ \\
\hline & 0,82 & 0,76 & & & & & & & \\
\hline \multirow[t]{2}{*}{ Arhuaco } & 4 & 5 & 0,089 & $* * * *$ & $* * * *$ & $* * * *$ & $* * * *$ & $* * * *$ & $* * * *$ \\
\hline & 1,00 & 0,90 & & & & & & & \\
\hline \multirow[t]{2}{*}{ Wayuu } & 0 & 3 & 0,987 & $* * * *$ & $* * * *$ & $* * * *$ & $* * * *$ & $* * * *$ & $* * * *$ \\
\hline & 0,86 & 0,88 & & & & & & & \\
\hline \multirow[t]{2}{*}{ Inga } & 7 & 3 & 0,601 & $* * * *$ & $* * * *$ & $* * * *$ & $* * * *$ & $* * * *$ & $* * * *$ \\
\hline & 0,71 & 0,73 & & & & & & & \\
\hline \multirow[t]{2}{*}{ Ticuna_Arara } & 4 & 3 & 0,617 & $* * * *$ & $* * * *$ & $* * * *$ & $* * * *$ & $* * * *$ & $* * * *$ \\
\hline & 0,63 & 0,61 & & & & & & & \\
\hline Ticuna_Tarapaca & 2 & 7 & 0,217 & $* * * *$ & $* * * *$ & $* * * *$ & $* * * *$ & $* * * *$ & $* * * *$ \\
\hline & 0,85 & 0,85 & & & & & & & \\
\hline Quechua & 7 & 3 & 0,292 & $* * * *$ & $* * * *$ & $* * * *$ & $* * * *$ & $* * * *$ & $* * * *$ \\
\hline
\end{tabular}




\begin{tabular}{|c|c|c|c|c|c|c|c|c|c|}
\hline & 0,70 & 0,79 & & & & & & & \\
\hline \multirow[t]{2}{*}{ Aymara } & 0 & 5 & 0,354 & $* * * *$ & $* * * *$ & $* * * *$ & $* * * *$ & $* * * *$ & $* * * *$ \\
\hline & 0,80 & 0,86 & & & & & & & \\
\hline \multirow[t]{2}{*}{ Huilliche } & 0 & 9 & 0,592 & $* * * *$ & $* * * *$ & $* * * *$ & $* * * *$ & $* * * *$ & $* * * *$ \\
\hline & 0,61 & 0,65 & & 0,69 & 0,66 & & 0,46 & 0,74 & \\
\hline \multirow[t]{2}{*}{ Tiriyo } & 5 & 8 & 0,199 & 2 & 8 & 0,230 & 2 & 2 & 0,101 \\
\hline & 0,75 & 0,80 & & & & & & & \\
\hline \multirow[t]{2}{*}{ Zoe } & 0 & 8 & 1,000 & $* * * *$ & $* * * *$ & $* * * *$ & $* * * *$ & $* * * *$ & $* * * *$ \\
\hline & & & & 0,47 & 0,59 & & 0,60 & 0,69 & \\
\hline \multirow[t]{2}{*}{ Arara } & $* * * *$ & $* * * *$ & $* * * *$ & 4 & 4 & 0,139 & 7 & 4 & 0,287 \\
\hline & 0,46 & 0,48 & & 0,52 & 0,48 & & 0,33 & 0,62 & \\
\hline \multirow[t]{2}{*}{ Arara_do_Iriri } & 7 & 0 & 1,000 & 9 & 7 & 1,000 & 3 & 0 & 0,114 \\
\hline & 0,53 & 0,79 & & 0,58 & 0,55 & & 0,62 & 0,74 & \\
\hline \multirow[t]{2}{*}{ Arara_do_Laranjal } & 3 & 1 & 0,003 & 3 & 4 & 0,452 & 5 & 2 & 0,429 \\
\hline & 0,72 & 0,75 & & 0,70 & 0,64 & & 0,18 & 0,60 & \\
\hline \multirow[t]{2}{*}{ Assurini } & 7 & 7 & 0,337 & 0 & 5 & 0,726 & 2 & 6 & 0,001 \\
\hline & 0,74 & 0,68 & & 0,73 & 0,66 & & 1,00 & 0,85 & \\
\hline \multirow[t]{2}{*}{ Arawete } & 1 & 3 & 0,280 & 1 & 3 & 0,204 & 0 & 7 & 0,660 \\
\hline & 0,75 & 0,84 & & 0,71 & 0,69 & & & & \\
\hline \multirow[t]{2}{*}{ Bakaja_Xikrin } & 0 & 8 & 0,368 & 4 & 0 & 0,759 & $* * * *$ & $* * * *$ & $* * * *$ \\
\hline & 0,75 & 0,80 & & 0,55 & 0,68 & & 0,00 & 0,80 & \\
\hline Kayapo_Xikrin & 0 & 0 & 0,478 & 6 & 0 & 0,421 & 0 & 0 & 0,003 \\
\hline Kayapo_Kokaimor & 0,75 & 0,63 & & 0,71 & 0,53 & & 0,11 & 0,29 & \\
\hline \multirow[t]{2}{*}{0} & 0 & 1 & 0,734 & 4 & 2 & 0,384 & 1 & 4 & 0,176 \\
\hline & 0,90 & 0,77 & & 0,80 & 0,68 & & 0,20 & 0,20 & \\
\hline \multirow[t]{2}{*}{ Parakana } & 9 & 5 & 0,980 & 0 & 3 & 0,600 & 0 & 0 & 1,000 \\
\hline & 0,59 & 0,64 & & 0,31 & 0,37 & & & & \\
\hline \multirow[t]{2}{*}{ Urubu_Kaapor } & 1 & 1 & 0,768 & 3 & 5 & 0,567 & $* * * *$ & $* * * *$ & $* * * *$ \\
\hline & 0,33 & 0,30 & & & & & 0,12 & 0,65 & \\
\hline \multirow[t]{2}{*}{ Ache } & 3 & 8 & 1,000 & $* * * *$ & $* * * *$ & $* * * *$ & 5 & 8 & 0,001 \\
\hline & 0,88 & 0,89 & & 0,65 & 0,62 & & & & \\
\hline \multirow[t]{2}{*}{ Guaranai_Kaiowa } & 9 & 0 & 0,085 & 3 & 1 & 0,112 & $* * * *$ & $* * * *$ & $* * * *$ \\
\hline & 0,61 & 0,76 & & 0,50 & 0,69 & & & & \\
\hline \multirow[t]{2}{*}{ Guarani_Mbya } & 5 & 3 & 0,149 & 0 & 2 & 0,703 & $* * * *$ & $* * * *$ & $* * * *$ \\
\hline & 0,60 & 0,72 & & 0,80 & 0,73 & & & & \\
\hline Kaingang & 0 & 2 & 0,036 & 0 & 3 & 0,200 & $* * * *$ & $* * * *$ & $* * * *$ \\
\hline
\end{tabular}


Tabela 3A. Estimativas de Hardy-Weinberg para os loci de microssatélites genômicos para as populações Africana, Europeia, Amerínida e de Belém. Onde $\mathrm{HO}=$ Heterozigose observada; $\mathrm{HE}=$ Heterozigose esperada; $\mathbf{p}=\mathbf{p}=\mathbf{v a l o r}$; $\mathbf{p}$-cor= $\mathbf{p}$-valor corrigida para múltiplos testes.

\begin{tabular}{|c|c|c|c|c|c|c|c|c|c|c|c|c|c|c|c|c|}
\hline \multirow[b]{2}{*}{ Locus } & \multicolumn{4}{|c|}{ Africanos } & \multicolumn{4}{|c|}{ Europeus } & \multicolumn{4}{|c|}{ Ameríndio } & \multicolumn{4}{|c|}{ Belém } \\
\hline & $\mathrm{HO}$ & $\mathrm{HE}$ & $\mathrm{P}$ & p-cor & $\mathrm{HO}$ & $\mathrm{HE}$ & $p$ & $p$-cor & $\mathrm{HO}$ & $\mathrm{HE}$ & $\mathrm{p}$ & $p$-cor & $\mathrm{HO}$ & $\mathrm{HE}$ & $p$ & $p$-cor \\
\hline D1S551 & 0,40 & 0,75 & 0,00 & 0,13 & 0,80 & 0,70 & 0,59 & 31,95 & 0,53 & 0,56 & 0,18 & 9,93 & 0,63 & 0,67 & 0,21 & 11,37 \\
\hline NAD1S_3 & 0,47 & 0,80 & 0,01 & 0,78 & 0,74 & 0,76 & 0,01 & 29 & 0,72 & 0,81 & 0,00 & 01 & 0,76 & 0,76 & 0,25 &, 46 \\
\hline D1S1660 & 0,77 & 0,78 & 0,94 & 50,63 & 0,76 & 0,74 & 0,16 & 8,55 & 0,61 & 0,72 & 0,00 & 0,04 & 0,80 & 0,79 & 0,98 & 52,66 \\
\hline GAT & & & & & & & & & & & & & & & & \\
\hline G & 0,87 & 0,74 & 0,76 & 40,98 & 0,57 & 0,70 & 0,44 & 23,49 & 0,63 & 0,67 & 0,38 & 20,46 & 0,69 & 0,70 & 0,78 & 42,29 \\
\hline D2S1328 & 0,80 & 0,83 & 0,19 & 10,02 & 0,75 & 0,73 & 0,48 & 26,00 & 0,78 & 0,80 & 0,25 & 13,47 & 0,78 & 0,77 & 0,26 & 14,22 \\
\hline D2S1391 & 0,67 & 0,76 & 0,62 & 33,44 & 0,62 & 0,79 & 0,08 & 4,51 & 0,56 & 0,57 & 0,47 & 25,60 & 0,70 & 0,71 & 0,31 & 16,81 \\
\hline $\mathrm{D} 2 \mathrm{~S}$ & 0,53 & 0,66 & 0,83 & 44,75 & 0,62 & 0,62 & 0,54 & 29,36 & 0,26 & 0,28 & 0,02 & 0,87 & 0,46 & 0,59 & 0,00 & 0,00 \\
\hline GATA146B & 0,57 & 0,60 & 0,26 & 13,94 & 0,60 & 0,69 & 0,77 & 41,59 & 0,67 & 0,59 & 0,04 & 2,34 & 0,62 & 0,62 & 0,95 & 51,27 \\
\hline D3S: & 0,45 & 0,77 & 0,11 & 1 & 0,81 & 0,80 & 0,82 & 44,22 & 0,59 & 0,75 & 0,00 & 0,00 & 0,80 & 0,77 & 0,81 & 43,93 \\
\hline D3S1 & 0,67 & 0,84 & 0,09 & 4,82 & 0,73 & 0,83 & 0,67 &, 27 & 0,47 & 0,68 & 0,00 & 0,00 & 0,83 & 0,78 & 0,87 & 47,08 \\
\hline D4S3248 & 0,80 & 0,78 & 0,80 & 42,93 & 0,74 & 0,73 & 0,98 & 53,13 & 0,75 & 0,73 & 0,42 & 22,60 & 0,79 & 0,76 & 0,80 & 43,40 \\
\hline D4S2366 & 0,67 & 0,79 & 0,49 & 26,37 & 0,64 & 0,78 & 0,15 & 7,90 & 0,68 & 0,72 & 0,38 & 20,33 & 0,77 & 0,82 & 0,09 & 4,71 \\
\hline D4S2368 & 0,67 & 0,75 & 0,29 & 15,80 & 0,64 & 0,79 & 0,26 & 13,88 & 0,66 & 0,68 & 0,03 & 1,85 & 0,74 & 0,73 & 0,84 & 45,57 \\
\hline D5S816 & 0,60 & 0,80 & 0,18 & 9,65 & 0,80 & 0,85 & 0,65 & 35,06 & 0,60 & 0,67 & 0,14 & 7,31 & 0,80 & 0,81 & 0,63 & 34,08 \\
\hline D5S2500 & 0,63 & 0,90 & 0,09 & 5,03 & 0,73 & 0,80 & 0,38 & 20,51 & 0,63 & 0,73 & 0,03 & 1,88 & 0,79 & 0,83 & 0,70 & 37,70 \\
\hline GATA112F & 0,67 & 0,77 & 0,27 & 14,49 & 0,71 & 0,78 & 0,23 &, 29 & 0,73 & 0,74 & 0,01 & 0,65 & 0,69 & 0,69 & 0,48 & 25,86 \\
\hline D6S474 & 0,73 & 0,82 & 0,22 & 11,77 & 0,77 & 0,79 & 0,98 & 53,10 & 0,72 & 0,79 & 0,03 & 1,51 & 0,78 & 0,78 & 0,91 & 49,07 \\
\hline D6S1040 & 0,64 & 0,67 & 0,84 & 45,19 & 0,81 & 0,78 & 0,59 & 31,99 & 0,71 & 0,72 & 0,18 & 9,92 & 0,74 & 0,73 & 0,43 & 23,29 \\
\hline D7S2846 & 0,36 & 0,72 & 0,01 & 0,39 & 0,76 & 0,73 & 0,85 & 45,78 & 0,73 & 0,77 & 0,78 & 42,14 & 0,68 & 0,74 & 0,19 & 10,36 \\
\hline D7S3061 & 0,71 & 0,84 & 0,84 & 45,42 & 0,55 & 0,83 & 0,01 & 0,77 & 0,44 & 0,51 & 0,06 & 2,99 & 0,79 & 0,84 & 0,68 & 36,55 \\
\hline D7S821 & 0,80 & 0,85 & 0,95 & 51,20 & 0,90 & 0,85 & 0,97 & 52,53 & 0,82 & 0,80 & 0,37 & 19,89 & 0,71 & 0,83 & 0,00 & 0,00 \\
\hline
\end{tabular}




\begin{tabular}{|c|c|c|c|c|c|c|c|c|c|c|c|c|c|c|c|c|}
\hline 3047 & 33 & 0,65 & ,01 & 0,29 & 0,70 & 0,72 & 0,03 & 1,52 & 0,69 & 0,69 & 0,16 & 8,44 & 0,73 & 0,72 & 0,36 & \\
\hline ГATG002P & ,73 & 0,73 & 0,13 & 7,11 & 0,85 & 0,74 & 0,06 & 3,07 & 0,61 & 0,64 & 0,06 & 3,10 & 0,72 & 0,71 & 0,25 & 13,36 \\
\hline D8S1136 & 0,62 & 0,67 & 0,41 & 22,39 & 0,43 & 0,64 & 0,00 & 0,13 & 0,63 & 0,74 & 0,02 & 1,25 & 0,71 & 0,74 & 0,72 & 3,74 \\
\hline S1128 & ,57 & 0,78 & ,31 & 16,76 & 67 & 0,77 & 23 & 2,45 & 0,76 & 0,80 & 0,00 & 0,00 & 0,77 & 0,78 & 0,97 & 2,44 \\
\hline 352324 & 0,64 & 0,75 & 0,10 & 5,65 & 0,62 & 0,78 & 0,20 & 0,71 & 0,63 & 0,71 & 0,19 & 10,08 & 0,64 & 0,78 & 0,00 & 0,03 \\
\hline D9S301 & 0,92 & 0,80 & 0,03 & 1,54 & 0,95 & 0,83 & 0,02 & 1,34 & 0,61 & 0,59 & 0,02 & 1,27 & 0,77 & 0,82 & 0,19 & 10,13 \\
\hline $9 S 922$ & 0,54 & 0,73 & 0,28 & 14,86 & 0,67 & 0,77 & 0,29 & 15,50 & 0,56 & 0,58 & 0,68 & 36,51 & 0,73 & 0,78 & 0,14 & 7,30 \\
\hline S1121 & 0,64 & 0,63 & 0,77 & 41,50 & 0,76 & 0,75 & 0,17 & 9,20 & 0,68 & 0,75 & 0,00 & 0,00 & 0,71 & 0,76 & 0,23 & 12,46 \\
\hline 122 & 0,64 & 0,72 & 0,87 & 5,76 & 0,52 & 0,67 & 20 & 0,57 & 0,65 & 0,48 & 0,00 & 0,00 & 0,66 & 0,68 & 0,42 & 22,74 \\
\hline 95934 & 0,87 & 0,79 & 0,68 & 36,82 & 0,73 & 0,80 & 0,30 & 16,21 & 0,63 & 0,78 & 0,00 & 0,00 & 0,79 & 0,77 & 0,14 & 7,59 \\
\hline D10S1435 & 0,57 & 0,76 & 0,03 & 1,44 & 0,69 & 0,82 & 0,23 & 12,53 & 0,65 & 0,68 & 0,95 & 51,50 & 0,68 & 0,75 & 0,12 & 6,45 \\
\hline 248 & 0,86 & 0,78 & 0,16 & 8,54 & 0,81 & 0,73 & 0,68 & 36,88 & 0,63 & 0,65 & 0,22 & 1,63 & 0,77 & 0,76 & 0,56 & 30,34 \\
\hline $10 \$ 1426$ & 0,67 & 0,64 & 0,39 & 20,82 & 0,67 & 0,76 & 0,00 & 0,05 & 0,70 & 0,67 & 0,20 & 10,86 & 0,77 & 0,72 & 0,07 & 3,66 \\
\hline 470 & 0,79 & 0,80 & 0,69 & 37,02 & 0,64 & 0,77 & 0,15 & 7,95 & 0,75 & 0,78 & 0,97 & 52,18 & 0,80 & 0,80 & 0,77 & 41,73 \\
\hline $10 S 2327$ & 0,64 & 0,73 & 0,38 & 20,71 & 0,48 & 0,60 & 0,25 & 13,24 & 0,35 & 0,36 & 0,47 & 25,60 & 0,65 & 0,64 & 0,92 & 49,61 \\
\hline D11S2365 & 0,64 & 0,64 & 0,87 & 47,02 & 0,45 & 0,63 & 0,10 & 5,48 & 0,63 & 0,72 & 0,09 & 5,02 & 0,68 & 0,68 & 0,05 & 2,79 \\
\hline D12S1300 & 0,67 & 0,76 & 0,26 & 13,97 & 0,55 & 0,67 & 0,10 & 5,39 & 0,67 & 0,72 & 0,69 & 37,37 & 0,70 & 0,72 & 0,21 & 11,43 \\
\hline 95 & 0,40 & 0,69 & 0,13 & 6,79 & 0,62 & 0,78 & 0,02 & 1,08 & 0,67 & 0,75 & 0,04 & 1,97 & 0,75 & 0,77 & 0,24 & 12,75 \\
\hline $13 \$ 317$ & 0,36 & 0,54 & 0,06 & 3,05 & 0,70 & 0,79 & 0,42 & 2,72 & 0,78 & 0,80 & 0,69 & 37,49 & 0,77 & 0,81 & 0,44 & 23,79 \\
\hline D13S1807 & 0,60 & 0,76 & 0,57 & 31,00 & 0,67 & 0,77 & 0,61 & 33,10 & 0,59 & 0,63 & 0,06 & 3,13 & 0,74 & 0,76 & 0,91 & 48,88 \\
\hline D13S800 & 0,80 & 0,73 & 0,99 & 53,32 & 0,81 & 0,72 & 0,19 & 10,04 & 0,73 & 0,75 & 0,02 & 1,15 & 0,74 & 0,77 & 0,50 & 26,97 \\
\hline D14S1434 & 0,53 & 0,67 & 0,17 & 9,06 & 0,59 & 0,70 & 0,53 & 28,42 & 0,58 & 0,54 & 0,15 & 8,26 & 0,66 & 0,70 & 0,10 & 5,28 \\
\hline D15S1515 & 0,60 & 0,82 & 0,34 & 18,61 & 0,77 & 0,75 & 0,42 & 22,43 & 0,61 & 0,68 & 0,07 & 4,04 & 0,71 & 0,76 & 0,42 & 22,80 \\
\hline D16S3253 & 0,73 & 0,73 & 0,58 & 31,26 & 0,59 & 0,73 & 0,20 & 10,68 & 0,56 & 0,64 & 0,29 & 15,74 & 0,68 & 0,72 & 0,56 & 30,09 \\
\hline D16S539 & 0,54 & 0,79 & 0,07 & 4,02 & 0,81 & 0,78 & 0,32 & 17,06 & 0,76 & 0,75 & 0,12 & 6,65 & 0,77 & 0,80 & 0,18 & 9,71 \\
\hline GATA64B & 0,67 & 0,63 & 0,57 & 30,65 & 0,62 & 0,76 & 0,09 & 4,78 & 0,71 & 0,72 & 0,93 & 50,02 & 0,68 & 0,74 & 0,47 & 25,26 \\
\hline GATA63G & 0,46 & 0,62 & 0,28 & 15,00 & 0,64 & 0,67 & 0,36 & 19,54 & 0,52 & 0,60 & 0,03 & 1,68 & 0,63 & 0,73 & 0,00 & 0,21 \\
\hline $17 S 1299$ & 0,43 & 0,71 & 0,12 & 6,54 & 0,57 & 0,48 & 0,07 & 3,68 & 0,53 & 0,56 & 0,08 & 4,22 & 0,60 & 0,65 & 0,03 & 1,76 \\
\hline
\end{tabular}




\begin{tabular}{|c|c|c|c|c|c|c|c|c|c|c|c|c|c|c|c|c|}
\hline D18S877 & 0,73 & 0,77 & 0,80 & 43,01 & 0,73 & 0,68 & 0,90 & 48,65 & 0,61 & 0,72 & 0,01 & 0,70 & 0,69 & 0,71 & 0,12 & 6,60 \\
\hline D18S535 & 0,79 & 0,73 & 0,98 & 53,16 & 0,71 & 0,79 & 0,28 & 14,98 & 0,62 & 0,72 & 0,07 & 3,54 & 0,77 & 0,78 & 0,15 & 8,25 \\
\hline 559 & 0,67 & 0,79 & ,41 & 22,31 & 0,71 & 0,75 & 0,64 & 4,68 & 0,58 & 0,67 & 0,26 & 14,00 & 0,73 & 0,76 & 0,04 & 2,32 \\
\hline D20S482 & 0,50 & 0,76 & 0,03 & 1,79 & 0,52 & 0,69 & 0,21 & 11,61 & 0,61 & 0,70 & 0,03 & 1,40 & 0,66 & 0,70 & 0,45 & 24,17 \\
\hline D22S689 & 0,60 & 0,74 & 0,59 & 31,79 & 0,70 & 0,80 & 0,73 & 39,30 & 0,66 & 0,71 & 0,04 & 1,98 & 0,70 & 0,73 & 0,10 & 5,36 \\
\hline
\end{tabular}

Tabela 4A. Estimativas de Hardy-Weinberg para os loci de microssatélites do MHC para as populações Africana, Europeia, Amerínida e de Belém. Onde $\mathrm{HO}=$ Heterozigose observada; $\mathrm{HE}=$ Heterozigose esperada; $p=p=v a l o r ; p$-cor= $p$-valor corrigida para múltiplos testes.

\begin{tabular}{lrrrrrrrrrrrrrrrr}
\hline & \multicolumn{4}{c}{ Africanos } & \multicolumn{1}{c}{ Europeus } & \multicolumn{4}{c}{ Ameríndios } & \multicolumn{4}{c}{ Belém } \\
\hline Locus & HO & HE & P & P-corr & HO & HE & P & P-corr & HO & HE & P & P-corr & HO & HE & P & P-corr \\
\hline & 0,600 & 0,643 & 0,096 & 0,673 & 0,500 & 0,688 & 0,041 & 0,288 & 0,718 & 0,683 & 0,386 & 2,703 & 0,706 & 0,730 & 0,831 & 5,822 \\
MICA & 0 & 7 & 2 & 4 & 0 & 5 & 2 & 5 & 8 & 6 & 2 & 5 & 9 & 3 & 8 & 9 \\
D6S292 & 0,666 & 0,659 & 0,860 & 6,020 & 0,545 & 0,689 & 0,280 & 1,961 & 0,344 & 0,506 & 0,000 & 0,001 & 0,232 & 0,641 & 0,000 & 0,000 \\
8 & 7 & 8 & 1 & 8 & 5 & 2 & 1 & 0 & 0 & 0 & 2 & 4 & 0 & 9 & 0 & 0 \\
& 0,538 & 0,732 & 0,047 & 0,330 & 0,681 & 0,793 & 0,393 & 2,751 & 0,697 & 0,706 & 0,621 & 4,353 & 0,645 & 0,785 & 0,000 & 0,002 \\
HLABC & 5 & 3 & 2 & 5 & 8 & 9 & 1 & 5 & 5 & 2 & 9 & 3 & 0 & 6 & 3 & 1 \\
D6S292 & 0,800 & 0,873 & 0,679 & 4,753 & 0,772 & 0,862 & 0,000 & 0,003 & 0,741 & 0,798 & 0,006 & 0,045 & 0,877 & 0,867 & 0,559 & 3,917 \\
8 & 0 & 6 & 0 & 1 & 7 & 6 & 5 & 3 & 9 & 2 & 5 & 2 & 6 & 8 & 6 & 1 \\
& 0,785 & 0,915 & 0,148 & 1,036 & 0,833 & 0,942 & 0,124 & 0,868 & 0,808 & 0,882 & 0,000 & 0,000 & 0,889 & 0,933 & 0,582 & 4,080 \\
D6S265 & 7 & 3 & 1 & 6 & 3 & 9 & 0 & 1 & 3 & 6 & 1 & 6 & 5 & 9 \\
D6S297 & 0,357 & 0,735 & 0,007 & 0,054 & 0,476 & 0,745 & 0,004 & 0,034 & 0,432 & 0,599 & 0,000 & 0,000 & 0,772 & 0,779 & 0,712 & 4,987 \\
2 & 1 & 5 & 8 & 6 & 2 & 6 & 9 & 2 & 0 & 2 & 0 & 0 & 3 & 8 & 4 & 1 \\
& 0,428 & 0,751 & 0,004 & 0,031 & 0,619 & 0,737 & 0,171 & 1,199 & 0,330 & 0,435 & 0,009 & 0,067 & 0,648 & 0,719 & 0,103 & 0,724 \\
G51152 & 6 & 3 & 5 & 6 & 1 & 5 & 4 & 5 & 7 & 7 & 7 & 6 & 4 & 9 & 4 & 0 \\
\hline
\end{tabular}


Tabela 5A. Estimativas de Hardy-Weinberg para os loci de microssatélites genômicos para as populações Tiriyó, Arara Laranjal, Urubu-Kaapor, Awá-Guajá. Onde HO= Heterozigose observada; HE= Heterozigose esperada; $p=p=$ valor; $p$-cor= $p$-valor corrigida para múltiplos testes.

\begin{tabular}{|c|c|c|c|c|c|c|c|c|c|c|c|c|c|c|c|c|}
\hline \multirow[t]{2}{*}{ POPUÇÕES } & \multicolumn{4}{|c|}{ Tiriyó } & \multicolumn{4}{|c|}{ Arara do Laranjal } & \multicolumn{4}{|c|}{ Urubu Kaapor } & \multicolumn{4}{|c|}{ Awa-Guajá } \\
\hline & & & & P- & & & & P- & & & & P- & & & & P- \\
\hline \multirow[t]{2}{*}{ Locus } & $\mathrm{HO}$ & $\mathrm{HE}$ & $\mathrm{P}$ & corr & $\mathrm{HO}$ & $\mathrm{HE}$ & $\mathrm{P}$ & corr & $\mathrm{HO}$ & $\mathrm{HE}$ & $\mathrm{P}$ & corr & $\mathrm{HO}$ & $\mathrm{HE}$ & $\mathrm{P}$ & corr \\
\hline & 0,7 & 0,6 & 0,2 & 14,4 & 0,5 & 0,6 & 0,6 & 33,6 & 0,2 & 0,1 & 1,0 & 54,0 & 0,6 & 0,5 & 1,0 & 54,0 \\
\hline \multirow[t]{2}{*}{ D1S551 } & 5 & 8 & 7 & 9 & 0 & 3 & 2 & 6 & 0 & 9 & 0 & 0 & 4 & 0 & 0 & 0 \\
\hline & 0,6 & 0,8 & 0,1 & & 0,6 & 0,6 & 1,0 & 54,0 & 0,7 & 0,7 & 0,2 & 11,7 & 0,6 & 0,7 & 0,5 & 28,6 \\
\hline \multirow[t]{2}{*}{ NAD1S_3 } & 7 & 3 & 4 & 7,78 & 3 & 6 & 0 & 0 & 0 & 5 & 2 & 4 & 4 & 9 & 3 & 3 \\
\hline & 0,7 & 0,7 & 0,4 & 25,8 & 0,3 & 0,3 & 0,5 & 28,1 & 0,6 & 0,7 & 0,2 & 10,9 & 0,5 & 0,5 & 0,6 & 35,6 \\
\hline D1S1660 & 3 & 1 & 8 & 8 & 1 & 8 & 2 & 4 & 3 & 0 & 0 & 2 & 0 & 0 & 6 & 3 \\
\hline GATA148G10P_ & 0,4 & 0,7 & 0,2 & 13,1 & 0,7 & 0,5 & 0,1 & & 0,4 & 0,6 & 0,2 & 14,0 & 0,5 & 0,4 & 1,0 & 54,0 \\
\hline \multirow[t]{2}{*}{2} & 5 & 1 & 4 & 4 & 3 & 8 & 3 & 6,76 & 5 & 2 & 6 & 4 & 5 & 6 & 0 & 0 \\
\hline & 0,7 & 0,8 & 0,0 & & 0,7 & 0,8 & 0,1 & & 0,6 & 0,6 & 0,3 & 20,8 & 0,7 & 0,7 & 0,5 & 31,8 \\
\hline \multirow[t]{2}{*}{ D2S1328 } & 3 & 0 & 5 & 2,73 & 5 & 0 & 3 & 7,20 & 0 & 8 & 9 & 8 & 3 & 7 & 9 & 5 \\
\hline & 0,8 & 0,7 & 0,5 & 29,1 & 0,3 & 0,3 & 0,4 & 24,8 & 0,5 & 0,6 & 0,0 & & 0,1 & 0,2 & 0,1 & \\
\hline \multirow[t]{2}{*}{ D2S1391 } & 1 & 3 & 4 & 9 & 3 & 5 & 6 & 6 & 5 & 7 & 1 & 0,76 & 8 & 6 & 4 & 7,65 \\
\hline & 0,3 & 0,3 & 1,0 & 54,0 & 0,4 & 0,5 & 0,2 & 12,8 & 0,2 & 0,3 & 0,4 & 25,2 & 0,1 & 0,1 & 1,0 & 54,0 \\
\hline \multirow[t]{2}{*}{ D2S2968 } & 6 & 0 & 0 & 0 & 0 & 4 & 4 & 4 & 5 & 0 & 7 & 3 & 8 & 8 & 0 & 0 \\
\hline & 0,7 & 0,6 & 0,6 & 35,1 & 0,8 & 0,7 & 0,9 & 49,6 & 0,5 & 0,4 & 0,6 & 32,8 & 0,5 & 0,3 & 1,0 & 54,0 \\
\hline \multirow{2}{*}{ GATA146B10_3 } & 3 & 0 & 5 & 9 & 1 & 1 & 2 & 6 & 5 & 5 & 1 & 1 & 0 & 9 & 0 & 0 \\
\hline & 0,7 & 0,8 & 0,4 & 22,5 & 0,5 & 0,7 & 0,3 & 18,5 & 0,6 & 0,8 & 0,1 & & 0,5 & 0,5 & 1,0 & 54,0 \\
\hline \multirow[t]{2}{*}{ D3S3039 } & 3 & 0 & 2 & 6 & 0 & 1 & 4 & 8 & 3 & 1 & 6 & 8,77 & 7 & 8 & 0 & 0 \\
\hline & 0,6 & 0,6 & 0,3 & 17,4 & 0,5 & 0,5 & 0,1 & & 0,4 & 0,6 & 0,3 & 16,4 & 0,6 & 0,6 & 1,0 & 54,0 \\
\hline \multirow[t]{2}{*}{ D3S1763 } & 0 & 9 & 2 & 0 & 6 & 9 & 2 & 6,47 & 4 & 4 & 0 & 5 & 0 & 2 & 0 & 0 \\
\hline & 0,8 & 0,8 & 0,9 & 53,1 & 0,7 & 0,5 & 0,2 & 15,4 & 0,6 & 0,6 & 0,8 & 46,6 & 0,4 & 0,4 & 0,6 & 32,6 \\
\hline D4S3248 & 8 & 4 & 8 & 7 & 5 & 6 & 9 & 6 & 5 & 5 & 6 & 1 & 5 & 7 & 1 & \\
\hline
\end{tabular}




\begin{tabular}{|c|c|c|c|c|c|c|c|c|c|c|c|c|c|c|c|c|}
\hline & 0,8 & 0,7 & 0,4 & 22,1 & 0,5 & 0,4 & 1,0 & 54,0 & 0,5 & 0,4 & 0,7 & 39,4 & 0,6 & 0,6 & 1,0 & 54,0 \\
\hline \multirow[t]{2}{*}{ D4S2366 } & 1 & 4 & 1 & 2 & 0 & 7 & 0 & 0 & 5 & 3 & 3 & 9 & 7 & 2 & 0 & 0 \\
\hline & 0,8 & 0,7 & 0,5 & 29,0 & 0,5 & 0,6 & 0,8 & 46,5 & 0,5 & 0,5 & 0,8 & 48,0 & 0,9 & 0,7 & 0,8 & 45,4 \\
\hline \multirow[t]{2}{*}{ D4S2368 } & 1 & 4 & 4 & 4 & 6 & 1 & 6 & 8 & 8 & 6 & 9 & 3 & 0 & 4 & 4 & 4 \\
\hline & 0,7 & 0,7 & 0,5 & 31,9 & 0,5 & 0,5 & 0,8 & 44,7 & 0,4 & 0,6 & 0,0 & & 0,5 & 0,4 & 1,0 & 54,0 \\
\hline \multirow[t]{2}{*}{ D5S816 } & 5 & 5 & 9 & 1 & 0 & 9 & 3 & 2 & 0 & 2 & 8 & 4,34 & 5 & 5 & 0 & 0 \\
\hline & 0,6 & 0,8 & 0,0 & & 0,6 & 0,7 & 0,7 & 39,3 & 0,6 & 0,5 & 0,9 & 48,8 & 0,3 & 0,5 & 0,4 & 26,6 \\
\hline \multirow[t]{2}{*}{ D5S2500 } & 9 & 0 & 4 & 2,34 & 9 & 2 & 3 & 6 & 3 & 1 & 0 & 2 & 3 & 0 & 9 & 7 \\
\hline & 0,7 & 0,8 & 0,2 & 14,1 & 0,6 & 0,7 & 0,4 & 26,0 & 0,5 & 0,6 & 0,2 & 12,8 & 0,8 & 0,7 & 0,9 & 48,8 \\
\hline \multirow[t]{2}{*}{ GATA112F02P_6 } & 3 & 0 & 6 & 7 & 9 & 1 & 8 & 9 & 5 & 6 & 4 & 8 & 2 & 7 & 0 & 6 \\
\hline & 0,8 & 0,7 & 0,3 & 18,5 & 0,8 & 0,6 & 0,6 & 32,5 & 0,6 & 0,5 & 0,2 & 15,1 & 0,6 & 0,5 & 1,0 & 54,0 \\
\hline \multirow[t]{2}{*}{ D6S474 } & 8 & 6 & 4 & 4 & 1 & 9 & 0 & 5 & 5 & 9 & 8 & 4 & 4 & 6 & 0 & 0 \\
\hline & 0,7 & 0,6 & 0,2 & 13,2 & 0,5 & 0,6 & 0,8 & 45,7 & 0,7 & 0,7 & 0,5 & 31,5 & 0,7 & 0,6 & 1,0 & 54,0 \\
\hline \multirow[t]{2}{*}{ D6S1040 } & 3 & 8 & 5 & 8 & 6 & 0 & 5 & 1 & 0 & 1 & 8 & 7 & 3 & 5 & 0 & 0 \\
\hline & 0,7 & 0,7 & 0,8 & 46,8 & 0,8 & 0,7 & 0,8 & 45,5 & 0,6 & 0,7 & 0,4 & 22,0 & 0,8 & 0,6 & 0,3 & 20,1 \\
\hline \multirow[t]{2}{*}{ D7S2846 } & 5 & 8 & 7 & 8 & 5 & 1 & 4 & 2 & 8 & 0 & 1 & 6 & 0 & 0 & 7 & 9 \\
\hline & 0,6 & 0,5 & 0,2 & 10,7 & 0,5 & 0,5 & 0,4 & 23,4 & 0,5 & 0,6 & 0,5 & 31,3 & 0,1 & 0,2 & 0,1 & \\
\hline \multirow[t]{2}{*}{ D7S3061 } & 3 & 7 & 0 & 4 & 5 & 9 & 3 & 7 & 5 & 1 & 8 & 0 & 0 & 7 & 6 & 8,50 \\
\hline & 0,9 & 0,8 & 0,8 & 44,2 & 0,8 & 0,8 & 0,8 & 43,6 & 0,9 & 0,8 & 0,8 & 48,2 & 0,6 & 0,5 & 1,0 & 54,0 \\
\hline \multirow[t]{2}{*}{ D7S821 } & 3 & 4 & 2 & 1 & 6 & 4 & 1 & 2 & 0 & 2 & 9 & 9 & 4 & 5 & 0 & 0 \\
\hline & 0,8 & 0,6 & 0,5 & 30,8 & 0,6 & 0,6 & 0,6 & 35,2 & 0,6 & 0,4 & 0,4 & 23,6 & 0,4 & 0,6 & 0,4 & 24,8 \\
\hline \multirow[t]{2}{*}{ D7S3047 } & 0 & 8 & 7 & 4 & 3 & 4 & 5 & 2 & 0 & 9 & 4 & 2 & 5 & 5 & 6 & 5 \\
\hline & 0,5 & 0,6 & 0,3 & 19,8 & 0,5 & 0,4 & 0,4 & 26,3 & 0,7 & 0,6 & 1,0 & 54,0 & 0,5 & 0,4 & 1,0 & 54,0 \\
\hline \multirow[t]{2}{*}{ TATG002P_7 } & 8 & 7 & 7 & 3 & 0 & 6 & 9 & 4 & 2 & 7 & 0 & 0 & 5 & 4 & 0 & 0 \\
\hline & 0,6 & 0,6 & 1,0 & 54,0 & 0,7 & 0,7 & 0,6 & 35,1 & 0,8 & 0,7 & 0,1 & & 0,5 & 0,6 & 0,1 & \\
\hline \multirow[t]{2}{*}{ D8S1136 } & 4 & 4 & 0 & 0 & 5 & 4 & 5 & 4 & 0 & 3 & 8 & 9,81 & 5 & 1 & 3 & 7,06 \\
\hline & 0,7 & 0,8 & 0,2 & 14,1 & 0,8 & 0,6 & 0,0 & & 0,8 & 0,8 & 0,8 & 43,3 & 0,4 & 0,6 & 0,0 & \\
\hline D8S1128 & 5 & 2 & 6 & 9 & 8 & 4 & 2 & 1,17 & 5 & 1 & 0 & 8 & 5 & 7 & 7 & 4,02 \\
\hline D8S2324 & 0,7 & 0,7 & 0,7 & 42,9 & 0,5 & 0,6 & 0,1 & 8,93 & 0,6 & 0,6 & 0,9 & 48,9 & 0,4 & 0,5 & 0,7 & 39,7 \\
\hline
\end{tabular}




\begin{tabular}{|c|c|c|c|c|c|c|c|c|c|c|c|c|c|c|c|c|}
\hline \multirow[t]{2}{*}{ D9S301 } & 7 & 8 & 7 & 7 & 3 & 8 & 0 & 5 & 0 & 9 & 9 & 6 & 0 & 4 & 8 & 7 \\
\hline & 0,6 & 0,6 & 0,9 & 49,8 & 0,4 & 0,6 & 0,2 & 15,0 & 0,5 & 0,5 & 0,5 & 29,9 & 0,5 & 0,4 & 1,0 & 54,0 \\
\hline \multirow[t]{2}{*}{ D9S922 } & 9 & 3 & 2 & 6 & 7 & 1 & 8 & 3 & 5 & 0 & 6 & 7 & 5 & 4 & 0 & 0 \\
\hline & 0,6 & 0,7 & 0,8 & 45,2 & 0,5 & 0,6 & 0,0 & & 0,5 & 0,6 & 0,3 & 16,5 & 0,8 & 0,7 & 0,4 & 24,6 \\
\hline \multirow[t]{2}{*}{ D9S1121 } & 7 & 0 & 4 & 0 & 5 & 2 & 3 & 1,75 & 5 & 4 & 1 & 7 & 2 & 5 & 6 & 9 \\
\hline & 0,7 & 0,6 & 0,9 & 48,5 & 0,6 & 0,4 & 0,1 & & 0,7 & 0,5 & 0,0 & & 0,1 & 0,1 & 1,0 & 54,0 \\
\hline \multirow[t]{2}{*}{ D9S1122 } & 3 & 1 & 0 & 3 & 9 & 9 & 5 & 8,27 & 5 & 2 & 7 & 4,03 & 8 & 7 & 0 & 0 \\
\hline & 0,7 & 0,7 & 0,7 & 40,8 & 0,5 & 0,6 & 0,0 & & 0,6 & 0,7 & 0,0 & & 0,7 & 0,8 & 0,3 & 20,3 \\
\hline \multirow[t]{2}{*}{ D9S934 } & 9 & 7 & 6 & 5 & 0 & 7 & 7 & 3,96 & 1 & 8 & 3 & 1,69 & 3 & 1 & 8 & 7 \\
\hline & 0,6 & 0,6 & 0,7 & 42,1 & 0,5 & 0,6 & 0,7 & 39,2 & 0,6 & 0,6 & 0,2 & 15,1 & 0,4 & 0,6 & 0,1 & \\
\hline \multirow[t]{2}{*}{ D10S1435 } & 4 & 8 & 8 & 0 & 7 & 1 & 3 & 4 & 3 & 3 & 8 & 0 & 4 & 9 & 8 & 9,79 \\
\hline & 0,7 & 0,6 & 1,0 & 54,0 & 0,3 & 0,5 & 0,2 & 14,4 & 0,6 & 0,7 & 0,0 & & 0,7 & 0,7 & 1,0 & 54,0 \\
\hline \multirow[t]{2}{*}{ D10S1248 } & 9 & 5 & 0 & 0 & 8 & 1 & 7 & 7 & 5 & 2 & 5 & 2,91 & 3 & 0 & 0 & 0 \\
\hline & 0,9 & 0,7 & 0,3 & 17,9 & 0,7 & 0,6 & 0,5 & 26,8 & 0,8 & 0,6 & 0,1 & & 0,3 & 0,5 & 0,2 & 12,2 \\
\hline \multirow[t]{2}{*}{ D10S1426 } & 3 & 7 & 3 & 7 & 1 & 3 & 0 & 7 & 5 & 7 & 1 & 6,00 & 6 & 4 & 3 & 1 \\
\hline & 0,5 & 0,7 & 0,0 & & 0,7 & 0,6 & 0,6 & 34,0 & 0,7 & 0,7 & 0,5 & 29,8 & 0,7 & 0,6 & 1,0 & 54,0 \\
\hline \multirow[t]{2}{*}{ D10S2470 } & 0 & 2 & 8 & 4,39 & 5 & 7 & 3 & 8 & 4 & 1 & 5 & 1 & 8 & 7 & 0 & 0 \\
\hline & 0,6 & 0,5 & 1,0 & 54,0 & 0,2 & 0,3 & 0,4 & 26,4 & 0,2 & 0,2 & 1,0 & 54,0 & 0,2 & 0,1 & 1,0 & 54,0 \\
\hline \multirow[t]{2}{*}{ D10S2327 } & 3 & 4 & 0 & 0 & 9 & 5 & 9 & 3 & 1 & 0 & 0 & 0 & 0 & 9 & 0 & 0 \\
\hline & 0,7 & 0,6 & 0,3 & 20,5 & 0,4 & 0,6 & 0,0 & & 0,7 & 0,7 & 0,8 & 43,1 & 0,3 & 0,6 & 0,1 & \\
\hline \multirow[t]{2}{*}{ D11S2365 } & 7 & 7 & 8 & 5 & 4 & 5 & 6 & 3,03 & 5 & 0 & 0 & 3 & 6 & 9 & 4 & 7,51 \\
\hline & 0,6 & 0,6 & 0,3 & 19,2 & 0,6 & 0,6 & 0,4 & 25,6 & 0,6 & 0,6 & 0,7 & 39,9 & 0,4 & 0,6 & 0,3 & 19,4 \\
\hline \multirow[t]{2}{*}{ D12S1300 } & 3 & 8 & 6 & 6 & 0 & 6 & 8 & 7 & 5 & 2 & 4 & 4 & 5 & 0 & 6 & 9 \\
\hline & 0,8 & 0,7 & 0,3 & 20,5 & 0,4 & 0,5 & 0,5 & 29,8 & 0,6 & 0,6 & 0,2 & 15,7 & 0,5 & 0,5 & 1,0 & 54,0 \\
\hline \multirow[t]{2}{*}{ D12S395 } & 0 & 7 & 8 & 7 & 7 & 0 & 5 & 7 & 8 & 9 & 9 & 1 & 0 & 7 & 0 & 0 \\
\hline & 0,8 & 0,8 & 0,8 & 47,3 & 0,6 & 0,8 & 0,1 & & 0,8 & 0,8 & 0,5 & 26,9 & 0,7 & 0,7 & 0,5 & 27,0 \\
\hline D13S317 & 7 & 5 & 8 & 2 & 9 & 0 & 2 & 6,46 & 0 & 0 & 0 & 8 & 3 & 8 & 0 & 9 \\
\hline
\end{tabular}




\begin{tabular}{|c|c|c|c|c|c|c|c|c|c|c|c|c|c|c|c|c|}
\hline & 0,5 & 0,6 & 0,2 & 10,5 & 0,5 & 0,5 & 0,0 & & 0,5 & 0,5 & 0,0 & & 0,7 & 0,5 & 0,4 & 24,3 \\
\hline \multirow[t]{2}{*}{ D13S1807 } & 3 & 5 & 0 & 5 & 3 & 8 & 3 & 1,73 & 0 & 9 & 1 & 0,36 & 3 & 9 & 5 & 1 \\
\hline & 0,6 & 0,7 & 0,8 & 44,5 & 0,7 & 0,6 & 0,3 & 18,5 & 0,7 & 0,6 & 0,9 & 48,7 & 0,8 & 0,7 & 0,1 & \\
\hline \multirow[t]{2}{*}{ D13S800 } & 9 & 8 & 2 & 1 & 9 & 6 & 4 & 1 & 5 & 8 & 0 & 5 & 2 & 3 & 7 & 8,96 \\
\hline & 0,5 & 0,5 & 1,0 & 54,0 & 0,6 & 0,4 & 0,1 & & 0,7 & 0,4 & 0,0 & & 0,0 & 0,2 & 0,1 & \\
\hline \multirow[t]{2}{*}{ D14S1434 } & 6 & 1 & 0 & 0 & 9 & 7 & 0 & 5,14 & 0 & 9 & 8 & 4,08 & 9 & 5 & 4 & 7,79 \\
\hline & 0,8 & 0,7 & 0,3 & 19,0 & 0,5 & 0,4 & 0,5 & 29,9 & 0,4 & 0,6 & 0,1 & & 0,7 & 0,5 & 0,3 & 18,9 \\
\hline \multirow[t]{2}{*}{ D15S1515 } & 7 & 6 & 5 & 5 & 6 & 8 & 6 & 9 & 5 & 0 & 8 & 9,65 & 3 & 7 & 5 & 9 \\
\hline & 0,7 & 0,7 & 0,7 & 39,0 & 0,3 & 0,6 & 0,1 & & 0,6 & 0,5 & 0,3 & 17,2 & 0,5 & 0,6 & 0,7 & 41,7 \\
\hline \multirow[t]{2}{*}{ D16S3253 } & 3 & 2 & 2 & 1 & 6 & 2 & 3 & 6,81 & 0 & 3 & 2 & 9 & 5 & 1 & 7 & 0 \\
\hline & 0,7 & 0,7 & 0,1 & & 0,7 & 0,7 & 0,4 & 22,3 & 0,8 & 0,7 & 0,4 & 26,4 & 0,6 & 0,7 & 0,9 & 51,0 \\
\hline \multirow[t]{2}{*}{ D16S539 } & 5 & 5 & 4 & 7,68 & 1 & 2 & 1 & 3 & 5 & 3 & 9 & 2 & 4 & 1 & 4 & 0 \\
\hline & 0,5 & 0,6 & 1,0 & 54,0 & 0,7 & 0,7 & 0,8 & 45,0 & 0,9 & 0,8 & 0,8 & 46,0 & 0,4 & 0,5 & 1,0 & 54,0 \\
\hline \multirow[t]{2}{*}{ GATA64B04P_17 } & 6 & 3 & 0 & 0 & 5 & 1 & 3 & 8 & 0 & 0 & 5 & 9 & 5 & 0 & 0 & 0 \\
\hline & 0,3 & 0,4 & 0,4 & 24,5 & 0,5 & 0,7 & 0,1 & & 0,5 & 0,5 & 1,0 & 54,0 & 0,5 & 0,5 & 1,0 & 54,0 \\
\hline \multirow[t]{2}{*}{ GATA63G01_17 } & 8 & 6 & 5 & 4 & 7 & 4 & 4 & 7,39 & 8 & 7 & 0 & 0 & 0 & 7 & 0 & 0 \\
\hline & 0,6 & 0,5 & 0,1 & & 0,5 & 0,5 & 1,0 & 54,0 & 0,4 & 0,4 & 1,0 & 54,0 & 0,7 & 0,5 & 0,5 & 28,0 \\
\hline \multirow[t]{2}{*}{ D17S1299 } & 0 & 2 & 0 & 5,23 & 3 & 4 & 0 & 0 & 5 & 8 & 0 & 0 & 0 & 2 & 2 & 8 \\
\hline & 0,6 & 0,7 & 0,7 & 42,8 & 0,5 & 0,5 & 0,4 & 26,7 & 0,4 & 0,5 & 0,3 & 17,0 & 0,2 & 0,3 & 0,4 & 23,6 \\
\hline \multirow[t]{2}{*}{ D18S877 } & 9 & 6 & 9 & 0 & 3 & 3 & 9 & 1 & 7 & 2 & 2 & 3 & 7 & 7 & 4 & 8 \\
\hline & 0,9 & 0,7 & 0,9 & 51,2 & 0,4 & 0,4 & 0,2 & 14,7 & 0,7 & 0,7 & 0,3 & 20,0 & 0,8 & 0,7 & 0,7 & 37,6 \\
\hline \multirow[t]{2}{*}{ D18S535 } & 3 & 7 & 5 & 3 & 0 & 9 & 7 & 8 & 5 & 1 & 7 & 7 & 2 & 1 & 0 & 3 \\
\hline & 0,6 & 0,6 & 0,7 & 38,3 & 0,4 & 0,3 & 1,0 & 54,0 & 0,7 & 0,6 & 0,2 & 13,5 & 0,4 & 0,5 & 0,3 & 16,6 \\
\hline \multirow[t]{2}{*}{ D19S559 } & 0 & 6 & 1 & 5 & 3 & 6 & 0 & 0 & 5 & 4 & 5 & 7 & 5 & 2 & 1 & 9 \\
\hline & 0,8 & 0,7 & 1,0 & 54,0 & 0,6 & 0,6 & 0,7 & 38,5 & 0,6 & 0,7 & 0,0 & & 0,4 & 0,6 & 0,2 & 10,7 \\
\hline \multirow[t]{2}{*}{ D20S482 } & 1 & 3 & 0 & 0 & 3 & 8 & 1 & 9 & 0 & 2 & 2 & 1,04 & 5 & 2 & 0 & 9 \\
\hline & 0,6 & 0,8 & 0,1 & & 0,7 & 0,7 & 0,1 & & 0,7 & 0,7 & 0,6 & 33,0 & 0,6 & 0,5 & 0,5 & 30,9 \\
\hline D22S689 & 3 & 1 & 2 & 6,58 & 5 & 7 & 7 & 9,34 & 5 & 4 & 1 & 7 & 4 & 7 & 7 & 3 \\
\hline
\end{tabular}


Tabela 5B. Estimativas de Hardy-Weinberg para os loci de microssatélites genômicos para as populações Parakanã, Assurini, Kayapó Krokaimoro, Kayapó Xikrin. Onde HO= Heterozigose observada; $\mathrm{HE}=$ Heterozigose esperada; $p=p=v a l o r ; p-c o r=p-v a l o r$ corrigida para múltiplos testes.

\begin{tabular}{|c|c|c|c|c|c|c|c|c|c|c|c|c|c|c|c|c|}
\hline \multirow{2}{*}{$\begin{array}{l}\text { POPUÇÕES } \\
\text { Locus }\end{array}$} & \multicolumn{4}{|c|}{ Parakanã } & \multicolumn{4}{|c|}{ Assurini } & \multicolumn{4}{|c|}{ Krokaimoro } & \multicolumn{4}{|c|}{ Xikrin } \\
\hline & $\mathrm{HO}$ & $\mathrm{HE}$ & $P$ & $\begin{array}{l}\text { P- } \\
\text { corr }\end{array}$ & $\mathrm{HO}$ & $\mathrm{HE}$ & $\mathrm{P}$ & $\begin{array}{l}\text { P- } \\
\text { corr }\end{array}$ & $\mathrm{HO}$ & $\mathrm{HE}$ & $P$ & $\begin{array}{l}\text { P- } \\
\text { corr }\end{array}$ & $\mathrm{HO}$ & $\mathrm{HE}$ & $P$ & $\begin{array}{l}\text { P- } \\
\text { corr }\end{array}$ \\
\hline & 0,2 & 0,3 & 0,3 & 20,8 & 0,7 & 0,6 & 0,3 & 17,6 & 0,5 & 0,6 & 0,6 & 34,9 & 0,5 & 0,5 & 0,2 & 12,5 \\
\hline \multirow[t]{2}{*}{ D1S551 } & 2 & 7 & 4 & 3 & 5 & 6 & 3 & 3 & 6 & 4 & 5 & 8 & 5 & 8 & 3 & 5 \\
\hline & 0,7 & 0,8 & 0,3 & 23,8 & 0,7 & 0,6 & 0,2 & 14,4 & 0,6 & 0,8 & 0,0 & & 0,8 & 0,7 & 0,1 & \\
\hline \multirow[t]{2}{*}{ NAD1S_3 } & 8 & 2 & 9 & 3 & 4 & 9 & 7 & 5 & 7 & 0 & 6 & 3,16 & 9 & 6 & 6 & 8,90 \\
\hline & 0,7 & 0,6 & 1,0 & 61,0 & 0,5 & 0,7 & 0,1 & & 0,6 & 0,6 & 0,0 & & 0,7 & 0,7 & 0,9 & 51,5 \\
\hline D1S1660 & 8 & 6 & 0 & 0 & 6 & 1 & 5 & 8,11 & 5 & 7 & 7 & 3,72 & 0 & 1 & 5 & 6 \\
\hline GATA148G10P_ & 0,8 & 0,6 & 0,4 & 29,1 & 0,7 & 0,6 & 1,0 & 54,0 & 0,6 & 0,6 & 0,4 & 22,1 & 0,5 & 0,6 & 0,6 & 32,9 \\
\hline \multirow[t]{2}{*}{2} & 9 & 7 & 8 & 8 & 8 & 9 & 0 & 0 & 7 & 7 & 1 & 9 & 8 & 1 & 1 & 2 \\
\hline & 0,7 & 0,8 & 0,4 & 26,1 & 0,8 & 0,7 & 0,9 & 50,5 & 0,9 & 0,7 & 0,0 & & 0,8 & 0,7 & 0,9 & 53,6 \\
\hline \multirow[t]{2}{*}{ D2S1328 } & 8 & 0 & 3 & 2 & 5 & 7 & 4 & 8 & 4 & 7 & 6 & 2,97 & 0 & 6 & 9 & 6 \\
\hline & 0,2 & 0,2 & 1,0 & 61,0 & 0,6 & 0,5 & 0,3 & 17,2 & 0,7 & 0,5 & 0,6 & 36,5 & 0,7 & 0,6 & 0,7 & 38,1 \\
\hline \multirow[t]{2}{*}{ D2S1391 } & 2 & 2 & 0 & 0 & 0 & 4 & 2 & 4 & 2 & 9 & 8 & 1 & 4 & 0 & 1 & 9 \\
\hline & 0,3 & 0,2 & 1,0 & 61,0 & 0,3 & 0,2 & 1,0 & 54,0 & & & & & 0,2 & 0,2 & 1,0 & 54,0 \\
\hline \multirow[t]{2}{*}{ D2S2968 } & 3 & 9 & 0 & 0 & 3 & 9 & 0 & 0 & & & & 0,00 & 6 & 4 & 0 & 0 \\
\hline & 0,5 & 0,5 & 0,7 & 44,3 & 0,9 & 0,6 & 0,0 & & 0,5 & 0,5 & 0,3 & 19,0 & 0,6 & 0,6 & 0,8 & 45,2 \\
\hline \multirow[t]{2}{*}{ GATA146B10_3 } & 6 & 7 & 3 & 3 & 4 & 6 & 1 & 0,27 & 9 & 9 & 5 & 5 & 1 & 0 & 4 & 3 \\
\hline & 0,8 & 0,7 & 0,4 & 28,6 & 0,5 & 0,7 & 0,0 & & 0,4 & 0,6 & 0,0 & & 0,5 & 0,6 & 0,2 & 13,4 \\
\hline \multirow[t]{2}{*}{ D3S3039 } & 3 & 7 & 7 & 0 & 4 & 3 & 9 & 4,90 & 7 & 5 & 7 & 3,90 & 3 & 1 & 5 & 9 \\
\hline & 0,2 & 0,4 & 0,1 & & 0,4 & 0,6 & 0,1 & & 0,4 & 0,5 & 0,4 & 25,8 & 0,3 & 0,5 & 0,0 & \\
\hline \multirow[t]{2}{*}{ D3S1763 } & 5 & 3 & 4 & 8,38 & 5 & 8 & 1 & 5,73 & 4 & 3 & 8 & 5 & 7 & 9 & 5 & 2,49 \\
\hline & 1,0 & 0,8 & 0,8 & 53,6 & 0,8 & 0,7 & 0,2 & 10,5 & 0,7 & 0,6 & 0,7 & 40,6 & 0,7 & 0,7 & 0,9 & 50,8 \\
\hline D4S3248 & 0 & 5 & 8 & 7 & 0 & 4 & 0 & 5 & 2 & 2 & 5 & 6 & 5 & 4 & 4 & 5 \\
\hline
\end{tabular}




\begin{tabular}{|c|c|c|c|c|c|c|c|c|c|c|c|c|c|c|c|c|}
\hline & 0,8 & 0,6 & 0,5 & 32,1 & 0,5 & 0,7 & 0,0 & & 0,7 & 0,7 & 0,8 & 45,3 & 0,7 & 0,8 & 0,0 & \\
\hline \multirow[t]{2}{*}{ D4S2366 } & 9 & 5 & 3 & 9 & 6 & 1 & 0 & 0,08 & 1 & 1 & 4 & 2 & 9 & 1 & 2 & 0,94 \\
\hline & 0,7 & 0,8 & 0,2 & 14,5 & 0,6 & 0,5 & 0,8 & 46,9 & 0,5 & 0,7 & 0,1 & & 0,6 & 0,6 & 0,2 & 15,3 \\
\hline \multirow[t]{2}{*}{ D4S2368 } & 8 & 5 & 4 & 7 & 0 & 9 & 7 & 5 & 6 & 3 & 2 & 6,34 & 8 & 8 & 8 & 8 \\
\hline & 0,8 & 0,6 & 0,7 & 42,7 & 0,6 & 0,6 & 0,2 & 15,9 & 0,7 & 0,7 & 0,7 & 37,8 & 0,5 & 0,6 & 0,0 & \\
\hline \multirow[t]{2}{*}{ D5S816 } & 9 & 8 & 0 & 2 & 5 & 9 & 9 & 3 & 2 & 2 & 0 & 3 & 0 & 3 & 5 & 2,64 \\
\hline & 0,3 & 0,4 & 0,5 & 35,9 & 0,6 & 0,6 & 0,2 & 15,5 & 0,6 & 0,6 & 1,0 & 54,0 & 0,8 & 0,7 & 0,1 & \\
\hline \multirow[t]{2}{*}{ D5S2500 } & 8 & 9 & 9 & 1 & 0 & 8 & 9 & 0 & 5 & 9 & 0 & 0 & 3 & 2 & 5 & 8,25 \\
\hline & 0,6 & 0,6 & 1,0 & 61,0 & 0,8 & 0,7 & 0,9 & 51,1 & 0,7 & 0,7 & 0,1 & & 0,7 & 0,7 & 0,3 & 17,2 \\
\hline \multirow[t]{2}{*}{ GATA112F02P_6 } & 7 & 6 & 0 & 0 & 5 & 7 & 5 & 6 & 8 & 6 & 5 & 7,95 & 4 & 1 & 2 & 6 \\
\hline & 0,5 & 0,4 & 1,0 & 61,0 & 0,5 & 0,8 & 0,1 & & 0,9 & 0,7 & 0,6 & 37,4 & 0,7 & 0,7 & 0,2 & 13,3 \\
\hline \multirow[t]{2}{*}{ D6S474 } & 6 & 8 & 0 & 0 & 5 & 0 & 0 & 5,65 & 4 & 9 & 9 & 5 & 0 & 1 & 5 & 4 \\
\hline & 0,7 & 0,5 & 0,2 & 15,9 & 0,7 & 0,7 & 0,6 & 33,2 & 0,6 & 0,6 & 0,3 & 21,1 & 0,8 & 0,7 & 0,4 & 22,4 \\
\hline \multirow[t]{2}{*}{ D6S1040 } & 8 & 7 & 6 & 5 & 5 & 0 & 2 & 4 & 1 & 0 & 9 & 8 & 0 & 6 & 2 & 2 \\
\hline & 1,0 & 0,7 & 0,1 & 10,7 & 0,5 & 0,7 & 0,1 & & 0,6 & 0,7 & 0,6 & 32,2 & 0,8 & 0,7 & 0,3 & 18,1 \\
\hline \multirow[t]{2}{*}{ D7S2846 } & 0 & 5 & 8 & 1 & 0 & 1 & 1 & 5,77 & 7 & 6 & 0 & 0 & 0 & 9 & 4 & 8 \\
\hline & 0,3 & 0,4 & 0,5 & 32,1 & 0,5 & 0,5 & 0,8 & 43,8 & 0,2 & 0,3 & 0,1 & & 0,4 & 0,4 & 0,7 & 42,0 \\
\hline \multirow[t]{2}{*}{ D7S3061 } & 3 & 5 & 3 & 9 & 7 & 1 & 1 & 8 & 2 & 7 & 6 & 8,69 & 5 & 2 & 8 & 8 \\
\hline & 0,8 & 0,7 & 0,1 & & 0,8 & 0,8 & 0,5 & 27,6 & 0,6 & 0,7 & 0,6 & 35,1 & 0,8 & 0,7 & 0,4 & 24,7 \\
\hline \multirow[t]{2}{*}{ D7S821 } & 9 & 8 & 5 & 8,89 & 5 & 1 & 1 & 0 & 1 & 0 & 5 & 5 & 4 & 0 & 6 & 2 \\
\hline & 0,7 & 0,7 & 0,6 & 36,8 & 0,8 & 0,7 & 0,5 & 28,9 & 0,6 & 0,6 & 0,9 & 50,3 & 0,7 & 0,6 & 0,3 & 16,1 \\
\hline \multirow[t]{2}{*}{ D7S3047 } & 8 & 1 & 0 & 7 & 5 & 0 & 4 & 0 & 1 & 7 & 3 & 1 & 4 & 5 & 0 & 2 \\
\hline & 0,7 & 0,5 & 0,6 & 38,2 & 0,5 & 0,6 & 0,0 & & 0,5 & 0,6 & 0,3 & 19,7 & 0,6 & 0,5 & 0,4 & 25,9 \\
\hline \multirow[t]{2}{*}{ TATG002P_7 } & 1 & 8 & 3 & 4 & 0 & 2 & 7 & 3,68 & 9 & 7 & 6 & 0 & 8 & 8 & 8 & 8 \\
\hline & 0,6 & 0,7 & 0,6 & 39,5 & 0,4 & 0,6 & 0,0 & & 0,5 & 0,5 & 0,7 & 38,4 & 0,6 & 0,6 & 0,7 & 38,5 \\
\hline \multirow[t]{2}{*}{ D8S1136 } & 7 & 3 & 5 & 5 & 5 & 5 & 3 & 1,49 & 3 & 3 & 1 & 8 & 5 & 4 & 1 & 1 \\
\hline & 0,4 & 0,6 & 0,0 & & 0,9 & 0,7 & 0,3 & 17,9 & 0,7 & 0,7 & 0,2 & 13,9 & 0,8 & 0,8 & 0,0 & \\
\hline D8S1128 & 4 & 7 & 0 & 0,16 & 4 & 7 & 3 & 0 & 1 & 4 & 6 & 3 & 0 & 3 & 1 & 0,38 \\
\hline D8S2324 & 0,4 & 0,5 & 0,1 & 6,43 & 0,6 & 0,7 & 0,3 & 17,4 & 0,6 & 0,7 & 0,7 & 41,8 & 0,8 & 0,7 & 0,3 & 19,5 \\
\hline
\end{tabular}




\begin{tabular}{|c|c|c|c|c|c|c|c|c|c|c|c|c|c|c|c|c|}
\hline \multirow[t]{2}{*}{ D9S301 } & 4 & 7 & 0 & 0 & 4 & 6 & 6 & 3,30 & 0 & 3 & 9 & 5 & 0 & 6 & 5 & 8,16 \\
\hline & 0,5 & 0,6 & 0,3 & 21,5 & 0,5 & 0,5 & 0,3 & 20,4 & 0,7 & 0,5 & 0,1 & & 0,4 & 0,5 & 0,5 & 28,8 \\
\hline \multirow[t]{2}{*}{ D9S922 } & 6 & 5 & 5 & 9 & 3 & 8 & 8 & 9 & 2 & 2 & 4 & 7,38 & 5 & 4 & 3 & 0 \\
\hline & 0,8 & 0,7 & 0,6 & 39,3 & 0,8 & 0,7 & 0,0 & & 0,4 & 0,5 & 0,1 & & 0,7 & 0,7 & 0,2 & 11,1 \\
\hline \multirow[t]{2}{*}{ D9S1121 } & 9 & 6 & 5 & 6 & 3 & 2 & 1 & 0,33 & 4 & 7 & 3 & 7,23 & 8 & 7 & 1 & 1 \\
\hline & 0,5 & 0,4 & 1,0 & 61,0 & 0,7 & 0,5 & 0,0 & & 0,5 & 0,4 & 0,2 & 13,5 & 0,7 & 0,5 & 0,1 & \\
\hline \multirow[t]{2}{*}{ D9S1122 } & 0 & 0 & 0 & 0 & 8 & 4 & 7 & 3,81 & 6 & 1 & 5 & 2 & 5 & 4 & 0 & 5,28 \\
\hline & 0,5 & 0,5 & 1,0 & 61,0 & 0,6 & 0,7 & 0,2 & 15,7 & 0,5 & 0,7 & 0,1 & & 0,7 & 0,8 & 0,3 & 20,6 \\
\hline \multirow[t]{2}{*}{ D9S934 } & 0 & 9 & 0 & 0 & 1 & 5 & 9 & 2 & 9 & 8 & 8 & 9,47 & 0 & 0 & 8 & 4 \\
\hline & 0,6 & 0,5 & 1,0 & 61,0 & 0,6 & 0,7 & 0,3 & 19,5 & 0,6 & 0,6 & 0,5 & 28,1 & 0,8 & 0,7 & 0,0 & \\
\hline \multirow[t]{2}{*}{ D10S1435 } & 0 & 6 & 0 & 0 & 5 & 0 & 6 & 1 & 9 & 6 & 2 & 8 & 8 & 0 & 8 & 4,37 \\
\hline & 0,8 & 0,6 & 0,6 & 41,7 & 0,5 & 0,6 & 0,2 & 12,3 & 0,6 & 0,6 & 0,3 & 17,1 & 0,6 & 0,6 & 0,2 & 11,6 \\
\hline \multirow[t]{2}{*}{ D10S1248 } & 9 & 6 & 8 & 8 & 0 & 4 & 3 & 7 & 7 & 5 & 2 & 1 & 0 & 7 & 1 & 0 \\
\hline & 0,7 & 0,7 & 1,0 & 61,0 & 0,7 & 0,5 & 0,1 & & 0,5 & 0,6 & 0,0 & & 0,6 & 0,6 & 1,0 & 54,0 \\
\hline \multirow[t]{2}{*}{ D10S1426 } & 8 & 0 & 0 & 0 & 2 & 8 & 4 & 7,70 & 0 & 5 & 5 & 2,65 & 5 & 0 & 0 & 0 \\
\hline & 1,0 & 0,7 & 0,1 & 11,3 & 0,8 & 0,7 & 0,6 & 32,4 & 0,8 & 0,7 & 0,8 & 48,0 & 0,7 & 0,7 & 0,8 & 48,3 \\
\hline \multirow[t]{2}{*}{ D10S2470 } & 0 & 8 & 9 & 9 & 3 & 5 & 0 & 6 & 2 & 3 & 9 & 4 & 1 & 8 & 9 & 1 \\
\hline & & & & & 0,2 & 0,2 & 1,0 & 54,0 & 0,3 & 0,3 & 0,2 & 14,3 & 0,5 & 0,5 & 0,3 & 17,7 \\
\hline \multirow[t]{2}{*}{ D10S2327 } & & & & 0,00 & 8 & 6 & 0 & 0 & 9 & 9 & 7 & 3 & 8 & 9 & 3 & 0 \\
\hline & 0,8 & 0,6 & 1,0 & 61,0 & 0,6 & 0,7 & 0,6 & 32,5 & 0,5 & 0,6 & 0,4 & 26,1 & 0,7 & 0,6 & 0,8 & 47,3 \\
\hline \multirow[t]{2}{*}{ D11S2365 } & 3 & 8 & 0 & 0 & 5 & 6 & 0 & 3 & 3 & 8 & 8 & 7 & 4 & 6 & 8 & 7 \\
\hline & 0,3 & 0,6 & 0,0 & & 0,8 & 0,6 & 0,8 & 48,2 & 0,7 & 0,6 & 0,8 & 45,5 & 0,8 & 0,7 & 0,5 & 27,6 \\
\hline \multirow[t]{2}{*}{ D12S1300 } & 3 & 5 & 9 & 5,70 & 0 & 5 & 9 & 5 & 8 & 7 & 4 & 1 & 0 & 7 & 1 & 2 \\
\hline & 0,6 & 0,6 & 0,8 & 50,4 & 0,7 & 0,7 & 0,1 & & 0,7 & 0,6 & 0,4 & 25,8 & 0,7 & 0,6 & 0,2 & 14,2 \\
\hline \multirow[t]{2}{*}{ D12S395 } & 7 & 7 & 3 & 0 & 6 & 9 & 5 & 8,02 & 2 & 7 & 8 & 9 & 0 & 9 & 6 & 1 \\
\hline & 0,8 & 0,8 & 0,7 & 48,4 & 0,8 & 0,8 & 0,0 & & 0,7 & 0,7 & 0,3 & 19,1 & 0,7 & 0,6 & 0,9 & 50,7 \\
\hline D13S317 & 9 & 6 & 9 & 4 & 5 & 2 & 9 & 4,62 & 2 & 2 & 6 & 7 & 5 & 4 & 4 & 3 \\
\hline
\end{tabular}




\begin{tabular}{|c|c|c|c|c|c|c|c|c|c|c|c|c|c|c|c|c|}
\hline & 0,5 & 0,4 & 1,0 & 61,0 & 0,5 & 0,4 & 0,6 & 37,2 & 0,6 & 0,6 & 1,0 & 54,0 & 0,7 & 0,7 & 0,1 & \\
\hline \multirow[t]{2}{*}{ D13S1807 } & 6 & 7 & 0 & 0 & 5 & 5 & 9 & 1 & 5 & 0 & 0 & 0 & 0 & 0 & 7 & 9,24 \\
\hline & 0,7 & 0,7 & 0,7 & 45,8 & 0,7 & 0,7 & 0,9 & 48,4 & 0,5 & 0,7 & 0,0 & & 0,8 & 0,8 & 0,1 & \\
\hline \multirow[t]{2}{*}{ D13S800 } & 8 & 8 & 5 & 2 & 2 & 7 & 0 & 2 & 0 & 0 & 7 & 3,70 & 4 & 1 & 3 & 7,14 \\
\hline & 0,4 & 0,4 & 0,3 & 20,6 & 0,6 & 0,4 & 0,3 & 20,8 & 0,6 & 0,5 & 0,6 & 33,4 & 0,6 & 0,6 & 0,9 & 48,6 \\
\hline \multirow[t]{2}{*}{ D14S1434 } & 4 & 8 & 4 & 7 & 0 & 9 & 9 & 1 & 7 & 9 & 2 & 2 & 5 & 6 & 0 & 1 \\
\hline & 0,2 & 0,4 & 0,1 & & 0,6 & 0,5 & 1,0 & 54,0 & 0,7 & 0,6 & 0,1 & & 0,5 & 0,5 & 1,0 & 54,0 \\
\hline \multirow[t]{2}{*}{ D15S1515 } & 5 & 4 & 4 & 8,48 & 3 & 6 & 0 & 0 & 8 & 7 & 6 & 8,59 & 5 & 4 & 0 & 0 \\
\hline & 0,5 & 0,5 & 1,0 & 61,0 & 0,4 & 0,6 & 0,2 & 11,1 & 0,6 & 0,7 & 0,6 & 37,4 & 0,6 & 0,5 & 0,3 & 16,4 \\
\hline \multirow[t]{2}{*}{ D16S3253 } & 6 & 4 & 0 & 0 & 5 & 2 & 1 & 2 & 1 & 4 & 9 & 7 & 0 & 5 & 0 & 4 \\
\hline & 0,8 & 0,7 & 1,0 & 61,0 & 0,7 & 0,7 & 0,8 & 42,9 & 0,7 & 0,7 & 0,5 & 28,5 & 0,8 & 0,7 & 0,3 & 19,1 \\
\hline \multirow[t]{2}{*}{ D16S539 } & 9 & 6 & 0 & 0 & 0 & 7 & 0 & 8 & 2 & 0 & 3 & 8 & 3 & 7 & 5 & 5 \\
\hline & 0,7 & 0,6 & 0,5 & 32,8 & 0,6 & 0,7 & 0,5 & 28,1 & 0,7 & 0,7 & 0,9 & 53,0 & 0,6 & 0,6 & 0,1 & \\
\hline \multirow[t]{2}{*}{ GATA64B04P_17 } & 8 & 0 & 4 & 1 & 3 & 2 & 2 & 4 & 6 & 3 & 8 & 2 & 7 & 8 & 4 & 7,48 \\
\hline & 0,5 & 0,5 & 0,7 & 43,5 & 0,3 & 0,4 & 0,5 & 28,1 & 0,7 & 0,7 & 0,9 & 52,7 & 0,4 & 0,5 & 0,2 & 11,6 \\
\hline \multirow[t]{2}{*}{ GATA63G01_17 } & 6 & 8 & 1 & 0 & 5 & 1 & 2 & 9 & 5 & 3 & 8 & 2 & 7 & 5 & 2 & 4 \\
\hline & 0,6 & 0,7 & 0,5 & 35,5 & 0,3 & 0,3 & 1,0 & 54,0 & 0,6 & 0,6 & 0,3 & 16,2 & 0,4 & 0,5 & 0,2 & 14,0 \\
\hline \multirow[t]{2}{*}{ D17S1299 } & 7 & 2 & 8 & 1 & 8 & 9 & 0 & 0 & 1 & 6 & 0 & 0 & 7 & 1 & 6 & 3 \\
\hline & 0,5 & 0,7 & 0,0 & & 0,8 & 0,7 & 0,7 & 38,9 & 0,5 & 0,7 & 0,1 & 10,5 & 0,7 & 0,7 & 0,2 & 12,6 \\
\hline \multirow[t]{2}{*}{ D18S877 } & 6 & 2 & 2 & 1,30 & 5 & 2 & 2 & 3 & 9 & 4 & 9 & 2 & 5 & 3 & 3 & 3 \\
\hline & 0,4 & 0,5 & 1,0 & 61,0 & 0,5 & 0,6 & 0,1 & & 0,5 & 0,7 & 0,4 & 21,5 & 0,5 & 0,6 & 0,2 & 13,4 \\
\hline \multirow[t]{2}{*}{ D18S535 } & 4 & 0 & 0 & 0 & 0 & 4 & 5 & 8,31 & 6 & 2 & 0 & 4 & 5 & 2 & 5 & 5 \\
\hline & 0,5 & 0,6 & 1,0 & 61,0 & 0,5 & 0,5 & 0,7 & 41,4 & 0,6 & 0,6 & 0,7 & 40,6 & 0,5 & 0,6 & 0,6 & 34,1 \\
\hline \multirow[t]{2}{*}{ D19S559 } & 7 & 5 & 0 & 0 & 5 & 7 & 7 & 2 & 1 & 5 & 5 & 7 & 8 & 5 & 3 & 2 \\
\hline & 0,7 & 0,7 & 0,9 & 54,6 & 0,6 & 0,6 & 0,3 & 20,1 & 0,5 & 0,6 & 0,8 & 47,3 & 0,4 & 0,6 & 0,1 & \\
\hline \multirow[t]{2}{*}{ D20S482 } & 8 & 5 & 0 & 0 & 5 & 5 & 7 & 2 & 6 & 0 & 8 & 4 & 5 & 1 & 6 & 8,61 \\
\hline & 0,6 & 0,5 & 1,0 & 61,0 & 0,8 & 0,7 & 0,7 & 42,8 & 0,3 & 0,6 & 0,0 & & 0,6 & 0,5 & 1,0 & 54,0 \\
\hline D22S689 & 3 & 8 & 0 & 0 & 9 & 4 & 9 & 9 & 9 & 6 & 1 & 0,79 & 0 & 6 & 0 & 0 \\
\hline
\end{tabular}


Tabela 6A. Estimativas de Hardy-Weinberg para os loci de microssatélites do MHC para as populações Tyrió, Arara Laranjal, UrubuKaapor, Awá-Guajá. Onde HO= Heterozigose observada; HE= Heterozigose esperada; $p=$ p=valor; $p$-cor= p-valor corrigida para múltiplos testes.

\begin{tabular}{|c|c|c|c|c|c|c|c|c|c|c|c|c|c|c|c|c|}
\hline \multirow[t]{2}{*}{ POPUÇÕES } & \multicolumn{4}{|c|}{ Tiriyó } & \multicolumn{4}{|c|}{ Arara do Laranjal } & \multicolumn{4}{|c|}{ Urubu Kaapor } & \multicolumn{4}{|c|}{ Awa-Guajá } \\
\hline & & & & P- & & & & P- & & & & P- & & & & P- \\
\hline \multirow[t]{2}{*}{ Locus } & $\mathrm{HO}$ & $\mathrm{HE}$ & $\mathrm{P}$ & corr & $\mathrm{HO}$ & $\mathrm{HE}$ & $\mathrm{P}$ & corr & $\mathrm{HO}$ & $\mathrm{HE}$ & $\mathrm{P}$ & corr & $\mathrm{HO}$ & $\mathrm{HE}$ & $\mathrm{P}$ & corr \\
\hline & 0,8 & 0,7 & 0,6 & & 0,7 & 0,6 & 0,0 & & 0,4 & 0,3 & 0,6 & & 0,8 & 0,6 & 1,0 & \\
\hline \multirow[t]{2}{*}{ D6S2927 } & 8 & 1 & 8 & 4,73 & 5 & 9 & 6 & 0,44 & 5 & 7 & 4 & 4,45 & 2 & 8 & 0 & 7,00 \\
\hline & 0,3 & 0,5 & 0,1 & & 0,4 & 0,4 & 1,0 & & 0,2 & 0,4 & 0,1 & & 0,1 & 0,4 & 0,0 & \\
\hline \multirow[t]{2}{*}{ D6S2928 } & 6 & 5 & 8 & 1,28 & 4 & 7 & 0 & 7,00 & 5 & 5 & 1 & 0,80 & 0 & 8 & 2 & 0,15 \\
\hline & 0,6 & 0,7 & 1,0 & & 0,5 & 0,6 & 0,2 & & 0,8 & 0,6 & 0,1 & & 0,6 & 0,7 & 0,1 & \\
\hline \multirow[t]{2}{*}{ D6S265 } & 7 & 0 & 0 & 7,00 & 0 & 9 & 1 & 1,47 & 5 & 0 & 3 & 0,88 & 4 & 0 & 4 & 0,96 \\
\hline & 0,8 & 0,8 & 0,4 & & 0,7 & 0,7 & 0,2 & & 0,8 & 0,6 & 0,5 & & 0,6 & 0,7 & 0,2 & \\
\hline \multirow[t]{2}{*}{ D6S2972 } & 5 & 0 & 6 & 3,25 & 1 & 2 & 9 & 2,04 & 5 & 6 & 2 & 3,61 & 4 & 9 & 1 & 1,49 \\
\hline & 0,8 & 0,8 & 0,6 & & 0,8 & 0,8 & 0,8 & & 0,7 & 0,8 & 0,1 & & 0,4 & 0,7 & 0,0 & \\
\hline \multirow[t]{2}{*}{ HLABC } & 1 & 7 & 1 & 4,27 & 5 & 6 & 1 & 5,66 & 9 & 0 & 1 & 0,80 & 5 & 7 & 0 & 0,03 \\
\hline & 0,6 & 0,5 & 0,2 & & 0,4 & 0,5 & 0,1 & & 0,3 & 0,6 & 0,0 & & 0,5 & 0,5 & 1,0 & \\
\hline \multirow[t]{2}{*}{ MICA } & 7 & 4 & 7 & 1,92 & 0 & 6 & 4 & 1,00 & 5 & 7 & 0 & 0,02 & 0 & 2 & 0 & 7,00 \\
\hline & 0,1 & 0,3 & 0,0 & & 0,1 & 0,1 & 1,0 & & 0,2 & 0,3 & 0,4 & & & & & \\
\hline G51152 & 3 & 1 & 5 & 0,34 & 9 & 8 & 0 & 7,00 & 5 & 0 & 7 & 3,28 & mono & forfico & & \\
\hline
\end{tabular}

Tabela 6B. Estimativas de Hardy-Weinberg para os loci de microssatélites do MHC para as populações Parakanã, Assurini, Kayapó

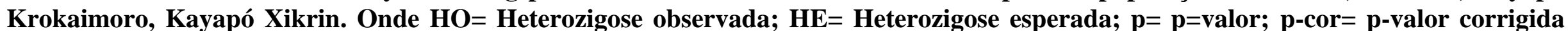
para múltiplos testes.

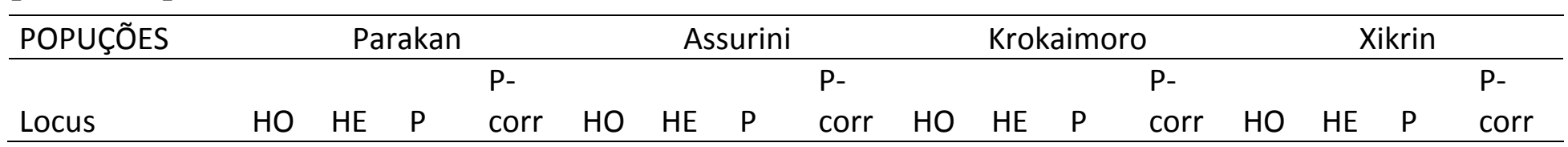




\begin{tabular}{lrrrlrrrllllllllll}
\hline & 0,6 & 0,6 & 1,0 & & 0,6 & 0,7 & 0,7 & & 0,8 & 0,7 & 0,9 & & 0,7 & 0,6 & 0,2 & \\
D6S2927 & 7 & 8 & 0 & 7,00 & 7 & 2 & 7 & 5,41 & 3 & 0 & 6 & 6,72 & 5 & 7 & 2 & 1,52 \\
& 0,3 & 0,5 & 0,4 & & 0,2 & 0,4 & 0,0 & & 0,6 & 0,5 & 0,3 & & 0,3 & 0,4 & 0,6 & \\
D6S2928 & 3 & 0 & 9 & 3,45 & 0 & 9 & 2 & 0,11 & 5 & 1 & 4 & 2,39 & 7 & 6 & 1 & 4,24 \\
& 0,8 & 0,6 & 0,1 & & 0,6 & 0,6 & 0,7 & & 0,7 & 0,7 & 0,3 & & 0,7 & 0,6 & 0,3 & \\
D6S265 & 9 & 3 & 8 & 1,27 & 3 & 9 & 2 & 5,07 & 2 & 4 & 7 & 2,59 & 0 & 4 & 0 & 2,12 \\
& 0,7 & 0,8 & 0,8 & & 0,7 & 0,8 & 0,3 & & 0,6 & 0,7 & 0,4 & & 0,6 & 0,7 & 0,1 & \\
D6S2972 & 8 & 2 & 2 & 5,72 & 9 & 2 & 6 & 2,50 & 7 & 5 & 2 & 2,96 & 5 & 0 & 3 & 0,93 \\
& 0,8 & 0,8 & 0,9 & & 0,8 & 0,8 & 0,3 & & 0,9 & 0,8 & 0,5 & & 0,8 & 0,8 & 0,0 & \\
HLABC & 9 & 1 & 7 & 6,81 & 0 & 8 & 4 & 2,40 & 4 & 3 & 4 & 3,76 & 4 & 3 & 2 & 0,12 \\
& 0,2 & 0,5 & 0,1 & & 0,3 & 0,5 & 0,0 & & 0,4 & 0,5 & 0,3 & & 0,5 & 0,4 & 1,0 & \\
MICA & 2 & 2 & 7 & 1,19 & 5 & 8 & 2 & 0,16 & 1 & 4 & 3 & 2,29 & 3 & 8 & 0 & 7,00 \\
& 0,5 & 0,4 & 1,0 & & 0,3 & 0,4 & 1,0 & & 0,5 & 0,4 & 0,6 & & 0,5 & 0,5 & 1,0 & \\
G51152 & 6 & 2 & 0 & 7,00 & 9 & 0 & 0 & 7,00 & 6 & 9 & 5 & 4,52 & 0 & 1 & 0 & 7,00 \\
\hline
\end{tabular}

Tabela 7A. Índices de diversidade por STR Genômico nas populações Africana, Europeia, Ameríndia e Belém. Onde He= Heterozigose e $\mathrm{K}=$ número de alelos.

\begin{tabular}{|c|c|c|c|c|c|c|c|c|c|c|c|c|c|c|c|}
\hline \multirow[b]{3}{*}{ Locus } & \multicolumn{3}{|c|}{ Africanos } & \multicolumn{4}{|c|}{ Europeus } & \multicolumn{3}{|c|}{ Amerindios } & \multicolumn{5}{|c|}{ Belém } \\
\hline & \multicolumn{2}{|c|}{ Theta } & \multicolumn{4}{|c|}{ Theta } & \multicolumn{4}{|c|}{ Theta } & \multicolumn{5}{|c|}{ Theta } \\
\hline & $\mathrm{He}$ & $\mathrm{H}$ & & $\mathrm{He}$ & $\mathrm{H}$ & k & & $\mathrm{He}$ & $\mathrm{H}$ & $\mathrm{k}$ & & $\mathrm{He}$ & $\mathrm{H}$ & $\mathrm{k}$ & \\
\hline & & & & 0,698 & & & & 0,563 & & & & 0,669 & & & \\
\hline \multirow[t]{2}{*}{ D1S551 } & 0,754 & 3,065 & 4 & 7 & 2,319 & & 5 & 6 & 1,291 & & 5 & 2 & 2,023 & & 6 \\
\hline & & & & 0,756 & & & & 0,807 & & & & 0,758 & & & \\
\hline \multirow[t]{2}{*}{ NAD1S_3 } & 0,8 & 4,000 & 6 & 8 & 3,111 & & 6 & 6 & 4,197 & & 7 & 9 & 3,148 & & 8 \\
\hline & 0,778 & & & 0,736 & & & & & & & & 0,791 & & & \\
\hline D1S1660 & 5 & 3,514 & 5 & 4 & 2,793 & & 5 & 0,717 & 2,533 & & 6 & 5 & 3,796 & & 7 \\
\hline GATA148G10P_ & 0,744 & & & 0,695 & & & & 0,669 & & & & 0,703 & & & \\
\hline 2 & 8 & 2,919 & 7 & 7 & 2,286 & & 5 & 7 & 2,028 & & 5 & 3 & 2,371 & & 7 \\
\hline
\end{tabular}




\begin{tabular}{|c|c|c|c|c|c|c|c|c|c|c|c|c|}
\hline & 0,832 & & & 0,734 & & & 0,798 & & & 0,772 & & \\
\hline \multirow[t]{2}{*}{ D2S1328 } & 2 & 4,959 & 6 & 6 & 2,768 & 7 & 2 & 3,956 & 7 & 1 & 3,388 & 7 \\
\hline & 0,760 & & & 0,789 & & & 0,571 & & & 0,711 & & \\
\hline \multirow[t]{2}{*}{ D2S1391 } & 9 & 3,183 & 5 & 8 & 3,757 & 7 & 1 & 1,331 & 7 & 4 & 2,465 & 9 \\
\hline & 0,659 & & & 0,622 & & & 0,276 & & & 0,589 & & \\
\hline \multirow[t]{2}{*}{ D2S2968 } & 8 & 1,939 & 3 & 5 & 1,649 & 6 & 4 & 0,000 & 5 & 5 & 1,436 & 7 \\
\hline & 0,600 & & & & & & 0,592 & & & 0,621 & & \\
\hline \multirow[t]{2}{*}{ GATA146B10_3 } & 5 & 1,503 & 3 & 0,691 & 2,237 & 5 & 1 & 1,452 & 6 & 6 & 1,643 & 7 \\
\hline & 0,774 & & & 0,796 & & & 0,750 & & & 0,771 & & \\
\hline \multirow[t]{2}{*}{ D3S3039 } & 9 & 3,442 & 5 & 8 & 3,920 & 6 & 8 & 3,013 & 7 & 6 & 3,378 & 7 \\
\hline & 0,844 & & & 0,831 & & & 0,675 & & & 0,781 & & \\
\hline \multirow[t]{2}{*}{ D3S1763 } & 2 & 5,419 & 6 & 9 & 4,950 & 6 & 2 & 2,079 & 6 & 3 & 3,573 & 8 \\
\hline & 0,779 & & & 0,725 & & & 0,728 & & & 0,759 & & \\
\hline \multirow[t]{2}{*}{ D4S3248 } & 3 & 3,531 & 6 & 5 & 2,642 & 6 & 8 & 2,687 & 6 & 4 & 3,157 & 8 \\
\hline & 0,789 & & & 0,782 & & & 0,722 & & & 0,820 & & \\
\hline \multirow[t]{2}{*}{ D4S2366 } & 9 & 3,759 & 6 & 2 & 3,592 & 6 & 3 & 2,601 & 7 & 4 & 4,569 & 7 \\
\hline & & & & 0,790 & & & & & & 0,731 & & \\
\hline \multirow[t]{2}{*}{ D4S2368 } & 0,75 & 3,000 & 4 & 7 & 3,778 & 6 & 0,684 & 2,164 & 7 & 4 & 2,723 & 6 \\
\hline & 0,802 & & & 0,846 & & & 0,667 & & & 0,809 & & \\
\hline \multirow[t]{2}{*}{ D5S816 } & 3 & 4,058 & 7 & 2 & 5,500 & 7 & 5 & 2,008 & 6 & 4 & 4,247 & 7 \\
\hline & & & & 0,799 & & & 0,727 & & & 0,827 & & \\
\hline \multirow[t]{2}{*}{ D5S2500 } & 0,9 & 9,000 & 8 & 2 & 3,979 & 8 & 1 & 2,664 & 7 & 5 & 4,798 & 9 \\
\hline & 0,767 & & & & & & 0,744 & & & 0,692 & & \\
\hline \multirow[t]{2}{*}{ GATA112F02P_6 } & 8 & 3,307 & 7 & 0,779 & 3,524 & 5 & 6 & 2,916 & 8 & 4 & 2,251 & 10 \\
\hline & 0,818 & & & 0,792 & & & 0,790 & & & 0,779 & & \\
\hline \multirow[t]{2}{*}{ D6S474 } & 4 & 4,506 & 5 & 8 & 3,827 & 6 & 3 & 3,768 & 6 & 4 & 3,532 & 7 \\
\hline & 0,669 & & & 0,779 & & & 0,717 & & & & & \\
\hline D6S1040 & 3 & 2,024 & 5 & 3 & 3,532 & 5 & 7 & 2,542 & 6 & 0,734 & 2,760 & 7 \\
\hline D7S2846 & 0,722 & 2,609 & 4 & 0,728 & 2,679 & 5 & 0,774 & 3,429 & 7 & 0,742 & 2,881 & 6 \\
\hline
\end{tabular}




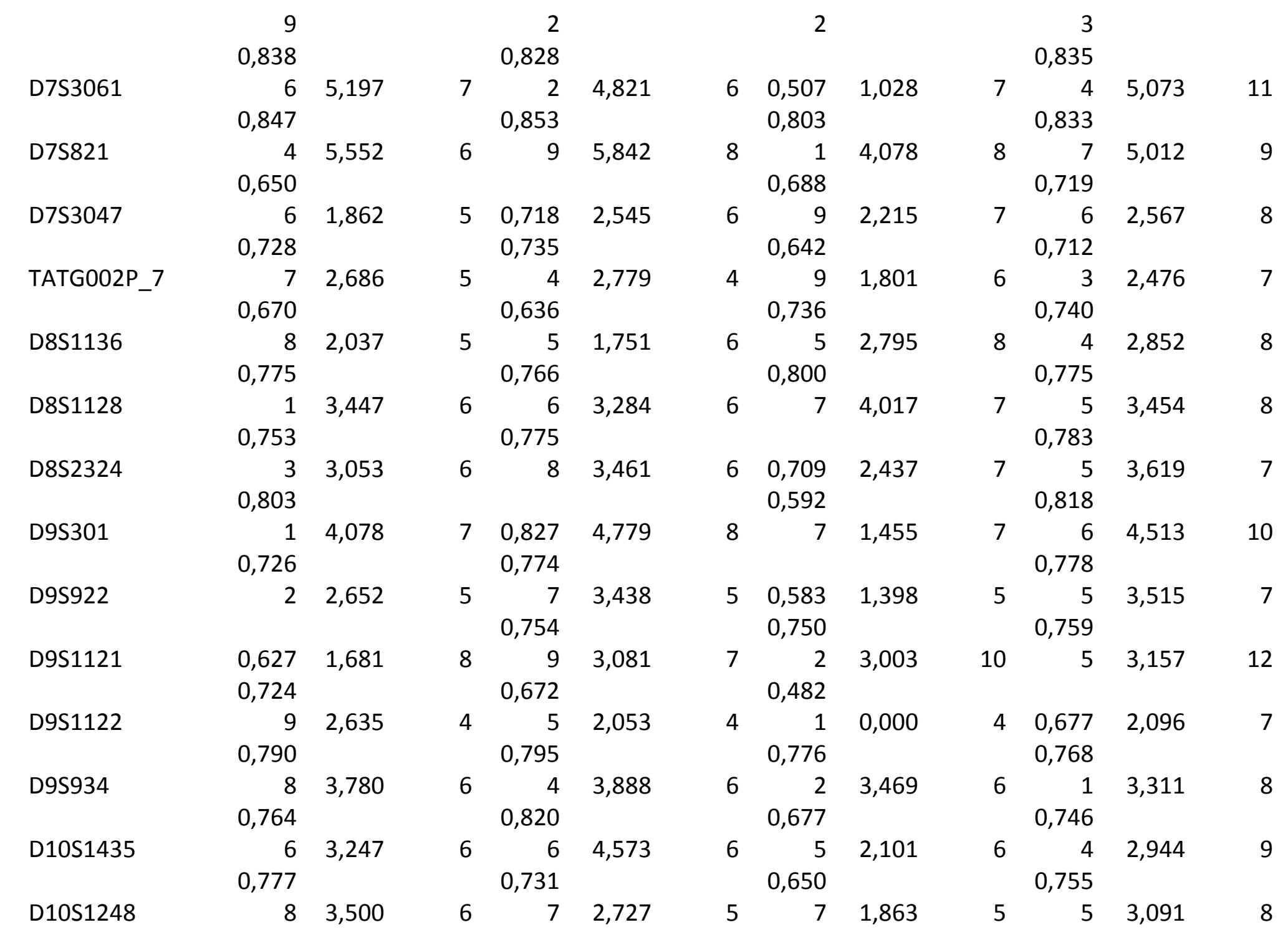




\begin{tabular}{|c|c|c|c|c|c|c|c|c|c|c|c|c|}
\hline & 0,641 & & & 0,758 & & & 0,668 & & & 0,720 & & \\
\hline \multirow[t]{2}{*}{ D10S1426 } & 3 & 1,788 & 4 & 4 & 3,139 & 5 & 9 & 2,020 & 5 & 6 & 2,579 & \\
\hline & 0,804 & & & 0,771 & & & 0,784 & & & 0,800 & & \\
\hline \multirow[t]{2}{*}{ D10S2470 } & 2 & 4,108 & 7 & 7 & 3,380 & 7 & 1 & 3,632 & 7 & 3 & 4,008 & \\
\hline & 0,731 & & & & & & 0,362 & & & 0,636 & & \\
\hline \multirow[t]{2}{*}{ D10S2327 } & 6 & 2,726 & 5 & 0,604 & 1,525 & 5 & 4 & 0,000 & 6 & 1 & 1,748 & \\
\hline & 0,637 & & & 0,626 & & & 0,723 & & & 0,678 & & \\
\hline \multirow[t]{2}{*}{ D11S2365 } & 6 & 1,759 & 3 & 9 & 1,680 & 5 & 9 & 2,622 & 5 & 7 & 2,112 & 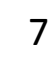 \\
\hline & 0,757 & & & 0,671 & & & 0,717 & & & 0,720 & & \\
\hline \multirow[t]{2}{*}{ D12S1300 } & 3 & 3,119 & 7 & 3 & 2,042 & 5 & 4 & 2,539 & 6 & 4 & 2,576 & \\
\hline & 0,694 & & & 0,778 & & & 0,753 & & & 0,767 & & \\
\hline \multirow[t]{2}{*}{ D12S395 } & 7 & 2,276 & 5 & 2 & 3,508 & 5 & 3 & 3,053 & 7 & 5 & 3,302 & 9 \\
\hline & 0,539 & & & 0,787 & & & & & & 0,812 & & \\
\hline \multirow[t]{2}{*}{ D13S317 } & 7 & 1,172 & 3 & 2 & 3,699 & 6 & 0,797 & 3,925 & 9 & 5 & 4,333 & \\
\hline & 0,756 & & & 0,774 & & & 0,625 & & & 0,757 & & \\
\hline \multirow[t]{2}{*}{ D13S1807 } & 3 & 3,104 & 5 & 7 & 3,439 & 5 & 4 & 1,670 & 6 & 5 & 3,124 & \\
\hline & 0,728 & & & 0,718 & & & 0,754 & & & 0,770 & & \\
\hline \multirow[t]{2}{*}{ D13S800 } & 7 & 2,686 & 5 & 9 & 2,558 & 4 & 5 & 3,073 & 7 & 2 & 3,352 & 9 \\
\hline & 0,673 & & & 0,700 & & & 0,536 & & & 0,698 & & \\
\hline \multirow[t]{2}{*}{ D14S1434 } & 6 & 2,063 & 4 & 9 & 2,343 & 5 & 2 & 1,156 & 5 & 9 & 2,321 & \\
\hline & 0,816 & & & 0,753 & & & 0,679 & & & 0,760 & & \\
\hline \multirow[t]{2}{*}{ D15S1515 } & 1 & 4,438 & 6 & 7 & 3,060 & 6 & 3 & 2,119 & 7 & 5 & 3,176 & 0 \\
\hline & 0,728 & & & 0,731 & & & 0,643 & & & 0,721 & & \\
\hline \multirow[t]{2}{*}{ D16S3253 } & 7 & 2,686 & 6 & 5 & 2,724 & 6 & 1 & 1,802 & 7 & 9 & 2,596 & \\
\hline & 0,793 & & & & & & 0,753 & & & 0,796 & & \\
\hline \multirow[t]{2}{*}{ D16S539 } & 9 & 3,851 & 6 & 0,777 & 3,484 & 7 & 1 & 3,050 & 5 & 4 & 3,912 & \\
\hline & 0,625 & & & 0,760 & & & 0,723 & & & 0,737 & & \\
\hline GATA64B04P_17 & 3 & 1,669 & 5 & 7 & 3,180 & 7 & 3 & 2,614 & 6 & 1 & 2,804 & \\
\hline GATA63G01_17 & 0,624 & 1,664 & 5 & 0,671 & 2,039 & 5 & 0,604 & 1,528 & 5 & 0,727 & 2,665 & \\
\hline
\end{tabular}




\begin{tabular}{lrrrrrrrrrrrrr} 
& 6 & & & & & & 4 & & & 1 & \\
& 0,714 & & & 0,484 & & & 0,564 & & & 0,652 & \\
D17S1299 & 3 & 2,500 & 4 & 3 & 0,000 & 4 & 3 & 1,295 & 6 & 2 & 1,875 & 9 \\
& 0,770 & & & 0,682 & & & 0,722 & & & 0,711 & & \\
D18S877 & 1 & 3,350 & 7 & 9 & 2,153 & 5 & 4 & 2,602 & 7 & 1 & 2,461 & 7 \\
& 0,732 & & & 0,785 & & & 0,715 & & & 0,781 & & \\
D18S535 & 8 & 2,743 & 5 & 1 & 3,654 & 6 & 6 & 2,516 & 7 & 9 & 3,585 & 8 \\
& 0,793 & & & 0,745 & & & 0,670 & & & 0,759 & & \\
D19S559 & 5 & 3,842 & 6 & 6 & 2,932 & 6 & 2 & 2,032 & 6 & 9 & 3,166 & 6 \\
D20S482 & 0,756 & & & 0,687 & & & 0,699 & & & 0,699 & & \\
& 6 & 3,109 & 7 & 6 & 2,201 & 6 & 6 & 2,329 & 5 & 7 & 2,330 & 9 \\
D22S689 & 0,742 & & & 0,803 & & & 0,709 & & & 0,732 & & \\
\hline & 5 & 2,884 & 5 & 9 & 4,098 & 6 & 1 & 2,438 & 8 & 2 & 2,734 & 10 \\
Média & 0,742 & 3,197 & 5,444 & 0,743 & & 5,759 & 0,677 & & 6,407 & 0,744 & 7,777 \\
\hline
\end{tabular}

Tabela 7B. Índices de diversidade por STR do MHC nas populações Africana, Europeia, Ameríndia e Belém. Onde He= Heterozigose e K= número de alelos.

\begin{tabular}{|c|c|c|c|c|c|c|c|c|c|c|c|c|c|c|c|c|}
\hline \multirow[b]{2}{*}{ Locus } & \multirow[b]{2}{*}{$\mathrm{He}$} & \multicolumn{3}{|l|}{ Africanos } & \multicolumn{3}{|c|}{ Europeus } & \multicolumn{4}{|c|}{ Amerindios } & \multicolumn{5}{|c|}{ Belém } \\
\hline & & Theta $\mathrm{H}$ & $\mathrm{k}$ & & $\mathrm{He}$ & ThetaH & $\mathrm{k}$ & & $\mathrm{He}$ & ThetaH & $\mathrm{k}$ & & $\mathrm{He}$ & ThetaH & $k$ & \\
\hline D6S292 & & & & & & & & & & & & & & & & \\
\hline 7 & 0,64368 & 1,81 & & 5 & 0,68846 & 2,21 & & 5 & 0,68355 & 2,16 & & 5 & 0,7303 & 2,71 & & 6 \\
\hline D6S292 & & & & & & & & & & & & & 0,6419 & & & \\
\hline 8 & 0,65977 & 1,94 & & 5 & 0,68922 & 2,22 & & 5 & 0,50599 & 1,02 & & 3 & 1 & 1,79 & & 5 \\
\hline & & & & & & & & & & & & & 0,7855 & & & \\
\hline$D 6 S 265$ & 0,73231 & 2,74 & & 7 & 0,79387 & 3,85 & & 9 & 0,70617 & 2,40 & & 6 & 8 & 3,66 & & 11 \\
\hline D6S297 & & & & & & & & & & & & & 0,8677 & & & \\
\hline 2 & 0,87356 & 6,91 & & 10 & 0,86258 & 6,28 & & 8 & 0,79819 & 3,96 & & 9 & 9 & 6,56 & & 15 \\
\hline
\end{tabular}




\begin{tabular}{|c|c|c|c|c|c|c|c|c|c|c|c|c|}
\hline$H L A B C-$ & & & & & & & & & & 0,9338 & & \\
\hline$C A$ & 0,91534 & 10,81 & 12 & 0,94286 & 16,50 & 15 & 0,88257 & 7,52 & 16 & 8 & 14,12 & 20 \\
\hline & & & & & & & & & & 0,7797 & & \\
\hline$M I C A$ & 0,73545 & 2,78 & 5 & 0,74564 & 2,93 & 7 & 0,59923 & 1,50 & 4 & 7 & 3,54 & 6 \\
\hline & & & & & & & & & & 0,7199 & & \\
\hline G51152 & 0,75132 & 3,02 & 5 & 0,73751 & 2,81 & 6 & 0,43569 & 0,77 & 3 & 3 & 2,57 & 9 \\
\hline & & & & & & & & & & 0,7798 & 4,9948 & 10,2857 \\
\hline Média & 0,75878 & 4,28631 & 7,00000 & 0,78002 & 5,25672 & 7,85714 & 0,65877 & 2,76078 & 6,57143 & 8 & 6 & 1 \\
\hline
\end{tabular}

